University of San Diego

Digital USD

1989

\title{
Organizational Change in Action: A Qualitative Case Study of USAir's Acquisition of Pacific Southwest Airlines
}

Joan A. Miszak EdD

University of San Diego

Follow this and additional works at: https://digital.sandiego.edu/dissertations

Part of the Leadership Studies Commons

\section{Digital USD Citation}

Miszak, Joan A. EdD, "Organizational Change in Action: A Qualitative Case Study of USAir's Acquisition of Pacific Southwest Airlines" (1989). Dissertations. 527.

https://digital.sandiego.edu/dissertations/527

This Dissertation: Open Access is brought to you for free and open access by the Theses and Dissertations at Digital USD. It has been accepted for inclusion in Dissertations by an authorized administrator of Digital USD. For more information, please contact digital@sandiego.edu. 


\author{
ORGANIZATIONAL CHANGE IN ACTION: \\ A QUALITATIVE CASE STUDY OF USAIR'S \\ ACQUISITION OF PACIFIC SOUTHWEST AIRLINES
}

by

Joan A. Miszak

A dissertation submitted in partial fulfillment of the requirements for the degree of

Doctor of Education

University of San Diego

1989

Dissertation Committee

Joseph Rost, Ph.D., Director

William Foster, Ed.D.

Edward Kujawa, Jr., Ph.D. 
Copyright 1989

by

Joan A. Miszak

All Rights Reserved 


\author{
ABSTRACT \\ ORGANIZATIONAL CHANGE IN ACTION: \\ A QUALITATIVE CASE STUDY OF USAIR'S \\ ACQUISITION OF PACIFIC SOUTHWEST AIRLINES
}

MISZAK, JOAN A., Ed.D. University of San Diego, 1989

$313 \mathrm{pp}$.

Director: Joseph C. Rost, Ph.D.

Five dominant theories of organizational change have emerged from the literature. Each of these models expressly expand on a singular and specific paradigm of how change can be viewed within organizations. The models of change are the micro-personal-therapeutic, meso-rational-managerial, meso-systems-organic, macro-cultural-symbolic and macro-political-economic. While the contemporary literature on organizational change has done much to further our understanding about the future of organizational change, very few works provide us with case study examples of organizational change in action. Missing is an understanding of what facilitators of change actually do in the process of change.

The present study sought to provide a descriptive analysis of how one organizational change took shape in one major American corporation. Throughout an in-depth description of the acquisition of Pacific Southwest Airlines by USAir, five deliberate and planned actions resulted which were part of a strategic change plan designed to facilitate 


\begin{abstract}
a smooth transition from one organization (PSA) to another (USAir). These actions were the internal mechanisms used for articulating the change, the external mechanisms used for articulating the change, the programmatic processes used during the change, the impacting leader actions and the grass roots movement. The actions were thoroughly described and analyzed in relation to the dominant change models. Trends from these actions revealed that specific paradigms emerged.

The author concludes that a more multi-dimensional, rather than a singular, paradigm of change permeated the acquisition period. Although all models were represented, the political-economic and the systems-organic models dominated.
\end{abstract}


DEDICATION

To the employees of Pacific Southwest Airlines, who made aviation history by making flying fun! 
$\underline{\text { Page }}$

DEDICATION . . . . . . . . . . . . . . . . . $i i$ TABLE OF CONTENTS ...................... . iii LIST OF FIGURES . . . . . . . . . . . . . . . . . vi vi STATEMENT OF THE ISSUE . . . . . . . . . . . . . . . 1

Introduction . . . . . . . . . . . . . . 1

The Issue . . . . . . . . . . . . . 5

Purpose of the study . . . . . . . . . . . 8

Definition of Terms ................ 9

Dissertation Organization . . . . . . . . . 11

REVIEW OF LITERATURE . . . . . . . . . . . . 12

Leadership and Change Link . . . . . . . . . 12

Change and Competitive Advantage . . . . . . . 13

Mergers and Acquisitions . . . . . . . . . 16

Dimensions of Change . . . . . . . . . . . 21

Change Strategies . . . . . . . . . . . . 24

Planned Organizational Change and Adaptation . . . 28

The Micro-Personal-Therapeutic Model . . . . . 29

The Meso-Rational-Managerial Model . . . . . 33

The Meso-Systems-Organic Model . . . . . . . 35

The Macro-Cultural-Symbolic Model . . . . . 36

The Macro-Political-Economic Model . . . . . 37

Conclusion . . . . . . . . . . . . . 39

RESEARCH DESIGN AND METHODOLOGY . . . . . . . . . . 42

Design . . . . . . . . . . . . . . 4 42

Methodology . . . . . . . . . . . . . 45 
Page

The Ethnographic Approach . . . . . . . . 46

Ethnographic Research Procedures . . . . . . 47

The Historical Case Study Approach . . . . . . 48

Change Events . . . . . . . . . . . . 49

The Internal Mechanisms for Articulating Change - 49

The External Mechanisms for Articulating Change . 50

The Programmatic Processes . . . . . . . 50

The Impacting Leader Actions . . . . . . . 51

The Grass Roots Movement . . . . . . . . 51

Participants . . . . . . . . . . . . . 52

Site Selection . . . . . . . . . . . . 52

On-Site Observation . . . . . . . . . . . 53

Data Gathering . . . . . . . . . . . 53

Data Analysis . . . . . . . . . . . . . 54

Descriptive Analysis . . . . . . . . . . 55

THE HISTORY OF PACIFIC SOUTHWEST AIRLINES . • . . . . . 56

THE ACQUISITION OF PSA BY USAIR: CHANGE IN ACTION . • 85

Communication of the Change . . . . . . . . 86

The Change Strategy . . . . . . . . . . 89

Internal Mechanisms for Articulating Change . . 92

External Mechanisms for Articulating Change . . 129

The Programmatic Processes . . . . . . . . 174

The Basic Beliefs ............ . 176

The Needs Analysis . . . . . . . . . 179

The Programmatic Process Content . . . . . 185

The Impacting Leader Actions . . . . . . . . 209 
A Look at Russell Ray . . . . . . . . 210

Development and Execution of Change Strategy . 219 Actions Taken to Facilitate the Change . . . 221

The Grass Roots Movement . . . . . . . . . 237

SUMMARY, CONCLUSIONS AND DISCUSSION . . . . . . . . 261

Summary and Conclusions . . . . . . . . . 262

Internal Mechanisms for Articulating Change . . 262

External Mechanisms for Articulating Change . . 268

The Programmatic Processes . . . . . . . . 275

The Impacting Leader Actions . . . . . . . . 283

The Grass Roots Movement . . . . . . . . 287

Overall Conclusions . . . . . . . . . . . 292

strengths . . . . . . . . . . . . 302

Weaknesses .... . . . . . . . . . 304

Future Research ................ 306

Concluding Remarks . . . . . . . . . . . 307

REFERENCES . . . . . . . . . . . . . . 309 


\section{IIST OF FIGURES}

Figure

Page

1. Dimensions of planned organizational change . - 43

2. Letter from PSA's chairman, Paul Barkley, announcing the merger . . . . . . . . 87

3. Announcement of the first intervention with USAir Chairman Ed Colodny . . . . . . . 94

4. The first release of the new PSA USAir

Merger Update . . . . . . . . . . . 96

5. Concerns expressed by employees regarding

the status of their departments within

the company . . . . . . . . . . . . . 98

6. More assertive questions from the employees

of PSA . . . . . . . . . . . . . . . 99

7. Interest groups emerge . . . . . . . . 101

8. Pilot union approves merger . . . . . . . 104

9. Persuasive communication based on the belief that the merger was positive . . . . . 106

10. Ed Colodny's letter to USAir employees . . . 109

11. An emerging political focus as voting groups align in favor of the merger . . . . . . . 111

12. Another work group joins the pro merger coalition ................ 113

13. Federal court dismisses Teamster lawsuit . . 117

14. The Teamsters appealed the lawsuit and continued the dispute with PSA . . . . . . 119

vi 
15. Summary of PSA proposals from March 17

through April 10. 1987 . . . . . . . . 122

16. Summary of the PSA-Teamster Agreement . . . . 125

17. Letter from Ed Colodny to PSA employees welcoming them to USAir . . . . . . . 127

18. Letter from PSA Chairman Paul Barkley to new USAir employees . . . . . . . . . . . 128

19. An example of the emotional language used by the San Diego press . . . . . . . . . 132

20. Article featuring an interview with USAir's Edwin Colodny . . . . . . . . . . 136

21. The cultural-symbolic power of the PSA smile . 138

22. Will USAir keep PSA's identity? . . . . . 140

23. Pilots Association reaches agreement to accept the merger . . . . . . . . . . 143

24. Government regulators approve merger plan . . . 144

25. Mid-merger turbulence initiatea by Teamsters . 146

26. The PSA smile... . . . . . . . . 147

27. Teamster opposition builds . . . . . . . 150

28. Teamsters sue PSA in U.S. District Court . . . 152

29. TWA proposed to buy USAir . . . . . . . . 154

30. USAir, Piedmont agreed to merge . . . . . . 156

31. Shareholder's meeting at the Westgate Hotel in San Diego, California . . . . . . . 158

32. Association of Flight Attendants seeks election at PSA . . . . . . . . . . 161 
33. Union-PSA talks stalled . . . . . . . . 163

34. Unhappy union members want PSA contract offer put to vote . . . . . . . . . 165

35. PSA Teamster-represented employees protest lack of progress in contract negotiations . . 166

36. Union accord clears way for purchase of PSA . 168

37. PSA Teamsters vote to support USAir merger . . . . . . . . . . . . 170

38. PSA ticket agents share counter with USAir . . . . . . . . . . . 172

39. PSA planes may keep on smiling . . . . . . 173

40. The four change quadrants . . . . . . . . 189

41. Practical application questions as they relate to the quadrants of change . . . . . . . 191

42. Cover of PSA's communication strategy brochure .................. . 214

43. Systems-organic and political-economic models of change are predominant when viewing the internal mechanisms for articulating change . . 269 44. Cultural-symbolic and political-economic models of change are predominant when viewing the external mechanisms for articulating change .. . . . . . . . . . . . 276

45. Systems-organic and personal-therapeutic models of change are predominant when viewing the programmatic processes . . . . 282 
46. Cultural-symbolic and systems-organic models of change are dominant from viewing the impacting leader actions . . . . . . . 288

47. Personal-therapeutic and political-economic models of change are predominant from the viewing of the grass roots movement . . . . 293

48. The extent to which the case study exemplifies and operationalizes the five primary models of organizational change . . . . . . . . 296 
CHAPTER I

STATEMENT OF THE ISSUE

Introduction

In every aspect of modern life and all over the world today, we are being bombarded with change. The vastness and complexity of all that is changing around us often creates difficulties among our nations, our communities, our businesses, our families and ourselves. Change on the current corporate stage is common and constant. The organizational actors are weakened and ineffective if their scripts are memorized, as if to imply that their lines will remain the same. The organizational actors who can master the art of improvisation and extemporaneous thought are those that become strengthened by flexibility and effective by accepting the notion that their environment is fluid and dynamic. Furthermore, the organizational actors must also be intertwined with their audience in order to create a domain which both sees and produces change.

From an organizational perspective, the idea of seeing, creating and facilitating change is one of the most difficult, perplexing and challenging opportunities faced by organizational theorists, managers and leaders. This challenge has often led to increasingly unfavorable 
outcomes. Corporate America is in a change crisis. Kanter (1983) articulated a thought-provoking reflection of the condition of today's business community by asserting that:
Business organizations are facing a change more extensive, more far-reaching in its implications, and more fundamental in transforming quality than anything since the "modern" industrial system took shape in the years between, roughly, 1890 and 1920. . . In this second transforming era, between 1960 and 1990, American industry will need to learn to operate in a wholly new mode. (p. 16)

There seems to be a kind of compulsion on the part of the American business community to bring about fundamental and long-lasting change. The exerted pressure to change has come from forces such as domestic and international competition, deregulation, reregulation, realigned social orders, new technologies, and more. As a result, there has been vast restructuring of organizations through mergers and acquisitions.

Ward (1987) has estimated that more than half of the Fortune 1,000 companies in the United States have experienced substantial reorganization activity in the 1980s. During 1986 alone, an astonishing 4,000 organizations were engaged in this change fervor at the cost of some $\$ 200$ billion.

In concert with the overwhelming amount of change 
that impacts every human being today, Peters and Waterman (1982) and Ruch and Goodman (1983) believe that ineffective leadership, traditional management practices, the MBA programs in business schools and ineffective education in our elementary and secondary schools are at the root of the change crisis. With changing worldwide and domestic business needs, changing roles and values, changing external influences such as unionization and the media, there indeed is a fundamental need to keenly focus on all dimensions of organizational change, while simultaneously modifying our thinking on the subject. Burns (1978) explained that:

The leadership process must be defined, in short, as carrying through from the decision-making stages to the points of concrete changes in people's lives, attitudes, behaviors, and institutions. Even the sweep of this process is not enough, however, for we must include another dimension: time. Attitude and behavior can change for a certain period; as in a war, popular fads and emotional political movements change only to revert later. Real change means a continuing interaction of attitudes, behaviors, and institutions, monitored by alteration in individual and collective hierarchies of values. (p. 414) Planning for change within an organization is the specific dimension where the crux of the change issue lies. Organizations often engage in the planning process 
without regard to the fact that the plan itself may need to be altered. Activity is generated around preserving the plan instead of changing the plan further due to changes in the internal and external environment. Almost of greater importance is the fact that plans are made with regard to how to get to the end result, void of how to facilitate change in the very process of achieving the result. Some of these notions of planned organizational change are detailed in the literature on organizational development (Alderfer, 1977; Argyris \& Schon, 1978; Friedlander \& Braun, 1974; Katz \& Kahn, 1976). The problem is that the people in organizations have not yet sufficiently incorporated these and other change theories into how they manage and lead.

Burns (1984) has argued that the process of planning for structural change is in essence the ultimate moral test of decision making leadership which is inspired by goals and values and which is intent on achieving real change. He suggested that this process of planning is the leader's most potent weapon.

It is a weapon in that a well-conceived plan, along with available planning technology, supplies leaders with an estimate of the human, material and intellectual resources necessary to draw up and drive through a plan for substantial social change. Planning is designed to anticipate and to counter the myriad factors that impair the line of decision and 
action between the policy-making of planning leaders and real change in the daily lives of great numbers of people. (p. 419)

If Burns is correct in suggesting that the planning process for organizational change is in fact a weapon for real change, it should not come as a shock to recognize that our difficulty in implementing change is hindered by our inability to cultivate effective change processes. If, as the preceding discussion suggests, there is a change crisis facing American business and the world today, it is vital that we as scholars, practitioners, managers and potential leaders confront the problems associated with narrow views or single models of change and develop a new understanding of this constant, fluid, on-going, dynamic, always present and evolutionary process which moves individuals and organizations.

The Issue

Few companies today are immune to the threat of a merger or acquisition. This is particularly true in the airline industry. As deregulation took shape in the $1970 \mathrm{~s}$ and the 1980s, airlines were faced with competitive pressures as they had never experienced before. Wrought with bankruptcies, abrupt acquisitions, mergers and hostile takeovers, the airline industry became highly vulnerable. Competing corporations became vultures for market share and in doing so reduced fares, cut costs, trimmed wages, conserved fuel, reacted to pressures from 
government and labor unions, pulled in and out of cities, established operating hubs in major cities, cross utilized employees to gain productivity; and service to the consumer in the process, plummeted. Some airlines weakened and as a result were gobbled up by stronger airlines. The surge of airline mergers began. Republic Airlines took over Hughes AirWest and then Northwest Airlines took over Republic Airlines. Texas Air Corporation purchased People's Express and then Continental Airlines and finally the failing Eastern Airlines. American Airlines acquired Air Cal and most recently USAir purchased the troubled Pacific Southwest Airlines.

The present condition of the American airlines industry is anything but stable; it is an aggressively competitive environment in which only the financially strong will survive. In order to continue to survive, change is inevitable. Moreover, for those that were consumed, such as Pacific Southwest Airlines by USAir, the process of how change took place becomes critical and can be a predictor to future survivability.

While the contemporary literature on change in organizations has done much to foster our understanding about the nature of change, very few works provide us with real case study examples of substantial processes or organizational change in action. Writers and scholars have described key facets of change which theoretically 
and conceptually frame issues of the change process. However, these works and studies do little to demonstrate the application of a given theory, model or concept through the use of actual examples. This is a serious void in the literature on change because without case study examples it is difficult to distinguish what determines a successful change from one that is not successful. Moreover, the existence of only a few deep, ethnographic studies in the literature makes it extremely difficult for both scholars and practitioners to apply how real, intended change can effectively be implemented. Missing is a broad understanding of what is actually done in the process of planned organizational change. In essence, the literature on change has not yet fully changed to address the very means by which ends are accomplished.

While there is some research that looks at both the leadership abilities and the change agent abilities of high level executives using the case study method (Bennis \& Nanus, 1985; Levinson \& Rosenthal, 1984), only a few of the examples in these studies touch upon organizational change in a multidimensional and meaningful fashion. This is also a compounded problem because it is difficult for researchers to gain access into organizations before, during and after a significant structural change has taken place. Therefore, it is crucial that scholars seeking to broaden their understanding of the change process study 
deeply situations in which researchers have implanted themselves into the very fiber of the organization for a duration of time which accurately portrays the change cycle.

\section{Purpose of the Study}

The purpose of this study is to provide an in-depth description of how the acquisition of PSA by USAir progressed from the point just before the acquisition was publicly announced until the merger legally and officially closed. The examination will predominantly focus on the changes that took place at PSA during this eight month slice of time. To effectively accomplish this purpose the following research questions will be addressed in this case study:

1. What specific actions were taken by PSA to deliberately facilitate the change, who initiated these actions, and why?

2. To what extent does this case exemplify and operationalize the five primary models of organizational change?

3. To what extent was the implementation of this organizational change skewed toward one single paradigm of change or to a more multidimensional paradigm of change?

4. What conclusions can be drawn so that scholars and practitioners of organizational change can gain from the thick description of this case study and its relationship to the predominant change models? 
It is the position of this researcher that if we are going to increase and deepen our understanding about planned organizational change, we must examine specific change processes in specific contexts.

Definition of Terms

The following terms will be referred to and used throughout the course of this research.

Acquisition: The legal and financial process in which one party or organization purchases the majority of stock, thereby becoming the majority stockholder of another entity.

Change: The alteration of one state to another. What is to be made different could be attitudes, beliefs, behaviors, interaction patterns of roles or groups, or organizations (adapted from Goodman et al., 1982).

Intervention: Planned programmatic activities which take place during organizational change. These activities are designed to improve the organization's functioning by enabling members of the organization to better manage their environments in a productive fashion.

Leadership: A sustained, developmental process in which a leader seeks to heighten the moral aspirations of followers by producing real intended change, by accomplishing the mutual goals of both leader and led, by articulating a vision which moves followers to purposeful action, by shaping values, by mobilizing resources to meet mutual needs, by capitalizing on competition and conflict, 
by building strong organizational cultures and by establishing caring relationships with followers that will optimally inspire the emergence of other leaders.

Merger: A process of blending two business entities into one; the integration of policy, practice, procedure, image, beliefs, attitudes, methods of operating, language, style, culture, equipment, resources, and organization. It is a process of blending two business entities into one.

Organization Symbolism: Those aspects of an organization that its members use to reveal or make comprehensible the unconscious feelings, images, and values that are inherent in that organization.

Planned Organizational Change: A set of activities included in a formal process intentionally designed to change the attitudes and behaviors of individuals and/or groups in an organization as well as organizational structures and processes (adapted from Goodman et al., $1982)$

Ritual: Relatively elaborate, dramatic, planned sets of activities that consolidate forms of cultural expressions into one event and which are carried out through social interactions, usually to berefit an audience (adapted from Trice, 1984).

Symbol: Any object, act, event, quality or relation that serves as a vehicle for conveying meaning (adapted from Trice, 1984). 
Dissertation Organization

In describing how the concept of organizational change is operationalized by one company, the second chapter of this investigation presents a review of literature surrounding the major components of the concept.

The research design and methodology for the study is outlined in Chapter Three.

Chapter Four describes the history of Pacific Southwest Airlines. This chapter provides the background of the organization which is necessary for understanding the growth and development of PSA.

Chapter Five presenis the thick description of five comprehensive change actions and how those actions relate to appropriate models of change. Some of the researcher's observations and interpretations of the data collected are also included in this chapter. Additionally, Chapter Five presents an array of figures that complement and go into even more detail, the data gathered through observation. Finally, Chapter Six presents a summary of the study and the researchers' conclusions regarding the degree to which the subject of this investigation reflects the models of change. The summary and conclusions in this chapter are followed by a discussion of the strengths and weaknesses of the study and the researcher's concluding remarks. 
CHAPTER II

REVIEW OF LITERATURE

Leadership and Change Link

In his description of transformational leadership, Burns (1978) was quite explicit about the significant link between change and leadership. He advocated that the process of leadership is identifying expressed and unexpressed wants among followers, bringing them to higher levels of consciousness regarding their needs, and transforming their needs into hopes and expectations. The dynamic of transforming leadership is to initiate and govern change. Burns (1978) concluded that:

The essence of leadership in any polity is the recognition of real need, the uncovering and exploiting of contradictions among values and between values and practice, the realigning of values, the reorganization of institutions where necessary, and governance of change. The leader's fundamental act is to induce people to be aware or conscious of what they feel--to feel their true needs so strongly, to define their values so meaningfully, that they can be moved to purposeful action. (pp. 43-44)

Transforming leadership includes the process of producing real, intended change. When the change process 
is triggered or initiated by a leader for some purpose, and when it is substantial and transforming in the end and when the change recognizes the mutual goals of leaders and followers, the important link between organizational change and leadership is significantly strengthened. Transitioning to a more expansive focus on the organizational change dynamic, it is clear that we must study change more fully if we are ever to consider its enormous impact and influence on the overall subject of leadership. Baldridge \& Deal (1983) stated:

The most stable fact about organizations . . . is that they change. Change can be a major overhaul or a cosmetic afterthought, a substantive renovation or a lively ritual, a response to a crisis or an opportunity for excitement and adventure. But whether changes are minute or monumental in scope, the constant in our modern society is that organizations are always shifting, changing, transforming, and realigning. (p. 1-2)

Change and Competitive Advantage

The increasingly turbulent environment of the last ten years has worked to focus executives' attentions on the need to aggressively seek out and exploit competitive advantages as the means to organizational survival. In today's rapidly changing world economy; however, traditional competitive mechanisms such as pricing, product and technological advantage are becoming less 
effective as competitors meet or copy every corporate initiative.

The decade of the $1980 \mathrm{~s}$ will no doubt be remembered as the time of transition in business (Thorrow, 1981). For the economy as a whole, pressures for transition have grown as indicated by Ulrich (1987) in the following data: - The federal budget deficit has ballooned from $\$ 75$ billion in 1971 to over $\$ 220$ billion in 1986 (U.S. Commerce Department).

- Merchandise trade balance imbalance has worsened from $\$-25$ billion in 1981 to $\$-140$ billion in 1986 (U.S. Office of Management and Budget).

- Direct foreign investment in the U.S. has grown from $\$ 82.9$ billion in 1980 to $\$ 182.9$ billion in 1985 (U.S. Department of Commercel.

- Business failures per 10,000 concerns has risen from 42 per year in 1980 to 190 in 1985 (Statistical Abstract of the United States, 1986).

- National income originating in manufacturing has continued to drop to a low of $22 \%$ in 1984 while the gap between employees in service related (74\%) and goods related (26\%) has increased to an all time high (Statistical Abstract of the United States, 1986). - Total value of takeovers (mergers and acquisitions) has increased from $\$ 30$ billion in 1980 to over $\$ 170$ billion in 1986 .

These national and economic conditions expose 
significant and dramatic change throughout the United States economy through the first half of the $1980 \mathrm{~s}$ (Abernathy, 1981; Lund \& Hansen, 1986; Reich, 1983). These underlying economic conditions have exposed many industries to enormous transitions.

According to Ulrich (1987):

Bank failures have risen from 10 per year in 1980 to over 140 in 1986. Over 200 airlines have been merged or sold since 1978 to respond to the competitive pressures of deregulation; deregulation has equally affected trucking, telecommunications, and oil industries. Even agriculture has undergone dramatic change with the total number of farmers being reduced from 1.6 million to 1.3 million with further reductions expected. (p. 170)

These industry transitions have translated to many firms dramatically transforming their businesses. The turbulent decade of the 1980 s may be characterized by two central themes. First, change: Rapid and dramatic change has transformed the economy, traditional industry structures, and firms. Global competition, technological growth, federal legislation and policies, and increased service economy represent national illustrations of these quick and fundamental changes. Second, competitiveness: Response to these rapid and dynamic changes has forced United states organizations to focus on gaining and maintaining a competitive advantage. 
Mergers and Acquisitions

The literature on cases of organizational change, particularly in the area of mergers and acquisitions is quite small. Thee have been, however, some valuable writings on the subject which can add insight into both the philosophical as well as practical views of organizational change.

In 1986 Wells Fargo merged with Crocker National Corporation. Quinn (1987) described the \$1.07-billion deal as the largest in United States history and one of the few that will be financially justifiable in the long run. To achieve its goals, Wells Fargo fired 1,650 employees as soon as the merger became effective, and the manner in which Wells handled its employees negatively affected morale. The shift in attitude and commitment by employees led to a period of productivity decline so significant that management reacted with post chaos fix attempts such as communication sessions and employee involvement strategies.

Along the same line, according to an anonymous writer (1987), when Midwest Commerce acquired the \$65-milition First National Bank of Goshen, there were several severe problems of community rivalries and differences in the bank cultures. Shortly thereafter, NBD Bancorp Inc. acquired Midwest Commerce. This merger was said to have been handled well as employees were kept as informed as was possible, and there were no displacements as a result 
of the merger.

Some of the common patterns of behavior and communication in corporate mergers and acquisitions are cited in a paper written by Bastien (1987). A study was conducted of common patterns of communications and behavior in mergers and acquisitions. Data were collected via interviews with 21 managers in the acquired company in three separate acquisitions. The data were then aggregated to construct three cases that described some common patterns of behavior and communication in mergers and acquisitions. Three central issues became evident. First, personal uncertainty was pervasive and should have been ameliorated through communication management. Second, the individual and social processes of coping with this uncertainty involved sudden switches between opposites rather than gradual change from one state to another.

Last, culture change and culture shock were definitionally present in mergers and acquisitions and these factors should be managed.

Further on the communication theme of organizational change in a merger or acquisition, Bertrand (1987) contended that despite the increase in corporate mergers and acquisitions, many companies do not communicate well with key audiences as the agreement unfolds, or even after it is complete. However, silence causes speculation, which results in the buyer's and seller's credibility 
suffering. Customers, investors, and employees may defect, and stock prices, productivity, and sales may decline. Companies can communicate about what is happening by using a full spectrum of corporate communications vehicles, from advertising to employee publications. Communications can be used to:

1. Establish a new corporate identity of two merged companies.

2. Position companies for an acquisition or merger.

3. Obtain investor support for an offering.

4. Tell employees and customers what is being done to protect them.

Some mergers result in staff trimmings, plant closings or consolidations, and large scale relocation of employees. Sometimes companies acquire other companies, encounter difficulties in integrating them and spin off parts of the acquisition. Some divest portions of themselves to avoid a takeover. Therefore, according to Gerard (1986) successful divestitures and mergers demand that five issues be faced and resolved:

1. Employees should be informed fully as soon as possible about any change.

2. Careful consideration must be given to what specialized talent is needed and what skills are no longer useful to the company.

3. Severance and relocation policies need to be designed specially to fit the individual situation. 
4. Location decisions should balance considerations of real estate, operations, and people.

5. Major operations of the business must continue while merger or divestiture discussions are taking place. All of these issues need to be addressed during the negotiations leading up to a merger.

Clearly the concept of merger mania is enveloping the corporate world, affecting all employees. Often the stakes are very high in negotiations that top management must keep secret to protect public shareholder value. Unfortunately, as believed by Howard (1986), the people who have the most at stake in a hostile takeover or merger are usually the last to know. However, confidentiality, secrecy, and abrupt announcements take a heavy toll on employees. Thus, there is an urgent need for a broader scope of information and substance in employee communication in three areas:

1. A greater emphasis on the employee's role in profitability and the enhancement of shareholder value.

2. A greater awareness of how the merger "environment affects the economy.

3. A greater understanding of basic issues like pensions and health insurance plans. Once these factors are accomplished, employees will better , understand what is happening and will feel much less stressed.

It appears that the impact of corporate restructuring 
on employees is often overlooked. Merrell (1986) suggested that the organization will suffer during a restructuring as long as workers are uncertain about their future. The lack of information and failure to communicate with employees during restructuring intensifies feelings of uncertainty. The results of uncertainty are insecurity and a loss of motivation. - Several elements can be integrated into restructuring plans to cope with personnel issues. These elements include precision and clarity of planning and communication and consistency in personnel policies. Termination benefits siould be fair, and intentions should not be revealed until management is sure of them. Management should put the organization to work immediately on a challenging task to give employees a sense of direction. It is also helpful if the restructuring includes promotions to improve motivation.

An interesting perspective offered by Price (1985) pointed out that sometimes mergers do not go through and that under these circumstances, attention still needs to be paid to the change process. Merger or acquisition - negotiations that fail cause many problems, especially for the employees of the companies involved. Companies thus should include in their strategy a plan to minimize these negative effects on personnel. A company does not have to be actually merged or acquired for the workforce to be disrupted and the company's operating effectiveness 
- damaged. It is important for corporate managers to anticipate the negative impact of a failed acquisition or merger and respond to problems in a timely, action-oriented manner. Upon initiation of takeover discussions, management should selectively communicate to employees what is occurring. In the event that the deal fails, management should reassure personnel and reaffirm corporate goals and objectives, using this period to gain a stronger leadership role and to restore their credibility.

\section{Dimensions of Change}

Not all change should be studied as a result of a merger or acquisition. Change can also be viewed and studied as it is compared to some specific dimension.

A study conducted by Bloomquist (1986) investigated the relationship between school staff job satisfaction or morale and number of organizational changes occurring at the Portsmouth (New Hampshire) Junior High School. The issues under examination included homogeneous vs. -heterogeneous groupings, class length, school within a school or teaming, department chairs vs. house coordinators, a flexible or modular scheduling as factors that might affect staff morale, communication, and student learning. Using an evaluation design, the research team undertook a descriptive case study of the match between school philosophy and the scheduling practices related to teacher teaming and student ability 
grouping. Data were collected from all school practices, along with self-report measures of staff emotional exhaustion, negative attitudes toward students, and feelings of personal accomplishment. The findings suggested that low levels of emotional exhaustion and high feelings of personal accomplishment correlate strongly with providing adequate time for people to reach time management objectives and planning objectives. Researchers concluded that scheduling should include staff input to reflect people's need for effective planning time.

A view of the process of change can certainly be integrated to that which is becoming new or modernized. As in the case of technological advancements, change is propelling at an enormously rapid rate.

Automated office technologies, such as office automation systems, management information systems, teleconferencing, message systems, and robotics, are providing momentum for the trend towards the "paperless office" by allowing new means of carrying out office tasks and aiding in the management of time, data, and messages. According to Licata (1984) the success of these systems depends on how effectively they are introduced into the office. Such efforts as solicitation of employee input are needed to overcome resistance to change and encourage acceptance of the new technology. The potential impact of a new technology should be studied both at the micro level 
lof the individual and his/her performance changes, job satisfaction, stress level, and attitude toward the job and the technology), and at the macro level (including changes in organizational efficiency, departmental interactions, quality of work life, and changing patterns of work). Potential impacts can be either positive or negative. Positive impacts include improved intellectual performance, increased work discipline, reduction in wasted time, increased efficiency, increased timing and control, increased visibility, increased quantity and quality of work, increased flexibility of time and location of work, and improved quality of work life. 'Negative impacts include boredom, problems of dependency and stress, feelings of isolation, decrease in organizational loyalty, decrease in quantity and quality of social interactions, and decrease in the quality of work life. The task of management is to investigate the changes that are occurring throughout the organization in order to aid workers in integrating the new technology into their work lives.

Another study relating to new technology conducted by Soukup and Boone (1983) tested the premise that people cope with ambiguity in change periods in particular ways within an organizational context, negotiating for understanding and choice through the manipulation of power, ideology and technology.

The study focused on the implementation of a 
satellite communications network in local Catholic Church offices and on staff members' positive and negative perceptions of ambiguity that resulted from the new system. Results showed that ambiguity was reduced within the offices through the use of power, ideology, and technology. From an external perspective, ambiguity was used in a positive way to open up possibilities for the creative use of technology, for renegotiating the goals of the Catholic Communications Network, and for realigning the power structure of the communication system of the Church.

\section{Change Strategies}

What infiltrates the literature are change strategies which can be used in order to effectively implement, manage, facilitate, study and view change in organizations. Widespread are the advocates of one strategy or another; yet many have important insights, practices and contributions to make with regard to the massive subject of change.

In his paper on the construction of relationships from which to change organizations, Lowman (1980) argued that organizational consultants should attend to several issues when consulting as change agents for organizations. He suggested that the client will have explicit ideas about the need for help and implicit expectations and fears about the role of the consultant. The consultant must probe, understand, and often change the client's 
preconceptions and expectations about consulting. In establishing a consultant-client relationship, the consultant needs to be aware of possible defensive reactions, including denial, immediate action demands, and control attempts. Three primary tasks faced in the preliminary phases of consultation are:

1. Establishing a trust relationship.

2. Making an assessment of the client system.

3. Sharing a futuristic image of the organization. Ideally, organizational consultants should be trained in settings in which they receive intensive supervised experiences in consultation, multiple opportunities to increase self-awareness and individual growth, and exposure to the diversity of organizational types and phenomena. It is only through this process that effective change agents can emerge.

A step-by-step strategy for change was developed by Kotter and schlesinger (1979) from their belief that organizational change frequently encounters some form of human resistance. They prescribe that managers must be aware of the most common reasons that people resist change:

1. Desire not to lose something of value.

2. Misunderstanding of the change and its implications.

3. Belief that the change does not make sense for the organization. 
4. Low tolerance for change.

Managers can help overcome people's resistance to organizational change by:

1. Education and communication.

2. Participation and involvement.

3. Facilitation and support.

4. Negotiation and agreement.

5. Manipulation and co-optation.

6. Explicit and implicit coercion.

Managers can improve their chances of successfully implementing organizational change by:

1. Analyzing situations and problems.

2. Analyzing change factors.

3. Selecting change strategies based on analysis.

4. Monitoring the implementation process.

A strategy to involve the employee before, during and after an organizational change is one which is commonplace in the literature. Benashel (1981) stated that there are three important considerations to take before implementing large organizational changes which affect employees' lives:

1. Time should be provided to help separate the psychological impact of the change from its practical consequences on the lives of employees.

2. Information should be shared immediately with all affected employees.

3. Trust and respect should be expressed in words 
and deeds for the individuals involved by being open about changes from the start.

Although providing time, trust, and information when implementing changes can make things more difficult for the managers at first, in the long run, the effort will help make changes run more smoothly and effectively.

Because better communication and involvement are frequently cited as an effective change strategy in organizations, it would seem that models which aid in improving communication and involvement would be sought with vigor. This is not always the case, as suggested by Graham (1981), when he wrote about the fact that better communication and involvement programs may not be desired goals in some organizations, and that there may be some people who would benefit from poor communication. He stated:

There are benefits to poor communication, which include:

1. minimizing the effect of poor planning, 2 . reducing questions, 3. usefulness as a technique for getting and maintaining power, 4. helping to avoid confrontation and anxiety, and 5. helping to minimize opposition and criticism. It is suggested that the effects of the benefits of poor communication should be considered as a part of any Management Science process. It must be remembered that if there is poor communication in an organization, there are a set of 
reasons for it. The Management Science process may generate conflict, as people will be affected by a model. Those people should be involved in its construction, which ultimately involves communication. (p. 80)

Planned Organizational Change and Adaptation In their explanation of change, Goodman and associates (1982) described organizational change as categorically planned change and adaptation. Planned organizational change is geared toward a progression of activities and processes which change individuals, groups, and organization structure and process. The most important word is planned. The fact that the change is planned means that there are intervention strategies that are used in order to effect the change.

Adaptation is a concern which modifies an organization, or parts of the organization, so that adjustment to the environment takes place. Child (1972) strongly advocated that managers play a significant role in this process by influencing how their organizations adapt to the environment.

However, Goodman (1982) stated that "the distinction between planned organizational change and adaptation is arbitrary. The two concepts are not independent. Planned organizational change can increase adaptability, and adaptability can lead to planned organizational change" (p. 4). 
Like two sides of the same coin, organizational change is planned and/or a process of adaptation. The two concepts are interwoven. Goodman (1982) further concluded:

Planned organizational change deals with the basis of change; adaptation deals with the conditions or sources of change. Planned organizational change focuses primarily on change within the organization, but the adaptation literature focuses primarily on populations of organizations and on organization-environment interfaces, and on changes within an organization that are environmentally dictated. (p. 4)

In essence, planned change emphasizes the process of actually creating change. It is devoted to methods and techniques. Adaptation emphasizes the processual nature of change. It is devoted to theorizing about change processes and outcomes, whether the changes were planned or not.

\section{The Micro-Personal-Therapeutic Model}

The micro-personal-therapeutic model emphasizes the change that originates at the individual or personal level. The model focuses on both the internalization of change and the interpersonal level. It suggests that meaningful or real organizational change results only when individuals believe and value the change. Foster (1986) described this model as follows: 
Since the organization is made up of individuals, each acting according to some role or script, to change the organization first requires that the individuals themselves are changed in some fashion. This model includes such topics of concern as self-concept, personality, integration, conflict management, communication processes, trust development, personality fixations, values clarifications, and so on. (p. 152)

The complex nature of the micro-personal-therapeutic model is clear. This model gets to the root of change and becoming changed. It deals with the psychological implications of change, and it emphasizes the notion of dealing with and shifting personal views and ways of thinking from old to new constructed realities.

Lewin's (1951) work on the individual's impact on organizational change is most worthy. He described three stages in the process of personal change: unfreezing, changing, and refreezing. In the first stage of unfreezing, the interpersonal intervention penetrates the current belief system and how one views a particular issue or event as it relates to one's self image. Unfreezing reveals that a person's constructed reality is different from another form of constructed reality. Like an ice-cube, a given constructed reality melts. Examples of this melting or unfreezing would be when an alcoholic admits to being an alcoholic, or when a nonpracticing 
Christian suddenly becomes reborn, or when an employee stops resisting a change such as an acquisition by letting go of the old situation and the identity that went with it.

The refreezing process is the new constructed reality. It is the time in which receptivity and acceptance occur.

Bridges (1988) suggested that there is a difference between change and transition. He differentiated that: Change happens when something starts or stops, or when something that used to happen in one way starts happening in another. It happens at a particular time, or in several stages at different times. Organizational change is structural, economic, technological or demographic. Transition, on the other hand, is a three-part psychological process that extends over a long period of time and cannot be planned or managed by the same rational formula that works with change. (p. 25)

It is believed that there are three phases that people go through.

First, similar to unfreezing, people have to let go of the old situation and of the old identity that went with it. No one can begin a new role or have a new purpose if that person has not let go of the old role or purpose first. Whether people are moved or promoted, outplaced or reassigned, they have to let go of who they 
were and where they have been if they are to make a successful transition. A great deal of what we call resistance to change is really difficulty with the first phase of transition.

Second, people have to go through the neutral zone between their old reality and a new reality that may still be very unclear. In this highly ambiguous time, everything feels unreal. It is a time of loss and confusion, a time when hope alternates with despair and new ideas alternate with a sense of meaninglessness, a time when the best one can do sometimes is to go through the motions. But it is also the time when the real reorientation that is at the heart of transition is taking place.

Third, and similar to freezing, people have to make a new beginning, a beginning that is much more than the relatively simple new start required in a change. The new beginning may involve developing new competencies, establishing new relationships, becoming comfortable with new policies and procedures, constructing new plans for the future and learning to think in accordance with new purposes and priorities.

It is this three-phase reorientation process from an old to a new way of being that organizational leaders usually overlook when change is planned. Bridges further states:

The planners work hard to show why the changes are 
good; they build coalitions to support them; they work out PERT charts to schedule them; they see that the necessary funds are appropriated to pay for them; they assign managerial responsibility for implementing them. And they mumble darkly about selfishness, stupidity and treachery when the people affected by the changes slow these changes down, making the planners spend more money than they had forecast. In the end, these same people may even abort the very changes on which the organization's future depends. (p. 26)

Bridges (1986) concluded that with the unfreezing states comes disengagement, disidentification and disenchantment. With the change phase comes disorientation, disintegration and discovery. With the refreezing stages comes receptivity, openness, and acceptance.

\section{The Meso-Rational-Managerial Model}

The meso-rational-managerial model emphasizes the rational actors in an organization who have been convinced by logical facts and evidence that a change is necessary. The change can then be implemented or facilitated by a step-by-step strategy that moves in succession, over time, and is validated with data and evidence along the way.

Cole (1982) pointed out that there is a systematic way to view planned change. It is a highly proceduralized process which is based upon evidence. It is prescriptive 
and research based.

An example of a systematic procedure can be viewed from Havelock's (1973) work in which he used the acronym DAETEIM to discuss the types of resources available to the change agent and their significance to the process of change.

Diagnosis is step one. This step involves developing resources appropriate to diagnosis such as key informants and other information sources pertinent to the change issue.

Awareness is step two. This step builds and maintains resource awareness such as networking, developing resource files and other knowledge-seeking alternatives.

Evaluation is step three, which involves becoming specific about the problem or solution like one might discover in an observation period or a pretest.

Trial is step four. This step is the pilot of a procedure to predict its outcome.

Evaluation is step five. This step looks at what has occurred during the trial. In essence, it could be a post test mechanism.

Installation is step six. This encompasses the process of implementation.

Maintenance is step seven, which involves any follow-up requirements.

This mechanical example of the 
meso-rational-managerial model serves as a clear picture of a process of change where checklists, steps, logical paths and little diversion and innovation prevail.

\section{The Meso-Systems-Organic Model}

Perhaps Foster (1986) best summarized the emphasis of the meso-systems-organic model.

The two major assumptions made in this model are both encompassed by the model's description. The organic aspect assumes that organizations are similar to organisms--they grow, develop, change and die. The systems aspect assumes that organizations are systems composed of interrelated and interdependent subsystems. These twin assumptions have led to the largest movement to implement change in organizations: organizational development. (p. 154) Friedlander and Braun (1974) covered a wide range of organizational development literature during 1973 and 1974. During those years organizational development writers focused on the methods organizational development people used to facilitate change and the development of people. The methods involved people, technology, organizational processes and structures (Friedlander \& Braun, 1974, p. 314). The emphasis was on technostructural approaches such as job design and job enlargement, and on human approaches, such as survey feedback and interventions.

Alderfer (1977) indicated that the practice of 
organizational development was no longer ingrained in just the business arena. The practice of organizational development has spread across both public and private sectors. Additionally, there are new and emerging forms of survey feedback techniques being used in all arenas. These practices are contributing to more sophisticated theories on change.

Organizational development and, more specifically, the meso-systems-organic model link conceptual framework and strategy. The goal is to correct or renew the organization. In the process, people within the organization learn and interact through a set of interventions usually triggered by a consultant. The process involves change on the interpersonal level, the subsystem level and the overall organizational level.

The Macro-Cultural-Symbolic Model

Rost (1982) suggested that transformational leaders, those who have been able to effect real, intended, substantive change in their organizations and the lives of their followers, have the ability to create visions and engage followers' imaginations in pursuit of them. Transformational leadership encompasses motivating people to action and converting followers into leaders and change agents. For this reason, the recognition of symbols, rituals, language and other cultural aspects as an integral part of organizational change is becoming more evident. 
Bolman and Deal (1984) contended that the cultural approach to organizational analysis and organizational change must be viewed by scholars for a more complete picture. They maintained that an effective organization operates through widely accepted, interactive, articulated and lived myths, symbols and rituals.

If we study organizations and organizational change, we must examine how we think and talk about them, for our system of talking and what we are talking about are intertwined (Pondy, 1978). Because the structure of language has constraints that limit our thinking (Feyerabend, 1975; Whorff, 1979), those linguistic limits will also shape our level of knowing. Foster (1986) stated:

In summary, symbols, rituals, and the like are expressions that help us to recognize the social world in which we live. We gain an understanding of and appreciation for our particular culture only by comparing it with other cultures; we recognize our sameness, in a sense, only through recognizing difference. The idea of culture becomes a means for thinking about how a social grouping becomes cohesive and develops similar values and world views. (p. 162) The Macro-Political-Economic Model

The macro-political-economic model is a clear lens which is comprehensive, relationship-oriented, and includes both the internal and external environment. Zald 
(1970) provided a framework which includes four quadrants or components of political economy. They are:

1. Polity and environment structure and process.

2. Polity and internal structure and process.

3. Economy and environment structure and process.

4. Economy and internal structure and process.

This framework represents a valuable contribution in that it stresses the relevance of how the political ecoromy affects organizations, and it emphasizes that both the internal and external environment have economic and political fiber.

The model itself sees organizations as political systems with political actors. The actors have their own interests and stakes and stands. Coalitions are formed within a political environment. An organization changes as a result of shifts in rewards, supply and demand, interest groups, negotiation and bargaining.

Zald (1968) further pointed out that the political economy approach focuses on "proximal internal and external determinants of change. It links change to organizational structure and goals as opposed to leaping from internal problems to leadership decision; thus, it spells out a complete causal and contingent chain" (p. 222).

Transformational leaders are political actors who use power to "realize the purposes of both leaders and followers" (Burns, 1978, p. 18). Thus, it is important to 
note that transformational leaders are individuals with broad sociopolitical perspectives (Levinson \& Rosenthal, $1984)$ that use political savvy and wisdom as positive forces in the process of effecting significant organizational change.

\section{Conclusion}

Real, intended change as suggested by Burns (1978) and planned organizational change as suggested by Goodman (1982) are deep and highly philosophical constructs yet, as the literature implies, it is not without practical value. It is philosophical in that it is often intellectually far reaching. It is practical in that leaders effect significant institutional change by addressing the real wants and needs of followers. The literature also shows that organizational change transcends individual disciplines. Illustrating this point as it relates to the broader issue of leadership, Burns (1984) recognized that "the problem is that no field of study calls for a more difficult and daring crossing of disciplinary borders than does the study of leadership, and no field suffers more from narrow specialization" ( $p$. 6). Thus, by its substantial link to leadership, real, intended change is multidisciplinary in nature and embodies anthropology, communications, linguistics, organizational development, organizational theory, philosophy, political science, psychology and sociology. Collectively, these fields provide us with multiple lenses 
so we can approach the study of change from a broader variety of perspectives. Also, by viewing similarities and differences in organizational change across disciplines, this multidisciplinary approach accounts for the vastness and complexity of change. Thus, inherent within organizational change is a kind of universal quality that confirms the theoretical validity of the construct and points out the practical framework for application in the real world.

The literature assists us greatly by categorically describing change as planned and adaptive (Goodman et al., 1982). Since planned change spotlights the methods and techniques for actually creating change, and since adaptation deals with the theory of change processes and outcomes, whether the change was planned or not, we as scholars cannot segregate these categorically described concepts. This thinking automatically helps us broaden our view of change.

The most basic understanding of change is that it is an integration of models. Bolman and Deal (1984), Cole (1982), Foster (1986), Friedlander and Braun (1974), Lewin (1951), Zald (1970) and others have all pointed out that organizational change models, although distinct in many ways, must be integrated in some fashion to order to fully see change.

It is clear that a sound theoretical base has been established. It is also clear that a practical set of 
techniques and strategies have emerged which espouse the way change theories should be applied. The meaningful connection of theory in action, however, has not been fully addressed in the literature.

While research to date has brought us a long way toward understanding that planned organizational change and adaptation are interrelated, the actual number of case studies describing how change takes place within an organization is minimal at best. Missing from the literature are examples of how change happens in specific settings. What is needed are actual case studies that illustrate how these models and theoretical constructs are operationalized. To that end, this investigation will seek to build upon an already growing body of literature by examining the theory of organizational change in action. 


\section{CHAPTER III}

\section{RESEARCH DESIGN AND METHODOLOGY}

\section{Design}

In order to fulfill the purpose of this study and to sufficiently answer the associated research questions, this researcher described the change process involved in the acquisition of PSA by USAir. To do this, 25 cells have been built, each providing a different view of the change event. Like a photographer, several different lenses were used to take a picture of the same scene. These different looks allowed the researcher to adequately glean learnings about this change as they related to the change models. As Figure 1 illustrates, a story can be told in each cell, comparing and contrasting the relationship of the model of change to the specific change action taken.

The primary dimensions of planned organizational change are:

1. The accomplishment of micro-personal-therapeutic actions which focus on individualistic and personal levels of change.

2. The accomplishment of meso-rational-managerial actions which deal with the prescriptive, step-by-step plan for change. 
Dimensions of Planned Organizational Change

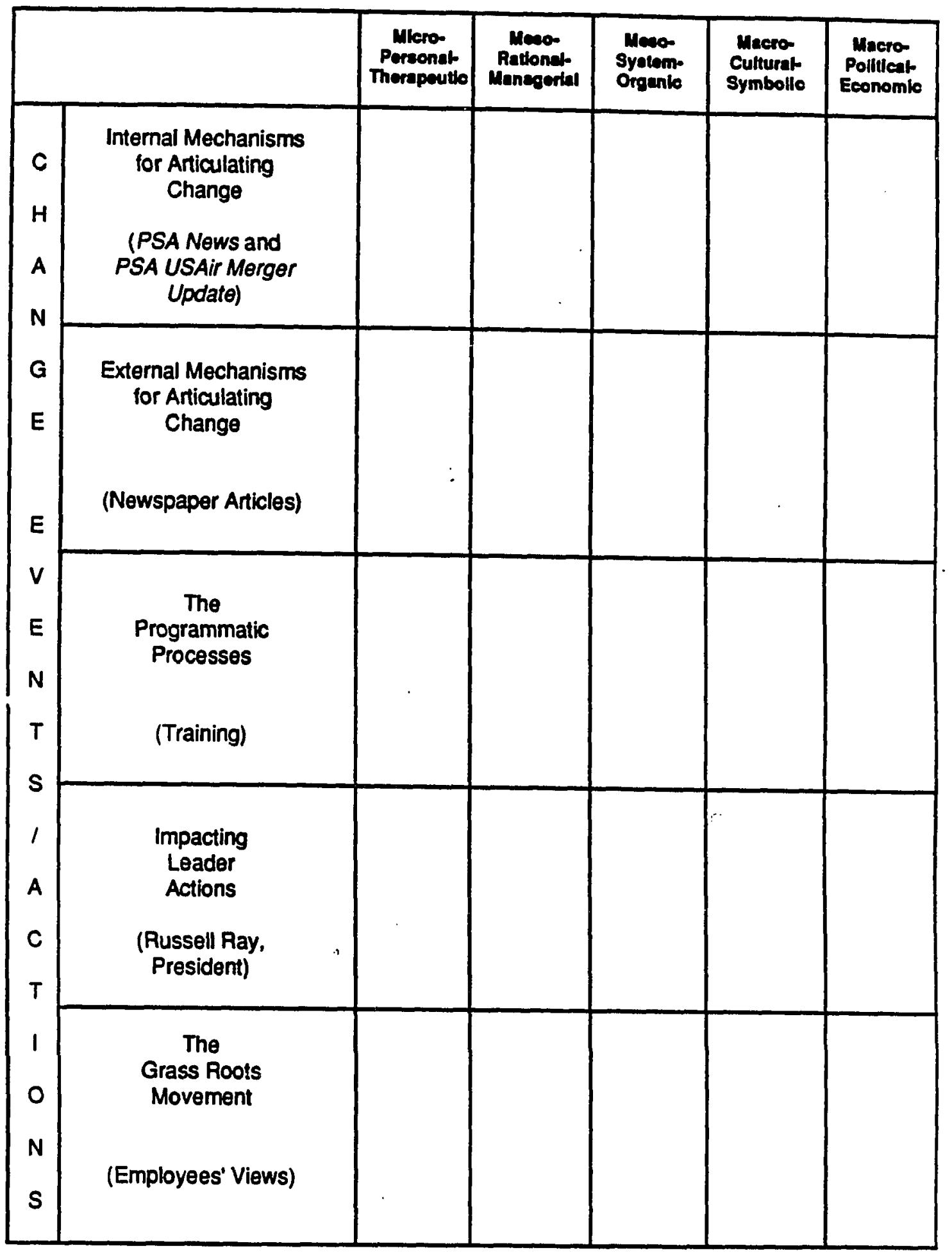

Figure 1. Dimensions of planned organizational change. 
3. The accomplishment of meso-systems-organic actions which view the developmental, communicative, systematic and strategic elements of change.

4. The accomplishment of macro-cultural-symbolic actions which look at symbols, rituals, myths, stories and language.

5. The accomplishment of macro-political-economic actions which look at the power-based, interest-based and coalition-based aspects of change.

In an effort to accomplish the objectives of this case study, the investigator has thoroughly researched five aspects of the change events and the relationship of these events to the previously mentioned predominant change models. The five aspects are:

1. The internal mechanisms and vehicles for articulating the change (e.g., facts, language, symbols, etc.).

2. The external mechanisms and vehicles for communicating change le.g., facts, language, symbols, etc.).

3. The programmatic processes that deepen understanding and knowledge about the change.

4. The key actions of a leader impacting on the change.

5. The grass roots movement that significantly affected the attitudes, beliefs and behaviors about the change. 


\section{Methodology}

The purpose of this study was to determine the degree to which the organizational actions of Pacific Southwest Airlines exemplify the predominant models of organizational change.

The questions that this particular investigation sought to address are embodied within the naturalistic research tradition (Bantz, 1983). They are necessarily qualitative questions that warrant an understanding of the actions, behaviors, processes and communication systems which were the instruments of the change event being studied. The paramount function of the questions to be answered in this study is to provide the most full, rich and comprehensive description of organizational change in action.

Qualitative research has been described as evolutionary or emergent in that the research in progress is guided by an interpretive process (Putnam, 1982). This investigation may be characterized as a qualitative case study because it draws from two approaches that are aimed at interpretive understanding: history and ethnography.

This investigation seeks to paint a thick description of organizational change in action and how that action shaped realities. The study draws from these two approaches in that the researcher attempts to understand how a change event which has already happened (a historical concern) shaped and influenced the social 
construction of organizational realities (an ethnographic concern). Hence, this study is neither purely ethnographic nor unconditionally historical, but rather a blend of two approaches.

\section{The Ethnographic Approach}

Those who operate within the naturalistic research tradition argue that "the social scientist cannot understand human behavior without understanding the framework within which the subjects interpret their thoughts, feelings, and actions" (Wilson, 1983). This is the goal of ethnographic research. In practice, ethnographical studies attempt to depict a culture by uncovering and explicating the means by which individuals "come to understand, account for, take action, and otherwise mangle" the social construction of their realities (Van Maanen, 1983). Wolcott (1983) suggested that "culture is the major concept and point of departure for most American anthropologists, and ethnography is the anthropologist's descriptive account of what he has observed and understood of another culture" (p. 25). While the anthropologist looks at the processual nature of culture, recognizing that it is dynamic and ongoing, the ethnographer seeks to hold it still or take a slice long enough to create a snapshot of it.

It is with this picture of the dynamic process that the ethnographer illustrates the ways in which people organize themselves into interacting social systems. 


\section{Ethnographic Research Procedures}

The ethnographer uses the information that emerges in an investigation to guide and direct subsequent data collection. The essential research instrument for this investigative process is the ethnographer. Therefore, the primary method used in the practice of ethnography is participant observation. In essence, the ethnographer becomes immersed in the realities of those being studied as well as the context in which these realities are being constructed (Sanday, 1983). Consequently, as a participant observer, the ethnographer is able to discover the meaning structures of those under investigation or that culture which is under investigation.

In the ethnographic process of research, participant observation is complemented by a number of equally important information-gathering devices (Pelto, 1970). The method of particular relevance to this investigation is gathering data about the five key mechanisms which were used to shape reality that occurred as events of change in action. Here the ethnographer becomes involved in the change as a true participant observer to gain access to the conceptual world in which the organization, and the people in it, live. By adopting "an informant's mode of thought while retaining full use of this own critical faculties" (Mead, 1959, p. 38), the ethnographer develops an understanding of the methods social actors use in constructing their realities. 
Through the process of participant observation, data and information gathering, the ethnographer enters into an empathic relationship with participants in which she shares in their daily lives and systematically works to understand "the meaning particular social actions have for the actors whose actions they are" (Geertz, 1973, p. 27). Thus, the researcher, through ethnographic inquiry, attempts to develop an understanding about social actors in a specific context and describe what the knowledge gained demonstrates about social life within that very context.

\section{The Historical Case Study Approach}

The case study historian uses information that has already emerged for the purpose of analysis and description. By analyzing an event that has already occurred, the investigator is able to encompass detailed and thick descriptions while insights, trends, and conclusions emerge. The researcher seeks to find specific examples, facts and illustrations of a given phenomenon so that accurate description occurs. This description is often an interpretive analysis which is similar to the writings of a journalist or investigative reporter. The analysis captures the event from some point in time to another point in time. After the event has been captured, having a start and an end, the investigator looks back.

Wilson (1983) suggested that the historical case study approach involves a phenomenon within a framework 
which, because the phenomenon has "encied," deals more with a summative view as opposed to a formative view. The historical case study is a slice of time which, in this particular case, is an six-month period, where a descriptive account of what is observed and understood is documented. Although there are no rules for how long or short the slice of time should be, it should be adequate for properly and deeply describing the event being studied. The description may take the form of a chronology or the flow of given themes.

Change Events

In essence the senior managers of PSA decided to initiate five actions, which were intended to facilitate the change more productively. Each of the five actions or programs were quite comprehensive and extensive in nature, and all were intended to be continuous and ongoing as opposed to one time only actions. These five events will now be reviewed:

The Internal Mechanisms for Articulating Change PSA News Update and PSA/USAir Merger Update were a major focus of this case study. These communication documents were the primary sources of information and became the consistent communication thread throughout the acquisition process. Both communication instruments were intended to be noneditorial, a rather objective and factual account of events, clearly depicting the complex chain of events during a highly uncertain and ambiguous 
time. The vehicles were directed toward all 5,000 members of the PSA organization. These two sources of communication were prepared and released 93 times over a six-month period.

The External Mechanisms for Articulating Change

Newspaper articles from a variety of different locations within the United States, particularly from the Western United States, were another major source of information in this case study. These articles, between October 1986 and June 1987, served as another primary source of information and communication for 5,000 members of PSA, labor unions/officers, investors and customers of the carrier. Literally thousands of articles have been collected and studied to help frame this change event.

The Programmatic Processes

A number of programs oriented around organizational development themes were designed and implemented during the time of acquisition. These programs covered a variety of different change-related objectives. One program in particular is worthy of detailed analysis and that was an intervention in small groups called "Leading in Changing Times." A series of in-depth interviews took place in order to determine what the organization needed to do so that productivity declines during the change process could be minimized. The interview data served as a needs assessment for a group interactive seminar that was delivered to all management employees in the PSA organization. 


\section{The Impacting Leader Actions}

Russell Ray, president and chief operating officer of Pacific Southwest Airlines, was a focus of this case study. Ray was selected because he was a facilitator of change in this case study. His role as transactional or transformational leader is not the focus; rather his roles as orchestrator and constructor of reality are what is most applicable to this study. The research does not argue conclusively whether or not this individual was indeed an effective leader of change. The researcher does, however, analyze the impacting actions of this individual, along with the other aspects of change events, as they relate to the change models mentioned above. The data analyzed are videotaped messages to employees, notes from meetings which were facilitated by $\mathrm{Mr}$. Ray, and a variety of field notes recorded by the researcher in private meetings.

\section{The Grass Roots Movement}

A grass roots movement took place during the change cycle which can be defined as a kind of speaking out uprising. Front line employees felt a strong need to express, vent, communicate, ask questions, and articulate about the acquisition. The most appropriate vehicle for this type of expression was through a nationwide computer communications network. Computer chatter, as it was called, was voluminous. This computer chatter has been captured by retrieving hundreds of messages on printouts 
from employees. Also, field notes are utilized in this descriptive section.

\section{Participants}

There are numerous participants in this qualitative case study. First and foremost, the researcher herself is a substantial participant observer. Since the researcher was planted into the very fiber of the organization during the organizational change, it becomes obvious that her view will become essential and relevant to this study.

Other significant participants include a variety of employees from Pacific Southwest Airlines from different levels and positions within the corporation. These participants include the chief executive officer, executive vice presidents, vice presidents, directors, managers, supervisors, flight attendants, pilots, customer service representatives, ticket agents, reservations agents and mechanics. All of these participants served as key informants in some fashion to the researcher. Site Selection

The actual site from which this case study takes place was at the PSA headquarters in San Diego, California. In addition, however, there are numerous other city locations from which data was collected. These other cities were those on the PSA and/or USAir route systems where employees worked. The satellite cities are referenced in the context of the study as warranted. 
On-Site Observation

The researcher spent over six years with Pacific Southwest Airlines and was present at the corporate offices in San Diego, California, for the duration of the change event being studied. Daily operations in all departments were observed, field notes were constantly collected, and data were consistently and thoroughly collected from: PSA News Updates, PSA/USAir Merger Updates, newspaper articles, videotape scripts, computer printouts, memos, letters, announcements, and more. Specific sites where observations took place include office settings, reception areas, pilot lounges, flight attendant lounges, on-board aircraft, cockpits, hallways, ticket counters, boarding gates, baggage claim areas, ramps and training centers.

\section{Data Gathering}

Bantz (1983) described the documents within an organization as those messages that are generated by members of the organization and have a permanent structure. Bantz explained that since these documents are produced by organizational members, they are indicative of the internal dynamics of the organization. To a naturalistic researcher these documents provide historical data just as the Constitution of the United States provides us with long-lasting information.

Documents in this investigation are a critical element in the study. In addition to the documents 
already mentioned, such as PSA Updates, newspaper articles, etc., the researcher also collected annual reports, training materials, brochures, letters from the chairman of the board and written, audiotaped and videotaped messages from a variety of senior managers within the organization.

Messages that are disseminated publicly in an effort to project a particular corporate image have been labeled by Bantz (1983) as organizational outputs. These outputs can take the form of press releases, television commercials, radio advertisements, billboards, slogans and logos. As with organizational documents, organizational outputs provide the naturalistic research with yet another perspective of the organization. All of these outputs were reviewed by this investigator.

\section{Data Analysis}

All of the documents used were reviewed and analyzed for common themes. A common theme was established when various pieces of information were naturally interrelated. The researcher then attempted to determine if and how these themes were related to the five predominant models of change and the five predominant change actions. Specifically, the researcher looked for concrete examples by drawing inferences from the type of language used, the types of behaviors exhibited, and the types of symbolic elements such as metaphors, myths and specific words which were used to represent broad beliefs and ideas. 
Descriptive Analysis

It is virtually impossible to fully describe the acquisition of PSA by USAir without understanding the history of Pacific Southwest Airlines. This is because so much of the relevance of this single organizational change event emerges out of the significant chronological events of the past. Therefore, Chapter IV is a description of the rich past which shaped PSA.

Chapter $V$ of this case study is a written analysis describing the change event from several different lenses. The lenses or cells are built with the horizontal axis reflecting the five key models of organizational change and with the vertical axis reflecting the five key change actions which were demonstrated during this slice of time. In a form similar to journalistic accounts, Chapter V provides facts, examples, quotes and illustrations which accurately fit in each cell. In turn these examples serve as the basis for a discussion about the primary research questions of this investigation.

Chapter VI will draw some conclusions about organizational change, further exploring the research questions, and blending key findings which can be relevant to both scholars and practitioners of organizational change and leadership. 
CHAPTER IV

THE HISTORY OF PACIFIC SOUTHWEST AIRLINES

Pacific Southwest Airlines (PSA) began initial operations on May 6, 1949, flying a leased DC-3 aircraft with a seating capacity of 31 once a week between san Diego and Oakland via Hollywood/Burbank. The airline charged onto the California scene proclaiming that flying could be safe, punctual, friendly and affordable.

What was it that set PSA apart from other airlines, delivered it from obscurity and ensured its place in the annals of United States airline history? If one asked passengers, employees, even competitors, one simple word comes up again and again: fun. The airline was fun to fly on, fun to be associated with, and fun to work for. "Catch Our smile" became the airline's maxim.

At a time when the rest of America was extremely serious, PSA capitalized on the notion that flying could be fun. While other airlines cloaked their planes and crews in somber shades of blue and beige, PSA planes wore stripes of fuchsia, orange and red with a big, bold smile painted under the nose.

Over the years, PSA eventually expanded its service over most of the Western states, servicing nearly a million passengers per month. Along the way PSA redefined 
the airline industry's corporate culture: innovation was the order of the day. This new culture truly was a shared philosophy, instilled by the airline's founders, Friedkin and Andrews, perpetuated by senior management and implemented by employees.

PSA came to represent the quintessential California mindset: bold, brash, sexy, sometimes off the wall but always friendly, and always fun.

By the end of 1949 , PSA was operating two DC-3 aircraft and had carried 15,011 revenue passengers over 321,112 plane miles. The airline posted operating revenues of $\$ 172,796$ against operating expenses of $\$ 160,902$ for a net profit of $\$ 11,894$.

PSA initially attracted such a large percentage of military personnel that its initials were said to stand for the "Poor Sailors' Airline." The camaraderie in those early days set the tone for PSA's corporate culture. Flight attendants cleaned the aircraft after a flight, pilots loaded the baggage and everyone had bathroom cleaning duty at least once. Everybody basically participated in what needed to get done and they participated in a fun way.

PSA operated over the same three destination route structure in 1950. Revenue passenger totals tripled as the airline carried 45,390 passengers. While operating revenues advanced to $\$ 503,737$, expenses increased to $\$ 517,334$ and a net loss of $\$ 13,597$ was posted. 
By July 1951, PSA added a fourth destination with the initiation of service to San Francisco from San Diego and Hollywood/Burbank at fares of $\$ 17.25$ and $\$ 11.70$, respectively. The airline, however, wasn't just beefing up its routes; it began to actively cultivate an image of fun, innovation and personality.

Scott Newhall, formerly editor of the San Francisco Chronicle and an early PSA frequent flyer, pinpoints one word to describe PSA in its very earliest days: friendly. "Their business was to get you there feeling pretty good. Sometimes it was like a party, with a little band or guitar player. They were on time and had good-looking girls."

At the end of 1951 the number of people employed had increased from the original 50 to 119 with an annual payroll of $\$ 366,605$. The idea of maintaining the California look prevailed. Even in the early days at PSA, it was encouraged that all customer contact employees, particularly stewardesses, as they were known then, display their outgoing personalities and have fun while they worked.

The fleet of DC-3 aircraft increased to four in 1952 as the airline continued to serve San Diego, Hollywood/Burbank, Oakland and San Francisco. PSA carried 92,484 revenue passengers and logged operating revenues of $\$ 1,125,364$ against operating expenses of $\$ 1,151,972$ for a $\$ 26,608$ net loss. 
During 1953, service was inaugurated from San Diego and Hollywood/Burbank to Iong Beach with fares of $\$ 4.80$ and $\$ 2.25$ respectively. For that year, PSA posted a higher loss of $\$ 37,487$ on operating revenues of $\$ 1,454,413$ and operating expenses of $\$ 1,491,900$. The airline carried 115,028 revenue passengers and flew $1,827,903$ plane miles. The number of employees increased to 190 with an annual payroll of $\$ 521,967$.

In 1954, PSA discontinued operations at Oakland and Long Beach, and reverted to a three-city route structure, serving only San Diego, San Francisco and Hollywood/Burbank. Fares ranged from $\$ 5.45$ to $\$ 19.05$. The number of revenue passengers decreased by approximately 13,000 from the previous year as PSA carried a total of 102,124; however, the airline posted a net profit of $\$ 26,711$.

PSA purchased two McDonnell-Douglas DC-4 aircraft in 1955 to replace its DC-3 equipment. The larger and faster DC-4s were configured to carry 70 passengers, more than twice that of the older DC-3s. As profits rose, fares went down. The $\$ 19.05$ San Diego-Oakland fare dropped to $\$ 15.44$, the Burbank-San Francisco fare was lowered from $\$ 13.50$ to $\$ 9.99$, while the San Diego-Burbank fare remained unchanged at $\$ 5.45$. These fares remained constant through 1958.

The airline added a third DC-4 aircraft to its fleet in 1956 and carried 191,221 revenue passengers over the 
three-city route structure. Operating revenues increased to $\$ 2,122,376$ and operating expenses increased to $\$ 2,063,788$. Continuing a three-year trend of profits, PSA earned $\$ 58,588$ for the year.

In 1957, a fourth DC-4 was added to PSA's fleet of aircraft and the airline's employees increased to 246 with an annual payroll of $\$ 762,294$. By now, PSA had begun a reputation of having a playful personality. Employees continued to demonstrate a positive attitude with customers. Revenue passenger totals increased to 256,454 as PSA posted another profit of $\$ 196,606$.

August of 1958 marked the inauguration of service to Los Angeles International Airport and, once again, the number of destinations in PSA's system increased to four. The San Diego-Los Angeles fare was the same as the $\$ 5.45$ San Diego-Burbank fare. Fares for Los Angeles-San Francisco were set at $\$ 11.81$, and the San Diego-San Francisco fare rose to $\$ 17.26$. That year, PSA carried 295,818 revenue passengers and flew 1,935,465 plane miles as it posted a year end profit of $\$ 322,031$.

The introduction of three Lockheed L-188 Electra propjets into PSA's fleet highlighted 1959. The 98-seat aircraft was ideally suited to the airline's four destination route structure and revenue passengers increased to 355,099 while plane miles exceeded the 2 million mark for the first time. PSA posted revenues of $\$ 4,362,921$ against expenses of $\$ 3,907,015$ for a net profit 
of $\$ 455,906$. In 1959 , PSA employed 300 people and the annual payroll exceeded $\$ 1$ million.

The stewardess population was now required to wear false eyelashes and bright colored make-up. Image and appearance were very important.

Disposing of its DC-4 equipment, PSA entered the 1960 s with a fleet that consisted of three Electras and one 92-seat DC-6. Available seat miles, plane miles and revenue passengers increased to $289,100,100,2,950,000$ and 621,280 respectively. In october of 1960 , PSA reinstated service to Oakland but discontinued again in March of 1961. Fares remained at 1958 levels as the airline posted a year end profit of $\$ 499$.

PSA management actively encouraged crew-passenger interaction; by the sixties, flight attendants were collecting passenger tickets on the planes in order to facilitate more contact. Carol Austin, a twenty-three-year veteran, recalls those days: "We treated customers as if they were guests in our homes. We were never allowed to go into our work area and hide out, talking among ourselves." Flight crews were even given opening gambits to initiate conversation with passengers. PSA had a perpetual open door policy in the cockpit, until the Federal Aviation Administration ordered cockpit doors closed in 1972 .

PSA was now dubbed the "Personality Sells Airlines." But how does a faceless corporation, whose work centers on 
inanimate machinery, evolve a personality?

Len Gross, principal of Gross, Pera \& Rockey, the firm that became PSA's first ad agency, credits a management team that was relaxed and supportive. "They were a young, growing airline and they had a lot of fun. Their competitors were big guys who were very stuffy, formal, terribly dignified. PSA was a bunch of gung-ho kids who wanted to build something."

It helped that the operation was small: 50 employees in 1949, doubled to 119 by 1951 , and still only 1,899 in 1968. Former chief pilot Bogle says he knew the home telephone number of each and every crew member and often talked to each of his pilots nightly. "We thought we were big, but until 1968 we weren't really," he says now. "We were big in heart, though."

All agree that one of Kenny Friedkin's greatest legacies was his belief that flying should be fun. Andrews who carried on as president after Friedkin's death in 1962, articulated that philosophy: "Life is tough enough. If we're not having fun, let's go do something else."

Longtime flight attendant Austin echoed this sentiment: "Our duty days were twelve hours and thirty minutes. That's six hundred hellos and goodbyes. We sought to make almost a sporting event of it by involving the passengers as well as crew members in the fun. The uniqueness of this airline? We got people to loosen up." 
Added to this was Friedkin's regard for his employees which he viewed as his extended family. Everyone, from clerks to senior managers, was on first name, sometimes even nickname, terms. Bonnie Johnson, who joined the airline's accounting department right out of high school of 1960, recalled that the big boss never even wore a suit. "Kenny was one of us, and we were all working toward the success of PSA."

With the disposition of the DC-6 and the addition of another Electra, PSA's 1961 fleet stood at four Electra propjets. The carrier flew 713,064 revenue passengers over 3.3 million aircraft miles. Operating revenues increased to $\$ 9.7$ million and a year end profit of $\$ 310,483$ was posted. A fifth Electra was added to the fleet as PSA's revenue passenger totals exceeded the 1 million mark for the first time in 1962. PSA carried $1,032,514$ passengers over its four city system and enjoyed its best year to date, showing a profit of $\$ 1,368,770$.

With TWA, United and Western all flying the same four hundred mile corridor between San Francisco and Los Angeles, how had PSA, the comparatively small intrastate airline, garnered a 50 percent market share? They all had the same type of aircraft and the same schedule, and by this point, the same fare structure. What accounted for PSA's unprecedented success? In a word: stewardesses. Every airline in the country had female flight attendants, but PSA was known nationally for its sun 
kissed beauties. Not only were they pretty, agreed the flying public, they were also warm, intelligent, friendly and funny.

As flight attendant uniforms began to get briefer and more form fitting, PSA discovered that sex sells. If nothing else, PSA will be remembered for its flight attendants and their uniforms. In a San Francisco Chronicle editorial, Scott Newhall dubbed them "the cupcakes of the airplanes, the vestal virgins of the air."

Initially, PSA flight attendants wore the traditional two piece military style business suit used by most other airlines. However, around 1962, PSA departed from tradition and introduced the "banana skin," so called not because of its color, which was brown, but because of its form fitting silhouette. The banana skin was, as one flight attendant recalls, "definitely revealing."

Carol Austin, who wore one, describes the "skin": "It was very form fitting with a zipper all the way up the front. You really had to peel it on and off. Everything showed. It was definitely ahead of its time because everyone else was in a boxy business type uniform."

In 1963, the airline operated a fleet of six Electra aircraft, a figure that would remain constant through the following year. The airline flew 5.5 million plane miles and carried $1,305,058$ revenue passengers, up 272,544 over the previous year. PSA posted operating revenues of $\$ 17,432,534$ against operating expenses of $\$ 15,180,815$ for 
a net profit of $\$ 2,251,719$. On February 3, 1963, Pacific Southwest Airlines became a public corporation.

PSA earned a net profit of $\$ 2,945,881$ based on revenues of $\$ 20,455,295$ and expenses of $\$ 17,509,414$ for 1964. The airline carried 1,532,243 revenue passengers and flew 6.5 million plane miles over the four city route system.

In 1965, PSA entered the jet age as it added five Boeing 727-100s to its fleet of six Electras. The Boeing aircraft were configured to seat 128 passengers. With the introduction of jet equipment into its fleet, PSA's available seat miles increased to nearly 1 billion as the airline carried 1,863,088 passengers and earned yet another profit of $\$ 2,034,932$. In January, PSA initiated service to Oakland in June the airline was listed on the New York Stock Exchange.

PSA added two more Boeing 727-100 aircraft to the fleet during 1966, bringing the fleet total to six Electras and seven Boeing 727s. With this equipment, PSA nearly doubled its passenger totals as it carried $2,712,811$ travelers and posted a net profit of $\$ 4,307,289$. In May, PSA inaugurated routes between San Diego/Los Angeles/Burbank and San Jose and offered fares of $\$ 19.85$, $\$ 13.50$ and $\$ 13.50$ respectively.

During 1967, the airline added three more jet aircraft to the fleet, a Boeing 727-100 and two McDonnell/Douglas DC-9s. The Douglas aircraft were 
configured to carry 110 passengers. By the end of the year, the six Electras were phased out of the fleet and PSA became an all-jet airliner. Year end profit was $\$ 4,159,823$ and service was inaugurated to Sacramento from San Diego with a fare of $\$ 21.59$ and from Los Angeles with a fare of $\$ 15.24$.

During 1968, PSA augmented its fleet of seven 727-100s and two DC-9s with seven 727-200 aircraft and four 737-200 aircraft. By year's end, the fleet total of jet aircraft stood at 20. The new stretch 727 s were configured for 159 passengers, and the twin-engine 737s held 114 passengers. PSA carried $3,997,524$ revenue passengers over a system that included seven California destinations with ontario becoming the eighth when service was inaugurated there in June, 1968. That year, PSA employed 1,899 with annual payroll of $\$ 13.6$ million. The airline earned $\$ 4$ million on operating revenues of $\$ 56.2$ million and operating expenses of $\$ 52.2$ million.

PSA's 1969 fleet consisted of one DC-9, one Boeing 727-100, fourteen Boeing 727-200s and nine Boeing 737-200s. PSA carried 4.4 million passengers and posted a year end profit of $\$ 3,747,016$.

PSA entered the seventies with an all Boeing-equipped fleet that included one 727-100, sixteen 727-200s and nine 737-200s. The company topped the 5 million mark in passengers carried and posted a profit of $\$ 3.6$ million. Service was started to Long Beach in December of 1970 . 
For the year, the airline flew 20.6 million plane miles and 2.9 billion available seat miles.

In 1970 another critical cultural move happened, the smiles were painted on the planes and it then became the central identifying artwork in all advertising, whether it was a smiling plane or just a smile.

The print ads and all collateral materials, from brochures to ticket folders, featured some play on this smile. A 1976 ad proclaimed, "California is all smiles." When PSA began flying interstate, "Catch our smile to Portland" and "Smile to Phoenix" made an appearance in 1978 and 1979. When the airline became the official airline of Disneyland, PSA offered "magical smiles." When the British Aerospace 146-200 jets joined the fleet in 1984, they were christened "Smiliners." Still later, when the USAir merger was announced in 1986, the smile theme was front and center with the advertising tag line, "Now our smile is even wider."

The smile came to be so closely identified with the airline that it became almost a symbol of the magical aura and lightheartedness of PSA. Russell L. Ray, Jr., named president and chief operating officer in 1985, says that when the USAir merger was announced, "PSA people had two questions: 'What's going to happen to me?' and 'What's going to happen to the smile?' Not necessarily in that order. It's the darnedest thing--I can't explain why the smile is so important, but it is." 
In 1971, PSA's fleet totalled 27 jet aircraft and realized a year end profit of $\$ 4,239,335$. A milestone was hit when 5.6 million passengers were carried that year, an increase of nearly a half a million over the previous year.

Service to Fresno and Stockton began in July of 1972. Inaugural fares between Los Angeles and Fresno and Los Angeles and Stockton were $\$ 14.82$ and $\$ 18.52$ respectively. That year there were 2,594 PSA employees with a $\$ 27$ million payroll budget. That year, PSA topped the 6 million maxk in revenue passengers and recorded a profit of $\$ 5,957,485$.

PSA flew 23,063,794 plane miles and carried $6,356,875$ revenue passengers with a fleet of nineteen 727-200 and eight 737-200 aircraft during 1973 .

Things began to sour in November 1973 when the airline was struck for the first time in its history by the Teamsters Union. Approximately six hundred maintenance personnel and seven hundred station managers kept to the outside of the picket line. Management and supervisors pitched in and the airline continued operations, losing only about $40 \%$ of the normal schedule. Emotions ran hot, though, and the strike wounded the PSA psyche.

The carrier also made its fair share of strategic mistakes. In 1972, with the Civil Aeronautics Board holding firm in its refusal to grant PSA permission to fly 
interstate routes, Andrews, never at a loss for a good marketing idea, steered his company into an ambitious plan for diversification: the Fly/Drive/Sleep campaign. Because passengers were confined to California, the thinking was, he says, "to give passengers a reason to fly with us, to give them something more, something better than the competition." PSA would provide a total service to passengers: a plane to fly them to their destination, a car to drive once they got there and a bed to sleep in at night. Each component of the campaign would promote the others.

Most notably, PSA bought the hotel portion of the Queen Mary in Long Beach, along with several other operations up and down the state, including the Islandia Hotel in San Diego. Additionally, the airline bought a car rental business and several radio stations. The Fly/Drive/Sleep plan was probably ahead of its time, and the campaign quickly fizzled. Fergie Fulmer, a PSA employee at the time, says it was doomed by commuter behavior: "People go up and back the same day, so it didn't tie in as it should have." For his part, Andrews admits there were two problems: "We should have let the experts run the program instead of trying to do it ourselves, and our timing was bad. Timing killed it." Just as the programs got under way, fuel costs zoomed into the stratosphere: prices increased tenfold and the crunch was on. 
Suddenly PSA, the darling of the industry, the airline that could do no wrong, was encountering turbulence. As consumer affairs director Judy James says, that revelation came as something of a shock: "People were disappointed because for the first time an attempt at doing something unique, which PSA was always good at, failed."

The labor dispute was settled on December 23; however, it was not until several months later that PSA resumed normal operations. During 1973, PSA's operations revenues topped the $\$ 100$ million mark for the first time as a net profit of $\$ 627,123$ was posted.

In 1974, PSA took delivery of two Lockheed L-1011 Tristars. The wide bodied equipment were configured for 296 passengers and were initially introduced on the heavily travelled Los Angeles/San Francisco route. Not only were the L-1011s fuel guzzlers, but their huge capacity proved a hindrance. Frequent flyer scott Newhall, shuttling back and forth as part of his duties as editor of the San Francisco Chronicle, observed that it took as much time to load and unload the passengers as it did to actually fly from San Francisco to Los Angeles. "The L-1011 was a fine plane to fly between California and Czechoslovakia, but for this commuter run it was too big." Due to a recessionary economy and the government enforced fuel quotas, the new generation aircraft were grounded in 1975. For the year PSA recorded a profit of $\$ 1,589,627$. 
PSA added a twelfth destination to its route structure in April of 1975, when services commenced to South Lake Tahoe. The fare from Los Angeles to Lake Tahoe was $\$ 30.00$. During 1975 , revenues of $\$ 152,521,000$ were realized while carrying $6,436,436$ passengers. However, PSA, Inc. incurred a loss of $\$ 16.7$ million resulting from the establishment of a provision for loss on the I-1011 Tristar aircraft program and a provision for anticipated losses on the disposition on the company's subsidiary hotel and broadcasting operations.

William R. Shimp became chief executive officer upon the retirement of J. Floyd Andrews during 1976. PSA sold the remaining two Boeing 737 aircraft and added two leased Boeing 727-100s, bringing the fleet to twenty-three 727-200, three 727-100, two Lockheed Electra and two L-1011 aircraft. The two L-1011s remained grounded as the company sought a prospective buyer for the aircraft. During the year, PSA continued the plan to dispose of subsidiary hotel and broadcasting operations, selling the remaining radio stations and two of the four hotels. PSA had earnings of $\$ 3,501,000$ on revenues of $\$ 166,874,000$ and carried $6,591,000$ revenue passengers. Fares remained steady during 1976 .

During 1977, PSA applied to the Civil Aeronautics Board for service from California cities to Las Vegas and Reno, at fares from 18 to $43 \%$ less than the fares charged at that time. If approved, the Nevada service would 
become the first interstate routes for the airline. In December, PSA received permanent authority from the California Public Utilities Commission to serve South Lake Tahoe from Soutinern California and San Francisco. The airline took delivery of five used Boeing 727-100 aircraft, two of which replaced leased 727-100s. Profits were recorded at $\$ 2,567,000$.

After a great deal of effort PSA was finally granted approval by the Civil Aeronautics Board in 1978 to serve Nevada. One way fares on the Las Vegas-San Diego market were lowered by PSA to $\$ 30$, a reduction of $35 \%$ from existing fares on the market. The new interstate service was the highlight of the year until, on september 25, 1978, tragedy struck. PSA flight 182 collided in midair with a privately owned Cessna 172, killing 144 people, including 37 PSA employees.

Judy James, a PSA employee at the time, recalls that day with stunning clarity: "Flight 182 was the unthinkable. I always felt safe on our airline; it couldn't happen to us. It was particularly difficult because of the number of PSA employees, our friends, who were on board."

During that same year, PSA became the first domestic airline to order the new Douglas DC-9 Super 80 aircraft, the most quiet and fuel efficient commercial aircraft produced. A total of 12 airplanes were ordered for delivery in 1980 and 1981. Throughout the year, PSA 
continued its aggressive expansion plans with applications to the Civil Aeronautics Board for service between California cities and Phoenix, Seattle, Salt Lake City, Portland, Houston and seven cities in Mexico. That year, PSA carried 7.8 million passengers and earned $\$ 11.5$ million on revenues of $\$ 229.8$ million.

In 1979, PSA's first full year as an interstate carriex, success soared, with the airline carrying a record 8.6 million passengers and enjoying its best year ever financially. PSA added Phoenix, Arizona and salt Lake City, Utah to the route system during the year, while dropping service to South Lake Tahoe and Monterey, California. At the end of 1979, PSA's route system included 15 cities in four states. Although the interstate routes were profitable within 90 days, PSA's aggressive expansion plans were tempered somewhat by skyrocketing costs and limited quantities of aviation fuel. Fuel also affected PSA fares. By the end of 1979, the carrier still was offering rates below the national rate making formula, but the one-way fares rose dramatically during the last half of the year, reflecting a doubling of fuel costs during that time period. Sample year end fares were: Los Angeles-San Diego, \$26; Los Angeles-San Francisco, $\$ 40 ;$ and Los Angeles-Las Vegas, $\$ 38$.

The airline completed one major building and broke ground on another during 1979. A $\$ 2.5$ million 
reservations center was opened in the Scripps Ranch Business Park in San Diego, while construction began on a multi million dollar training facility adjacent to the reservations complex. All the while, PSA enjoyed its best operating year with revenues of $\$ 335,838,000$ and earnings of $\$ 23,097,000$.

1980 was one of its most dynamic years as the airline became an international carrier with service to Mexico, became inoperable for the first time in its 32 year history by a strike and became the first United States airline to operate the McDonnell-Douglas super 80 aircraft.

In April, service began to Puerto Vallarta and Mazatlan, Mexico from Los Angeles, which meant that the airline had made a full transformation from intrastate to interstate to international carrier in less than 18 months.

The pilots, represented by the Southwest Flight Crew Association, struck the airline for 52 days, starting on September 25, forcing PSA to halt scheduled service for the first time in its history.

The pilots' strike affected passenger volume and earnings for the year. Some 6 million passengers flew the carrier during 1980 with PSA, Inc. reporting year end earnings of $\$ 12.6$ million on revenues of $\$ 370,204,000$. While the 153-seat super 80 is quiet, the $30 \%$ improved fuel efficiency over the Boeing $727 \mathrm{~s}$ helped to 
keep fare levels low in the face of rising fuel costs. At the end of 1980 , PSA was operating a fleet of twenty-two Boeing $727 \mathrm{~s}$ and one super 80 .

PSA's aggressive fleet transition program highlighted 1981 as the airline received twelve DC-9 Super 80 aircraft from McDonnell-Douglas. The new plane's efficiencies, particularly in the area of fuel consumption, saved PSA approximately $\$ 1.7$ million per year over the aircraft it replaced. By year end, the operating fleet consisted of thirteen super 80s, fifteen Boeing 727-200s, and three Boeing 727-100 aircraft.

With a major training program accompanying the delivery of the new aircraft, the new multi million dollar training center at the Scripps Ranch Business Park opened. The center housed the nation's first DC-9 Super 80 simulator.

A deepening recession and flight limitations imposed by the Federal Aviation Administration after the national strike by the Professional Air Traffic Controller Organization had an adverse effect. Although the airline operation lost $\$ 17$ miliion during the year, profitable subsidiaries plus the sale of aircraft and proceeds from safe harbor leasing, gave $\mathrm{PSA}$, Inc. a record $\$ 28.5$ million in net income for the year.

PSA entered three new cities during 1981, adding Orange County, California in october and Seattle, Washington and Tucson, Arizona in December. In keeping 
with PSA's low fare tradition, fares on the new markets were lowered below competitor's rates.

In 1982 the fleet transition continued with eight more super $80 \mathrm{~s}$ added during the year. By October twenty-one super $80 \mathrm{~s}$ were online with nine Boeing $727 \mathrm{~s}$, thus making PSA the first major airline to operate the majority of its fleet with new-generational aircraft.

Passenger boardings were up 16.68 and PSA flew 7.1 million passengers. Available seat miles were the highest ever achieved and revenue passenger miles were the second highest in PSA history.

The economic recession did not abate and, as a result, earnings were adversely affected. Despite an airline operating loss, PSA, Inc. had year end earnings of $\$ 19.5$ million.

PSA improved its competitive position during 1982 by increasing service between California and Phoenix and at Burbank. In June, PSA reinstated the Midnight Flyer, its late night, low fare service, as it had been suspended in 1978. In September, service to Puerto Vallarta and Salt Lake City was discontinued.

The year ended with PSA entering into an agreement with Braniff Airways that would allow the carrier to lease and purchase assets from the bankrupt airline to form a new PSA division that would operate with a hub at Dallas-Fort Worth Regional Airport. Thirty repainted Braniff Boeing $727 \mathrm{~s}$ were planned to be leased by PSA to serve 16 new cities. 
In 1983, PSA abandoned its negotiations with Braniff early in the year when deadlines that the airlines set for agreement to be reached could not be met. PSA instead focused its attention on markets in the west and later in the year inaugurated service to Portland, Oregon; Spokane, Washington; as well as Albuquerque, New Mexico. This was the largest expansion in PSA's recent history.

PSA became the official airline of Disneyland under a 12 year agreement that included several exclusive marketing ties and a PSA sponsored attraction at the famed theme park. Other major marketing developments were the introduction of the Executive Flyer Program for frequent travelers, and, for the first time, seat assignment on all flights was initiated.

Competitive pressures abounded during 1983 from established carriers and new entrants in PSA markets. Although PSA set records for revenue passenger miles and available seat miles, PSA, Inc. reported a net loss of $\$ 9.3$ million.

Late in the year, PSA contracted with British Aerospace to acquire twenty new BAe 146-200 jets, a 100 seat aircraft intended to give the company more flexibilities to increase frequencies in existing markets and to consider expansion into new markets. The BAe 146 aircraft demonstrated to be the quietest commercial jetlines on takeoff ever developed, also was extremely fuel-efficient, burning about one-half the amount of fuel as a Boeing 727-200. 
Eight of the new generation planes were to be delivered by the end of 1984, at which time the $727 \mathrm{~s}$ in the fleet would be phased out. The remaining twelve $146 \mathrm{~s}$ were set for delivery in 1985, and the contract with British Aerospace included an option for an additional 25 aircraft.

At the end of 1983, the fleet included twenty-five Super 80s, eight Boeing $727 \mathrm{~s}$ and four DC-9-30s.

The year of 1984 was dominated by measures to cut the costs of the airline operations through continued fleet transition to more efficient aircraft and through the negotiation of new, lower cost labor contracts with all employee groups. Both were successful; by the end of the year, the company was operating the most modern, fuel efficient and quiet fleet of any carrier in the country, and necessary wage concessions from employee groups had been approved.

The new labor contracts, in effect through 1987, offered all employees a 15\% stock ownership in the airline and a profit sharing program equal to $15 \%$ of the airline's annual pre-tax profits. In exchange, the employee groups agreed to a $15 \%$ reduction in compensation and an equal increase in productivity. The new contracts saved the organization an estimated $\$ 20$ million a year in labor costs.

PSA took delivery in 1984 of its first six BAe 146-200 jets, named "Smiliners," with the first revenue 
flight occurring on June 20 in Oakland. A 26th Super 80 was also delivered which would substantially increase frequencies throughout the route system.

Eight Boeing 727 s were sold or leased in 1984, with the last aircraft making its final flight in November. The workhorse of PSA for nearly 20 years, the $727 \mathrm{~s}$ had logged in excess of 300 million miles and carried more than 92 million passengers.

Several new customer conveniences were introduced in 1984. In January, operations at Los Angeles International Airport moved to the new PSA Terminal One, the first reached upon entering the busiest airport in the system. Automatic check-in machines were installed at many airports, reducing passenger congestion at the ticket counter, and the Executive Flyer Program was expanded to include affiliation with a worldwide carrier, TWA. In September, PSA reinstated nonstop service between stockton and Los Angeles, offering the only all jet service between those cities.

Sadly, William shimp, chief executive officer since 1976, died of a heart attack in May. In addition to having served as chief pilot of the airline for a number of years, Shimp had guided PSA through some of its worst turbulence, facing economic realities with equanimity. Paul Barkley, formerly PSA's president, succeeded him. The decade's midpoint was marked by an increased concentration on customer service as the $146 \mathrm{~s}$ were 
reconfigured from 100 seats to a more spacious 85 seats. More of the British jets were delivered, allowing PSA to make the largest single day expansion of new routes in its history: seven more cities now welcomed the grinning birds.

The lineup of the airline's top management also changed as Russell Ray was named president and chief operating officer of PSA. Paul Barkley was named chairman of the board in addition to chief executive officer.

With the addition of new destinations and an expanded fleet, PSA registered a marked increase in passenger volume in 1985 .

PSA ended 1985 with the largest single day expansion in the airline's history, inaugurating service December 19 at Eureka, California; Medford and Eugene, Oregon; Tri-Cities and Yakima, Washington; Boise, Idaho; and Cabo San Lucas, Baja California, Mexico. In October, PSA also became the first commercial jet carrier to begin service at Bellingham, Washington.

The expansion was possible with the addition in 1985 of fourteen BAe 146s, completing the original order of twenty. Fleet additions, including two super 80s, allowed PSA to substantially boost frequencies in existing markets. Most notably, the airline introduced the PSA Expressway, offering departures every half-hour between Los Angeles and San Francisco airports, and more than tripled the number of daily departures at Orange County 
Airport, where the exceptionally quiet BAe 146 had qualified for additional flights. To accommodate the growth, service to Albuquerque was discontinued.

A number of customer conveniences debuted in the year. All of the BAe $146 \mathrm{~s}$ were reconfigured from 100 seats per aircraft to 85 , making PSA the only airline in the west with a three/two seating arrangement for its entire fleet. The long awaited, premier position Terminal A at San Francisco also opened as was a new curbside terminal at oakland. A second reservations center, located in Reno, was opened to help reduce costs and call-waiting.

A record number of passengers were boarded in 1985, more than 9 million, but fare wars provoked by new entrant, low cost competitors in several markets led to a $\$ 648,000$ loss. PSA, Inc., meanwhile, benefited from non airline activities and recorded a $\$ 26.8$ million profit.

If PSA could be considered a person, and many employees did anthropomorphize it, 1986 was the year it was given in marriage. In December, PSA's parent company announced that Washington, D.C. based USAir Group, Inc., had come up with the bride price.

By 1986, as merger mania swept the airline industry, PSA's struggle to remain independent had grown more painful. As recently as 1984, Chief Executive officer Barkley had sworn PSA could go it alone, "and I meant it." The environment, however, changed with each merger. 
PSA's success had driven Republic Airlines out of the major Western markets, until Republic Airlines was acquired by Northwest Orient. Suddenly Republic/Northwest Orient had huge resources and moved to recapture the West. A similar scenario took place when Delta Airlines acquired Western Airlines, which had been edged out of the commuter territory PSA so prized. Delta was a short-haul specialist, just like PSA, and very strong; its clout encouraged Western to again challenge PSA. In a similar move, Frontier Airlines was bought by Continental Airlines, making Denver unfriendly to the grinning jets. The final trauma was the purchase of Air Cal by American Airlines in November 1986. With the power of its computer reservations system, American/Air Cal was now able to fight PSA on its prized turf: the north-south commuter route along the coast.

By now, said Paul Barkley, "it was inevitable we would have survival problems and we would be bought." other carriers, faced with a choice of either buying a billion dollars' worth of aircraft and heading for the already saturated west Coast, or, alternatively, buying the one remaining independent carrier, which already had a billion dollars' worth of equipment and a major piece of the market, naturally chose the latter.

Within one hour of the American/Air Cal merger announcement, recalls Barkley, the phone rang. It was the boss of USAir Group, Inc., wanting to know if the company 
that owns USAir could come courting PSA.

For most PSA loyalists, it was more of an arranged match than a love affair. The overriding emotion was one of sadness: sad that the fun was over, sad that the dreams, that inexplicable PSA mindset, would be over.

Rudy Pfeiffer, who retired that year after 22 years with the airline as an aircraft electrician, voiced the duality of emotion many long serving PSA personnel felt: "I kind of hope the merger goes through for them, but I was also hoping PSA's colors would be around for a long time.

I knew all the early guys, and that's partly why I retired: I didn't want to see it happen."

Bonnie Johnson, the twenty-seven-year accounting department veteran, was philosophical: "When the planes are painted and the smile is no more, it will be a sad day for California and a sad day for me. But things go on. USAir is a good company."

Frequent flyer scott Newhall, who never tired of lovingly razzing PSA, said he'll "go to pieces" after the merger. But he had some good advice for USAir: "If they'll serve dry roasted peanuts and put their stewardesses in chocolate-colored banana skit outfits, I guess I'll fly with them."

Flight attendant Carol Austin is characteristically upbeat: "PSA won't die out. PSA will remain because the people at PSA are PSA. Even though we may be wearing dark 
blue, we'11 still be wearing hula orange lipstick."

For founder and former Chief Executive officer

Andrews, the merger/marriage of the airline he nurtured so lovingly was especially painful, "like pulling my arm out and beating me with the bloody stump." PSA, as he knew it, would be no more. If PSA were truly a person, then, what would Andrews say in her memory?

"She was a good lady: proud, exciting and full of life. A little hard to manage at times, but always dependable. And at all times a people lover." 


\section{CHAPTER V}

THE ACQUISITION OF PSA BY USAIR: CHANGE IN ACTION

As the preceding chapter illustrates, the history of Pacific Southwest Airlines is rich and extensive. For decades, PSA was an innovator in beating the competition by offering its customers low fares, on time performance and a spirit of service which put the carrier on the map as an airline with tremendous personality. For a carrier that dominated the west, it is quite interesting that even the eastern part of the United States was well aware of this airline with the unique style. The growth and the consistent operating profits generated a feeling of dominance and energy which was reflected in the manner in which employees and customers alike viewed the company.

Long before December 8,1986 , however, there was considerable ambiguity among employees and it penetrated the entire organization. Every day there was news from the press about the airline merger mania. There were rumors everywhere regarding the potential of a purchase of Pacific Southwest Airlines from some other airline. Operating profits had ceased for several years and the corporate tax laws of 1986 made it somewhat obvious that PSA was vulnerable to being acquired. 
The full and rich history that PSA enjoyed made the speculation of a merger frightening. Employees were generally attached to the identity of the airline. Many employees had extensive time commitments to the organization as exemplified by the average seniority, companywide, being eight and one-half years. Attrition had always been low, well under single digit percentages, and supply for employees was high while demand was low. Employment selection in the flight attendant population, for example, was one selection for every six hundred applicants. Many other job classifications were similar. Communication of the Change

On December 8, 1986 PSA's chairman wrote his letter to all employees (see Figure 2) announcing the approval agreement between the boards of directors of Pacific Southwest Airlines and the PSA Group, and the USAir Group, the holding company for USAir, to acquire PSA for $\$ 17.00$ a common share. Employees were shocked.

The chairman, Paul Barkley, explained that during the recent airline consolidation movement, PSA had maintained its desire to remain an independent carrier, but that the boards of directors had a legal responsibility to represent the best interest of the shareholders. The USAir offer had been a substantial one which protected the best interests of shareholders and employees alike. The offer, which was $\$ 5.75$ more than the closing price of 


\section{PSA Perspectives from the Chairmath \\ Decenter 8, 1986}

Dear Enployees,

As you tro now aware, the bourds of directors of pacifle Southwest Alrlines and of PS Group, Inc. have approved an agreement whereby USALr Group, the nolaing compeny for USAIs,

PSA, during the recent alsilne consolldation movement, has malntilned lts desire to resein an indopondent carrior. The boards of disectors, noweves, have legal tosponsibliity to represent the best Interest of their shuranolders. The
USA1r Group offer is substantial and an offer the boards bellove 18 In the Dest interests of shareholders and employees alike. Therefore, the offer alli be put to the snarenolders por approval.

As omployess it is good to know that USALE has a raputation for trating 1 ts workforce Palrly. Ed Colodny, chafrwan and oresident of USALE Group, has assured me there will be no reduction In vage rates and that PSA W111 becone reasen in growing USAL. In the Inter1e, PSA anagenane subsidiary of USALs Group.

The offer, whleh $18 \$ 5.75$ more than the closing prlce of alrline stock on Frlday. W11l Increase the value of the PSA employee trust to soout sas atilion. You 111 racill the orloinsl valuetion of the trust conducted. In lete $198 \mathrm{w}$. sil.4 militon. In sddition. anoloyess have an option to purchase $1,663,200$ shaxes at $\$ 8,33$ per share; at $\$ 17$ per share, enis option has a value of $\$ 14.3$ mdilion. Thus, the total amount for ald particlpating enployees 1s spproximately 360 illilon, goln of nearly 450 percent.

There are a nuaber of hurales to be cleared before the areenent is consunated. In addition to shareholder approval, varlous Pederal agencles must approve the transaction ond PSA must amend cortain scope clause agreanents with its bargaining units. Mo -ill bo discussing thene lasues olth the undons, and I fool confldent that thay 111 sed the agreement has the anployese' bese intereste in wind.

In accordance wth the exlsting labor agreentents, PSA employese have the right of plrst refusal to acquire the alrline st the same prlee offered by USASr Group. Information on tnis right is being sent to every PSA employee.

I an provd of al1 PSA employees; you have nelped to establish PSA as the West's leading alrifne. And wnile 1 an certain that you would have oroferred to see PSA remain an Independent alrilne, the realities of this competitive and complex businass are suen that it would have been a tremendous uphill battie por PSA - one that could have been ilnanelally denabilitating -. agalnst the glants of the industry.

Instead, wo now have an opportunity to be a gart of a very PInanclally sound and guecessful alrline. USAit has one of the strongest balance sheets in the Industry. It Is also an arilne that wante to grow wlth PSA. Our strong Wost coust route systes complemants USAIr's oxtensive East Coast network and gives the comblned entity nuaerous opportunletes.

sincerely,

PAuL C. BarkLEY

Chief Executive ofpicer

Figure 2. Letter from PSA's chairman, Paul Barkley, announcing the merger. 
airline stock the Friday before, increased the value of the PSA employee trust to about $\$ 45$ million. The original value of the trust in late 1984 was $\$ 11.4$ million. In addition employees had an option to purchase $1,643,100$ shares at $\$ 8.33$ per share; at the going rate of $\$ 17.00$ per share, this option had a significantly favorable valuation of $\$ 14.3$ million.

Thus, the total amount for all participating employees was approximately $\$ 60$ million, an amazing gain of nearly 450\%! Clearly there were substantial financial advantages to all PSA employees from the merging as well as shareholders. Furthermore, the deal was being touted in the industry as a sweetheart deal for PSA.

In addition to the stock gain, USAir had a reputation of treating its employees fairly. Ed Colodny, chairman and president of USAir Group, had assured PSA that there would be no reduction in wage rates and that PSA would become a part of a growing airline. The same assurances could not have been made if PSA were to have remained independent; in fact, wage concessions and cutbacks had been discussed for several months prior to December 8 , 1986 .

As an added positive influence, USAir had one of the strongest balance sheets in the entire airline industry and the route systems of PSA and USAir would certainly complement one another.

Despite the significant financial stock and trust 
related advantages for every PSA employee, despite the fact that wage reductions would not occur with USAir as they would have with the struggling PSA, despite the growth opportunities that existed with a larger and stronger organization and despite the history of fair treatment for all individuals within the company, PSA employees experienced a loss that permeated the halls, offices, crew lounges, ramp areas and aircraft cockpits and gallies system wide.

The senior managers of the organization knew that tactics and strategies needed to be developed and implemented in order to better facilitate the change process that was now a reality.

The Change strategy

Initiated by president Russell Ray, a change strategy was developed. This researcher was an integral part of the development and execution of the change plan.

Chapter $V$, then, is set up in five main categories. Each category is described now from a general overview perspective and then broken out independently in greater detail.

The first category has been labeled as "The Internal Mechanisms for Articulating Change." What this means is that there were specific communications vehicles established within the organization exclusively to keep employees informed about the merger. The directors believed that if information could continue to flow in a 
consistent fashion throughout the company, some of the uncertainty about the acquisition process would be removed, thereby allowing employees to focus on their jobs as opposed to rumors. The communications vehicles which were used internally to articulate the events related to the change were PSA News Update and the newly designed PSA USAir Merger Update. Each of these communications were released systemwide several times each week between December 8, 1986 and May 29, 1987. The communications will be described and analyzed as they flowed chronologically throughout the organization. How these communications related to some of the models of change will also be highlighted as appropriate.

The second category has been labeled "The External Mechanisms for Articulating Change." This category included a collection of articles that were published in a variety of newspapers between December 8, 1986 and May 29, 1987. These articles were also disseminated inside the organization so that employees would also have the view from the external environment as to how the merger was progressing. Called press packets, the articles from many different cities, but mostly in the PSA route system, were important since they offered views that were often different than that of the employees and managers. The news articles will be described and analyzed as they flowed chronologically, and they will be related to the specific models of change as applicable. 
The third category of change action has been called "Programmatic Processes." This action was simply a series of training workshops or interventions which were designed for the managers of PSA to help maximize understanding and to help minimize expected productivity declines. Because many managers in particular were having a difficult time shifting their loyalties from PSA to USAir and because their support and confidence were essential to the business, this intensive program was geared to the unfreezing process. This change category in particular was initiated, designed and implemented by the researcher and will be fully described, identifying the change models as warranted.

The fourth category has been titled "The Impacting Leader Actions." Some actions were taken by President Russell Ray so that he could assist in a smooth transition for employees and for the business. The deliberate and planned actions that were taken by Ray from December 8 , 1986 through May 29, 1987 will be described. The manner in which these actions intertwine with the five models of change will also be captured.

The last category is simply called "Employee Views." All of the computer communications among employees throughout the system had been collected. It was common for employees to communicate back and forth over a computer network called the SCS system. This is a computer system which means stations Communications 
System. Commonly referred to as computer chatter, this grassmroots feedback is essential to describe as an integral part of the change process. The employee views provide the feedback loop that is so necessary in all change strategies. This category allows some measurement of the resistance and/or acceptance to the change and the strategic change actions. This descriptive analysis will also reveal the relationship of the employee feedback to the models of change.

This chapter, then, is a descriptive analysis of these significant elements or actions that occurred during the change cycle. The way in which these elements connect with the five primary models of change will also be analyzed. The approach will be to first describe fully the specific outputs which were paramount in each change action category and then determine which model of change best relates to that output.

A complete qualitative trend analysis of which change models appeared predominant, and why, will take place in Chapter VI.

\section{Internal Mechanisms for Articulating Change}

There were two key internal mechanisms which were used to communicate the process of the acquisition. The first was a vehicle calle:d PSA News Update. This communications vehicle had been in place at PSA for several years and was designed to quickly overview significant news items within the company and within the 
industry. The distribution of this document spanned the entire company. Hard copy or paper copy of this document went to all PSA locations, and the news was also delivered to employees via the computer communications system. Every employee had access to this information.

The second communications vehicle was specifically implemented to complement PSA News Update, but also to provide more responsive and detailed information regarding the merger. It was called PSA USAir Merger Update. A comprehensive collection of all these releases was captured from the time period of December 9, 1986 through May 29, 1987. This period of time represents the day after the agreement to acquire was reached through the day when the acquisition was legally and officially consummated.

Immediately after the December 8, 1986 announcement of the agreement to acquire PSA, an intervention was planned and communicated. The December 9, 1986 PSA News Update announced that USAir Group, Inc. Chairman Edwin Colodny would be at PSA headquarters in three days for a series of informal meetings with employees. As seen in Figure 3, the visits were planned to reach employees from seven different work groups in six separate interventions. This first step to meet the chairman of their new company was designed to establish comfort while in transition for PSA employees. This action specifically has a relationship to the systems-organic model of change, 


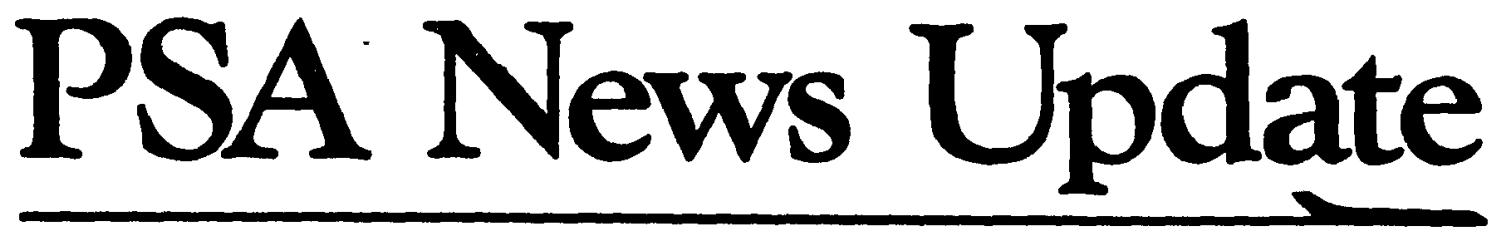

December 9, 1986

Volume 4, Number 94

USAIR CHAIRMAN MEETS PSA EMPLOYEES THURS.

USAlr Group Inc. Chairman Edwin Colodny will be in

San Diego Thursday for a series of informal

meetings with employees throughout the day. His schedule of department visits is as follows:

- Maintenance; in the shop; $7 \mathrm{a} \cdot \mathrm{m}$.

- Accounting; in the accounting dept.; 7:30 a.m.

- Flight and Inflight, Plight crew lounge; $11 \mathrm{a.m}$.

- Res./Training Center; res. cafeteria; 2 p.m.

- Airmotive; in the shop; $3: 15 \mathrm{p} . \mathrm{m}$.

- Admindstrative staff; SANMO atrium; 4:30 p.m.

PSA REPORTS RECORD NOVEMBER TRAFFIC

PSA reported record November scheduled trappic results. During November, PSA carried 836,000 passengers, compared to 800,000 in November 1985. PSA carried $9.9 \mathrm{milli}$ ion passengers for the the first 11 months of the year, compared to 8.3 mililon for the same period in 1985.

RPMs for November were 326 million, up 5 percent over the same month in 1985. RPMs for the 11 months were 4 billion, up 23.6 percent. ASMs for November were 629.6 million, up 18.5 percent, while ASMs for the 11 months were up 23.2 percent over the first 11 months of 1985 to 7 billion. November load factor was 51.7 percent, compared to 58.4 percent Por November 1985, while the load factor for the first 11 months was 56.5 percent, up from 56.3 percent for the first 11 months of last year.

ATC UPOATE

Last week (Dec, $1-7$ ) based on zero time, 35.9 percent of PSA flights were affected by als traffic control delays.

Figure 3. Announcement of the first intervention with USAir Chairman Ed Colodny. PSA News Update, December 9, 1986 . 
because the intervention was planned to both communicate to employees and to get their feedback.

The next day, December 10, 1986, the first PSA USAix Merger Update was released. Issue number one was symbolic of the company's continuing desire to communicate with the employees and the company's need to begin using the names PSA and USAir together. Additionally, the format of this communication, which was designed in question and answer style, stressed the company's focus on being responsive to individual concerns.

The types of questions that were dominant very early dealt with the purchase of stock options, the Profit Sharing Plan (PSP) and trust. Figure 4 exemplifies the style and format of this communications vehicle. From a framework of the personal therapeutic model of change and the systems organic model of change, this obvious conviction for the individual prevails when viewing the PSA USAir Merger Update. The question and answer format implies interaction, which has the intent of helping the people in the organization learn.

In fact, on December 12, 1986, employees were informed that anyone with a questions should contact his or her immediate supervisor or the corporate communications department. Interaction, intervention and feedback were playing vital roles in the change action. The commitment to communicate was an important symbol as well. Only four days after the announced agreement to 


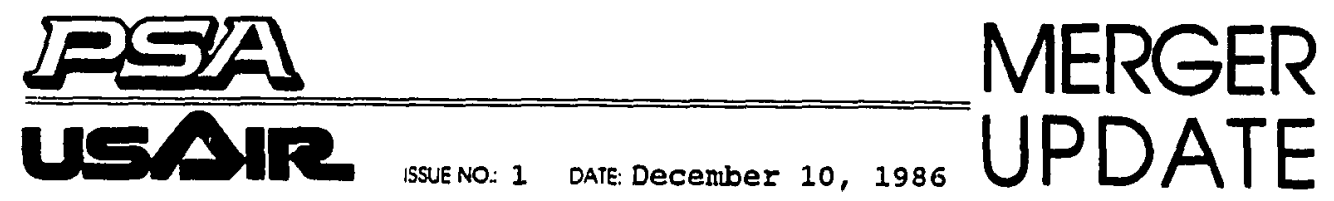

The proposed merger between PSA and USAir has raised a number of questions from employees. Merger Update will be published as needed to answer these questions and to address related issues. These questions are answered by members of PSA management who have the knowledge or information to provide the answers.

Q: In the announcement to employees, we were told about an "option." What option do employees have to buy $1,643,100$ shares at $\$ 8.33$ per share?

A: At the time the PSP program was put into effect in December 1984, all employees were provided with a right to purchase additional airline shares. Various letter agreements with employee representatives and the statement of policy with the noncontract employees provided that the profit sharing plans as directed by the PSP committees - could buy 547,700 shares of airline stock at $\$ 25$ per share. Because of the three-for-one Airline stock split, that equates to $1,643,100$ shares at $\$ 8.33$ per share. The various PSP agreements provided that the option be exercised by the plans (PSP committees) upon payment in cash of the purchase price - the total purchase price being $\$ 8.33$ times $1,643,100$ or $\$ 13,687,023$.

In our USAir agreement, we are to be paid $\$ 17$ for each of these shares, or a total of $\$ 27,932,700$. Rather than require us to raise the $\$ 13.6$ million dollars to receive $\$ 27.9$ million upon the merger with USAir, we have been promised that we will be paid the difference between $\$ 13.6$ million and $\$ 27.9$ million the gain or profit - by way of a contribution to the PSP trust in the total amount of $\$ 14.3$ million.

Q: Do I have to do anything to exercise this option?

A: No. When USAir completes the purchase of our stock, this contribution of $\$ 14.3$ million will be made without anything further required of us or our PSP committees.

Figure 4. The first release of the new PSA USAir Merger Update, December 10, 1986. 
merge with PSA, the company had blitzed several communication media.

On December 16, 1986 the PSA News Update spotlighted a videotaped holiday message from PSA President Russell Ray. The tape was sent to all locations that same day and it addressed a number of important matters including Ray's support for the pending acquisition. Called a holiday message, this communication emphasized the symbolic and cultural aspects of the situation.

The questions from employees on the December 19, 1986 PSA USAir Merger Update expressed concern about the status of their departments and jobs. Emotionalism was in the air. Ambiguity was getting high. It was important that the individual questions were answered factually and rationally. (See Figure 5.)

In the January 9, 1987 PSA USAir Merger Update the questions moved from emotionally passive to emotionally assertive (see Figure 6); doubt was expressed in a very subtle way as sensed in the following questions:

1. Is it possible for employees to review the PSA/USAir Group, Inc. Merger Agreement filed with the Department of Transportation? If so, how may we review it?

2. What steps are involved in the merger of PSA and USAir?

3. How can we get immediate answers to our questions about the merger? 


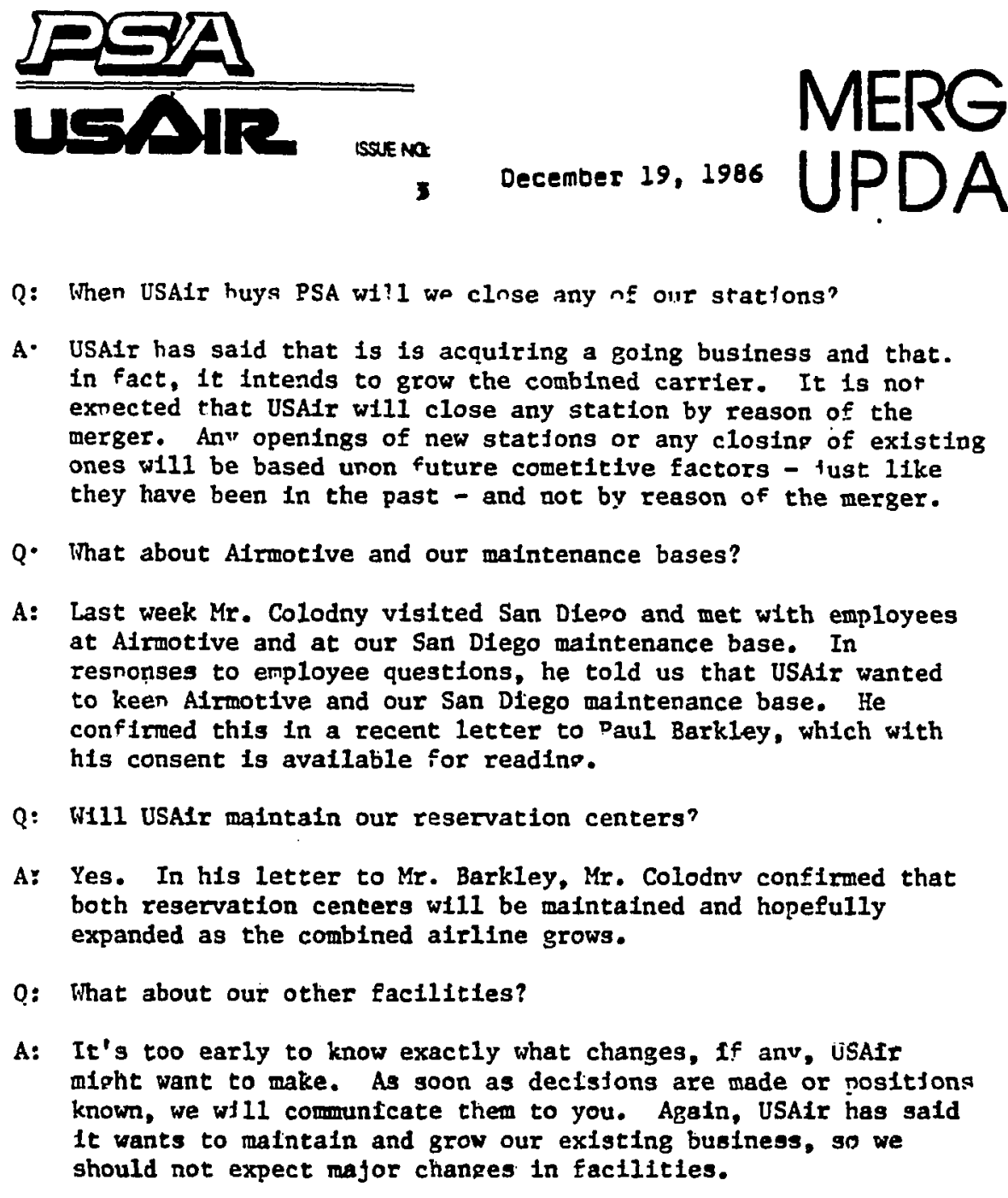

\footnotetext{
Figure 5. Concerns expressed by employees regarding the status of their departments within the company. PSA USAix Merger Update, December 19, 1986.
} 


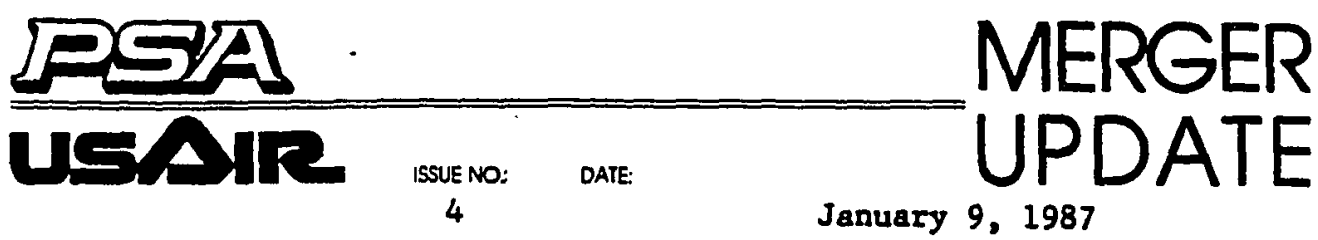

Q: Is it posstble for employeen to review the PSA/USAIr Group, Inc. Merger Agreement filed with the Department of Transportation? If 60 , how may we review $1 t$ ?

A: As indicated in the letter dated December 8, 1986 which employees recelved at their home addresses, the Merger Agreement was sent to union representatives via Certified Mail on December 11. For noncontract employees, each nember of the PSP noncontract committee has also recelved a copy. In adition, copies of the Application filed with the Department of Transportation, which includes the Merger Agreement, are being sent today to locations throughout the PSA system, making it more convenient for employees to review the documents. These locations are listed on the attached page.

Q: What steps are Involved In the merger of PSA and USAir?

A: We are currently in what we call "Stage I" of the merger. Although the Merger Agreement has been signed and the announcement of the proposed merger has been made, there are conditions which must be met before the sale to USAir Group, Inc. can be completed. As stated in the announcement of December 8, 1986, these cond1tions include stockholders approval, government approvals, and union approvals to amending certain merger and acquisition provisions in collective bargaining agreements. Assuming these conditions are met, which we anticlpate to be during the first quarter of this year, we will enter "Stage 2." In this stage, USAir Group actually owas PSA but PSA will be operating under Its own name as a wholly-owned subsidiary of USAir Group. The PSA collective bargalning agreements now in effect will continue to be applied and each PSA union will continue its representation. The final otage, "Stage 3," will occur when the operations of PSA and USAIr are actualiy integrated into one operation. The actual timing of this stage is not known, but will be after Integration plans have been fully developed and reviewed with each employee group or their union representatives.

Q: How can we get immediate answers to our questions obout the merger?

A: There are many more questions at this point than there are answers simply because it 18 st11l too early in the process to know exactly how and when PSA and USAIr operations will be integrated. However, to ald in the communlcatlons, the corporate communicetions department at SANMO will be Installing by mld-January a two-way answering machine as part of the Employee News Hotline. Employees may call SAMMO extension 2126 and record any question they may have. The questions will be monitored on a daily basis, and callere may request a personal response by leaving their name and phone number. More frequently asked questions will continue to be pubilshed in Merger Update.

Figure 6. More assertive questions from the employees of PSA. PSA USAir Merger Update, January 9, 1987. 
The desire to communicate from a personal-therapeutic and systems-organic perspective gleans through from the following response from Figure 6:

There are many more questions at this point than there are answers simply because it is still too early in the process to know exactly how and when PSA and USAir operations will be integrated. However, to aid in the communications, the corporate communications department at SANMO will be installing by mid-January a two-way answering machine as part of the Employee News Hotline. Employees may call SANMO extension 2126 and record any question they may have. The questions will be monitored on a daily basis and callers may request a personal response by leaving their name and phone number.

The managers continued their efforts to demonstrate that the company was there to listen. PSA cared about what the employees needed to ask and that communication response would be accurate, honest and consistent.

A political view became evident in the January 13 , 1987 PSA USAir Merger Update (Figure 7). A variety of different questions pertaining to special interest groups emerged. The different groups or people mentioned were the Department of Transportation, the Teamsters, PSA company officers and USAir Group Chairman and President Ed Colodny. Of particular interest is the slight appearance of union unrest as inferred in these two questions: 


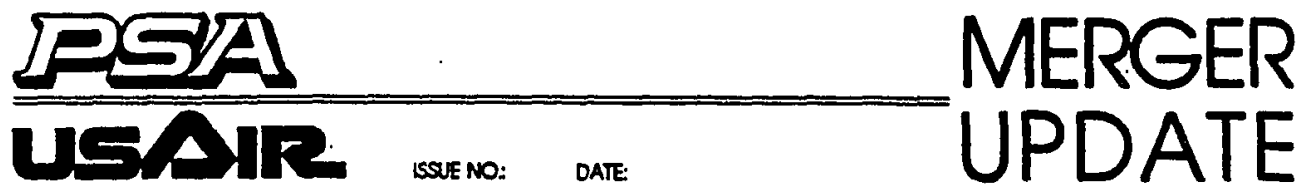

$5 \quad$ January 13,1987

Q: To date, what has happened in the proceedings before the Department of Transportation (DOT)?

A: Last week, DOT approved a voting trust allowing USAIr Group to gain a 51 percent interest in the voting stock of PSA. This is a normal step in the DOT process concerning acquisitions of this type.

Q: In a letter to employees, the Teamsters claim PSA officers have been receiving bonuses while the PSA employees were taking pay cuts. Is this true?

A: As agreed upon in 1984 collective bargaining, there have been no bonuses paid to offlcers. The officers of PSA took a 15 percent pay cut and have been subject to the same wage iimitations as all other PSA employees.

Q: Have the representatives of the collective bargaining groups been given the proposal for the amendments to the merger and successor provisions of the PSA labor contracts required by USAIr?

A: Yes. On Dec. 8, meetings were held with representatives from each bargaining unit to descrtbe the terms of the proposed merger. During these meetings the proposed amendments to the PSA labor agreements were described generally. Since then, additional meetings have been held with the representatives of each PSA labor group. At these neet1ngs, PSA has submitted written proposals containing the language regarding the changes to the merger and successor provisions in the labor contracts required under the acquisition agreement. The next step is to gain approval for these changes from each group.

Q: We understand Mr. Colodny was in Northern California last week. What was the purpose of his visit?

A: USAIr Group chairman and president Edwin Colodny was in San Francisco and Sacramento lase week on courtesy calls to a number of state and local officiala. In addition, he paid a vielt to our San Erancieco otation and matntenance base to introduce himself and visit with eaployees.

Figure 7. Interest groups emerge. PSA USAir Merger

Update, January $13,1987$. 
1. In a letter to employees, the Teamsters claim PSA officers were receiving bonuses while the PSA employees were taking pay cuts. Is this true?

2. Have the representatives of the collective bargaining groups been given the proposal for the amendments to the merger and successor provisions of the PSA labor contracts required by USAir?

Both of these questions addressed the Teamsters organization as an action channel. It was at this point that the weaving in of the political-economic model began. On January 20,1987 , the two-way hotline communication device was inaugurated. The PSA News Update of that same date said:

The PSA News Hotline is now set up to record employee questions regarding the pending merger with USAir. The Hotline's SANMO extension is still 2126. When employees call the Hotline, they will hear the regular recorded message, which is updated on Tuesdays and Fridays. Following the message, callers will hear a beep and will then have 30 seconds to record any merger questions they have. The Hotline will be monitored daily and employees seeking a personal response should leave their names and phone numbers. Frequently asked questions will continue to be answered in the PSA/USAir Merger Update. Again, the managers' desire to give as much information to employees as possible and to get as many 
questions and concerns from employees as possible, was beginning to be a consistent theme during this change process.

On January 20, 1987 the senior managers communicated that the Board of Directors of both USAir Group Inc. and PSA set March 17, 1987 as the date for holding a special meeting of stockholders at which the acquisition of PSA by USAir Group would be presented for approval. Employees were advised that if they were current participants in the Profit Sharing Plan and Trust (PSP) that they would be entitled to vote their shares in the PSP Trust by proxy. Further, employees were informed that this would be the only guaranteed opportunity provided to employees to vote on the pending acquisition of PSA by USAir Group. This advance notice was not necessary, yet senior managers thought that employees needed to know in advance of their right to vote.

On January 22,1987 , in a politically symbolic move, PSA and the Master Executive Council of the PSA pilots represented by the Airline Pilots Association announced that an agreement modifying the Pilots' stock and Profit Sharing Plan Agreement and the merger and successor provisions of their collective bargaining agreement had been reached. The key aspects of the agreement are indicated in Figure 8.

Pilots by tradition tend to be viewed within the airline industry as the leaders and policy setters. 


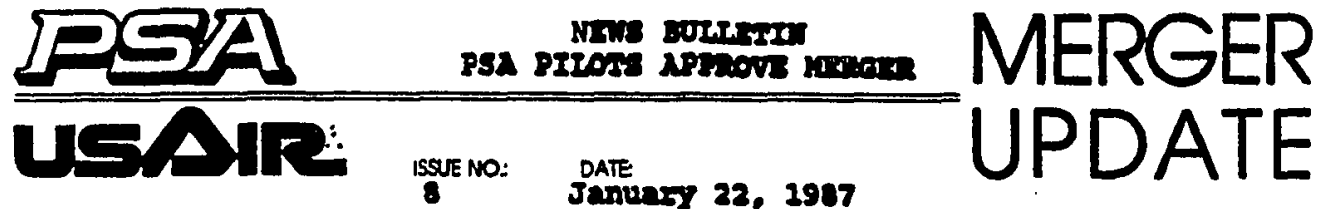

Today PSA and the Manter Executtve Couned, of the P8A pllote

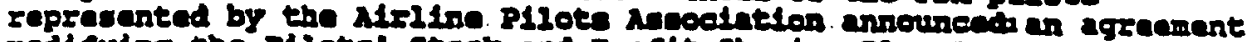
modify ing the p1lote' stock and proste staring plas Arreanent and the merger and ouceansor provistoris of the collective Bargaining Agreement batween PSA and the pilots. USAt has advined PSA that the agreament with the pilote meete. the conditlons of the PSA-USAIr agreanant to closing the acquideltion of pan by oshis-Group, Ine.

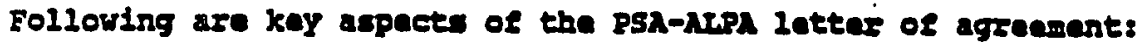

1. Agreament to recelve cabb equai to $\$ 17$ per share for al1 rameining company contzibution, and to zecelve canh in the amount of $\$ 8.67$ par share (the opread betwean the option price of $\$ 8.33$ and $\$ 27$ upon exaretse of the XIPA portion of the "Option shares." (AII shares already held in the pilots' PSP will be converted to calh at $\$ 17$ por share purauant to the PSA-USAIr agrenment.)

2. Walver of the right of first cotusal to purebese PSA as it relates to the USA1r offer.

3. Agreament to sattle the diaputi over the originel 15 t contribution by racelpt of $\$ 27$ por share for each of the "disputed shares" and watver of any eladm assoclated with contributions of shares to the PSP.

4. Agreement provides lor saniority Integration before USAir Group alfects an integration of the operations, facilities and employees of PSA and USAix, Ine., provided the seniority integration process 10 completed before July 1, 1987: :

5. Agreanent to waive application of certein merger and succestor language in their contract as they apply to the usAir transaction.

6. Agremant that the pilote w11l recelve labor protective provisions (LPP's) eguivalent to Aleghany/Mobawk IPP's.

7. Agremant that the terns of the lettar of agreanent satisfy PSA' ' duty to negotiate vith the Pan pilote ralative to the proposed merger.

PSA is continuing to negotiate elmilar agranents with the southwest D1spatchers Assoctation, and the Southwent Crew Controllers Association, and PSA is continuing to meet with the Non-Contract comitten. PSA expects to commence eindlar difeursion in the noar future with the raanters.

Figure 8. Pilot union approves merger. PSA USAir Merger Update, January 22, 1987. 
Typically, their way of thinking and acting sets the stage as to how other groups typically think and act. It is no surprise, then, that this announcement, which came so quickly, was intended to shift any anti-agreement thinking and any tactical delays in negotiating. In fact, this Merger Update ends with a statement of hope. PSA is continuing to negotiate similar agreements with the Southwest Dispatchers Associates and the Southwest Crew Controllers Association, and PSA is continuing to meet with the non-contract committee. PSA expects to commence similar discussions in the near future with the Teamsters.

On January 23, 1987, the PSA News Update reported that the USAir Group posted a net income of $\$ 1.8$ billion and operating income of $\$ 169.4$ million for the year 1986 . Although factual, this type of information startled employees who were not used to being associated with a company with net income figures in the billions.

In that same update employees were informed that the PSA News Hotline was available with information and for individual questions. This constant and consistent message of PSA wanting to communicate with employees is once again noteworthy.

The January 26, 1987 Merger Update tended to be more philosophical in nature (see Figure 9). It almost appeared as if there was a need to sell the merger to employees, stressing that the acquisition was very 


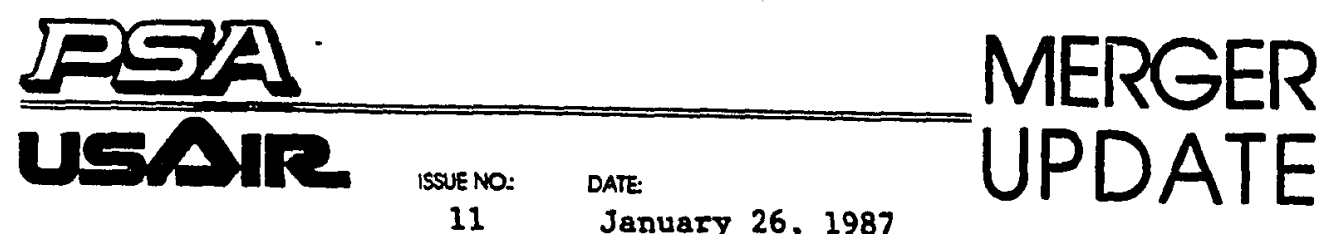

11 January 26,1987

Q: Why does USAIr Group belleve that the comblnation of PSA and USAIr will be able to compete effectively with the mege-carriers?

A: It is important to remember that USAIr Group has been profitable for 10 years and has one of the strongest balance sheets in the alrline Industry. It has already demonstrated on 1ts own, a capacity to compete with the mega-carriers in the east. Based on Its expertence and firm financial foundation, a combination with PSA, a dominant carrier on the West Coast, and USAIr, a dominant carrler on the East Coast, provides the merged airline an obvious opportunity for additional growth and better fleet utililzation. USAir Chairman and President Edwin Colodny, during his Dec. Il visit to PSA, reiterated to PSA employees that USAIr Group Intends to contInue expanding the airline after the merger. Relative to the other merger candidates in the industry, PSA's board of directors believes that the combined carrler w1ll be a dominant player in the industry and will be much more capable of fending off unfilendly competitors than PSA would be on its own.

Q: What have the independent financlal analysts who follow the airline industry said about the merger?

A: The following are printed quotations from noted analysts commenting about the USAIr-PSA merger.

Louis Marckesano, Janney, Montgomery, Scott: "If 'I was an employee at PSA, I'd be dancing. USÁl工 is one of the highest paid alrines in the country and now (the employees are) In an organization with a lictie more financial stability" (Sacramento Bee, 12/9/86).

Mike Derchin, First Boston Securities: The merger "gives both alrlines the opportunity to become east-west carriers" (New York Times, 12/9/87).

George James, Alr Line Economics Inc.: "For long-term survival, they've got to do this" (USA Today, 12/9/86).

Bob Joedicke, Shearson Lehman Brothers: The merger "develops a latger critical mass and achleves a certain awount of what is called the barbell effect" (Weshington Post, 12/9/86).

Figure 9. Persuasive communication based on the belief that the merger was positive. PSA USAir Merger Update, January $26,1987$. 
positive. The first question in that update dealt with why USAir believed that the combination of PSA and USAir would result in the ability to compete effectively with the mega-carriers. The response to this question was answered in a fashion that reflects beliefs and ideals. This persuasive language hits at the cultural symbolic model of change.

The question was answered a second time by giving favorable reviews of the merger from the financial pages of several important newspapers. This entire communication was editorial in scope and was essentially persuasive in tone. The message was clear: The merger was a positive event; it was good news!

The next day, January 27, there was more positive news in the PSA News Update. This document announced that USAir had committed itself to an extension of the labor protective provisions that the employees of PSA and USAir enjoyed should the merger be consummated. Iabor protective provisions are the practices and policies that are in place to protect employees through compensation should their jobs be lost or displaced in the event of a merger.

That same day, the PSA USAir Merger Update reiterated the fact that President Ed Colodny had delivered to USAir employees a written commitment to extend to all USAir and PSA nonofficer personnel the standard Allegheny/Mohawk labor protective provisions (LPPs). In the letter, 
Colodny noted that standard LPPs provide for economic benefits to those employees adversely affected by the merger and include relocation assistance for all employees who may be required to relocate their residences as a result of the merger (see Figure 10 ).

On January 30, the PSA News Update announced that nine meetings would be set up during the next week in a variety of locations so that employees could get answers to their questions regarding the profit sharing plan and the labor protective provisions. These interventions reflect the systems-organic model of change. The meetings were intended to be open forums where employees could express their views as well as request information that they may need in order to properly vote for or against the merger.

February 10, 1987 was a day of mixed communication messages. The first message advised employees that a letter had been mailed to the homes of all employees which provided an estimate of the profit sharing plan account value of each employee. This would give the employee a baseline as to how much money he or she would personally receive after the merger.

The next message that day was one which promoted the cultural-symbolic model of change. Buttons were released to all employees in all locations which read "USAir-PSA Smiles Coast to Coast." These buttons were intended to be symbols of the transition from PSA to USAir for both 


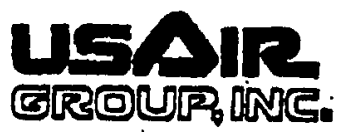

$\because \quad-\therefore$

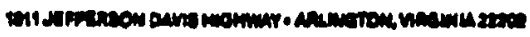

Jenuaxy 27,1987

To the USAit Jaployeces

During the peef month, I have hid convergations with waby of you about

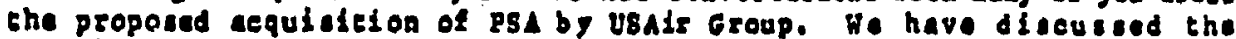
exciting prospecs which a oubsequent merger of USAir and PSA vould bring. Ae 1. antural in any merger, eeeb of you utli have quectone ebout job securicy. Thlo letcer is inceoded to addrens oueb concerse.

Masy of our amployens vare lavolved In earlier mercers witb lake cantral Airllace and Hobrit Airlines. Both mezgers vere importane to the growth of our company asd to the suceese we have enjoyed. In both the rohawk and lake Ceotrel tranaction, labor protective previsions ("LFP'g") were axtended to the employaes of the wo cerrlers.

U8Ais believes is is appopsiate to nake a combltment to axtend to ell

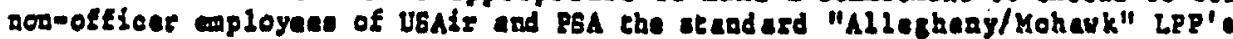
at such time an there 10 a marger of UsAlr and PSA. In tuture coumudications, we will be providirs more detailed explanations of these LPP's. Is eumenzy, they provide econcole besefice to exployens whe may be adversely affeeted by a merger, provide tor relocation achiatance to mployase who ere required to change their place of resideoce 10 a reaule of a torger-required transfer, and artabliab procedurae tor the fair and equitable incegration of seaiority. Thay aleo provide chat all dieagremente over tho application of these beattice will be fairly resolved by bindiae arbltration.

As you heve all read, certals mattere heve to be resolvad before USAir Group cen ecquize PBA and procend vith plane co combine the two atrilinat. Regulatory epproval is neceseary, a vall as the meceostul outcono of discusaloas betwean PSA ard the labor orgagizations represened ing ite axployees. He are optiwietic that Group vill be able to go forverd vitb the acquieftion of PBA, is voll as the ultimate enger of the two aiglines. The LPP' vill be lmpleanted whan USAir and PSA are marged into oca carrier. .

sinceraly.

Figure 10. Ed Colodny's letter to USAir employees. January $27,1987$. 
employees and customers. A symbol of two airlines coming together by way of a button-wearing ritual focuses on the cultural implications of this change action.

Later that same day the news was released in the PSA USAir Merger Update that noncontract employees had voted to approve the merger. Now two groups were officially in favor of the acquisition, the pilot group and all noncontract employees. The special interest groups in favor of the merger were growing, but there were still opposing coalitions with which the managers had to deal.

A political focus was emerging as the voting groups aligned in favor of the merger. There was concern over whether or not the Teamster group would come to an agreement. In the February 11 issue of PSA USAir Merger Update, employee questions were directed at this concern. Examples of some of the questions asked were:

1. What is the status of meetings between PSA and the Teamsters regarding modification to the labor contracts?

2. The February 6 Teamster Hotline said they will be meeting with company officials. Since USAir has authority for final approval, will they be attending these meetings?

3. What happens if all bargaining groups do not agree to the modifications to the labor contracts? The answers to these questions and others are given in Figure 11 . 


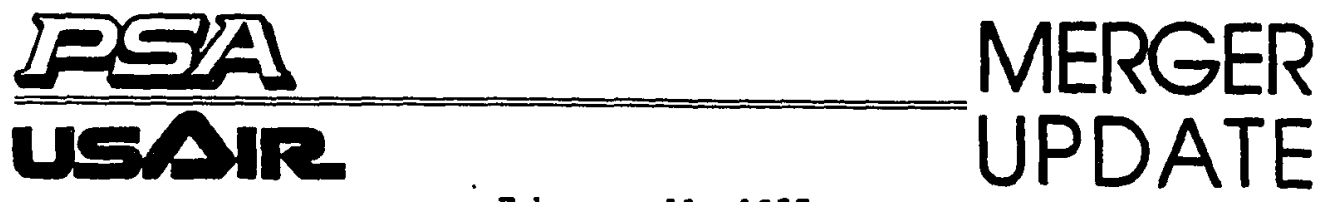

February 11,1987

Q: What is the status of meetings between PSA and the Teamsters regarding the required modifications to the labor contracts?

A: Meetings between PSA and the Teamsters have been scheduled for Feb. 16, 17 and 19 in Washington.

Q: The Feb. 6 Teamster Hotline said they will be meeting with company officials, "since USAIr has authority for final approval, it makes sense to have the principals avallable to make the necessary decislons." Will USAlr be attending these meetings?

A: No, there are no plans, nor any reason, for USAIr officials to attend the February weetings. The meetings are being held in Washington at the request of the Teamsters. These meetings will include PSA officials and attorneys, Teamster representatives and Teamster attorneys (who are located in Washington). PSA and the Teamsters must negotiate the contract modifications, not USAIr and the Teamsters.

Q: What is the status of negotiations with other bargaining groups?

A: Talks are continuing with the Southwest Crew Controllers Association and the Southwest Dispatchers Association.

Q: What happens if all bargaining groups do not agree to the modifications to the labor contraces?

A: The merger agreement between PSA and USAIr Group is contingent upon PSA's meeting all USALr Group's requirements for closing the deal, which includes the modifications to the labor contracts. Obviously, all requirements must be wet.

Q: What 18 the status of the integration of the sentority ifsts for the pilots?

A: ALPA meetings between PSA and USAIr are currently underway to Integrate the senlority 1 ists, following ALPA's standard procedures to arrive at a merged seniority 1 ist. According to ALPA represencatives, they expect to have final integrated sentortey list prior to June 14 .

Figure 11. An emerging political focus as voting groups align in favor of the merger. PSA USAir Merger Update, February 11, 1987. 
The meetings between PSA and Teamsters officials were scheduled for the following week. The talks were to be held in Washington, D.C., which is the corporate headquarters of USAir.

On February 17, both PSA News Update and PSA USAir Merger Update released information that still another group had joined the pro merger coalition. The PSA dispatchers who were represented by the southwest Dispatchers Association had announced an agreement. USAir had advised PSA that the agreement with the dispatchers met the conditions of the USAir PSA agreement for closing the acquisition of PSA by USAix Group, Inc. (see Figure 12). This action was significant since now three groups had approved the merger.

Meetings continued during the week between PSA and the Teamsters and discussions also continued with the Southwest Crew Controllers Association. Simultaneously, news was published which reported that PSA losses in 1986 were $\$ 5.1$ million for the fourth quarter and $\$ 3$ million for the year. PS Group Inc., the holding company of PSA, also reported net losses of $\$ 4.8 \mathrm{million}$ for the fourth quarter of the previous year and $\$ 13.9$ million for 1986 .

As March of 1987 began the question and answer format of the PSA USAir Merger Update subsided. Instead, a more narrative style was used which seemed to focus on what groups approved the merger. Certainly, that change reflected that a more political lens was viewing the 


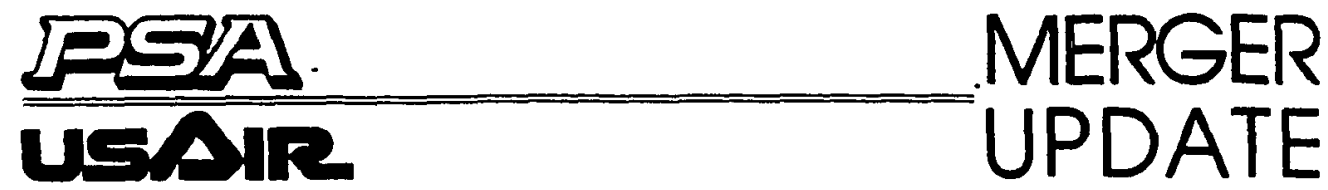

NEWS BULLETIN

February 17, 1987

Number 20

\section{PSA DISPATCHERS APPROVE MERGER}

Today PSA and the PSA dispatchers represented by the Southwest Dispatchers Association announced an agreement modifying the Dispatchers' Stock and Profit Sharing Plan Agreement and the merger and successor provisions of the Collective Bargaining Agreement between PSA and the dispatchers. USAIr has advised PSA that the agreement with the dispatchers meets the conditions of the PSA-USAir agreement to closing the acquisition of PSA by USAir Group, Inc.

Following are key aspects of the PSA - dispatchers letter of egreement:

1. Agreement to receive cash equal to $\$ 17$ per share for all remalning company contributions, and to-recelve cash in the amount of $\$ 8.67$ per share (the spread between the option price of $\$ 8.33$ and $\$ 17$ ) upon exercise of the dispatchers "portion of the "option shares." (Al1 shares already held in the dispatchers' PSP w111 be converted to cash at $\$ 17$ per share pursuant to the PSA - USAIt agreement.)

2. Agreement to settle the dispute over the original 15 percent contribution by recelpt of $\$ 17$ per share for each of the "disputed shares" and waiver of any claing associated with contributions of shares to the PSP.

3. Agreement provides for senforlty integration before USAir Group effects an integration of the operations, facilities and employees of PSA and USAIr, Inc., provided the senlortty integration process is completed before July $1,1987$.

4. Agreement to walve application of certain merger and successor language in the dispatchers' contract as such language applies to the USAIr transection.

5. Agreement that the dispatchers will recelve labor protective provistons (LPPs) equivalent to Allegheny/Mohawk LPPs

6. Agreement that the terms of the letter of agreement satisify PSA's duty to negotiate with the PSA dispatchers relative to the proposed merger.

ALPA and the PSP Non-Contract Commlttee have previously reached agreement with PSA on similar issues. PSA is continuing to negotiate similar agreements with the Southwest Crew Controllers Association, and PSA commenced simllar discussions with the Teamsters on February 16, 1987.

Figure 12. Another work group joins the pro merger coalition. PSA USAir Merger Update, February 17, 1987. 
world and that the merger was moving forward.

On March 5 the United States Department of Transportation approved the merger, and this news was communicated to all employees. That approval completed all necessary government agency reviews.

In related developments, the USAir Group had made an offer to acquire Piedmont Aviation, while almost simultaneously Trans World Airlines had put its bid in for USAir. PSA President Russell Ray said, "Neither TWA's offer to buy USAir Group, nor USAir Group's plans to acquire Piedmont, alters PSA's intent to proceed with the sale to USAir Group: However, these events emphasize the need to obtain agreements with the two remaining [employee] groups as soon as possible in order to close the transactions."

So in the midst of the high ambiguity already affecting the employees of PSA, the TWA and Piedmont news further disrupted the workforce. During early March news and communication focused on USAir's rejection of TWA's acquisition bid and the agreement reached by USAir Group to acquire Piedmont. In fact, on March 10, PSA News Update communicated that Piedmont had agreed to be acquired by USAir Group for $\$ 69$ a share in cash, or approximately $\$ 1.59$ billion. The combination of USAir, Piedmont and PSA would create the nation's fifth largest carrier.

The following day, March 11, PSA crew controllers 
represented by the Southwest Crew Controllers Association approved the merger. The only groups that had not reached agreement were the Teamsters and the shareholders of PSA and PS Group.

Five days later, on March 16, the shareholders of Pacific Southwest Airlines voted to approve the acquisition, with $91.1 \%$ of the eligible shareholders voting in favor of the merger. Of the employee votes, $98 \%$ of the shares voting were in favor of the acquisition. In addition, the PS Group shareholders approved the acquisition with $65.3 \%$ of the stockholders voting in favor of the merger.

Iike any other organization, PSA was political in nature. All work groups, shareholders, and government agencies had approved the merger with the exception of the Teamsters. A pro merger coalition was forming and growing.

The Teamsters had been holding out on any approval and during the holding out period they had initiated a lawsuit against PSA. In the lawsuit, the Teamsters sought an order to force PSA to arbitrate four grievances concerning PSA's failure to force USAir Group to assume the obligations contained in the "Mergers, Consolidations and Acquisitions" articles of the PSA-Teamsters collective bargaining agreement. This tactic by the Teamsters was designed to put pressure on PSA and USAir and to stall the agreement process in the hope of gaining more power. 
PSA had declined to arbitrate the grievances on the grounds that the obligations contained in the merger articles involved issues of representation after the merger took place. This dispute raised post merger representation issues which PSA felt should be dealt with at the National Mediation Board and which the Teamsters felt should be dealt with in federal courts.

The federal court ruled in favor of PSA and dismissed the teamster lawsuit. Communication of this significant action was captured in the March 24 Merger Update (see Figure 13).

In an effort to speed up the approval process by the Teamsters, the senior officers communicated on March 24, that the boards of directors of the USAir Group, PS Group, and Pacific Southwest Airlines agreed to move forward the date for the acquisition to be completed. This tactical move put pressure back on the Teamsters as the union engaged in stalling strategies. A push and pull political relationship had evolved between PSA and the Teamster organization. Conflict was high and many employees were anxious. In the event the acquisition did not take place on April 30, 1987, either party would have the right to terminate the agreement. Paul Barkley, Chairman of PSA said, "The move of the deadline should not prevent the Teamsters from reaching a final decision on the proposed modifications and should give all parties sufficient time to consummate the acquisition without diverting attention 


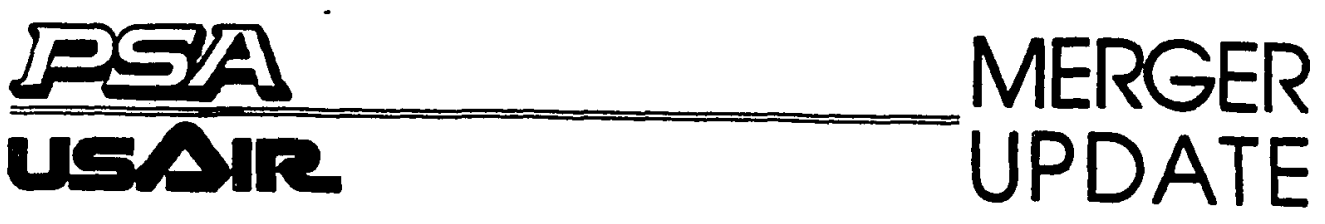

\author{
March 24, 1987 \\ Number 28 \\ EEDERAT COURT DTSMTSSES TEAYSTER IAYSUTT
}

A U.S. Distriet Court in San Francisco has iseued a written order dismissing the complaint against pSA by the International Brotherhood of Teamiere.

In the lawnuit, the Teamuters mought an order to force PSA to arbitrate the tour "grievances" Illed concerning PSA's Failure to force USAir Group to assume the obligatione contained in the "Mergers, Coneolidatione and Acquiattion:" articles of each PSA-Teamster collective bargaining agreement.

PSA had declined to arbltrate those "grievances" on the grounde that the obligations contained in the morger articles involvad clear issues of coployee representation after the merger and were, therefore, not isues that an arbitrator had authority to address. PSA's poeition was that the inoue of representation was a matter for the National Madiation Board. PSA's legal position relative to the enforcement of the merger articles, as communicated to the court, was consiatent with the position it outlined to the reamsters when the language of these articles were being negotiated in 1984 . In this regard, the preamble in ach of the Teamster merger articles states: "The obligations contained herein are subject to the acts and obligations not being in violation of the labor law..."

"There is no question that this dispute raises post-merger representation issues over which the court has no jurisdiction..." stated the court, agreeing with psh's position that the dispute is a matter for the National Mediation Board.

The court's ruling meane that the Teamstere are tree to seek an election of USAir employees after the merger, uppervised by the National Mediation Board. USA1r Group has stated it does not object to Teameter represantation of its employees as long as employees have the opportunity to vote in a falr election.

It is anticipated that the Teansters will appen the District Court's decision. However, UsAlr Group'g position regarding the neceseary medificetions to the Psi-Teangter collective bargeining agraenents is not afenated by the court's ruling since the appeal procese could take nonthe or yeare to complete. Even if the District court had ruled in favor or ene Teansters, USAir Group has made it a condition of the acquisition of PSA that the language be modifled. If they are forced by a court to accept the language and the reaneters refuse to modify lt, USAir Group simply will not acquire PSA.

Figure 13. Federal court dismisses Teamster lawsuit. PSA USAir Merger Update, March 24, 1987. 
from day-to-day business."

On April 1, 1987, confusion was everywhere over the action of United States Supreme Court Justice Sandra Day o'Conner regarding the Delta Air Lines - Western Airlines merger and the impact those decisions would have on the pending acquisition of PSA by the USAir Group. That morning, Justice $O^{\prime}$ Conner vacated a ruling by the appeals court that would have blocked the completion of the Delta-Western merger until an arbitrator could rule on the successor clauses within the Teamster and Air Transport Workers contracts with Western. O'Conner's ruling allowed the two carriers to merge that day.

How did this ruling affect the USAir-PSA agreement? The senior officers of PSA communicated on April 1 that the ruling should have no effect because the USAir Group had made it clear in the December 8, 1986 merger agreement that the merger and successor language in the PSA labor contracts MUST be modified before USAir would acquire PSA. If the Teamsters did not agree to modify the contract language as required by USAir to allow the acquisition to be consummated by April 30, 1987, then the USAir Group was free to terminate the agreement. The special interests of the Teamsters were gaining power and influence as the feasibility of the acquisition occurring as planned became more and more vulnerable.

In the PSA USAir Merger Update of April 8, 1987 (see Figure 14) the employees read that the Teamsters had filed 


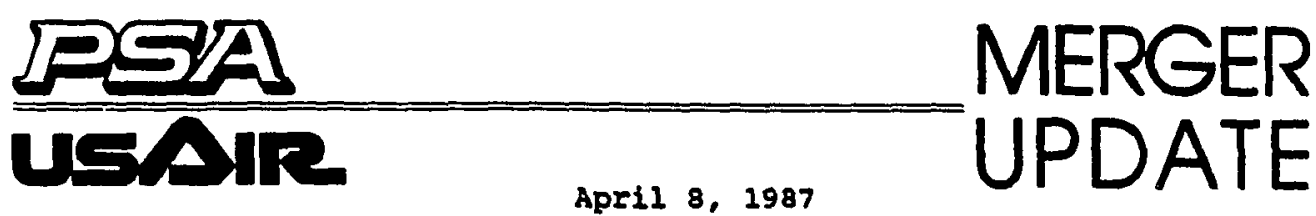

Number 33

TEAYSTERS FITE APREAL

PSA received notice yesterday that the Teamsters have filed an appeal to the court's order handed down on March 24 which dismissed the Teamsters' complaint against PSA. The Teamsters sought an order from the federal district court in San Francisco which would force PSA to arbitrate the four "grievances" concerning PSA's fallure to force USAir Group to assume the obligations contained in the "Hergers, Consolidations and Acquisitions" articles of each PSA - Teamster collective bargaining agreement.

The district court agreed with ESA's position that the obligations in the merger articles contained lsaues of post-merger representation, and therefore were not iseues for arbitration, but isoues for the National Madiation Board to decide. "There is no question that this dispute raises post-merger representation issues over which the court has no jurisdiction," stated the court in its March order.

Despite the outcome of this court case usair Group has made it clear that the mercer and succersor lanotach in all is

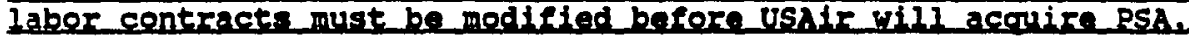
The fact remains that if the Teameters do not agren to modify the contract lanenuag as required by USAlte and allow the geoulisition to be consummated by Aprit 30, 1987 . USAir Group is Eree to terminate the acouisition acrenment.

In a case similar to that between PSA and the Teamsters, the Air Transport Employen union and the International Brotherhood of reameters had tried to force Delta to honor collective bargaining agreement's between Western and its employees that would give the unions continued representation after the merger. Iast Wednesday. Justice Sandra Day o' Connor overruled an order of the appeals court which would have blocked the merger on March 31. Yesterday, according to the Nal1 strest Journal, the full Suprame Court rafused to overturn Justice o'connor's order.

In o'Connor's written opinion stating the reasons for her ruling, she sald that, "...I doubt that respondente' (IBI and Air Transport Employees Union) claims would ultimately prevali... and the applicante (Western, et al) are likely to prevail on the morits..."

Figure 14. The Teamsters appealed the lawsuit and continued the dispute with PSA. PSA USAir Merger Update,

April 8, 1987. 
an appeal. They also read in an underlined paragraph that the Teamsters' delay in agreeing could make the merger vanish. More statements from Justice O'Conner were highlighted as if to bring to light that the Teamsters' move to appeal was indeed a moot point. Reaching consensus was now beginning to be a highly political activity as bargaining continued. There was a reliance upon the Teamsters to use their organizational position as a power tactic, viewed by some as power wielding. At this point, whether one spoke to flight attendants, pilots, dispatchers, mechanics or any other employee of PSA, there was a feeling of frustration as the Teamsters appeared to be stalling and holding out for agreement. Many employees did not entrust the Teamsters with the power and authority to make decisions on their behalf at this point. They felt betrayed by this labor organization.

The Teamsters, on the other hand, were very good at mobilizing resources, and they were gaining the kind of publicity they wanted by resisting USAir's demands for immediate concurrence.

On April 17, 1987, thirteen days before the agreement deadline imposed by the USAir Group, PSA announced in both the PSA News Update and PSA USAir Merger Update that negotiations with Teamsters Local 2707 had recessed without agreement on the required modifications to certain provisions of the PSA-Teamsters collective bargaining agreement. 
At issue were three demands made by the Teamsters that remained unresolved: that PSA "snap back" certain benefits and work rules that were in effect prior to the 1984 contract; that PSA Teamster employees achieve immediate wage parity with USAir employees on the date of the merger; and that PSA establish a $\$ 5$ million trust fund to be administered by the Teamsters.

PSA rejected the Teamster demands, saying that the "snap back" demand was unrealistic and unfair in light of all the stock and employee protection provisions already contained in the PSA proposals, and that raising the "snap back" issue this late in the negotiations was counterproductive. PSA, using its action channels, quoted USAir spokesperson Gene Anderson as saying, "USAir will walk away from the proposed merger if it is not completed by April 30."

A summary of PSA proposals presented during negotiations during March 17 through April 10 was communicated to all employees by senior managers on April 17 (see Figure 15).

Then, the April 20 in the PSA USAir Merger Update stated that the Teamster Iocal 2707 had announced that it would not submit PSA's final contract proposal to its members for a ratification vote.

Between April 20 and April 28, employees began to manifest their anger at the Teamsters. Questions were being raised in the communication chronicle that reflected 
SUMARRY OF PSA PROPOSALS

(March 17 through April 10, 1987)

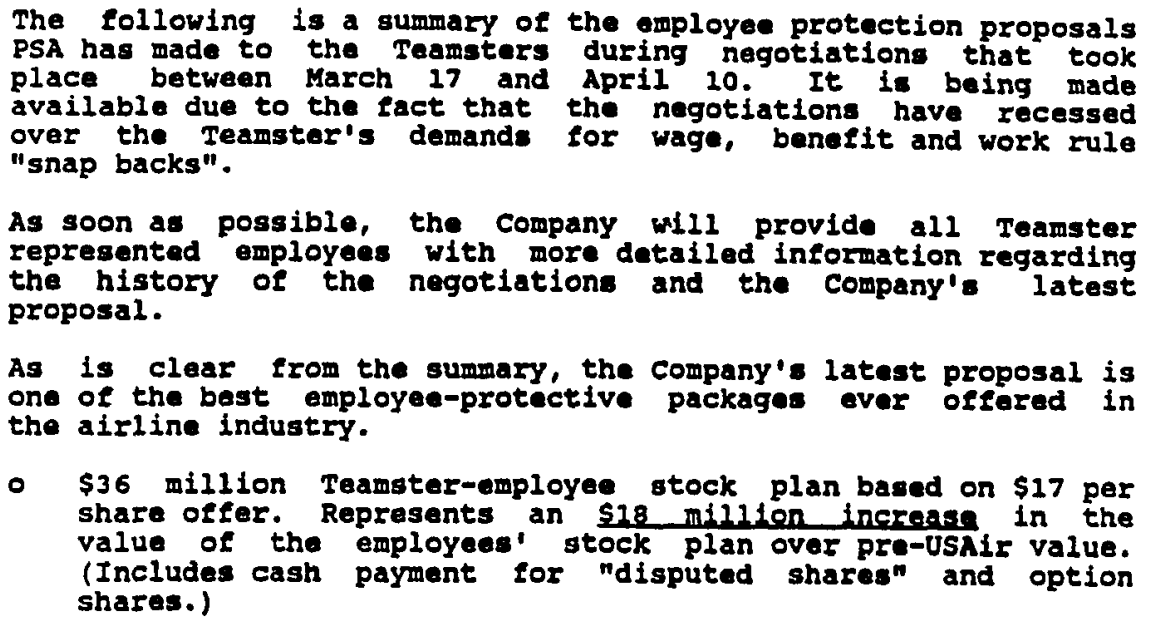

- Alleqheny-Mohawk LPP's to Teamster-represented employees FOr PSA-USAir and USAIT-Piedwont mergers, LPP's include:

(1) "fafr and equitable" seniority list integration;

(2) Severance pay for employees who are not offered USAir jobs :

(3) moving expenses; and

(4) displacement allowances.

- A "no wage rate reduction" guarantee.

- Pay and benefit protection for Teamster-represented employees engaged in seniority list integration activities.

- "No furlough" protection through December 31, 1987.

- Base, domiclie or station closure protection through December 31, 1987.

- Agreement not to merge PSA and USAIr before December 31 , 1987 in order to provide time for the integration of seniority lists.

- \$1.6 million Supplemental Severance and outplacement Trust Fund to be administered by the reamsters and supervised by three (3) independent trustees. Supplemental severance pay to be available to Teamster-reprasanted PSA employees who do not accept USAir job offers requiring relocation to cities outside of PSA's current system. (Provides severance benefit not otherwise available under LPP's.)

- USAir will agree in writing to assume PSA's liabllity for the employee banefits and protections that have been negotiated. (This does not apply to Trust Fund which is PS Group's responsibility.)

Figure 15. Summary of PSA proposals from March 17 through April 10, 1987. 
anger, frustration and confusion. Some of the questions were:

1. Who set the April 30, 1987 deadline, and why was it moved up from September 30, 1987?

2. Does the Agreement and Plan of Merger between USAir Group, PS Group and PSA contain any optional deadline date after April 30 in case negotiations with the Teamsters or the ratification process are not completed by April 30?

3. How much money have the Teamsters demanded be placed in the Trust Fund?

These questions and their answers continued to be communicated to all PSA employees on a daily basis. Tension remained high and political activity was enormous.

In the midst of all this political behavior, surprisingly, on April 29, 1987, PSA USAir Merger Update announced that PSA and Teamsters Local 2707 had reached a merger agreement subject only to its ratification by the Teamster membership. Pressure from the employee groups that were represented by the Teamsters had stirred the local Teamster coalition into action that resulted in the agreement.

Three critical questions were asked on May 5, 1987 in the PSA USAir Merger Update with three meaningful answers. Employees of PSA wanted to know if they would be voting on a signed agreement or merely a proposal. It was clarified that a signed agreement was up for ratification. 
Employees wanted to know what would happen if one Teamster group did not ratify the agreement, and the answer given stated that there would be no merger with USAir if that occurred. Finally, employees of PSA wanted to know when the ratification process would occur, and they were told that May 17, 1987 was the deadline.

A summary of the PSA-Teamster Agreement was disseminated on May 7, 1987 (see Figure 16).

As the Teamsters voting took place, there continued to be tension in the air. Some employees believed that a majority of the Teamsters would vote against the agreement in the hopes that USAir would extend its deadine, thereby allowing the Teamsters to negotiate even a more favorable agreement.

On May 18, 1987, the day after voting, the PSA USAir Merger Update announced that PSA Teamster-represented employees ratified the contract modifications. The ratification of the agreed modifications to the collective bargaining agreement was the last major step needed to allow the acquisition of PSA by USAir Group to be consummated. The official and legal closing of the acquisition was expected to take place on May 29.

Chairman Paul Barkley said, "We are very pleased with the support shown by our employees and this acquisition of PSA by USAir Group is a tremendous opportunity for PSA and its employees to be a vital part of a major carrier in this industry." 


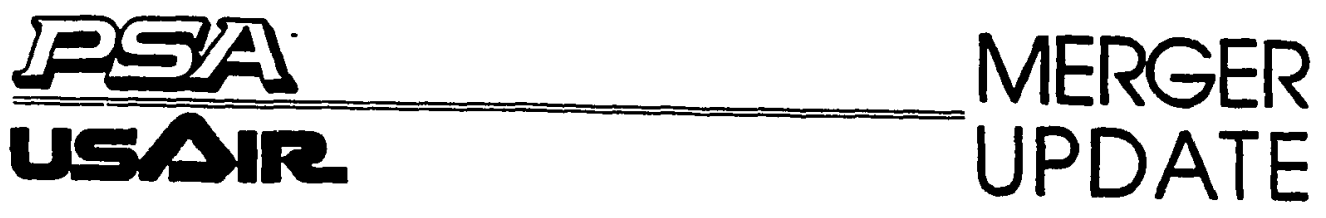

\author{
May 7, 1987 \\ Number 41 \\ SUMMARY OF PSA - TEAMSZER AGREEMENT
}

As is clear from the following summary, the Agreement is one of the best employee-protection packages ever provided in the airline industry.

- $\$ 36$ million Teamster-employee stock plan based on the $\$ 17$ per share sale price which USAir is willing to pay. Represents an $\$ 18 \mathrm{milli}$ ion increase in the value of the employees' stock plan over pre-USAir value, including payment for "disputed shares" and option shares.

Employees with one or more years of service at closing of the sale to USAir Group. Inc. Will share in the distribution from the PSP of the $\$ 36$ millition.

- Allegheny-Mohawk IPP's to Teamster-represented employees for PSA-USAir and USAir-Piedmont mergers.

- A "no wage rate reduction" guarantee.

- Pay and benefit protection for Teamster-represented employees engaged in seniority list integration activities.

- "No furlough" protection through December 31, 1987 , except in special circumstances.

- Base, domicile or station closure protection through December 31, 1987, except in special circumstances.

- Agreement not to merge operations of PSA and USAir before December 31,1987 in order to provide time for the integration of seniority lists.

- \$3.2 million Supplemental severance and outplacement Trust Fund to be administered by the Teansters and supervised by two independent trustees. Supplemental severance pay to be available to Teamster-represented PSA employees who do not accept USAir job offers requiring relocation to cities more than 200 miles from their work location. (Provides severance benefit not otherwise available under IPP's.)

- A written guarantee from USAir that the employee protection provisions and benefits contained in the agreement will be honored by USAir (this will be provided in the form of a signed adoption by USAir of those protection provisions).

Eigure 16. Summary of the PSA-Teamster Agreement. PSA USAir Merger Update, May 7, 1987. 
Chairman of the USAir Group Ed Colodny expressed his welcome to all PSA employees in a PSA USAir Merger Update released on May 20 (see Figure 17). In the short message, Colodny expressed his concern for the personal lives of employees and he introduced an ideal of pride to the new USAir employees.

On May 29, 1987, the sale of Pacific Southwest Airlines to USAir Group was completed. As a result of this transaction, PS Group's interest in PSA was converted into approximately $\$ 279$ million. The majority of these funds would be used to repay certain debts of the PS Group and its subsidiaries, taxes and expenses. The remainder would be added to the PS Group's working capital.

The PS Group would continue its remaining lines of business in energy sales and production, aircraft leasing, and related air transportation support services and would consider expansion of these areas as well as additional lines of business. The PS Group would remain listed on the New York Stock Exchange.

Figure 18 gives the letter from Chairman Paul Barkley to the past employees of PSA and current employees of USAir. This letter captured the essence of the transition of PSA to USAir, with all its benefits.

Due to the special interest groups and coalition building activity that prevailed during this slice of time, and due to the perceived need to communicate and intervene with employees about these activities, the 


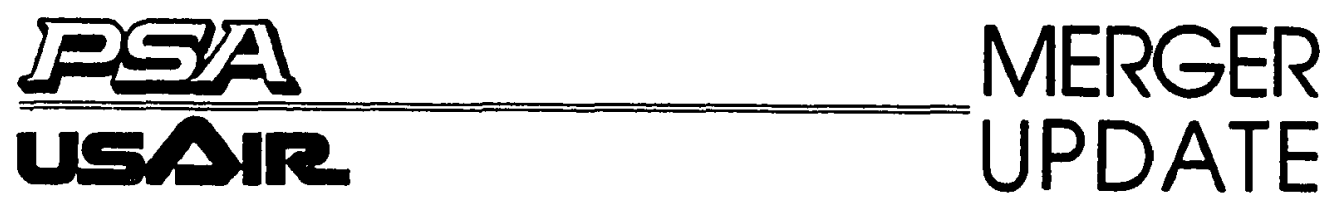

May 20, 1987

Number 43

TO AII PSA Employees:

I am extremely pleased with the news that the IBT ratification has been completed with a favorable vote.

To all of you at PSA, I extend a warm welcome. We are finally nearing completion of the acquisition process. Formal closing will occur on May 29, at which time shareholders will receive $\$ 17$ per share, and PSA will become a wholly-owned subsidiary of USAir Group.

In the months ahead I hope to be able to greet many of you personally. In the meantime, I re-affirm our commitment to a smooth transition with as little disruption as possible to your personal lives.

Later this year we will be joined by Piedmont and together we will form an airline able to compete more effectively with the giants of our industry. Challenges are not new to us. I am confident that together we will be able to shape an airline which will reflect our collective pride - and an airline good for our customers, shareholders, and employees.

Welcome to USAir Group!

Ed Colodny

Figure 17.. Letter from Ed Colodny to PSA employees welcoming them to USAir. PSA USAir Merger Update, May 20, 1987. 


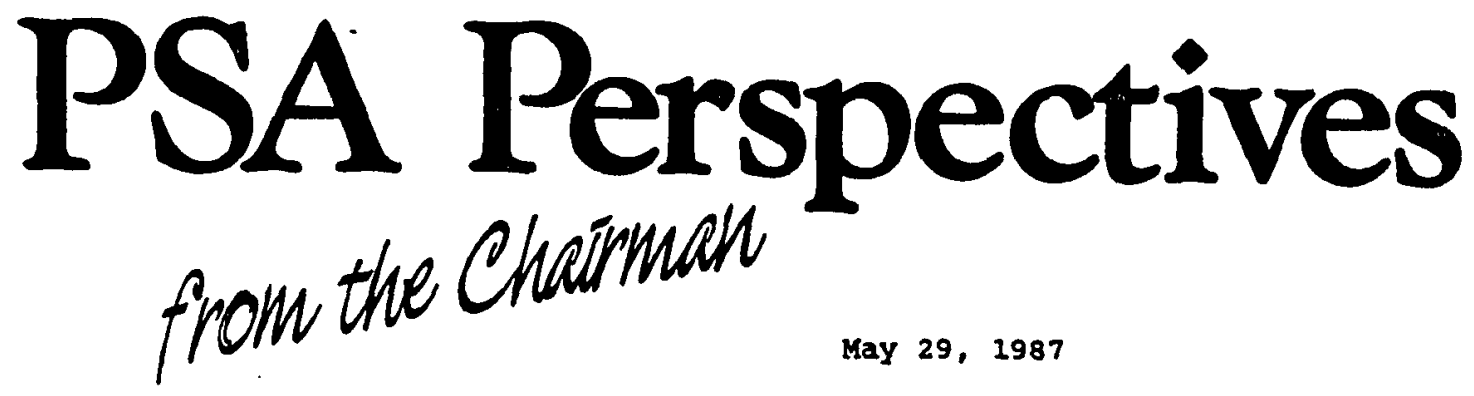

Dear Employees,

Today the acquisition of PSA by USAir Group was officially consummated and with that, PSA is now a wholly owned subsidiary of USAir Group. In spite of the many ups and downs we've all experienced in the last few months, our efforts are now being rewarded with the reality of new opportunities as part of a larger and highly profitable carrier.

When the board of directors considered the USAir Group offer last December, we felt that of all the merger possibilities, USAir had the most to offer the employees of PSA. Following are some of the many benefits that have been given to PSA employees:

- You are joining a profitable carrier with a history of integrity and falrness with its employees. If you have any doubt, ask a USAir employee.

- You have the most extensive labor protections over offered to employeas in an airline merger. USAir has oftered these extensive protections not because it had to, but because it chose to.

- The PSP, in which PSA employees share in the value of $\$ 65$ million - a substantial increase in the value of the employee stock plan over pre-USAir value. This includes payment for "disputed shares" and option shares. The PSP committees are now seeking the quickest way to terminate the Plan in order to distribute the funds to each participant as soon as possible.

- Agreement not to merge PSA with USAir before December 31, 1987 in order to allow ample time to integrate seniority lists in a "fair and equitable" manner.

- A \$3.2 militon Supplemental Severance and outplacement rrust Fund for Teamster-represented employees who choose not to accept jobs with USAIr that requires relocation outside the present PSA system.

As part of usAir, I congratulate each of you on a very promising future ahead.

sincerely,

Paul c. Barkley

Figure 18. Letter from PSA Chairman Paul Barkley to new USAir employees. May 29, 1987. 
internal mechanisms for articulating change have been seen from primarily a political and system-organic lens. The shape of this change evolving out of the special interests of a variety of different groups itself suggests a political model of change. Furthermore, the mere fact that the internal mechanisms for articulating the change were created, implemented and supported suggests a systems organic model of change.

\section{External Mechanisms for Articulating Change}

The data that were utilized to investigate the external mechanisms for articulating change were newspaper articles from a variety of different newspapers, predominantly from Southern California, but others from different cities around the United States. The way in which the press viewed the merger process of Pacific Southwest Airlines by USAir is quite significant in that it provides us with another lens through which we can view the change event. This external view of the change event was perceived to be an important one; so much so that PSA reproduced batches of newspaper articles each week and distributed them to all employees within the organization. The point was to help the employees of PSA see the change from as many views as possible so as to broaden their knowledge base and their thinking about the event which impacted them so much. If the employees encountered only the view of the change that was given in the internal mechanisms instituted by PSA (PSA NewS Update and PSA 
USAir Merger Update), they would have had a myopic or singular perspective of the merger.

A comprehensive collection of newspaper clippings were captured specifically from the time period of December 9, 1986 and May 29, 1987.

Geography plays a significant role in how the press sees a particular event. For instance, the press tended to view the merger from the point of view of PSA in articles that were extracted from California newspapers. Due to the fact that PSA was known as a California airline, this is not surprising.

Conversely, the press tended to view the merger from the point of view of USAir in articles that were extracted from eastern newspapers such as the Wall street Journal and USA Today. Since USAir is headquartered in Washington, D.C., and has its major operating hub in Pittsburgh, Pennsylvania, this too is not surprising.

Although a representative sample of clippings is used in this section of the study, the majority of articles came from the San Diego Union and Tribune, the Los Angeles Times, the Wall Street Journal and USA Today.

On the morning of December 8,1986 , in the hometown of Pacific Southwest Airlines, the front page of both newspapers featured the story that PSA and USAir had entered into a merger agreement. The language used was emotional and symbolic. Specific examples of how this highly emotionalized language was projected are worthy of 
a closer and deeper look.

The San Diego Tribune stated that "under the proposed agreement, USAir would become the surviving carrier, ending the 37 year existence of San Diego based PSA" (December 8, 1986, p. 1A).

On December 9, 1986, the San Diego Union said that "Pacific Southwest Airlines Inc. has agreed to be acquired by USAir Group Inc. of Arlington, Virginia for $\$ 400$ million in cash, a merger that would create the nation's sixth-largest airline but eventually deprive San Diego of its homegrown, locally based airline" (p. 1A).

From a personal-therapeutic lens, the San Diego Union (see Figure 19) wrote:

Assuming it would be just another day in her 19-year career with the airline, Lou Lehner reported for work in the accounting department at PSA headquarters on Harbor Drive at 7 a.m. yesterday. Barely inside the building, she spotted some mechanics that she knows. They said, 'Well, Lou, welcome to the wonderful world of USAir.' . . Lehner is one of about 2,500 PSA employees in San Diego who found out yesterday that the airlines management has agreed to a $\$ 400$ miliion merger with USAir.

The Los Angeles Times of December 9, 1986 began its description of the story by saying, "California air mass transit pioneer Pacific Southwest Airlines fell victim Monday to airline takeover mania agreeing to be bought for 


\section{PSA smile gets a little uncertain \\ USAir merger, cloudy future unsettle staff}

\section{By R.B. Breaner and Rod Rigqs Susf Writers}

Assuming it would be juat another day in ber 19-year career with the airline, Lou Lehner reported los work in the accounting depart. meat at PSA headquarters on Bir: bor Drive at $7 \mathrm{am}$ yesterday.

Barely inside the building, she spotted some mechanics that she known. . ? $\therefore$

"They said to me; Well, Lou, pelcome to the wonderful world of USAir;" said Lehner. "I said, "What'? It was a little shocking."' $\therefore$ tehoer is one of abqut 2,500 PSA empiloyees in Sin'Diego ino Jound out yesterday that the airline's munagemeat has agreed to a 8400 million merger with USAir, based in Washinglon, D.C.

News of the merger elicited a roller coaster of thoughts and emotions from PSA workers at the Harbor Drive headquarters and at Lindbergh Field.

Some. feared they might lose their jobs or be transferred to the East Coast Others were enthusias. tic about joining up with a finar. cially stable USAir. The most common response was uncertainty.

"There are a lot of questions" said PSA spokeswoman Margery Craig. "And trankly, there are a lot of questions that we don't bave abswers lor right now. There's a lot to be worked out."
$A$ bill collector for PSA, Lehner is not ready to retire. She is pro pared to move if that is noceciary to keep her job. "I feel like I have a lot to offer," ste said. "It won't be the same, but it's still the airline busisess."

Behind a ticket counter at Lind bergh Field, Larry Calpito was in rood spirits. Calpito, a PSA pas senger service agent for six yearn. explained: "Both airlines are very aireratt to service some of PSA's iscoaller martets, ba suid.

Coloday ruled ont the possibility that USAir would move its beadquasters from Arlington, $V_{2}$, to San Diego, sajing "it's a move we proba. bly can't afford."

The merger is sot likely to result in the relocation of PSA employees to the eart coast, but it could prompt some layols, said Colodoy.

- "There will ultimately be some dislocation" be seid "I thint it's bard to say there will be no job sur. pluse But with the base workload remainios stable, I see do reasoo why the place should be tureed up .side down"

The merter will oot result in wage "reductions far PSA or USAir employ. :een, sid Colodoy. Howerer, it is ur. : likely that the wages of PSA employ.

ees - Thich an 14 perceot to 30 perceat lower for variow job claseiCications thas those paid to USAir emplogee - . Fill incresse is the Desr future.

PSA explojes bave -eontrats witb the compeng that will expire at the ead of 1987.

"As loor as the two airlioes ari operation separatuly, the collective barpaining agreements of the two r. main is place" suid Colodor.

The question of whether the PSA name will remain will be "stedied very carefully" by USAir offleials, be said.

Figure 19. An example of the emotional language used by the San Diego press. San Diego Union, December 9, 1986, p. $1 \mathrm{~A}$. 
$\$ 400$ million by USAir" (p. 3A).

In another article the San Diego Union chose to

present the story as good news for PSA employees. The reporter wrote:

The merger is positioned for PSA employees because of USAir's financial strength and because PSA employees stand a good chance of having their wages elevated to the higher scales enjoyed by most USAir employees. PSA workers stand to make a windfall from the employee stock trust set up by the parent company. . - In essence, employees took 15 percent wage cuts in exchange for nearly 15 percent ownership stake in the airline.

On the front page of the business section of the December 9, 1986 issue of USA Today, the headlines read, "USAir Lands PSA Deal, $\$ 400$ Million Merger Would Help It Stay Number 8." The opening sentence was positioned from USAir's point of view: "USAir Group Inc. announced plans Monday to buy San Diego-based Pacific Southwest Airlines for $\$ 400$ million, joining the rush to buy west coast airlines" (p. 2D) .

Featured in the same issue, USA Today portrayed USAir's chairman and chief executive officer, Edwin Colodny, as a hero. The article, entitled "Agony over for USAir Chief," touted Colodny as the Harvard University Law School graduate, as outspoken and as a person who enjoys classical music and boating on Chesapeake Bay. As a 
hands-on manager, the reporter wrote, Colodny's airline since 1975 had been the most consistent profit performer of any airline (p. 1D).

The California press viewed the agreement announcement from PSA's point of view, as if PSA had been victimized, as if San Diego would now be deprived of its homegrown company, and as if the employees of PSA were, in a way, bought. The East Coast press viewed USAir as having made a strategic move to expand into the western United States and that USAir's leader was bright, human and successful.

The senior managers of PSA intentionally wanted all these views to be examined by the employees. The news clippings were disseminated via company mail to all employees to help broaden thinking. The avoidance of information deprivation was a deliberate tactic which is the reason why this change action was a part of the overall communication plan.

The following week, the San Diego Union featured an article that positioned USAir as the savior coming in to scoop up the ailing PSA. Language was used such as, "USAir aims to brighten Pacific Southwest Airlines' troubled smile," ". . . the proposed acquisition of debt ridden PSA by USAir Group Inc. for $\$ 400$ million will enhance the ability of PSA to improve its revenue base," "PSA's string of losses will not adversely affect USAir" and "USAir wrote the Bible on frequency of flights in its 
market, a feature for which PSA is known." The picture used in this article (see Figure 20) features Edwin Colodny as the central actor with PSA chairman Paul Barkley looking on (December 12, 1986, p. 3A).

Around the same time period, the cultural symbolic save-the-smile movement began. All of PSA's aircraft were well known for the smile that was painted on the nose of each aircraft. All through the years, PSA's advertising campaigns capitalized on this logo. Marketing slogans such as "Our smiles are not just painted on," "We've got to be tough to make you smile," and "Catch our smile" were all an integral part of the culture of PSA. Employees internalized the smile logo as a value of a positive, up, happy and enthusiastic personality of the organization. Over the years, PSA executives encouraged this value by allowing employees, particularly front line customer contact employees, to have fun. Like Mickey Mouse is to Disneyland, the smile of PSA became a primary cultural value within the organization. So strong was its manifestation to the public, the PSA smile became the trademark of how customers viewed the organization.

The press captured and sensationalized the smile of PSA as a major story. The question, of course, was would the PSA smile stay and be painted on all USAir airplanes too, or would it be painted over and die some culturally agonizing death? So the various reporters probed into every aspect of the life or death of the PSA smile. 


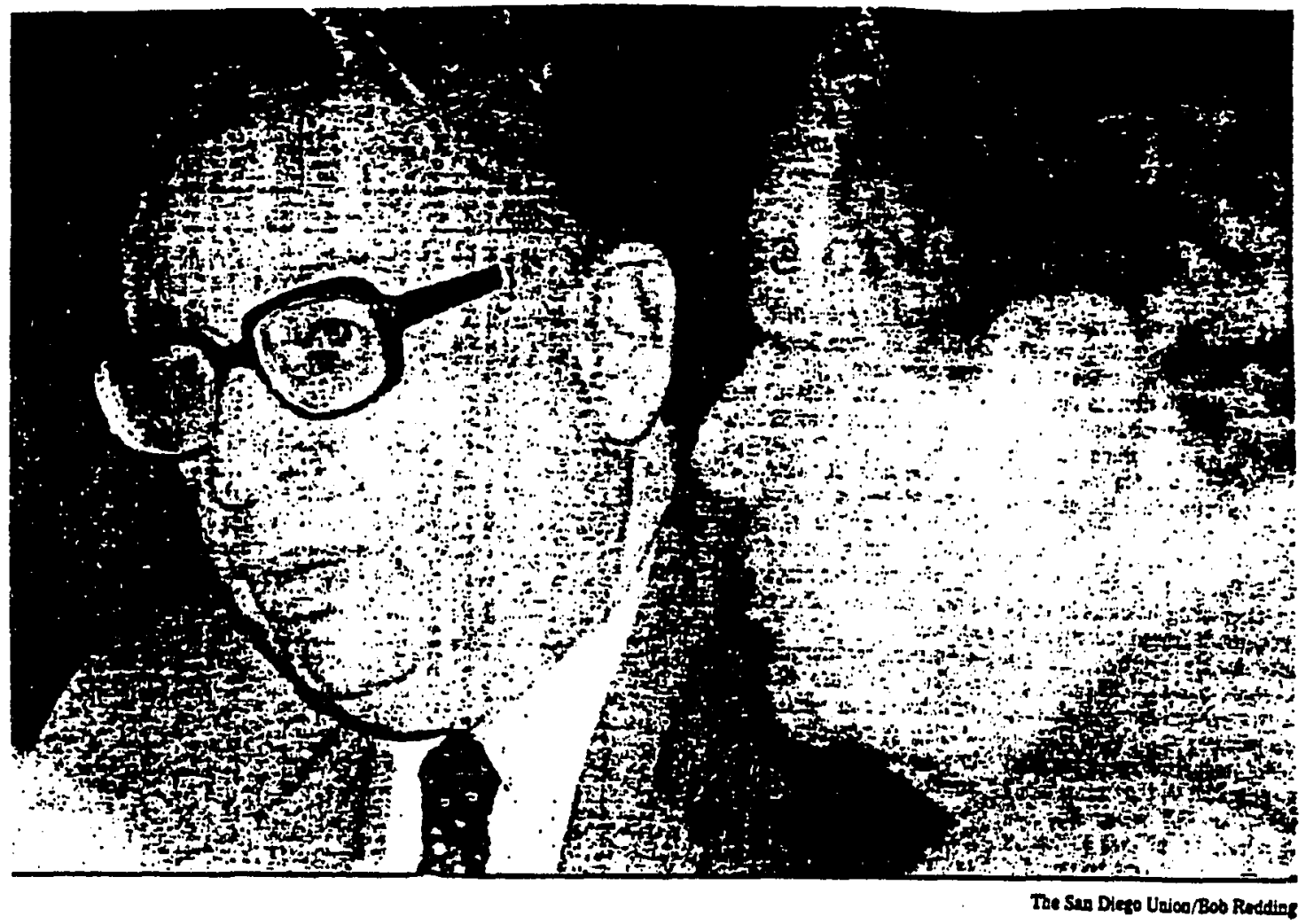

USAir chairman and-presidemt Edwin Colodiny, lett; speaks during a wide-ranging interview with reporters yeaterday at Packic Southweat Airlines headquarters while PSA chairman Paul Barkloy looks on.

\section{USAir head says merger to help PSA}

By S. Lymoe Walker, sinf wriem

USAir aims to brigbtea Pacific Southwest Airline's troubled smile by capitalizing on the San Diego-based airline's agTressive schedtr. ling tactics and its ser fleet of aircraft. the chairmas and president of USAir said yestar. day.

The proposed acquisition of debt-ridden PSA by USAir Group Inc. for $\$ 400$ milliga "will ea. hance the sbility of PSA to improve its revesue base," USAir chairman and president Edrin Colodny said during a wide-ranging interview with reporters in San Diezo.

Coloday said PSA's striag of losses will not adversely alfect USAir, which bas been the most consistently profitibly airlion for the past 10 yeare.

"If you're going to do aciuisitions, goo have to decide It's going to be profitable" be said. "The interest wo have aow is is making this one wort."

The stock martet appareatly is steptieal about USAir's abilits to continue to be profita. ble afler the merger. USAir's stock, which is traded on the Ner Yort Stock Exchaoge, has fallea 2H points since Moaday, whea it closed at 384h.

Stapdard \& Poor's yesterday placed USNir on a creditwatch and down raded its outstand ing debt "with nepative implieations"

"It is unclear if additioual revenoes recerat. ed by the combination will oftest added inter. est, labor and nop-eash espeneser," the debe rate ing service eaid.

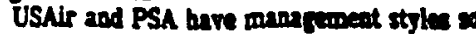
similur that there will be little noticeable change when the two airlines are merged, said Colodny. "Of all the mergers, 1 think this will be the least disurptive"

USAir "wrote the Bible on frequency" nf Nights in is martet, a feature for which PSA is known, Colodoy said.

"That bas made PSA successtur in California is that it has provided good, efficieat service" with ecoosomical aircrafl, be said "That's exactly what we do."

USAir, which usea Pittsburgh and Philadelphia as bubs plam to use PSA's aircralt and ronte netrort to expand its presence in the Testern United States, said Colodny.

\section{Figure 20: Article featuring an interview with USAir's}

Edwin Colodny. San Diego Union, December 12,1986, p. 3A. 
In the San Diego Tribune of December 11, 1986, an editorial appeared entitled, "Please Don't stop Smiling, PSA" (see Figure 21). The editor gave the opinion that California skies just would not be the same without those PSA smiles.

Even travel agents began speaking up. In an article from Travel Weekly of December 15, 1986, travel agents in PSA's home territory had one major concern about the takeover. Would PSA be allowed to maintain its own identity? The agents felt that the disappearance of the PSA name would be a major drawback because the people in the Southern California area would not recognize USAir to the same extent that they do PSA. One agent even said, "PSA and San Diego are synonymous. They have grown together over the years. USAir simply doesn't have the same recognition" (p. 12).

In another Travel Weekly article of December 15, 1986, the headline read, "USAir Says It May Retain PSA Name Under Merged Operations." USAir's Colodny was quoted as saying, "I would not foreclose the possibility that the PSA name will remain in some fashion, particularly in California" (p. 18). The remainder of this lengthy article reviewed USAir's plans for aircraft usage and merger hurdles yet to be overcome. Only one sentence of the article dealt with the caption, which suggests that the caption was used to captivate the readers.

On December 22, 1986 the Los Angeles Times featured 


\section{Please don't stop smiling, PSA}

IS IT OLR IMAGINATION or have the smiles on the Pacific Southwest Airlines fleet grown broader since USAir Group made its $\$ \$ 00$-million offer to purchase San Diego's hometown airline?

Although the proposed sale would mark the end of an era for PSA, the West Coast's first and most innovative no-frills, low-cost airline, it should benefit PSA employees and stockholders and ensure that the planes and crews continue flying.

PSA was founded in 1949 and began weekly service from San Diego to Burbank and Oakland with a leased DC-3. The painted smiles were years away, but the innovative approach of its founders was

evident immediately. Throughout its corporate history, PSA remained a trend-setter, most recently with the purchase of quieter, more fuel-efficient British Aerospace 146 aircraft.

USAir officials have said they initially will operate PSA as a separate airline and won't lay off any of its 5.000 employees. That's good news for San Diego and more than 2,000 PSA employees here. We hope USAir will permit PSA to retain its identity after the merger and maintain its San Diego head. quarters.

California skies just wouldn't be the same without those PSA smiles.

Figure 21: The cultural-symbolic power of the PSA smile. San Diego Tribune, December 11, 1986, p. 2E. 
an article called "USAir May Catch PSA's Smile and Keep It." The article revealed that PSA's smile painted airplanes had lots of flier recognition. Additionally, the creator of the smile was identified. The article stated, "Despite early indications that USAir would wipe the famous smiles off PSA's airliners to better match its own, more somberly painted fleet, USAir Chairman Edwin Colodny recently promised PSA employees that he will think long and hard before abandoning PSA's self-proclaimed 'smile that won the West'" (p. 6A).

The staff writer then stated, "Marketing experts suggest that colodny has reason to move cautiously before doing away with the smile that has been painted beneath the noses of PSA's planes since 1969. PSA maintains that its 'smileliners' were not the product of an ad agency - . but the creation of a mischievous maintenance man which a paint brush."

A marketing study had been conducted for PSA which concluded that only United Airlines' "Fly the friendly skies" slogan commanded more recognition among West coast travelers than PSA's "Catch our smile."

In the same article (see Figure 22) President Russell Ray advised Colodny to give serious thought to retaining the PSA name "because there's a hell of a lot of equity tied up in that name."

Even the Yakima Herald Republic newspaper ran an article called "Don't stop Smiling," suggesting that 


\section{USAir May Catch PSA's Smile and Keep It Ad and Painted Planes Have Lots of Flier Recognition, Survey Shows}

\section{By GREG JOHNSON. Times Staff Wriker}

SAN DIECO-When Jane Fonda scram. bles to get out of town fast in "The Morming After." a murder mystery movie that premieres on Christmas Day. she rushes to a Pacific Southwest Airlines tucket counter at Los Angeles International Airpor.

PSA - which in real lite carries about hall of the 8 million passengers who travel the "Calitornia corridor" between Los Angeles and San Francisco each year-evidently comes through in the clutch for Fonda.

Huwever. assumne CSAir Group's s400-mitlion bid for PSA is sucetes. ful-and if a future movie sequel requires a simularty quick trip back 10 LAX-Fonds could end up bookins a seat on a USAir flight.

Despite early indications that I'SAir would wipe the famous "smiles" off PSA's arliners to better match its own. more somberly painted fleet. CSAur Chairman Edwin Coloday recently promised PSA employen that he will think "lon ad hard" before abandoning PSA's sell-proclaimed "smile that won th. verr"

Marketing experts sugrest that Colodny has reason to move cautious. ly before doing away with the smule that has been panted beneath the noses of PSA's planes since 190. PSA maintaing that its "smulelines" wers the product of an ad ageney - not as legend has it. the creation of a michimen maintenance man with a puint brunh.

A recent marketing study contreted to PSA suzgested that only United Air Linea' "Fly the Frendly Skies" slogen commund more recogmition amons West Cout crev. elers than PSA's "Cuch Our Smule."

In that study. 35\% of Wea Coan respondents correctly identified the PSA slogan. In tos Anjoder $72 \%$ of thow responding made the asociation.

United's "Frendly Skies" was correctly identufied by $33 \%$ of West Carst respondents and by $81 \%$ of Angelenoe.

That kind of consumer awarenes: contrasted with Alaska Air Lined' "Fly With the Happy Face" slogan, which was cor. reculy identified by only $5 \%$ of Weat Const

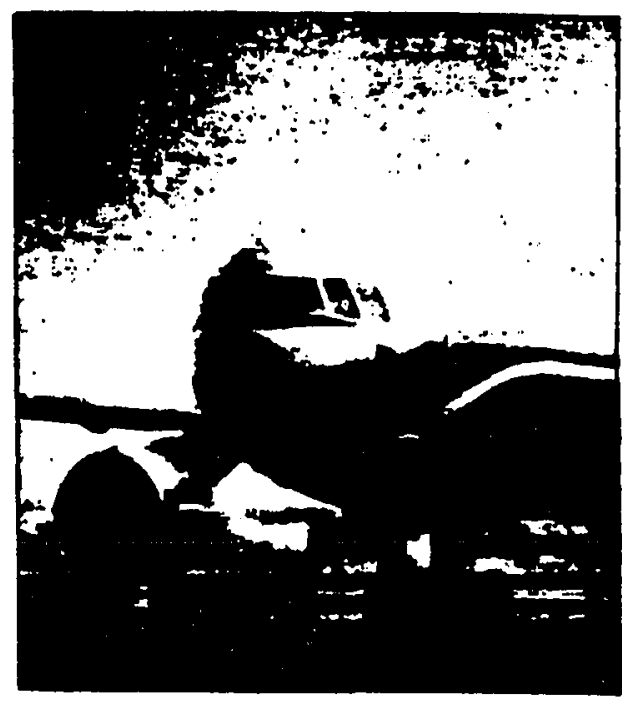

repondents in the PSA-sponeored survey. And. in a finding that brougthe mitles io PSA fecen 33\% of the mepondents thourthe that the "happy lece" belonerd lo PSA

USAir, which has not conducted a resent marketing survey in the Weet is "ex. tremely well known" in the exterm United Sucke, scecoding wo spokeamen David $\mathrm{g}$. Shipley. He actenowledend that name ros. osnition "drops ofr" in the Were, where
USAir has relatively few flights. C'SAIr wants to "enhance that awareness." Sht. pley said.

The airline successfully played the name-change game in 1974. It dropped the longtime desigmation Allegheny Airines and bacame USAir. a name chosen because it seemed more likely to be perceived as that of a "bis aurline." The new name atso had the advantage of distancing the carrer from the unwanted "Ago. ny Airtines" nickname that might stull be burned in the minds of Easterners who since heve migrated to Califor. nill, one airline marketing expert said. Marketing sources agree that the relatively unknown LSAIf might cap. Italize on PSA's image as a well-es cablished. low-cont. high-lrequanc. nier that bousts a spanking new fleet.

PSA Preaident Russell Ray believes Colodny should give serious thought to retuining the PSA name "because thers's a hell of a lor of equity tied up in that name."

"I'd so very slowly if I ware running the show at USAir." sald Arizon State Universtly marketing Prof. Jefl Bracker. who suggested that it would be "a miscake to auto. matieally change the name."

But Jim Sowers. a University of Hourcon marketing prolessor who studie airtine mergers. said. "The keye are price and service and. Il USAir can provide them. then there's no problem' with eliminatung the PSA name. slogan and strile.

"Taking their tume is the best thing they could do nght now." one marketing expert surgated "You don't want to push 100 hard on the travel asenes or the public. It takes a long time to get the right lecting mith a new name."

\section{Figure 22. Will USAir keep PSA's identity? Los Angeles}

Times, December 22, 1986, p. 6A. 
Yakima Valley skies would not be the same without PSA smiles (December 23, 1986, p. 7B).

For the remainder of December 1986, news media covered the merger agreement story and more on the smile controversy.

In late December, the San Diego Tribune broke the story about the potential conflict between PSA and the Teamsters' Local 2707 (December 28, 1986, p. 2A). The reporter correctly revealed that the Teamsters had filed grievances with Pacific Southwest Airlines, protesting the airline's intended merger with USAir. The Teamsters had asked, it was reported, for the grievances to be submitted to arbitration. PSA had informed the Teamsters that the grievances were not subject to arbitration.

The news coverage in January of 1987 regarding the merger of PSA and USAir focused on the pilots union's agreement to the merger provisions, the Department of Transportation's approval to merge, and the Teamsters' opposition to the merger. But the saga of the disposition of the PSA smile, still dominated the media coverage.

Both the San Diego Union and the Los Angeles Times of January 23, 1987 announced that PSA and the Air Iine Pilots Association had reached an agreement to modify the contract language that could have blocked the proposed merger of the San Diego based carrier and USAir. ALPA, which represented 700 PSÄ pilots, had received assurances from both airlines that key provisions of the contract, 
such as the seniority list, wage scale and severance pay, would be maintained after the merger. ALPA, in turn, agreed to waive its right to initiate an employee buyout of the airline.

Thus, a major success had been realized. The pilots' agreement represented the first consensus in favor the merger. So many more approvals were to come, but PSA and USAir executives thought that the credible pilot group might create a domino effect which would influence other groups to accept the proposed merger. More details on the pilots' agreement are in Figure 23.

In late January, the United States Department of Transportation gave tentative approval to USAir Group's $\$ 400$ million bid for PSA and suggested that the proposed merger would not reduce competition on the three routes where the two airlines compete. The Justice Department, which makes recommendations but does not have final power of approval on such mergers, concluded that the USAir-PSA deal would not lessen airline competition. The three routes that both PSA and USAir served were Los Angeles to and from Phoenix, San Francisco and San Diego. The Wall Street Journal carried an article on the approval (see Figure 24) as did other major newspapers.

On the political issue of the Teamsters, the Los Angeles Times of January 25, 1987 reported that there could be some "mid-merger turbulence" as PSA employees who belong to the Teamsters union found themselves in 


\section{PSA pilots OK merger provisions}

\section{By S. Lyose Dilker}

Preilie Southrian Airlion ad the Air Live Pllous Asectiatioe yenterday anooseced thes bave rencend an a preverent to modily contract has cuace that conld have blocted the propond merror of the Sas Dieno burd sirlion and USAir.

ALPA vilich repromete 700 PSA pilote recired amoraces troen both airlion that key provisioes of the contract - such as the seniontity lint ware sella ad sererased pay would be muiatained after the wats

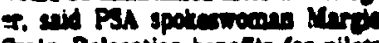
Crile Relocetion beodats for pilod ratind to wove so a mold of the worter were aleo a pare of the aprement sta side.

ALPA is term and to weive it ritat to iaithen as explojes bojout of the sirtine. The mice alo relin. quistred its right to apply the PSA cootract to rorting condition as

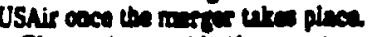

The uaios said the contrace

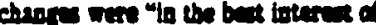

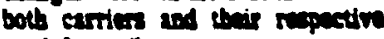
work forcen"

"The combined foren of a stroes

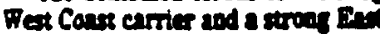
Cont carrier will provide a terculc ble comperiter is the sinter inder tsy." ALPA spotemenen Pon Pout

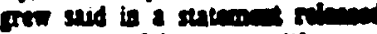
renterduy. "Job oppostin wh

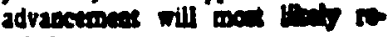
sult"
AlPA if the tist a for micen represcetlas PSA explojese to 2 ow to costrect modifiention the USAir said were a aceners proce sor to the weres.

USAir Grow loe to Decentur a

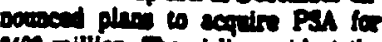

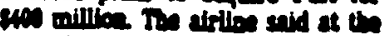

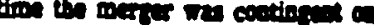
the modifention of Pan's hater or tricte

PSA Is atteropth to andine

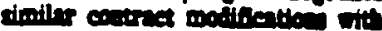

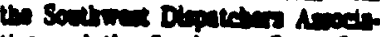

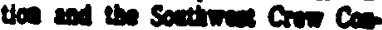

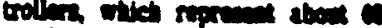

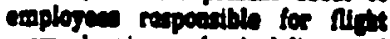

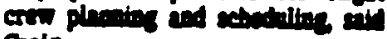
Crive

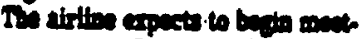

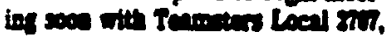

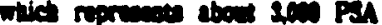

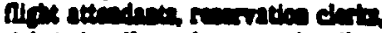

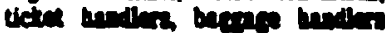

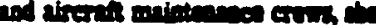
vil.

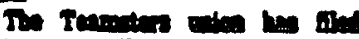

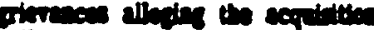

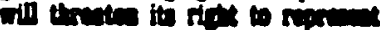

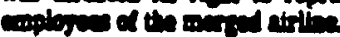

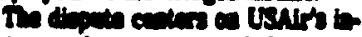

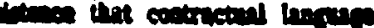

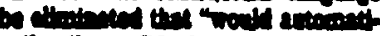

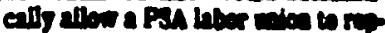

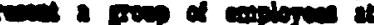

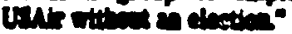

Oals a randtol" of USNir's em. plojere priminily the round ser. vies ane in the airtion's Piltesturgh

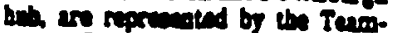
sters. Reurvation clerke ticket

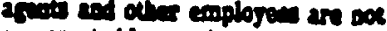

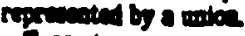

Tenmens reprementive is Sa

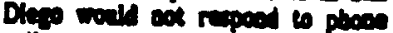

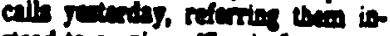

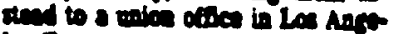
in Repratative is the las Anso

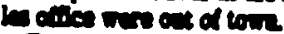

Bowever, Gll Oater, beriaces apes tor Leel 870 , sid in an entio

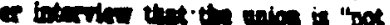
rotes to be aropeded bs a 'quole' soced the

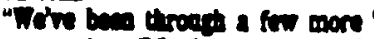
merpe tha PSA" be said "so I thin's we can poe a cood dal whes we 20 it"

In a relued matter. PSA and its

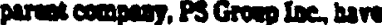

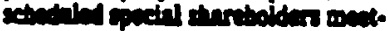
ing on Mintel 17 to condider UShir's meris presenel

The compenis sope to have all

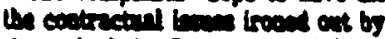

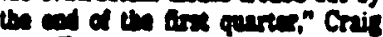
cid Bown, shrebelders as on bard trow rotis on the watter

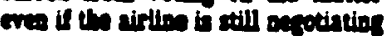
with the wisen

\section{Figure 23. Pilots Association reaches agreement to accept}

the merger. San Diego Union, January 23, 1987, p. 6A. 


\section{USAir Plan to Buy PSA Gets Approval From Regulators}

By Lackele DifGixisy

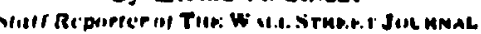

WASHINGTON - The Trunsportation

Department tentatucely ipproved USAir Group Inc. 's proposed itwo million acquisition nf Paritic Southwest Airlines. saying that competition wouldn't be reduced.

The cnmbination of Wishington-based I'SAIr Gimup and Sin Diezo-bused PSA. a timl of PS Group Inc., would create the seventh-largest domestic carner. with a t.I:; market share in revenue-pascenger miles. the department said.

In giving its tentutive go-ahead. the irinspurtutton agency sard that LSAir and PS.I nperite largely in different renons of the country. L'S.tir's principal hub is Pites. hurgh. ind of the 43 durports the arline serves. unly about a dozen are west of st. Linuss. PS. serves 29 uirports. mostly on the liest Conast.

The illrines do compete on three non. stnp routes: Los Angeles. Phoenix: Los An. geles.San Francisco and Los angeles.San Diezo. But because other carriers ain serve these markets and because CSAir is is "relatively minor participant" alons these routes. the merget wouldn't subatar. tally decrease competition. the department argued.

The department tumed dow the air. lines' request to bypass the customary ac. quisition-review procedures. saying that a "transaction of this sigmificance" dictated udhering to the normal rules. It also said that interested parties should tile com. ments or objections within t5 days.

The acquisition represents the third such transaction in recent montus of a West coase retiond airtine by a larker carrier. AirCal. PSA's mats competter on the Los angeles-San francisco route. was acquired by American Airlines. a unit of AMR Corp., while Westem Airlines was bought by Delta .ivr Lines.

Department ofticials also declded against imposing certain conditions in the CSAir.PSA acquisition desimed to protect employers who may be hurt by the merger.

A spokesmon for PS Growp and the company was "delighices" wh the asency's tentauve approva: USAr offclats conden't be recind.

Figure 24. Government regulators approve merger plan. Wall Street Journal, January 29, 1987, p. 2A. 
the powerful position of being able to stall or possibly block the proposed acquisition. The Teamsters argued that PSA had contracted with the unions to do certain things, and PSA contracted with USAir to change those things. The turbulence initiated by the Teamsters (detailed in Figure 25) was viewed by PSA senior managers as a stall tactic. It was a coalition against the proposed agreement parameters and they were anxious the press coverage added greater visibility to the opposition.

of greater magnitude than the first three issues (pilots' agreement, Department of Transportation agreement and Teamsters turbulence) the smile issue continued to be the dominating news story. The January 25, 1987 San Francisco Examiner headlined proclaimed "PSA's Smile Draws a Suitor." The writer opined: "We look forward to a new era in which another upstart airline such as PSA can take to the air. Meanwhile, we're not smiling" (p. 3B).

The Grass Valley Union and the Oxnard Press Courier each ran articles titled "Keep on Smiling PSA" and "Smiling Skies," respectively. Each article expressed the view that California and the PSA smile go together (January 25,1987 ) .

The San Diego Tribune printed the picture and caption given in Figure 26 as part of an article on the PSA smile. A marketing study suggested that USAir which was in the west should capitalize on PSA's image as a well-established, low cost, high frequency flier that 
PSAUSAir Merger Pivots on Teamsters

\section{BY GREG JOKWNSON. Times Staff Writes}

SAN DIDCO-There could be some mid-merger turbulence in USAir Group's $\$ 400$-million bid for Pacific Southwest Airlines, as PSA employees who belong to the Teamsurs union find thesnselves in the powerful position of being able to stall or posstbly block the pro. posed acquidition.

Despite Int week's quick approval of contract modifleations by oft PSA pilote, the San Refin Dieso-based ajrline has yet to obuin changes in the Teamsters' contracts that are neeesary before USAir can complete its pending acquitition of $\mathrm{PSA}$.

The Teamsers, who have not berun barcainine with PSA, are likely to seets a court order that would force PSA ineo binding arbitration over the contract modifieations being demanded by USAir as part of its proposed acquisition. according to Marvin L. Griswold secretary-treasurer of Teamster Local 270 .

Ftlot Were Pleased

That is in contrast with the attitude of the Nir Line Pilots Assn.'s 600 members at BSA. Thay were "extremely pleased" with the job security guranies nepotiated in retum for contract modifications. demanded by PSA and USAir. according to ALPA spokesman. Pete Petusrew.

PSA' 3,200 Teammen an "op." posing anythin that takes awn the protection we've nezoltated on behall of employeen." Griswold said during a telephone interview. The Teamites bive separate contracts with PSA cayering mainte. nance workers. ntht attendants. reservations agents and operations Plovio seo PSA, Pacte 15

\section{PSA: Teamisters Hold Key}

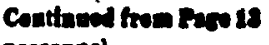
personnel.

PSA and ALPA resched a quick agteement becaus ALPA's contraet "didn't have the very, very involved (merter and coquirition) lariuge that we have." Gritrold satif "If they had the protective laogurg. they might be tring another look"

PSA, which eartier this month gave the union " 32 paces of pro. posed (contract) modifications. . is renesing on a commitment thoy made to employees th exchange $f 0 r$ concessions," Ginwold wid According to a recent Teamster newsietter, PSA proposes, amons other things, to altor sentority benefits and the so-culled laber protective provitions

Unlike ALPA, the Teamiters union holds contrects the gurne tee financial protection to its medn. bers if they las thed job beceure of a meryer. The contruets would lore USAir to ineorpotalle the protective providions into contruct covering employece represented by the Teamiters after the airlin: are merced.

And, the contrets would allow the union to continue representin. its PSA membar until after senior. ity isves renerated by the merze. with USAir are corted out.

PSA officinls would not commen: on the negotiatton, but one airlin source suid PSA believes that majar sections of the Teamiars' contrzets "are dimply uneniorcenble" beciuse they rim counter to exab. bished labor int.

- In Departuent of Transpertition filinge, USAir hes indiented that it thll frant the protentive provitions ip formet PSA employes, but the them into its liber contracts, Gris. vold anid.

- The Teamstar won the unurual rierce and secuidition contrict cluve trom PBA in 1984 es part of packere thut cut wowe and benefite by $15 \%$, eased work rules and inve stoel to PSA cmployea.

- Accordina to Griswold PSA Çhirman Paul Barides once discribed the Teamster protective drovition as "the finet protective ban ure in the indures."

- I tis contrege prove to be binding, the Teamtero "hold the key to this merse." atd Cavries Bohmus, a in:me: ien is it:
Comell University School of In. dutrinl Relations who arbitrates arline and railrond labor disputes.

USAir hes charged PSA with negotinting the changes but "the contracts reem to be USAir's prob. lem." Rehmus suid. "If they don't like the contruct, they don't have to acquire PSA"

"I think (USAir Chairman Ed. win) Colodny holds the key to this merger," Griswold suid. "We do not have the ability to . . make it Ily or top it."

The legelity of the merger and acquisition clause "is up in the air" accorting to one airline industry cource tamiliar with the contracts. "It's not a cut-and-dried issue [because) there's case law on both sides of the fence."

The Tenmers are arguing that "PSA he contrected with the union and employees 10 do certain thing and they've contracted with USAir to change thove things." according to the attornes who wrote ise Tesmetar contricts. "If [USAir want] the mercer to 80 though then this dispute has 10 be resolved"

PSA' Teamsters members "could find themselves on the bot. com of another carrier's sentonty list in a subsequent merger" if the langunge is dropoed Griswold sald. "Or, even worse. (employees) could find themsolves without jobs and without any . . . protective providone"

According to airline sources. PSA he maintained that its contrectual obligation to provide the protective provistions to Teamster employew would not be binding in the event that the merzed PSA/USAir eartier were subsequently acquired by still another airline.

Figure 25. Mid-merger turbulence initiated by Teamsters.

Los Angeles Times, January 28, 1987, p. 12A. 


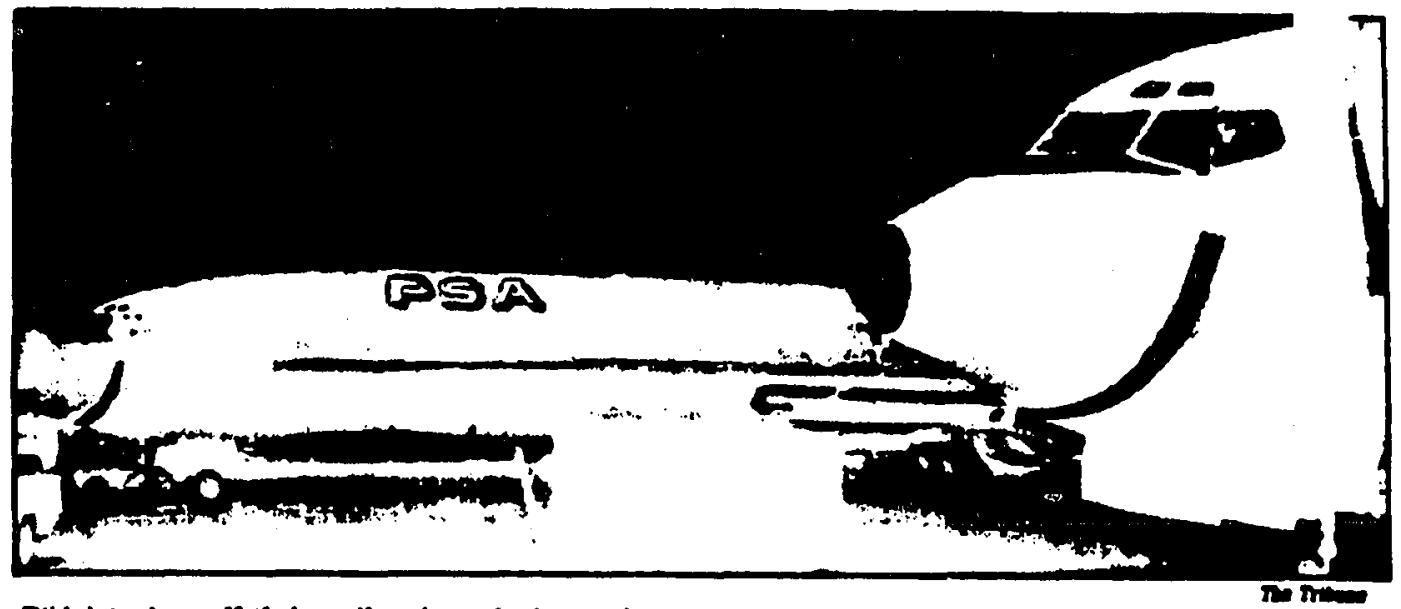

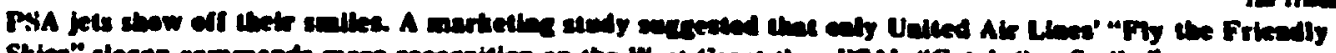

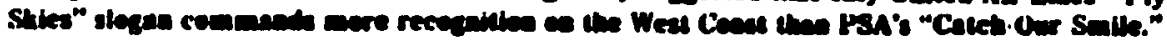

Figure 26. The PSA smile. San Diego Tribune, January 29, 1987 , p. $6 B$. 
boosted a brand new fleet. Now that was something to smile about.

The importance of the organizational symbolism of the PSA smile continued both in the press and among PSA employees. This aspect of the PSA organization, that its members used to reveal the values that were inherent in the organization, maximized the desire of the press to write about it. The symbol of the smile at PSA was not only an object but an act, an event, a quality that served as a vehicle to convey meaning.

In February of 1987, the thrust of the news focused around two primary issues. The first was the continued resistance on the part of the Teamsters coalition to reach an agreement regarding the contract provisions for the proposed merger. The second was the fact that another group, the PSA dispatchers, had reached agreement on contract changes. By far, the former issue was paramount.

Figure 25 shows a significant release from the press as it relates to conflict, interest groups, the powerful and the powerless, coalition building and more. The response was a letter from a PSA employee published in the San Diego Union on March 5, 1987.

I am a PSA employee of $8 \frac{1}{2}$ years in the reservations group who would like to respond to your article headlined, "PSA/USAir merger pivots on Teamsters." Your wording needs a correction. We employees who are Teamsters are not in a powerful position of being 
able to stall or block the proposed acquisition. The leaders of the union may be in a powerful position, but we, the dues paying members who they are supposed to represent feel that we are powerless. We are frustrated that our so-called representatives may ignore our wishes and prevent the acquisition. It is apparent that the Teamsters have not read all the letters sent to them asking that they not oppose the merger and the contractual language changes requested by USAir. Angry sentiment toward the Teamsters is pervasive at work because we fear they could be damaging our future. Many, if not most of us, have signed petitions asking that the Teamsters not interfere. Our voices are not being heard (p. 2A). Pressure opposing the Teamsters' position was building. A headline in the Los Angeles Times of February 3, 1987 stated "PSA Attendants Urge Teamsters to Agree to Contract Changes." A large percentage of PSA's near one thousand flight attendants had signed petitions demanding that the Teamsters nion agree to the labor contract provisions that had been requested by PSA and USAir (Figure 27). The petitions had drawn support from about $80 \%$ of PSA's flight attendants and about $50 \%$ of PSA's station agents. The Teamsters responded by telling the Los Angeles Times that the petitions were based on "erroneous" assumptions about UISAir's proposed acquisition of PSA (p. 12A). 


\section{PSA Attendants Urge Teamsters}

\section{to Agree to Contract Changes}

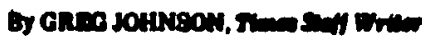

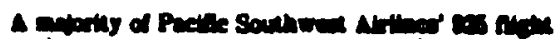

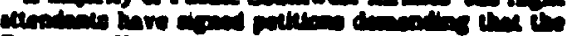

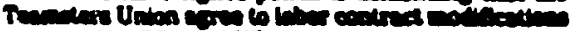
ramed by fas exusur.

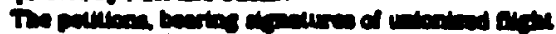

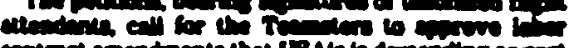

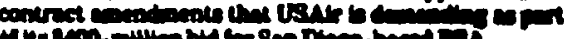

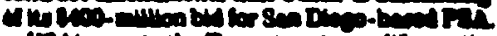

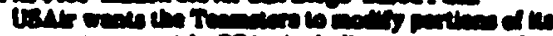

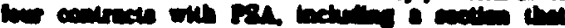

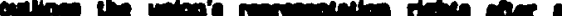

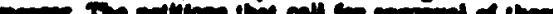

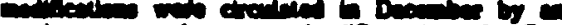

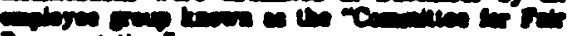

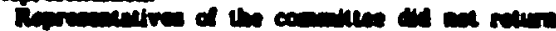

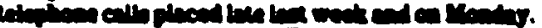

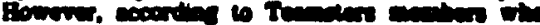

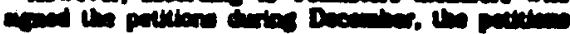

Committee members 'are acting on blind faith (in management promises] and nothing more.... The whole ides of giving up hard-fought language for nothing in return is appalling.'

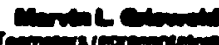

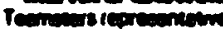

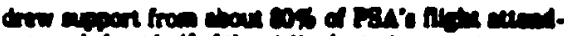

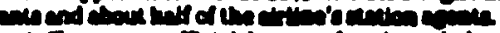

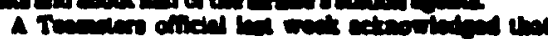

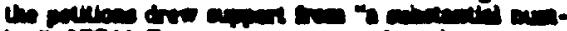

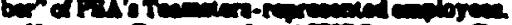

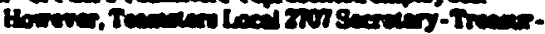

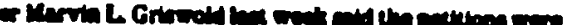

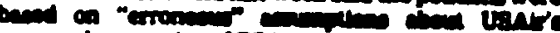

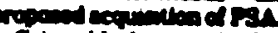

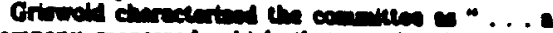

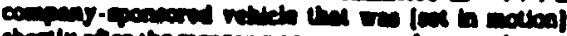

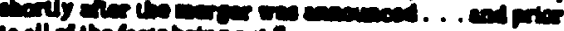

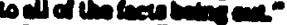

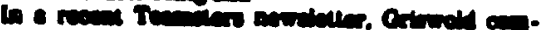

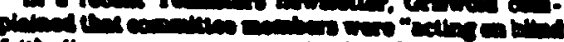

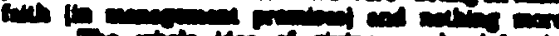

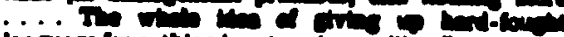

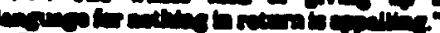

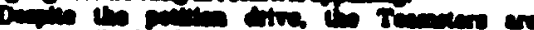

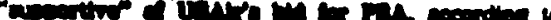

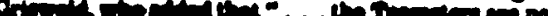

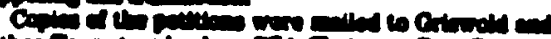

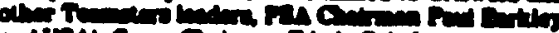

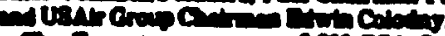

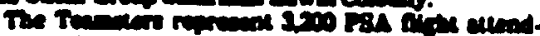

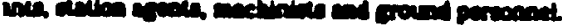

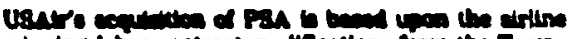

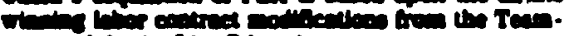

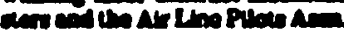

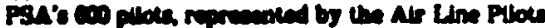

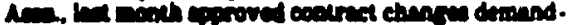

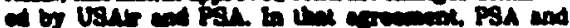

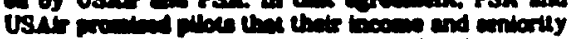

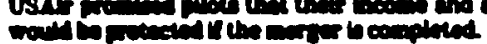

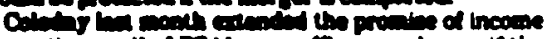

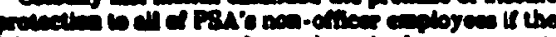

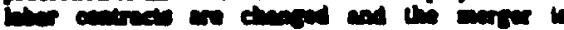
cionimat.

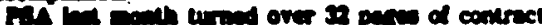

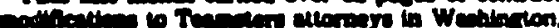

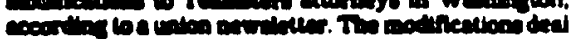

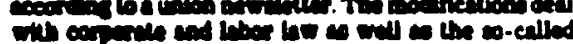

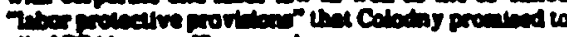

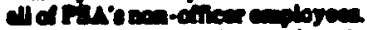

Cy

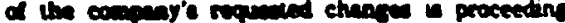

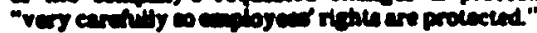

Figure 27. Teamster opposition builds. Los Angeles Times, February 3, 1987, p. 12A. 
clearly, a division between groups had resulted. Employees were shocked and frustrated. As a result of that frustration, they initiated on their own several action groups which were designed to publicly pronounce their collective views against the opinions of the Teamsters.

The Teamsters took action too. That same week the union sued PSA in an attempt to force arbitration. They asked the federal court in San Francisco to force PSA to arbitrate the dispute over contract language. PSA contended that the questions raised by the Teamsters were representational issues, not contractual issues. The essence of the Teamsters' view was that PSA should be bound to carry out the provisions of the labor contract that USAir had previously described as unacceptable if USAir was to conclude its bid for buying PSA.

The Teamsters felt that their position had power because of the similar court challenge generated by a contract dispute with Western Airlines which had been acquired by Delta Airlines. That suit, too, had yet to be settled.

The San Diego Tribune summarized this struggle for power and influence in its article entitled "Teamsters Suit Could Peril PSA Merger, Company Says" (see Figure 28).

The members of the Southwest Dispatchers Association had only twelve members; however, their agreement to 


\section{Teamsters suit could peril PSA merger, company says}

By Carl Larsen

Trbus Aniorese Pinecial Editor

A suit filed by the Termsters secting to force Pacific Southreat Airline into biodiag arbitration with the union could jeopardise the carrier's plam to merge with USAir Group Ioe. a PSA spotrermens said yetandas.

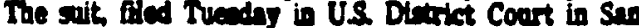
Franedece, cootend that PSA is violation terme of labor a greemente with four Tenmrer barchining units the cover procedure to be followed if PSA anders with another carriex.

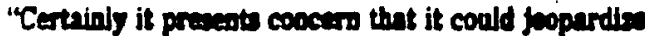

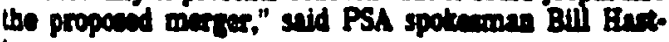
in.

Ins action wes flled by Temeter Loed 770 , which

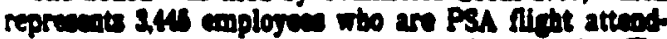

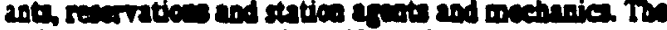

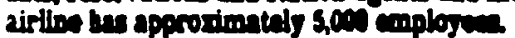

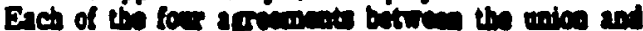

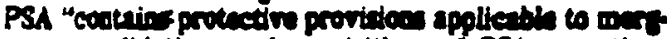

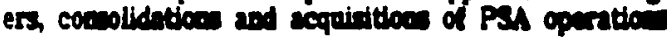

and thow of another carrer," the suit said.

At isenes is the status of the preseat Teamater bargain ing units once the merter is carried out For the merger to proceed USAlr has stated that eristiog coatract lasguage civios Tenmetes the right to represeatation after a merger mus be chinged.

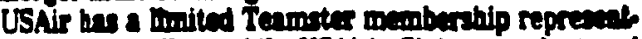

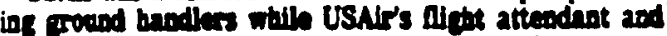

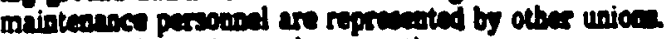

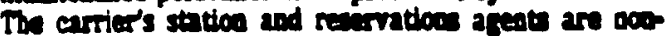
unio enplosw

USAir spoteren Daw Stiples said the dirlines would have oo commets of the couplaing which onme USAir as a defendne

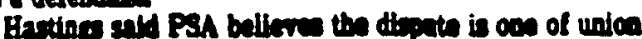
represention ond the the domin of the Nationd Mre diation Boerd "and oot sobjex to artitration" under ex.

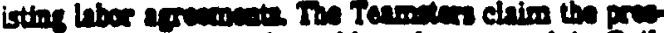

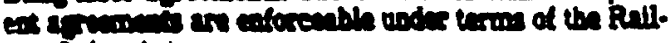
was tabor sat
Marvin L Griswold secretary. tressurn of the Teamotas locil vas unverilable for coonmon

Eristing couterest langres, the union sape in the seith providen the

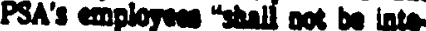
grated with explosen of the other carrice involved in the mers ... without acherent of the Team sters" of throen artitration.

The Tenmente bave acted th court to fores the isme into binding artituritoas

USAr has enid that for the morn to procent existing coaterces in. Juap mos be wodtind

The airlin lest whes and to would

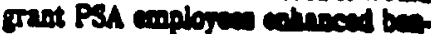
efit to an perooned wto was adversily afficted by the weres through job lajoth of foresd reloce. tion.

Bestinge satd the airline was surpribed by the sit sines it bas 90 to sit dowe with the unios to discrin the onery is detail

"Tus teametes have told coops. of otiodals the thes bava't ane with us beaves it's a comples ismo and thestre studyta the chanes.

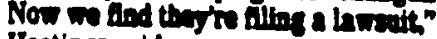
Instions sald

Howne, a soures said the enrite. and the uniog were sctioduled to ment today to discer terme of the matur.

Redisanes by the Teamenters to se.

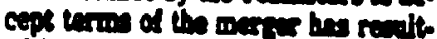
of in scose members of the unice at PSA to circulate petitioen soriting the

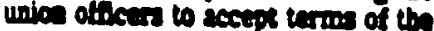
HAN millibe boyout of PSA bs USAir.

\footnotetext{
Figure 28. Teamsters sue PSA in U.S. District Court. San Diego Tribune, February 6, 1987, p. 10A.
} 
contract changes was critical. In mid February, the press reported in many newspapers that this union had reached agreement to modify merger and acquisition language. The union had received assurances from both airlines that key provisions of the contract, such as integration of the seniority Iist, maintaining the wage scale and severance pay, would be maintained after the merger. The union, in turn, had agreed to waive its right to represent PSA employees once the merger of operations was completed.

The Southwest Dispatchers Association was the second of four major unions representing PSA employees to agree to contract modifications which USAir had said were a necessary precuxsor to the merger.

The four dominant news issues in the month of March, 1987 were TWA's play for USAir and USAir's bid for Piedmont, the PSA Crew Controllers contract agreement, the shareholders approval of the merger and more unrest between the Teamsters union and its membership.

In the middle of an already confusing and anxious time, the Wall Street Journal stated on March 5 that TWA had proposed to buy USAir for $\$ 52.00$ a share (see Figure 29). This move was highly political in that it was a ploy to have USAir turn around and buy TWA and as a result drop its bids for both Pacific Southwest Airlines and Piedmont. This change event was filled with complexity and it caused a significant reaction in the mega structure of the entire airline industry. 


\section{TWA Proposes To Buy USAir For $\$ 52$ a Share}

\author{
Carrier Led by Icahn Is Said \\ To Boost Stake to 9.9\%; \\ Analysts Call Bid a Ploy
}

By Tou Agixs and Leture P. Cohey staf/ Reporters of TuE WaLl. Staker Jicinnal NEW YORK - Trans World Airlines. as. serting that it had become USAir Group Inc.'s largest single holder. made a sur. prise proposal wo buy the rest of the airitine or $\$ 52$ a share.

USAir had no immediate response. Some Wall Stret sourees viewed the pro posal stepucally. seeing in it a ploy to preseure USAir into buying TWA.

The 552-2-share prtee values all of USAir at more than $\$ 1.6$ billion, based on the 31.7 million shares that would be out standing after conversion of cerratn securt ties.

TWA's proposal. and its disclooure that it had acquired a lares block of USAi stock. caught Wall strent speculawors of guard. As word of the proposal spread.

\section{The Two Airlines}

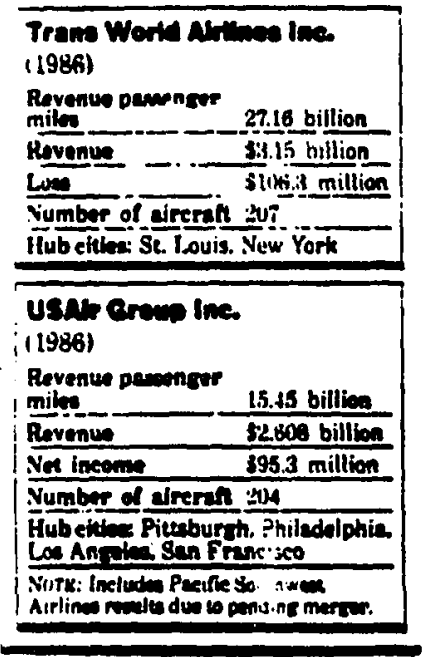

\section{Figure 29. TWA proposed to buy USAir. Wall street}

they quickly sent USAIr's share price soar. ing on the Vew York Stock Exchange. The shares closed in compostte trading at 49.125. up 55.375 .

TWA Chamman Cant C. Icahn. in a let ter to USAir, raised the possibility of a three-way merger of TWA. USAir and Pledmont aviation inc., which USAir he made a bid to acquire.

Pledmont Aviawon's board learned of TWA's action as directors were meeting to consider competing takeover olfers from Nortolk Southern Corp. and USAir. Pledmont's boand had been expected to relue. tantly accept USAir's propoenl. but lnstead directors recessed the meetine without ac. tion and without comment on yesterday's activity.l

However this latest development plays itself out. it probably will represent another major milestone in this industry's consolidation. "Il it becomes that three way combination ITWA. USATr and Fied. monts, you're down to seven major cap. rters," said te Homard execunve viet president of Airtine Economics lne. Washingtoa avtation consoultine firm.

Mr. Ieahn said thas "wo have not yex had an opportuntty to obenin commit. ments" for finuscing to complete th transaction with USAir. But he added the "we are contident the TruA will be able obetin the necesary

USAir tas oftered to byy pitemont tor cash and stoct is a transection valued a as much as 81.6 billiba. Mr. ICahn, in the letter to USAir. said thas "we belleve tha your other shareholders woukd prefer ou cash merter proposal for USAit over USAlr's proposed acquitedion of Pled mont." But he aloo sald. "Altomatively. we would be interested in discusering a threeway comboturtion amons USAr. Pidmoat and TWA."

Jultus Maldutu, an analys at Salomon Brothers Inc. sald "TWA's proposal is a ploy to have USAir turn around and buy TWA and to have USAir drop lts bids for both Pretise Southwea Artines and Pled. moat." USur's plan 60 buy Pacinc South.

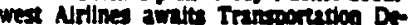
permens clenrise.

Other Wall Stret sources sald much th sam. Indend, TWA's shares row 20.25 to

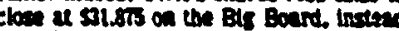
of talling as an acquirm's shire ofter. do.

In in interview yesterday, Mr. loath declined to discloes how mum USAir shares TWA has bourth. he suid be would do so la a Secunties and Exchan com miston tiling to be mide in a "timety

Wall Street sources said they under stood thas TWA now holds 9.9\%o of USAr' rock ousennding. They said the airlin has held 4.9\% for nearly a year and bourt the rex in the pax tew days. Securtice. 1aw requires a buyer of 5o or more of 2 publicly held company's stock to report the hotding 10 the SBC minin 10 days.
Mir. Icahn's proposal to t'SAir cume in a letter addressed in its shairman and gresident, Edwinn t. Cilociny. Mr. lcahn said thas if a "nezotiated transaction is 201 acceatable to you. we may make an offer dimetly to LiSAir's stareboiden tor up to $51 \%$ of LSAir's ousstanding stock to be purchased in a voung trust at a price lower that the 253 per share that we are propesents today."

In any case. the letter shid. TWA was astinc that the Transportudion Depurment clear both its acquiriton of USAir and its purcuse of st\% of the company's stock.

The Transporration Deparment has cleared every major alnine merser pro. posed in the part 14 years-somerimes al. ief orderins change Yestertay depart. ment ofifelals declined comment on TWA's proposel. as is customary.

In the past Mr. Icahn has relled on Drexet Bumhan Lambert inc., a New York investment bankep. for financiris commitments for his cakeover attempts. includine his ourchere of TWA. But a se niof Drsxel ofilctal said yesterday that MP.

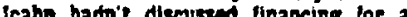
uSair lakeore source said TWA had access to some $\$ 900$ million in cach. Bus th tiritise would need mors to take over USAr.

Bedides controlites TWA. Mr. Icainn re tain $1411.4 \%$ stake in USX Corp. He ac quired the holdins with borrowing on which be is undetsood to be payng heth carryiar costs: TWA owns a small part of the interest in USX directly.

A combinados of TWA. Washingtonbased USAir, and Paciflc Southwes. San Dieco, orobably would create the nation s third-lartet carrier. According to tigure compited by Aviation Datly a trade pialicalion, the murter shase of the merged airlines would amount 10 about $12 \%$ in rev enue perencer milles sllently ahead of the combin shre of Texs Ais Con's Cond. nental Airing and Eathrm Airtines.

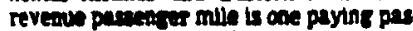
sentre cerried on mile.

The sound retbonl systems of USAir and Predmeol to finet whth TWA's inter nationil routes "would be a terribly pow. ertal combination" said Mr. Loward of Airtin Bcosonice. "That looks rery much like a standalos survive."

The ITA group could by tli airerat on

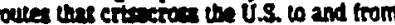
huls in Pitteburth. Putiedelphila, Los AN Petes Sin Francteco. St Louls and New Cort mating th a formidable competitor. "If the airtines could be put together with the employees under TWA's labo contracts - which would be eary to postu. late but dincult to accomplish - they could be a bir foree in the marketplace." said Paut Schlesinger, a securtites analyst at DL Securtues. But he sald. "I don't think the if will happen."

Journal, March 5, 1987, p. 1 A. 
PSA employees were in a daze. Not knowing who they belonged to, who to identify with, what happened to their identity to PSA, what would be in store for them in the future was puzzling and difficult. There had been no time to even experience the loss of PSA, let alone develop a new identity with USAir, or Piedmont or TWA.

What was reported in the Los Angeles Times added to the confusion of identity when it published later that week that USAir Group and Piedmont Aviation had agreed to proceed with a merger in which USAir would pay $\$ 1.59$ billion in cash for Piedmont.

The article went on to suggest that the transition was the latest and highest priced consolidation in the airline frenzy of the post deregulation era. Airline industry observers viewed the blending of the carriers, however, as an excellent fit because Piedmont operated mainly in the southeast while USAir's routes were primarily in the midwest and northeast (see Figure 30 ).

The proposed USAir-Piedmont marriage, which would create the nation's seventh largest airline company, had been approved by the directors of both firms but still had to be approved by stockholders and federal regulators. This ended several weeks of competition between USAir and Norfolk Southern, a giant railroad company, for the right to purchase Piedmont, which was based in Winston-Salem, North Carolina.

On March 18, 1987, another interest group approved 


\section{USAir, Piedmont Agree to Proceed With Takeover}

\section{By ROBGRT E. DALLOS.
Times Slaff Write}

NEW YORK-USAir Group and Pledmont Aviation, two profitable airline companies, said Monday they have apreed to proceed with a merger in which USAir will pay $\$ 1.59$ billion canh for Piedmone.

The transaction in the lateat and hirhest-priced consolidation in the airline merier frenty of the past-derepulation ere. The meahing of the two dometic carrient viewed by airline indurty obstrvers as excellont tit bectus Pledmont operete mainly in the Southeats while USAir? routes are primarly in the Midwest and Northeart

The price that USA, of Arlingron, Va. has afreed to pay for Piedmont is nesty double the seat aillion the Northmet Airlines paid for Republe Airlines lat year. the moxt contly airline indurtsy meger to have been completed so far.

The proposed USAir-Piedmont mar. rage, which will create the nation's sev. enth-largeet airline company. he been approved by directars of both firm but mut be blesied by stockholders and federal repulatore it appenre to end esvern weeles of competition between USAir and Norfolk Southeri, a dant railsosd compa. ny. (or the rt ght to buy Fiedmont, bered in Winton-Silem N.C.

And while that finte for control we

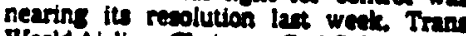
World Airines Chairman Carl C. Ieahn, in surprise move, confund matere by offe. ing to buy USAir.

Monday's announcemont appean is thwart Icthis' 11 th-hour attempl to mente
USAir, with its strons domestie route system, into his carrier, the bulk of whose business is on over. seas routes. But some analyste maintained that Icahn's effors to acquire USAir, with or without Piedmont, may not be at an end TWA, they contend. will have difficulty survivins alone and must find a merger partnes.

Mark Buckstetn, general couned for TWA, declined to comment Monday on the airline's plans. But TWA on Monday did file with the Department of Transportation an amended and more detailed appllcation to acquire USAir. An earlier applieation was denied late Briday becture il contained too littlo infor. mation.

"We're all waiting to en if leahn has another strategy, another move in mind" sidd Paul Rnow an airtine andyes with the New Yort brokerage hous of L.P. Rothschild. Unterter, Towbin "We'U have to see if lectin wants to betele it out."

Icahn, who sald lat wein that he had already acquired $15 \%$ of the stock of USAls wes termporinty restrained Mondy by a U.S. Dis. inct Court in Pitteburith from cequiring any more.

Under the term of the USAir. Piedmont merger agreement. which the companies ald thes agreed on Bridy nighe USAir

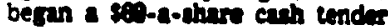
ofler for all of Piedinont's 22.1 million shrse of common rock outstandins.

The USAir cilce to a menened version of its entles proporits which were combinntion of ensh and tock.

In the peading morros exeh shar of piedinont commen tock not purchaed in the cender ofile. will be converted inte the ritht to recetre 19 pes ahrs in corh USAir's offer is conditioned upen the cenderins of bals of the share.

Figure 30. USAir, Piedmont agreed to merge. Los Angeles Times, March 17, 1987, p. 10A. 
the sale of PSA to USAir and the story was covered in a variety of newspapers. The San Diego Union pictured the voting meeting at the Westgate Hotel in San Diego, California (see Figure 31). The shareholders of PS Group .. Inc. and Pacific Southwest Airlines overwhelmingly approved the pending merger. PS Group Inc. shareholders voted $63.3 \%$ in support of the proposal to sell the airline to USAir Group. Shareholders of Pacific Southwest Airlines voted $91 \%$ for the merger. Approval by USAix shareholders was not required to complete the deal.

The reporter also noted that company employees who owned $8 \%$ of PSA through the employee stock ownership plan had voted overwhelmingly in favor of the merger. PSA Teamster employees voted 968 in favor while PSA pilots backed the plan $100 \%$.

Later in the month of March, 1987, the headlines captured the political fervor that was taking place in the Teamsters organization as it related to the employees they represented. The news stories indicated that more than $80 \%$ of PSA's 800 flight attendants having called for an election to replace the Teamsters union with the Association of Flight Attendants when the merger was completed. The National Mediation Board had certified that a majority of the airline's flight attendants signed cards requesting that an election be held to determine which union would represent the group. Additionally a large number of PSA employees had 


\section{Stockholders approve sale of PSA}

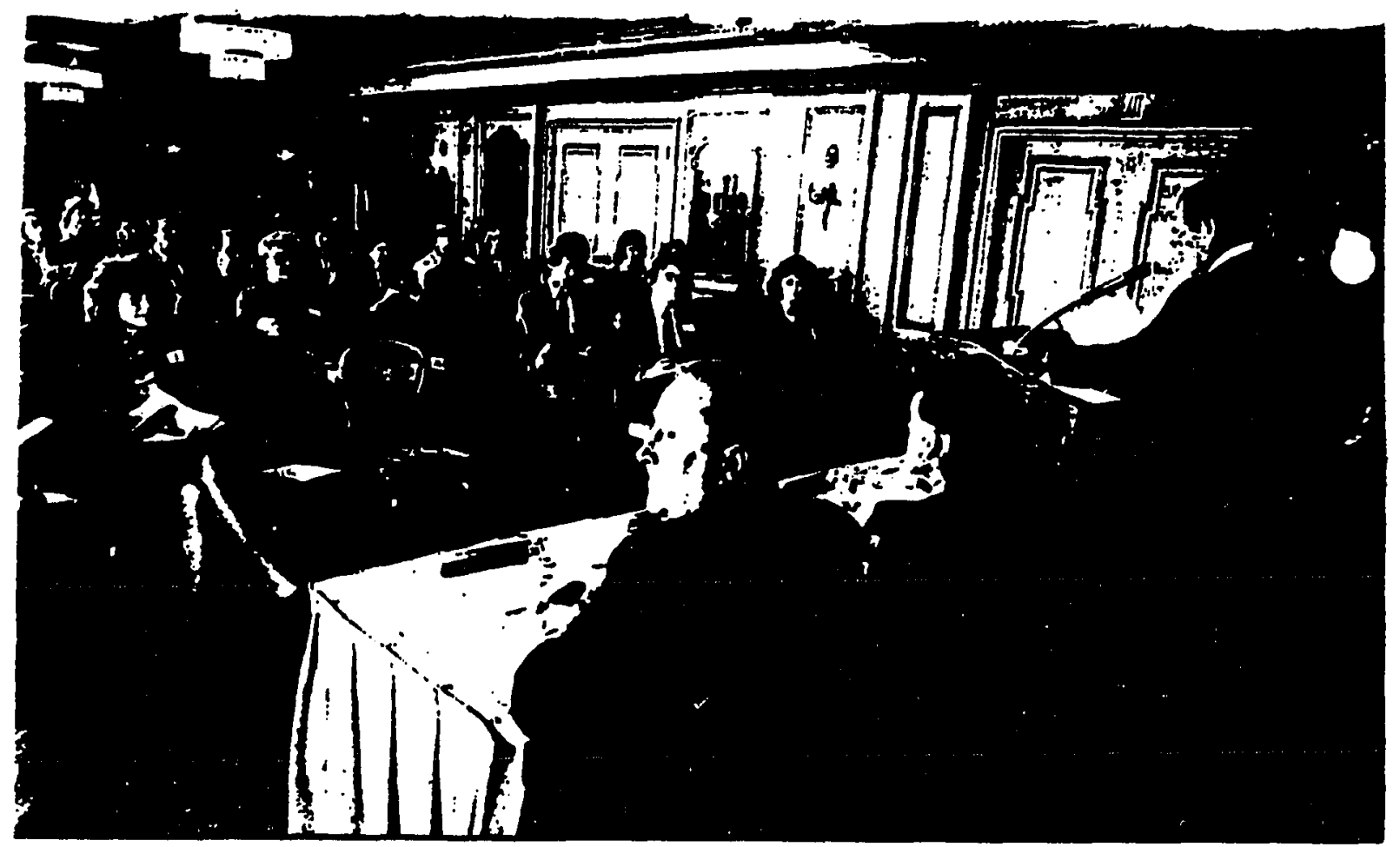

PS Group Inc. and Pacifle Southweot Arlines execuves share the rostrum during yeaterday's shercholders

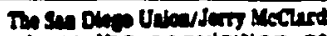
meoting at the Weatonto Hotel where the acquistion of the Sen Dicgo-baed airline by USAlr was approvad.

Figure 31. Shareholder's meeting at the Westgate Hotel in San Diego, California. San Diego Union, March 18, 1987, p. $7 \mathrm{~B}$. 
requested that the company stop withholding Teamsters union dues from their paychecks.

The Teamsters were being ousted! A grass roots effort to replace the Teamsters had begun when PSA employees were unable to get detailed information about the negotiations to modify the labor contracts. From the employees' perspective, the negotiations represented the most important talks of their careers and they were being locked out. In fact, employees had expressed their opinions to the union on several occasions since the merger was announced but had yet to receive a response.

A group of reservation agents, flight attendants, baggage handlers and ticket agents known as the "Committee for Fair Representation" had circulated a petition in January demanding that the Teamsters agree to the contract modification. The petition garnered the support of about one-third of the Teamster members at PSA.

Approximately $20 \%$ of the airline's flight attendants signed another petition in January demanding, under the Teamsters' bylaws, that a union meeting be held with the group. No meeting was held.

Furthermore, a group of 13 employees had sent a letter to the Teamsters' representatives demanding that the Teamster members be informed as to the issues agreed upon and unresolved. They threatened that the lack of immediate action on the part of the Teamsters union would give them no alternative but to consult with legal counsel 
in order to secure their rights under the law.

This unrest, which was felt and manifested by PSA employees, was realized by many special interest groups including, of course, the Association of Flight Attendants (see Figure 32). The AFA was, at the time, the majority union for the nation's flight attendants, representing some 23,000 workers on 14 airlines, including USAir. The AFA began gathering union election cards from a group of obviously disgruntled and confused employees. This was a time in which a new coalition could easily enter into an arena filled with emotionalism and possibly win the right to represent.

During the month of April, 1987, the press presented the PSA-USAir merger from a political lens. Iike a suspense movie, the events that were published in April were highly climactic.

As the news was released about PSA's and PS Group's financial losses for the first quarter of 1987, and with the tension extremely high among interest groups, PSA employees were distracted.

Pacific Southwest Airlines had reported a $\$ 6.5$ million net loss and PS Group had reported a $\$ 7.3$ million net loss for the first quarter of the year. During the same quarter the year before, PSA had lost $\$ 10.9$ million and PS Group had lost $\$ 9.9$ million. Even with lower fuel costs in January, February and March of 1987, and even with increased passenger traffic created by discount fare 


\section{Assn. of Flight Attendants Seeks Election at PSA}

\author{
By GRDE JOHNSON. \\ Times setf Writer
}

SAN DIDCO-The Amen of Filigt Attendence union hes setzed the Natbond Medintion Bourd is hold in elcetion thas could lum out Toamiten Union Locel 270 as the burnining seat for Pactic South.

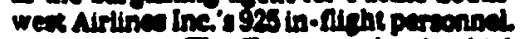
The Tenmine loent which

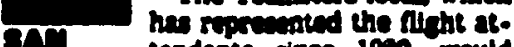

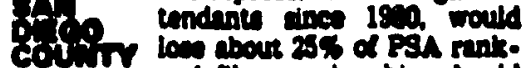

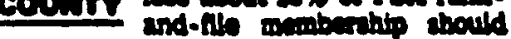
AFA wis the riprenenention eloction in

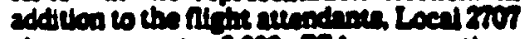
ats roptents 3000 PSA revervation

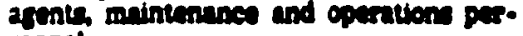
sonnel.

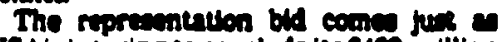

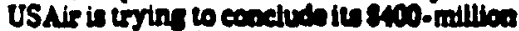

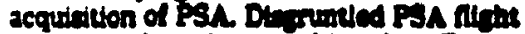
attondente tave boen puiniag thet Teles. sters leadres to approve contract modiber. tions being deminded by USAtr as part of its bid for PSA, scectitios to unice mers. bers who acted not w be nered

The contract netion USAir weats mod.

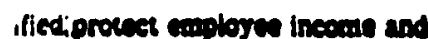

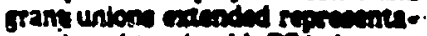
ikenit righe should PSA be co. yuired by anothe airline. Fas: flo. phlute who of repenated by

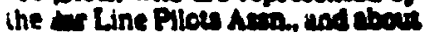
50 emplayere ropresented tos imo im it. unons nave arew to modity ther unon contrines a dermanded by USAir.

Solm. PSA bas bean unable 10 neciline contract modiflentions

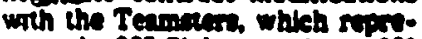
sementhe 925 firthe atuendares 981 maimenances and member l.4M

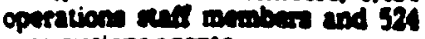

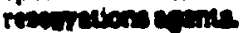

The falure to negotinte an

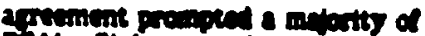

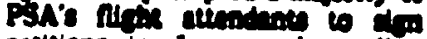
petition in Janus dumpen ins the Tenme sin 10 th laber conerse modthention do. manded by Usur. A croup of PaA

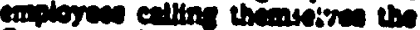

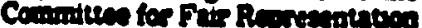
erreulated the pentitent winich

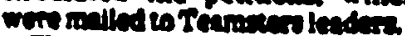

The APA is the meintery unim

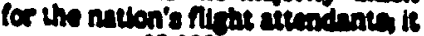
repreverie 20.000 wortose on 14 airlines including USNir. The ATA

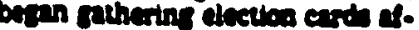

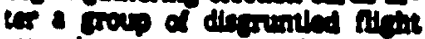
attendants represented by the

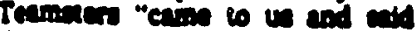
inoy wated to be corengted by AFA" ald AFA poiremenen Judy steet.

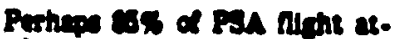

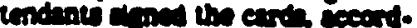

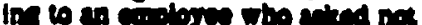
wovichation

A dimple on'sity roen would bo mapared to enll an whetiven and is

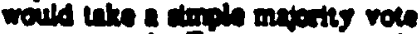
w turn out the Temmen econde

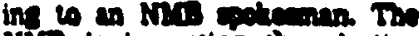

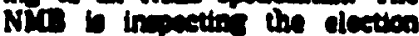
card un Ars colneted bet in

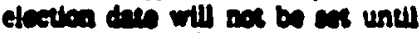
crea the boend dockinines where.

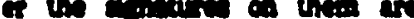
lefitimale, the popotemen ald Wedneedey.

\section{Figure 32. Association of Flight Attendants seeks} election at PSA. Los Angeles Times, March 23, 1987, p. $10 A$. 
programs, operating costs were still high. PSA was weakening.

If the USAir takeover did not occur, PSA would be forced to substantially alter the course and scope of its business. A down sizing contingency plan was being structured in the event that the deal went sour. PSA would never be the same as it once was.

USAir and PSA had agreed that either party could abandon the relationship if the merger was not concluded by April 30, 1987.

Time was running out. Although PSA had negotiated labor contract changes with its pilots and two smaller unions, negotiations with the Teamsters had broken off. On Friday, April 17, 1987, the Pittsburgh Press headlined that the talks between PSA and the union had been stalled and that the merger was now in doubt (see Figure 33). The talks had collapsed essentially because the Teamsters had demanded that PSA set up a $\$ 5$ million trust fund under the Teamsters' administration to provide severance benefits to employees who might not want to relocate after the merger. PSA offered to place $\$ 1.6$ million into a fund that would be administered by independent trustees. Additionally, the Teamsters demanded that wages of PSA employees be increased to those of USAir employees in comparable positions. PSA executives concluded that the new demand was inappropriate.

Teamsters represented employees of PSA wanted to vote 


\section{Union-PSA talks stalled; USAir merger in doubt}

\section{B) Bernie Eohn \\ The Pltesburgh Prone.}

The chances of the USAir.Pacifie Souchwese Airlines merger fallin chrough have increased because of breakdown in nezotiations betweet PSA management and its Teamsters union on contract changes mantated by LisAir.

Talks sulled yesterday when PSA management rejected two conditions set by Teamisters Local 2707 tions set by Teamisters Local 2707 PSA's 5.250 employeed - lor zivias up its contrattual right to represent PSA employess after the merger. No rew valls bave bean scheduled, and each side yesterdiy cealled on the other to make a concillatory move.

The Teamsters demanded that PSA set up a is million truss fund. under Teamsters admiaistration, to provide severance beneflts $10 \mathrm{~cm}$. ployees who decide not to relocate after tbe merzer. PSA olfered to put si. s million ioto the fuad, and insist. af that it be admunistered by three :- Lependent trusteat.

Also. the Teamsears demanded that wase of PSA employees be increased wo thour Tor USAir employ ees in comparable pouttone A wion spokesman yesterdsy said that was intended as a "compromiso" to its earlier demaded that PSA retroen ij:ely restore the 15 perceat wase cuts that employen atresed to in 1984 to make the aiflibe more competitive.

But the company; which says the lower wages are vital to kespin PSA competilive in the saturate? West Cosu marteth mainuiared that the new demand was more coully than the tirst cees "Our peopls calle (Lalks) off wten is became apparto we were gettias sonteres on the wape issas." comping spokeamas Bill thastors calde.

I USAir bue vownd to eali oft the

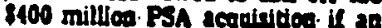
- aprement with the Teamstars is nos reacted oy Aprall 3a. The merter already his bres approved.by the federal sovoroment and PSA stock. boldars and Pan' other unione pre viouly apred to contract changes requeted by USNir.

"Fo have anes their dermad "s sid

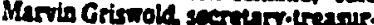
ex of cocal 2707: "If tura, what Te're sayton is Trase to PSA

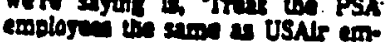
ployectin' All we're looking lor is equality."

"Wo've drea up some pretty sub. stanthal provisiogs to this point to make thl deal happen." Griswold added. "To've beat ores bact wands to get to this poiat"

Griswold insisted the wasts io see the Eerfer complated. ad denied

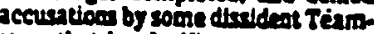
sters. that local officess wes inter. ested ooly in protectios their positions "To're interested is setios employes treated fairly. Mere's aothing is it for us." bo suld Tothe is is for us " bo sald themsalve the Comnilte for Fair Represectution stapped up their op. poition yesterday afte hearios. abous the braktoons is talles.

Group nombers ind by niets attzadaats, collected s/guatures trom contrits at severil Callior. in arperts on i pelifion demandios that union leadar drop their corsthat union leaders drop their comspeasatlos demands. The croup

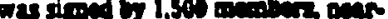

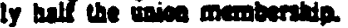

\section{Figure 33. Union-PSA talks stalled. Pittsburgh Press,}

April 17, 1987, p. 6D. 
on the contract proposal as it stood from PSA's point of view. The union officials said that if the two provisions set down by the union were not met, then a vote could not be held. Furthermore, the union's proposal, inclusive of the two provisions, could delay the merger for at least 30 days, putting the April 30 deadline to test.

In San Diego, the headlines stated that unhappy union members wanted the PSA contract offer put to a vote (see Figure 34). The union members and officials of the union were in enormous conflict. It was becoming crystal clear that the wants and needs of the followers were not being met; in fact, those wants and needs were being ignored. The Teamsters union was under severe pressure from its members to conclude the negotiations which were essential to the company's merger with USAir.

Finally, the Teamsters officials said that they would submit the company's final offer to a membership vote. The union's announcement, however, came as over fifty PSA Teamster represented employees picketed the Los Angeles, California office of Teamsters Local 2707 while simultaneously threatening to take legal action if the union continued to block the merger (see Figure 35). This was the first time in history that union represented employees picketed their own union!

With only one week left until the April 30 deadline, employees of PSA were in a turmoil that moved them to anger over the Teamsters' actions. The union members 


\section{Unhappy Union Members Want PSA Contract Offer Put to Vote}

\section{By GREG JOHXiSU.T. Times staif Winter}

SAX DIEGO-A rroup of dissident union members wants Teamsters lision General President Jackie Present to force Local 2707 to submil Pacific Southweat Arline" lateat contract proposal to a ratificution election by PSA's 3.000 Teumsters-rupre. sented employeen. The disgrunded Teamstere
some of whom on Tuestay sfy. picketed the Teamaters' Lo coufir Angeles office buidenc. "want the intermational lead re hip 10 be held accountable for what is hasomng" at PSA according to Crais Schiom an atcorney who reprowents the tous.

The call for a spenil electiod fallowe. Loct zTor's dectemon not 10 submit PSA' lated contrest ofler to a ratufiention eleston unlew PSA modifles two sectuons the deal meh a propend soverance pay and outplectune truns tund.

In a related developenem Wodneade nighe PSA sud it had restred a counere

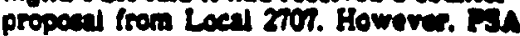
spokenmen Bill Hexune and Laed stu
Secroupy-Tresurer Marm L. Grumold deslined to comment on the contents of the Teamsens' offer.

The contract moditication bang cought by PSA are imporente besum USAur has pledred to abandon ies 210 -million bid for the Sen Diego-based arline if PSA fail to negotinte the contract modificatsons by Thureiny.

The modifled Teansters contrets, cov. enne 3.000 PSA flighe atendints meches. ice. fround personnd and resmvetions agnath are the only remuning brrits 10 the mas ov. according to Hasthy-

Thres other unions repreanetns PAA employew entice apporved the neaded contros modifieation. Shmonoldes of F3A and ES Group the airtinde perme company. have voted to sill the dirtine. Fediel and state rulaten have Arn the nerout the cron lighe.

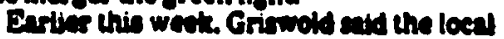

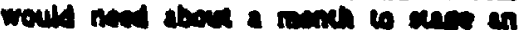

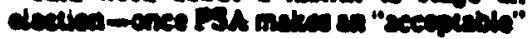

offer. Consequmenty. Gnswold saud Loeal 2701 has asked CSAir and PSA to extend thers merger agree. ment to make a vote poseable.

PSA mantains that the Team. sters can complete an election durnng the seven daye remaning before the desedins. Hiatings sad Thureday.

The disgrunted Teansurs aro peritionin Preteet becaues" .. he has the authonty to call tor an election." sud Schloas who added that intecnationd unions have in the pan tound out locel leadershyp "when it aided the welfare of the memberahip"

Envilies on Thuraday. a rroup of Teammere picketed in (ront of the P3A vicker counter at Lundbergh Field in a show of suppors for Lxal 270r s leadership.

The Teamrters demonstrated for about half an hour because "we're tired of the fight atcondanis' say. ing thet they'to ous spokesmen." accorting to cons of the Teamsters.

Figure 34. Unhappy union members want PSA contract offer put to vote. San Diego Union, April 1987, p. $14 \mathrm{~A}$. 


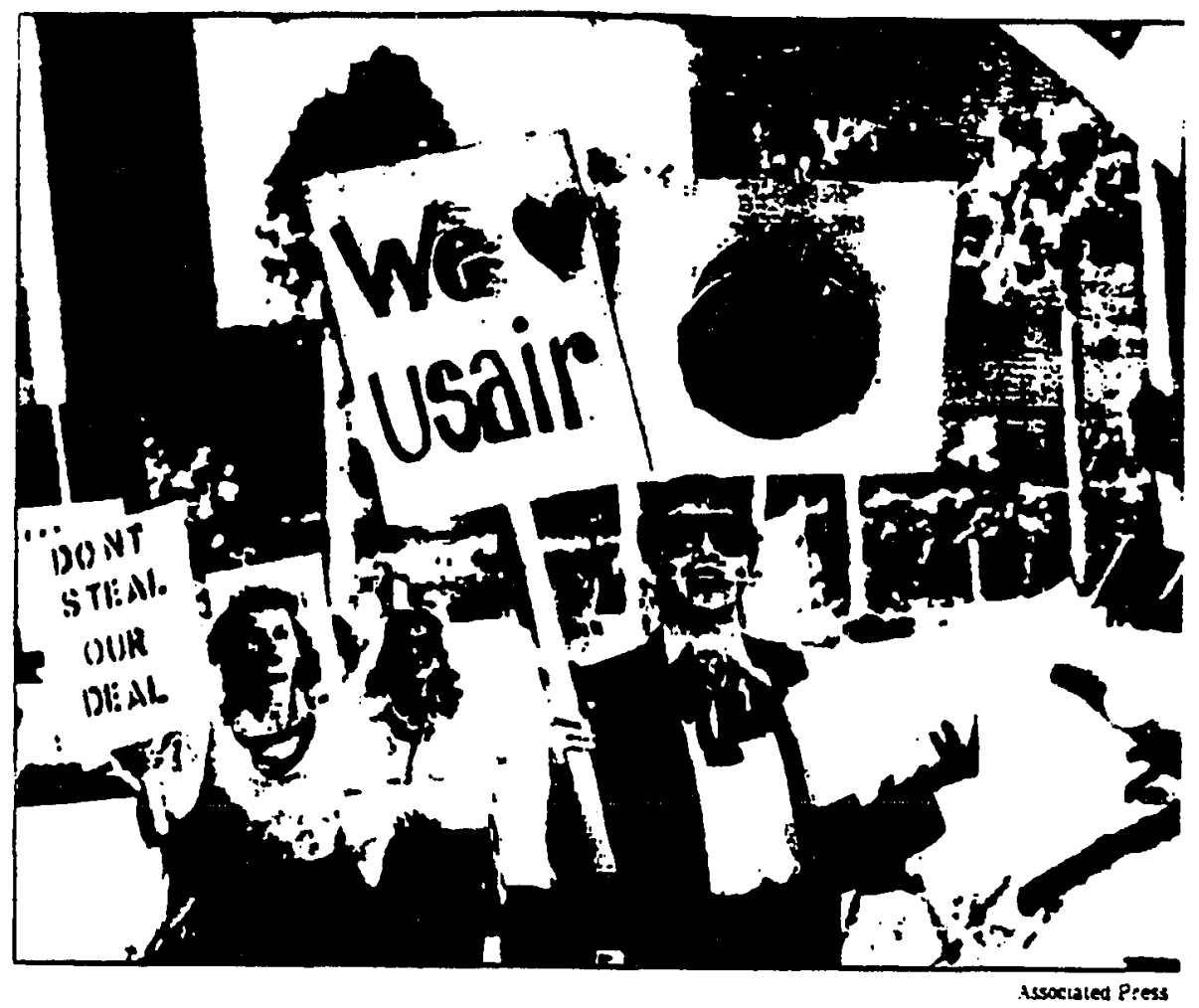

Pacific Southweat Airtince Teamster. Los Angoles office to protest lack of progrepresented employess picket the union's ress in contract negotiations.

Eigure 35. PSA Teamster-represented employees protest lack of progress in contract negotiations. San Diego Union, April 1987, p. 9D. 
were placing constant pressure upon the Teamsters through aggressive communication and picketing.

Just one day before the deadline set by USAir, a tentative agreement had been reached between the Teamsters and PSA. As such, USAir group had agreed to push back the April 30 deadline to May 17,1987 to allow for ratification of the last minute agreement.

The stalemate was broken when the union removed from the bargaining table the request that PSA employees be given immediate wage parity with their counterparts at USAir. PSA employees earned $14 \%$ to $30 \%$ less for various jobs than workers at USAix. Comparable salaries, however, would be reached over a three year period. The April 30 , 1987 article of the Los Angeles Times (see Figure 36) details the events described.

Between May $1-17,1987$, while secret ballot voting was taking place by the 3,800 Teamster represented employees, a calm was in the air and a hopeful attitude prevailed among PSA employees. The anticipation was high since most employees felt that the voting process would be in favor of the contract changes.

The press waited. News tended to focus on the status of PS Group, particularly since the sale of the airline to USAir for $\$ 400$ million would bring $\$ 280$ million in cash to PS Group. Essentially, the PS Group would be a $\$ 594$ million company after the merger, involved in gas and oil exploration, airplane leasing and jet fuel sales. 


\section{Union Accord Clears Way for Purchase of PSA}

\section{USAir Extends Deadline to Allow Teamsters Members to Ratify Contract Changes}

\section{By GREC JOENSON. Times Staff Writur}

SAN DISCO-Paelife Southwert Airlines and Teamreers Union Local 2707. which repreante 3,800 PSA employew. resched cencative agreement Wodnesday on labor contract changes that clear the way for USAir Group to conclude ite

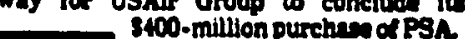
3400-million purches of PSA.
The tentative afreement 9.7 The tentative atreement ctot in deadline sen by USAir. which coniv had threaterned to aberidon the ded if Sen Dieco-baned PSA lailed to negotiate modiffeacions in labor contrects with unions ropresenting 4.800 of its em. ployeer. USAir on Wedneaday extendad that deedline untl May 17. USAir spokesman David Shipley said. to allow ume for Teamisters members 10 vote on the apreements

The contract changer were argead to by the leaders of Local 2707 and now muat bo ratilied by 3.800 Teaniturs-reprewented PSA employees at 28 locations in dx menter. The union is likely to hold the vote by elephone in ordes to meet the Mny 17 leadline. Local 2707 Secrecary-Treanure Marvin L. Griswold sand Wednendy.
Final agrement by PSA and the Teamiters is the only poanble roadbiock in the paih of the merger. Three other inions representing PSA employees have already agreed to USAir's demands and airline shareholders and federal regulacors have approved the sale.

The Teamsters have centatively agreed to drop so-called "successor clauses" in four contracts covering PSA's flight at. sendanes. mechanies. station agents and reservations agente The contracts had guaranteed that the union would continue to represent its members after a merger with USAir.

The Teamnters represunt just 1.500 of USAir's 15.700 employees and it is now unlikely that the union will represent present PSA employee after they join USAir when the two carriers merge.

USAir's night attendants are represent. ed by the Asm of Flight Attendants and it mechanies by the Intermational $A$ sen. of Machinists. USAir's bagzage handlers, reservations agents and round perconnel 250 not represented by uniona.

In return for their areoment. the Team. sters said they nepotated a 83.2-million trum fund that will make severtance pay. ments to employees of both PSA and USAir who do not accept out-of-town transfers brought about by the merger. The fund will also help pay for out-plecement services.

\section{stath of reilice}

PSA employeen were "breathing a collective sigh of relief" when wosd of the tentative arovment went out shortly after I p.m. Wedneady, according to Robd Mccord, a ticket counter employes at John Wayne Airport in Orange County. "This was the lant mijor hurdle, the lan monkey on our bacte a far a this ded goins through." she said

Figure 36. Union accord clears way for purchase of PSA. Los Angeles Times, April 30, 1987, p. 9A. 
As voting continued, the emotional drain upon PSA employees from three months of highly political negotiations carried forward. There were 92 meetings of union members held in 28 cities. The meetings were held to answer questions and to vote on the issue. Dialogue between the union and its members almost did not exist, especially since under the agreement the Teamsters relinquished contractual rights to represent PSA employees at USAir. This issue was the most hotly contested concession sought by the airline becuase it made the Teamsters a moot point, even though PSA employees would continue to be represented by the union until the two airlines were completely merged.

On the morning of May 18, 1987, the news revealed that the Teamsters voted in favor of merging with USAir. As outlined in Figure 37, the voting results showed that reservation agents had voted 350 to 67 , flight attendants 621 to 10 and station agents 934 to 155 to support the plan. A bit more surprising were PSA mechanics who voted 388 to 377 for the merger, a difference of only 11 votes. Nonetheless, the PSA-USAir merger was supported.

The party had begun the night before at 10:45 p.m. when the results of the Teamsters' vote of the PSA-USAir merger were shouted out a hotel door. PSA employees waiting outside embraced each other and rushed to tell coworkers that the once shaky merger with USAir would fly after all. 


\section{PSA 'l'eamsters vote to support USAir merger}

By Carl Larsen

Tribuas Aseisuat Fianocid Editor

LOS ANGELES - Teamster employees of Pacific Southreat Airlines have cleared the nay lor PSA's 400 million merter with USAir Group ine, officials of the union said here this momion

"It's on," said Marvin Griswold, secretary-treagurer of Local 2707 of the Teamsters Uaion, which represents

PSA's Dight attendaats, mechanics. station and reservations agents.

Approval by the union removed

the last burdle to the merger, which

is expected 10 be completed on May 4.

A vote count on the mercer tallied there late last night showed unice members overwhelmingly in support of the dest which was firs an nounced lust Deces.

The Teamster balloting, conducted at union meeting bepinning May 4 showed a vote 2,293 in favor of the mercer arrecenent and $60 s$ arinst, a spokement for the uniog sid

PSA bas 3,400 Tearnster emplos. ees out of a wort force of 3.700 .

Victory, however, was not as earily gained as final vote tallies indlcate.

While the cumulative Teamster vote was strongly in support of the merger, balloting by PSA mechanics nearly threatened to put the deal in jeopardy.

The mechanics voted $386-377$ for the merger, a difference of 11 votes that could have denied approval to the deal since support was needed from each of the four Teamster bas. gaining groups.

Other groups represented by the

Teamsters voted solidly for the

merger. The results showed reserva.

tion ageats voted 350-67. night attendants 681-10 and station ageats 934-15s to support the plat.

"We're very pleased by the support shown by our employees for this acquisition" said Paul C. Bartley, PSA chairman "The acquinition of PSA bs USAir Group is a tremeedous opportunity for PSA and its emplojew to be vital part of a major cartier in this industry."

The mercer of San Diecobared PSA and USAir of Arlington, Van ensller had won quich approval from the Iederal Departaneat of Transportation and from PSA's three other uniom.

Word of the Teamsters approval quictly paesed outuide from the room in the Hyate Hotel venr Los Angeles International Airport where the ballots wert counted

"Fe got it"" yelled oes jubilnat PSA employes who bad been awaiting the outcons.

Figure 37. PSA Teamsters vote to support USAir merger. San Diego Tribune, May 18, 1987, p. 7B. 
First on someone's list was USAir Chairman Edwin Colodny. One flight attendant asked for his phone number so that she could be one of the first to inform her new boss that Colodny had just bought an airline.

As the champagne flowed in the hotel room set aside for the occasion, PSA employees on the Committee for Fair Representation reflected on their effort to push through the USAir merger in the union vote. Much of the admiration and credit went to Carol Austin, an up until then unnoticed leader of the group and a PSA flight attendant. Shouts came from across the room to include, "You saved by job," and, "We're employed because of you." Austin was the initiator of forming the Committee for Fair Representation.

After May 18, 1987, news articles regarding PSA dramatically subsided. San Diego's hometown airline was merged with USAir Group, Inc. It was suddenly business as usua1.

The San Diego Union of May 29, 1987 pictured PSA ticket agents at work at the counter they then shared with USAir at Lindbergh Field (see Figure 38).

One more story was written about the PSA smile on June 17, 1987 in the San Francisco Chronicle (see Figure 39). This article summarized that PSA would lose its corporate identity in January of 1988 , but that the grin would remain for awhile.

Once the highly political activities of the change 


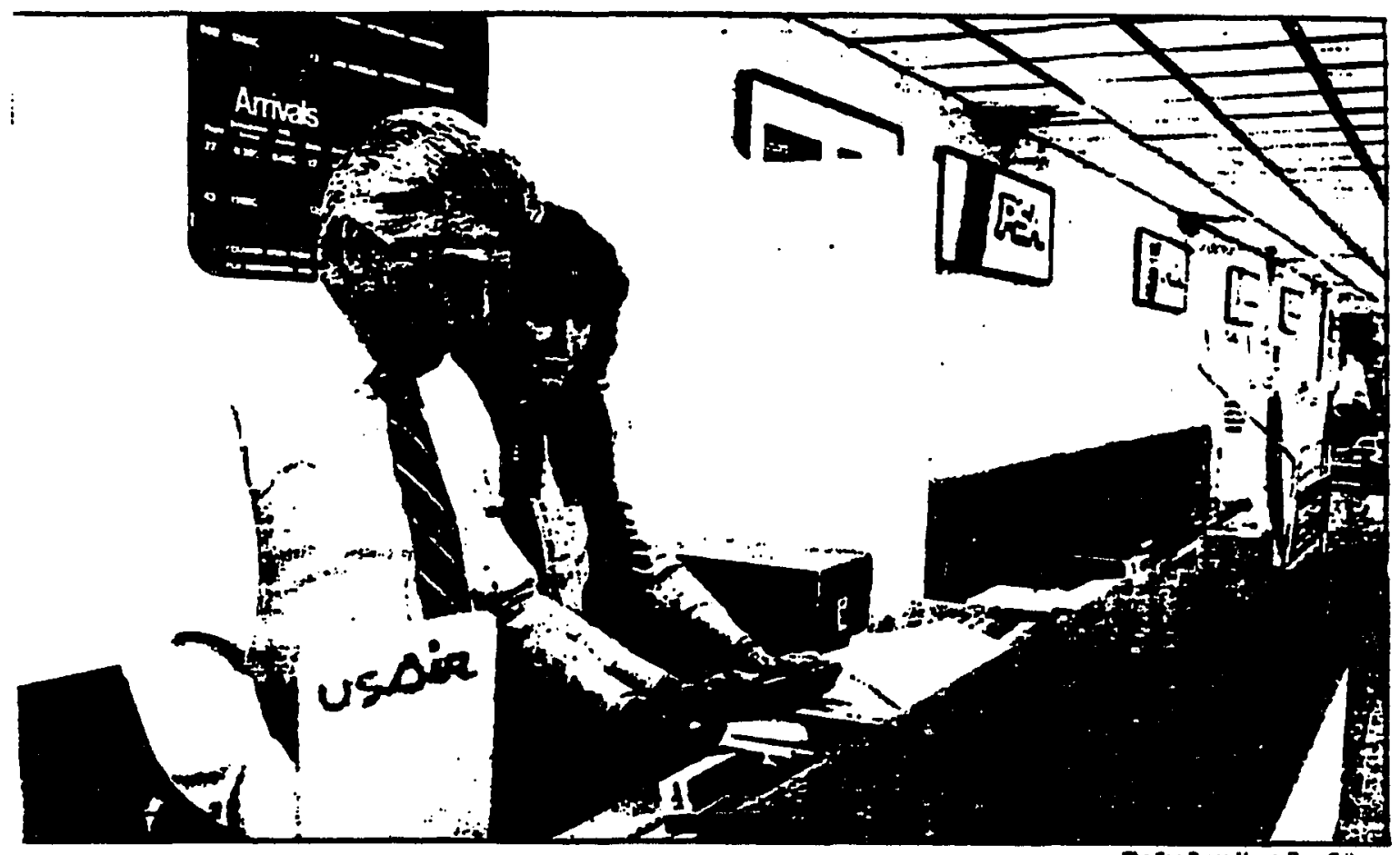

The Sue Deeso Liasen/Rum Gibert

PSA ticket agents Paul Barden, lot, and Terry Lewle Lindbergh Field. PSA employees are reaponsible for prowork the new counter they now share with USAl at ceseing paseangers on USAIr's two daily flights.

Figure 38. PSA ticket agents share counter with USAir. San Diego Union, May 29, 1987, p. 9B. 


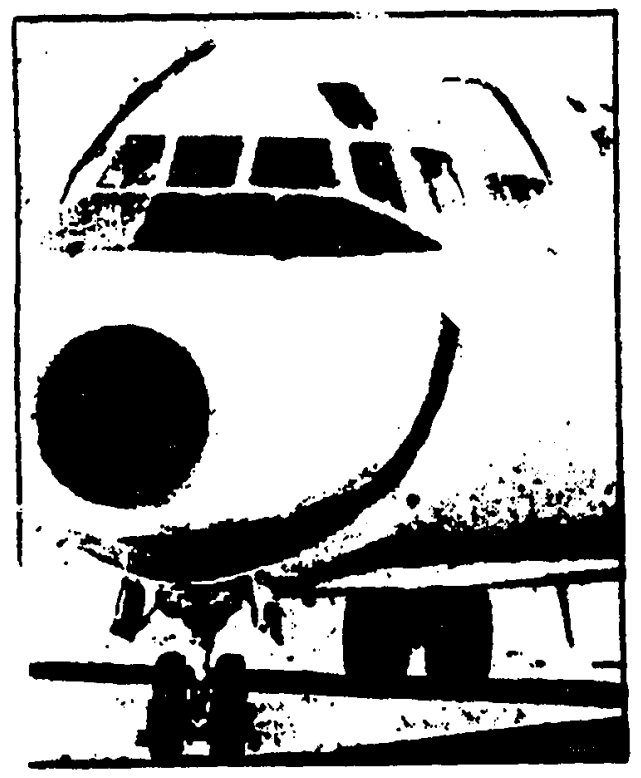

\section{PSA Planes May Keep on Smiling}

PSA will lose its ideatity next January. but the airline's planes will probsbly keep on smiling.

According to an executive of PSA's new pareat, USAir, the tamillar gria will remaln on alt the planes even alter they ase repainted with USAlr's loge.

The word comes as USAlr propares to begth ruantar ade tomorrow bocatiag its receat pur. chese of the San Diesobeced alitine with the slores, "Introducing the state of our union." PSA will bo opertied as an ladepenedeat subdet iny of USAlr undl yearead.

Brins Dryes, USAlr's vico preddeat of sales and advertining sleo ald USAir woa'l reduce

the frequent schedules operated by PSA.

Analystu say USAir is smart not to tinker with PS.I's established trademarks - its smile and tre quency of tlights.

USAir still taces plenty of chal. lenges though. Its main onc is to find a way 10 compete with the huge automated reservations sys tums of United and Amertean. its archrivals on Hay Arestlo-Los Angelos Algher.

USAtr in studytog options that Include creating its uwn comouter systum to teuming up witb an atro line that already own obe, such as Trans World Nellnet If will be 1 th yeers bofore a dociston to nagde. I's Nir ald.

Figure 39. PSA planes may keep on smiling. San Francisco Chronicle, June 17,1987, p. 6A. 
event curtailed, so did the press coverage. The press viewed the change event predominantly from a political lens. The dramatic halting of news coverage after the political fervor stopped would suggest that the external mechanisms for articulating this change provided primarily political snapshots of the event.

\section{The Programmatic Processes}

This researcher was the primary initiator, designer and implementer of this third leg in the overall five legged change strategy. The researcher believed that some intervention would be absolutely vital with the managers of PSA so that development, knowledge, education, skill building, technique building and understanding of the change could take place. Without this education and understanding the running of the business during the six month transition period would be in jeopardy, productivity would plummet, and the possibility of the merger not taking place at all could result.

As a member of the change strategy planning team, this researcher presented and persuaded all other members of the team that it was in all our best interests to invest in a custom designed program for all PSA's managemers and leaders. The program was geared toward how to lead in changing times; as such, the program was called "Leading in Changing Times."

The program was written and designed exclusively by the researcher. The one day workshops were facilitated 
solely by the researcher during March, April and May of 1987. A total of 16 one day sessions were conducted with at least 30 to 35 participants in each class. Classes were held in hotel meeting rooms in San Diego, Los Angeles, and San Francisco, California. Essentially, all PSA exempt managers attended.

The objective of this intervention was to help PSA managers not only so the business would continue to run, but so that managers would not feel the stresses, pressures, and frustrations that are associated with the type of change that a merger process inevitably causes. Furthermore, this type of forum could greatly assist the managers in seeing the change from a broader perspective. To spend a full eight hour day with colleagues in a structured intervention was a time out from the day-to-day uncertainty at work which would encourage managers to help themselves and their employees to see the change from as many lenses as possible. It was an attempt to broaden their knowledge base and their thinking about the event that impacted them so much. Due to the fact that PSA truly cared about its people and its business, the program was unanimously approved.

The overall change strategy was building multiple lenses. This intervention had value especially when it is viewed collectively with the other interventions instituted at PSA to help its employees. A building block approach to broadening views was shaping. 
This section of the qualitative case study describes the basic beliefs of this researcher as it relates to the programmatic process, the needs analysis which was conducted in order to design the programmatic process, and the content of the programmatic process itself.

The Basic Beliefs

Several basic beliefs on the part of this researcher prevailed in this change category. At a time when change was becoming a way of corporate life, human resource executives must learn to support their clients in understanding the dynamics of change. While there are many well-developed approaches to managing complex change such as a merger or acquisition on a rational or systems level, what was missing were equivalent actions from other change models that help affected individuals stay on track in an efficient and productive way.

In response to this perceived need, a collection of ideas had been formulated which could be used to help individuals as well as organizational systems cope with changes as they take place and recover from major changes more quickly once the changes are in place. If human resource approaches can help make change more understandable and less fearful, employees may in turn have more incentive to focus on the opportunities that the change offers rather than on the resistance uncertainty often engenders.

One of the basic beliefs that this researcher holds 
is that any change experience has elements of predictability. From day to day, individuals may find themselves oscillating between positive and optimistic views of the change to views that lead to feeling overwhelmed, helpless and unproductive. This period of passive or aggressive acceptance or resistance depends upon numerous factors including (1) the degree to which the change takes a person by surprise or places one in an uncertain or unfamiliar situation, (2) the degree to which the clarity of expectations about the outcome of the change are expressed, and (3) the degree to which data and information about the change is made available. In any event, one can easily predict that most people will naturally need to flow through some transition period. Another basic belief was that when strategies are implemented which broaden the understanding of those being impacted by the change, then the time of resistance, uncertainty and unproductiveness can be shortened.

Lastly, and very specifically, this researcher believed that if eight distinct ideas come together in a structured intervention, a person can lead other people and the organization more effectively through change. Those eight ideas are:

1. Managers and leaders must fully grasp that change is an integral and significant part of the way they manage and lead.

2. Often, organizational changes are triggered by 
some event or action and can therefore be predicted.

3. There are natural human resisters to change, which if understood could be instrumental in helping managers through change and in helping managers help their subordinates through change.

4. There are so many change events in our lives that we must learn to prioritize them.

5. Managers need to learn not only how people will react to change, but also to learn how to recognize reactions of people having difficulty going through change.

6. Managers and leaders can increase their effectiveness if they know how to overcome resistance to change.

7. If managers have clarity as to what their company expects from them in times of change, uncertainty will be significantly diminished.

8. There are change implementing actions that can be taken during changing times which can favorably influence productivity.

Each one of the previous eight ideas alone or separately do not necessarily have overwhelming merit. All of the eight ideas interrelated to one another, collectively, presents a powerful framework from which to design a programmatic process. The programmatic process also, however, needs to encompass the perceived needs of the learner. 
The Needs Analysis

There were approximately 500 supervisors, managers and directors at PSA during the time of this case study. In general, a supervisor is defined as someone whose staff members are primarily front line, contract or nonexempt, a manager is someone whose staff members are primarily supervisory or exempt, and a director's staff consists of managers. This population of PSA's managers and leaders was the target audience for the programmatic process being discussed.

The researcher determined that it would be very helpful to the design of the program if some feedback could be collected about what concerns the managers were having with the change, what difficulties they were experiencing while adjusting to the change, what difficulties their people were having and what resources and information might be valuable to them.

A series of informal discussion groups were formed so that some feedback could be received and ultimately incorporated into the design of the workshop. The purpose of the discussion groups was not intended to have been quantitative in nature nor highly scientific in scope. Rather, the discussion groups were intended to provide a feedback loop and an input opportunity so that the design of the course would be on track to the learners' needs as much as possible.

Three discussion groups were scheduled with eight, 
seven and ten members, respectively. The researcher was the group facilitator.

The meetings started with an objective which was simply to gain insight into how the change process was being viewed. Specifically, the managers were asked to respond to four open ended, discussion questions:

1. What concerns do you have as managers and leaders of PSA about the merger?

2. What difficulties are you experiencing while adapting to the change?

3. What difficulties are your people having while adapting to the change?

4. What resources and information might be valuable to you and your people to better adapt to the change?

Functioning in an advisory group role, the group members openly expressed their views regarding these questions while the researcher recorded responses on a flip chart and in field notes. Each meeting lasted approximately two hours. Comments were extracted from the flip charts and field notes which reflected common theme responses.

With respect to the concerns the manager had about the merger, a common response was: "What concerns me most about the merger is that we were not prepared enough in order to help our employees overcome the resistance to the change. It is our role to assist our employees in accepting this shocking reality that PSA will no longer 
exist. It concerns me that there was no plan, or no training to allow us to function better as change agents. There was no attempt made to prepare a plan. Without a plan, it's difficult to see the steps that will be taken to get us to the end result. We need that preparation." Another common response was: "What concerns me is that I don't know what I'm supposed to do, what expectations the senior management of PSA and USAir have for me. I don't understand my role in the change. I know my job and what's expected of me there, but I don't know my job as it relates to the merger."

As to the question related to the difficulties the managers were experiencing while adapting to the change, the following comments are representative of collective feedback: "The difficulty I am having is the culture shock. I am saddened that PSA, my company, will be gone. All of my career I have worked hard for PSA and now PSA will be gone, melted into some entity called USAir which I know nothing about. I am emotionally upset that PSA, the smile, the personality, the family will be no more." Other managers said: "The difficulty I am having is my own resistance to the change. I am resisting the unfamiliar and trying to hang on to what I know. USAir is unfamiliar."

When asked about the perceived difficulty that the manager's staff people were having with the change, comments centered around: "My people don't know who is 
telling the truth about the change. The company has started an aggressive communication plan and the union is saying other things. Rumors are rampant and no one knows what to believe or who to believe in. Their difficulty is with sorting out all that is said from the PSA USAir Merger Update, to conversations in crew lounges, to remarks from union representatives. When anyone gets opposing information, it causes mistrust. I really don't think our employees know who to trust. That alone causes discomfort and confusion."

Other significant feedback focused once again on the identity issues associated with PSA becoming USAir. "MY employees are unplugged. Their identity is so wrapped up in this airline that not being tied to PSA is frightening for them. Most of my people have been here for a long time. Their difficulty rests with the fact that it feels like a death or a divorce or something. They are mourning; yet there is an anxious curiosity formulating as to USAir."

The discussion which took place as to what resources or information would be most helpful to managers and subordinates alike was overwhelmingly consistent, and the remarks went like this: "We need some training to learn how to deal with all of this. We don't have any experience with mergers so we can't wing it on past experience. We need help in understanding the how tos of this type of circumstance. We want to act and feel in 
charge, not act and feel like we've been betrayed. With so many mergers and acquisitions taking place in the United States today, it would seek like there would be something out there to help us. We need tools!"

other common responses about resources can be summarized in this remark: "We need information on the whys. Why are we reacting this way? What is it about the nature of the change which makes us feel so lost for awhile? Why do we naturally try to blame everyone else for what we think is an unfortunate thing. We need to understand how other people in similar situations reacted. If I understood why $I$ am feeling so uncomfortable, I could help myself and my staff. If we don't get these answers, we'11 remain frustrated."

In addition to these sample responses, many other views were expressed which had a tenaency to duplicate the remarks presented here. From a program design point of view, this researcher gleaned that managers needed to feel more prepared, they needed to have a better understanding of what was expected of them during this change cycle, they needed to experience the loss, learn how to overcome resistance to change, help employees evaluate contradictory or conflicting information, and basically understand the reason why people react to change the way that they do. Furthermore, they wanted and needed training which focused exclusively around the issues of change. 
The last part of the needs analysis was to get some brief feedback from senior vice presidents about what they expected from the management team during the transition period acquisition. Phone calls were made to five senior vice presidents of PSA. The researcher advised these people that a program was being developed and requested that they give their thoughts, from their point of view, as to what they expected from middle management during this turbulent time. The feedback received centered around expected behaviors dealing with cooperativeness, open mindedness, competence, teamwork and aggressively selling the benefits of the change.

The senior vice president of operations felt that: "Cooperation is critical in times like this. You can agree and cooperate or you can disagree and cooperate. You can't not cooperate. Especially when the change is of such magnitude, you have to have cooperation."

The vice president of inflight services stated: "Along with having an open mind about all that is changing, the employees still must do their job and be competent. It's hard not to presuppose what will or will not happen, but it's a waste of time. I expect my managers to be open minded and competent. They need to focus on doing their jobs."

Feedback received from the vice president of customer services centered around teamwork: "We're all in this together. We have to pull together as a team, working 
together to keep the airline running. Meanwhile, we have to enthusiastically sell the deal. Our employees need to see us supporting this merger, not just supporting but energetically supporting! That will advocate teamwork."

This feedback was integrated into the design of the "Leading in Changing Times" program, particularly since it was an expressed need from the management discussion groups that expectations be presented and discussed.

This needs analysis was extremely beneficial from two perspectives. First, the researcher met her objectives of getting input and feedback about the perceptions of the change to incorporate into the intervention, and second, the process of obtaining the input and feedback itself demonstrated a desire to listen and expressed concern and care about the point of view of PSA's managers.

The feedback, coupled with the basic beliefs previously discussed, established a solid framework from which to design and implement a programmatic process dealing with how to manage and lead in times of change. The Programmatic Process Content

The program entitled "Leading in Changing Times" was a specific action which PSA executives took to help facilitate the change event at PSA. The program included introductory components, eight key subjects and extensive summary remarks and debriefing dialogue. Additionally, each participant was encouraged to build an action plan surrounding the material they had learned during the day. 
In the introduction to the program, the issue of studying change was addressed. In other words, the basic purpose of the program, besides the obvious purpose, to help PSA employees handle the merger better, was to clarify the significance of studying change in the business arena. From a more global perspective, change should be studied for three reasons. First, the magnitude and amount of change that managers experience in their personal and professional lives are overwhelming. The rate at which change influences us is far greater and faster than ever before.

Second, the price tag associated with ineffectively managing change is significant. Loss of productivity is inevitable during transition, and loss of productivity has a price.

Lastly, a key purpose for studying change is so managers can better prepare themselves for change, so that managers can be in a position of choice, not chance. A strategic business philosophy of choice not chance, or proactivity not reactivity, is often more productive for the organization as well as its members.

Then the objectives of the program were reviewed. These objectives reflected both the basic beliefs of the researcher as well as the input from the managers' discussion groups. The objectives were:

1. To realize that managers and leaders must recognize change as a part of how they manage and lead. 
2. To understand that change events are triggered and are therefore, predictable.

3. To identify four natural human resisters to change.

4. To know that change events must be prioritized.

5. To learn how the manager's will react in times of change.

6. To learn skills associated with overcoming resistance to change.

7. To understand what PSA expects from managers in changing times.

8. To review a change implementation planning guide.

As a warm up activity, managers were asked to break into small groups of 4 or 5 members each. A discussion took place which focused on such questions as: "How did you and your employees find out about the merger of USAir and PSA?" "How did your employees react?" "How could this change event been handled more smoothly?" and, "What do you intend to do to ensure that the transition goes wel1?"

Heated discussion typically ensued wherein venting of emotions and frustration came out. The discussions were debriefed and the key points were recorded on flip charts. Having frustrated feelings surface at the beginning of the session helped to diffuse the need to do so all throughout the day. Attention could now be directed more positively 
to the content of the course and the information it provided.

Next, the point was made that oftentimes we view change as something that happens to us or something that is put upon us. This is the kind of change that can leave us feeling helpless or victimized. Change, however, can be viewed from more than just one dimension. Change can be viewed from four dimensions. As indicated in Figure 40 , there are four change quadrants.

Quadrant 1 represents those change events internal to you. You, or someone else, have identified a behavior which you would like to change, for instance, stopping the habit of smoking cigarettes, losing weight, being more positive, improving your coaching skills, making an effort to delegate more, or deciding to become more educated about an important issue.

Quadrant 2 represents those change events that happen externally but impact you. The person has identified something that is changing in one's environment which influences the person. Examples of these types of changes include getting a new boss, your house burns down, you experience a death of a loved one, a good friend moves away to another city, a new community leader is appointed, or your company gets acquired. Quadrant 2 is the most common perspective of change.

Quadrant 3 represents those change events that are internal to others. The person has identified a behavior 


\section{chane:}

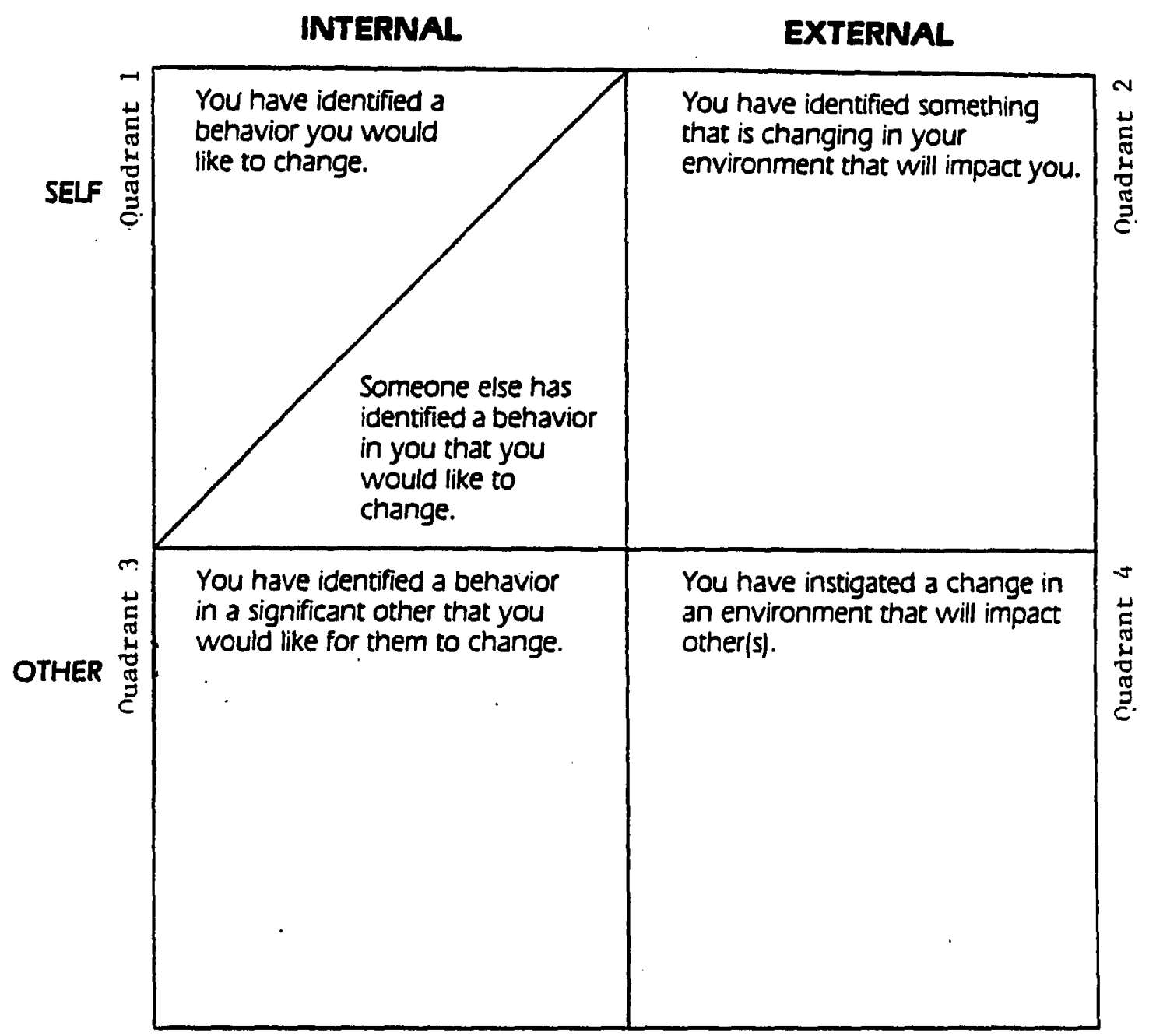

Figure 40. The four change quadrants. 
in a significant other that needs changing. Examples of these types of changes include, helping a child improve study habits, encouraging a spouse to control his temper, assisting a subordinate to develop a new skill, counseling a colleague about his or her writing skills, or supporting employees in the transition phase of a merger or acquisition.

Quadrant 4 represents those change events that occur externally, initiated by you and which have an influence on others. An individual instigates a charge in the environment which impacts others. For instance, you design and implement a new policy or procedure, you initiate a new work flow to improve productivity, you start a remodeling project on your home which impacts your family, you make a decision to cut costs by letting staff members go, or you make a new revenue goal for your saies team.

Not all change occurs from the perspective of Quadrant 2. In fact, every change that happens has a requirement for a multidimensional view.

Participants were then asked to think about the acquisition of PSA by USAir and create a personal, practical application to each quadrant of change (Figure 41). The questions the managers were asked to answer were:

1. Quadrant 1: What two behaviors related to the merger do you want to change? 
INTERNAL

What two behaviors do you want io change?

1.

SELF

苞

What (2) behaviors would you like your significant other to change?

1.

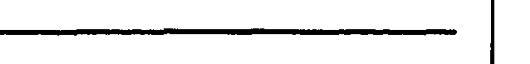

2.
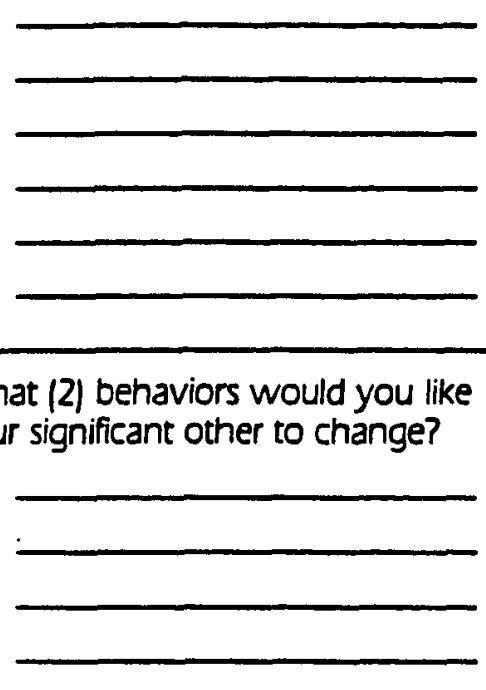

OTHER

2.

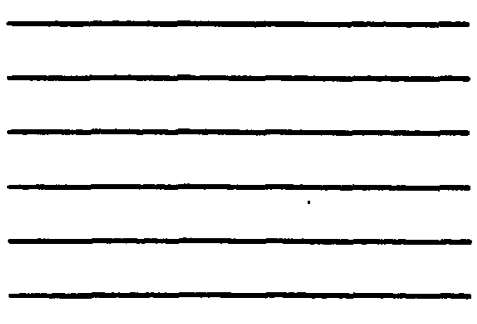

EXTERNAL

What two changes are happening your life/environment that impact you?

1.

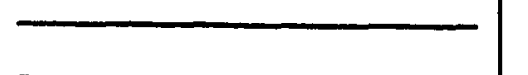

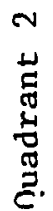

2.

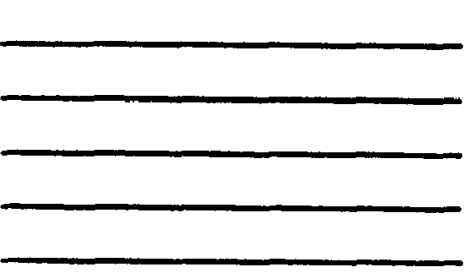

What (2) decisions have you re cently made which impact other(s)?

1.

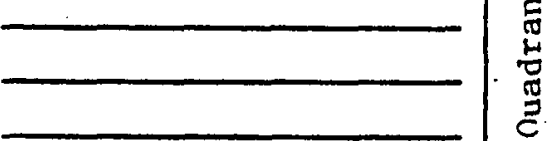

2.

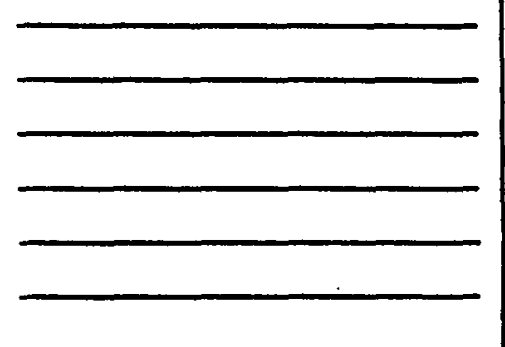

Figure 41. Practical application questions as they relate to the quadrants of change. 
2. Quadrant 2: What two changes are happening in your life/environment that impact you as a result of the merger?

3. Quadrant 3: What behaviors related to the merger would you like a significant other to change?

4. Quadrant 4: What decisions have you recently made concerning the merger which have impacted others? Now that participants had a better understanding of the dimensions of change, the researcher felt it was important that they also understand that leaders must recognize change as a part of how they lead. A discussion was initiated to have the group differentiate between management and leadership. A group list was built with words describing management and another list was built with words describing leadership. This stimulating discussion led to the conclusion that leaders are initiators of change. Leaders tend to operate very easily in Quadrant 4, where initiation is commonplace. This conclusion led to a broader understanding of the role of a change agent and its relationship to leadership.

Typically, change action occurs as a result of some other action that occurred in the internal or external environment. Not all change happens just for the sake of changing. Particularly in the business community, there are so many existing, influencing factors that require an organization to change, to shift or to renew itself. This is an important point to understand so that people do not 
have the tendency to think that someone is "doing change on them or to them." For example, the external environment in the airline industry had an immense impact on the fact that PSA was purchased. The profit picture for the company was dismal, competitive pressures were increasingly strong and even customer needs influenced the purchase of PSA by USAir. Most significantly, the acquisition mania wherein many of the mega carriers were buying up the smaller carriers made PSA an ant in an elephant field. The elephants, because of their vast resources, could simply take a step and crush an ant such as PSA. Smaller carriers were getting strength by becoming parts of the larger giants. Most notable was the acquisition of AirCal by American Airlines. This move was a crucial one in that it left PSA alone in a marketplace consumed by elephants such as American and United airlines. The ability for PSA to continue to compete in an arena were giants existed was very slim. All one would have to do would be to compare the advertising budgets of each of these carriers to realize that PSA could not reach its customer base in the same way that the mega carriers could. Getting a larger market share would be next to impossible for $\mathrm{PSA}$, let alone trying to retain existing market share.

It is valuable to spend time looking at the factors that existed within the external environment so that a more educated vision could be developed as to why this 
change was happening and, in a sense, why it was bound to happen.

Equally important, it is valuable to look at the changes that can take place internally in an organization that can often trigger more change. For instance, factors such as staff people changes, product changes, technological changes and more are quite often triggers that more change is in the wind.

A full analysis and discussion took place as a group where the identification of both external and internal factors were listed which may have had influence on the fact that PSA was ultimately purchased. Examples of factors that were listed under the heading of "External" were changes in government, regulations, competition, economic conditions, laws and more. Examples of factors that were listed under the heading of "Internal" were changes in profit and loss, product, technology, people, pricing and more.

So far, a kind of unfreezing process had taken place in the classroom. The intervention was designed to start out with time for expressing views, venting, acknowledging feelings and simply talking about what was on the minds of the managers. This unfreezing was structured to focus on building an understanding of the merger and about the subject of organizational change itself.

The next segment of the program delved into a description and discussion of some of the natural human 
resisters to change. Two of these ideas will now be presented as examples of human resisters to change, although several were actually presented in the intervention.

First, an idea was introduced called "scotoma." Scotoma is a term used in the field of medicine, specifically in the area of optometry and ophthalmology. The word literally means a dimness of vision or a blind or dark spot in the visual field. Using this idea metaphorically, the researcher discussed whether or not people can have psychological scotomas about change. Typically, a very stimulating discussion resulted around this metaphor. In all cases the participants decided that people tend to want to be attached to that which is familiar to them as opposed to that which is not familiar to them. As soon as something unfamiliar is introduced, in this case USAir, scotoma is likely to occur. It's as if scotoma were a natural human resister to accepting change and something that prevents us from accepting change. Various people in the class openly gave examples of personal scotomas and usually the group members found themselves laughing and smiling at the prevalence of humans to have scotoma. It allowed managers to see a potential reason why we sometimes are not quick to be accepting of change. Our own human scotoma, our own desire to want to be attached to the familiar, our own way of myopically seeing the world sets us up to be resisters of change. That point alone was useful to the group 
members because having recognized the idea of scotoma, it allowed them to now move on as well as to better assist their staff members if they too were feeling any scotoma. Another idea which was presented as a natural resister to change was called "protectors." The idea was that people have a tendency to want to protect themselves when they get in situations that are unfamiliar or new to them. Protectors are really ways in which we tend to camouflage our perceived weaknesses.

One way that we can protect ourselves is by compensating. Compensation is basically an idea that suggests that if a person is not skilled in one area or is not familiar with an area, that person may tend to compensate for that weakness by excelling in another area. An example of compensation might be if a person is not skilled at statistics, he or she may tend to excel in subjects pertaining to the arts. Another example might be that if a person a not familiar with USAir as a company, he or she may tend to gravitate strongly to PSA. Compensation is a way that we can protect ourselves from having to change.

Another protector that people may exhibit is called displacement. If a person is unfamiliar or uncomfortable with something, or even uncertain about something, he or she may want to give it to someone else, or displace it, so he or she does not have to own it; thus, protecting the person from accepting whatever it is that is making 
that person feel uncertain. An example of displacement might be if someone gets lost on the road while trying to get to a place that is new and unfamiliar, he or she may take it out on the person he or she is with. The person may displace that feeling so as to be protected. Another example might be that if a person is in a state of high ambiguity about the status of his or her job as a result of a merger or acquisition, he or she may tend to take it out on, or displace it to, his or her significant other.

The ideas of compensation and displacement as examples of protectors were discussed in the workshop. Participants were extremely open about their own examples of when and how they compensated or displaced in order to protect themselves. A great deal of discussion, of course, centered around the merger. The atmosphere at this point in time in the seminar was always open, fun, and light; yet awareness was shaping in the minds of the managers about the potential, natural, human resisters to change. After managers developed an understanding about the natural human resisters to change, the program moved to talking about the value of prioritizing change events. We all experience so many changes in our lives, it is important that we view those changes in some priority fashion.

In this section of the program, some classic time management ideas were presented and discussed, after which participants had the opportunity to break into a short 
workshop where they identified, prioritized and developed an action plan on many of the specific changes that were happening in the merger process.

After the small group workshops and after participants returned from lunch, it was time to delve into the subject of how people tend to react when change is announced.

The main idea of this section of the seminar was to create an understanding that most people do not just accept change and begin their day as if the past never happened. Usually, people have a need to end, or establish closure, before they are able to move on to other things. This closure is a time of mourning that was brought out by one manager in the needs analysis group discussions. It is a time to deal with the loss of what was. During this time of ending, people may have a need to rediscover while simultaneously adjusting to the reality that that which was familiar will no longer be. This time of ending is particularly important in cases where change is extreme such as in the death in the family, a divorce or a merger or acquisition.

Next, before people can begin, they must have some time to make a transition. Since a feeling of disorientation is likely to exist, it is crucial to allow time for making a transition out of the old and into the new. Disorientation can be great during a transition since the old is gone but the new is not yet here. 
Lastly, a beginning can evolve. This is the time where receptivity tends to be high and testing of the waters takes place. Then, and usually only then, can acceptance of the change really happen.

After these ideas were presented, another open discussion was stimulated where individuals began to give examples of situations in which they had to first end, then make a transition before they could begin something else. These personal examples were the practical applications that are often necessary in order to have learning and understanding take place. Examples that were given from participants also included instances where their employees had difficulty with these stages and they had expected them to simply begin, without time or attention to the ending and the transition.

The discussion in all cases brought out two significant points. First, managers have a need to evolve through each of these phases. They have a requirement to experience the loss, make a transition out of the old and into the new, and then begin with an attitude of acceptance and ownership. Second, managers discovered that they had been impatient with their employees when they did not simply begin anew when changes were announced. They now realized that that attitude was not acceptable. To have an expectation that employees simply accept everything that happens, including a merger of their company by USAir, is not at all realistic. What is 
realistic is to work together to evolve through the phases of accepting change which include time to end and time to make a transition.

The discussion continued when managers were asked to break into small groups and develop a list of signals or behaviors that were likely to be exhibited when a person is going through the ending phase, the transition phase and the beginning phases.

During a debriefing discussion of results from the small groups, typical signals and behaviors that managers thought people would manifest were behaviors such as anger, tardiness, lack of interest, withdrawal, anxious curiosity, and more. After this discussion, the people were asked to regroup in the same small groups to identify what responses would be most appropriate for each of the signals and behaviors exhibited in each phase; ending, transition and beginning.

Responses tended to be specific to each phase and included remarks such as listening and clarifying, informing, supporting, encouraging, getting others involved, and more.

The researcher believed that this section of the intervention was important in that it exclusively offered ideas pertaining to how people can react to change, what that reaction is likely to look like, and, most importantly, what a manager could do to help facilitate staff members' responses to the change. 
Now that some conclusions could be drawn as to how people often react to change, the next logical subject matter of the program was overcoming resistance to change. In this segment, some very specific ideas were presented concerning techniques to structure an interaction with an individual or a small group to explain a change in a way that minimizes resistance.

In a classic systems organic way, five steps were described as a tactical approach to a change discussion. Additionally, a planning guide of questions was presented as a tool to use before one engaged in the actual interaction.

To communicate a planned change, one should first understand what specifically will change and why. This information is needed so a manager can make a meaningful analysis of the change prior to it being communicated. Some suggested questions to trigger a good analysis are:

1. What are the problems that this change is designed to solve?

2. What will exactly change?

3. Specifically, how will people be affected by this change?

4. What questions or objections might people have about this change?

5. How will you as a manager respond to those questions and objections?

In small groups, the group came up with answers to 
these analysis questions as they pertained to the merger of PSA and USAir.

Next, the steps to follow for the communication were introduced as a possible structure or road map to follow.

1. Describe why the change is needed and the specific changes that will be required.

2. Ask for reactions from the person or the group to determine where they are at and what is on their minds.

3. Clear up any misunderstandings or questions and acknowledge any objections that were made.

4. Ask for any ideas on how to make the change go as smoothly as possible.

5. Ask for the support and commitment from the person or the group for the change effort.

6. Follow through by monitoring the plan and reinforcing the progress.

When a change is announced, people have a tendency to ask themselves: "How does this affect me?" If the manager addresses this concern with specific, honest information, it can help to reduce uncertainty and mistrust. People tend to be more receptive to change when they understand the logical reasons and the thinking behind it. This also starts people thinking about what they have to do to make the change successful.

Explaining a change and its impact is not just a show and tell exercise. Because change temporarily disrupts and complicates things, people need access to the right 
information if they are to respond positively to change. They need an opportunity to ask questions and get answers, not just be talked at. The researcher suggested to the managers that when they ask for reactions to a change, they should create an atmosphere of openness. By listening to what employees have to say, the manager can help them feel more involved in the change, and find out about any concerns or misunderstandings. In doing this, the manager communicates that airing concerns is acceptable. Even if nothing new surfaces, the fact that the manager really listened to people's thoughts and feelings goes a long way to building trust. Listening can make the road to change, if not free of bumps, at least smoother than it might be otherwise.

Thorough understanding requires an exchange of feelings and ideas. People's concerns must be actively recognized and directly answered. If they are not and people do not have the right information, they cannot do their best even when they want to be helpful. Worse, people sometimes prepare themselves to resist a change because they lack information and anticipate the worst. They need enough of the right information to be able to work constructively with the change.

It is vital to get people thinking and talking about what they can do to make the change work. Once managers have discussed their views and all the rationale behind the change, a bias for action will help avoid unproductive 
deliberation. Also, because the best ideas often are held by the employees who actually do the work on the front line, many a required change may be saved from sure failure by front line leaders who are willing to tap and use their employees' ideas and suggestions.

Effective management is a give and take relationship. Preparing people to work through change is no exception. If a manager has carefully walked through the change requirements and thoughtfully responded to the employees' needs, the manager will be more prepared to offer support and commitment. The key is to ask for it, not demand it or assume the employees will go along because they have no choice. Asking for support can establish a binding understanding between the leader and the group, even when people are not one hundred percent in agreement with a change.

The job is not over once the manager has introduced a change and made some plans. Change has a way of changing along the way, particularly if it is not monitored and reinforced. The manager's ongoing attention needs to be directed at insuring that everything is progressing as planned, or that appropriate adjustments to the plan are being made as required.

The people involved in the change need personal attention as well. Their tensions and fears may increase as the change process moves toward completion. If not caught early, this can create new obstacles to achieving 
successful change implementations.

This segment of the program was summarized by suggesting that it is not as hard to manage when things are stable, when people are not anxious or hesitant, and when there is not much as risk. However, when a manager or leader is faced with change, turbulence, uncertainty and pressures that can push the organization to new heights of accomplishment and prosperity or to all time lows of inefficiency and loss, attention needs to be paid to how we overcome resistance to change.

Several other ideas were discussed in relation to how to overcome resistance to change. The idea of unfreezing was introduced and usually lengthy conversations surfaced from participants as to their thinking on that concept. Additionally, some remarks about how to resolve conflict were reviewed. Often when a manager experiences the need to overcome resistance to change, he or she is vulnerable to emerging conflict. Being an effective conflict resolver is another critical skill that can be extremely useful to the manager as change is presented and discussed.

In order to get a sense of what the senior management of PSA expected of its management team during this acquisition of PSA by USAir, the construct of expectations was introduced. Some discussion began around what the managers expected of their front line employees as the change progressed. Then, the discussion shifted to what 
the managers thought that senior management expected of them. A list of ideas was formulated in each session and, at all times, included in the list were the items mentioned from senior management as described early in the needs analysis. Cooperation, open mindedness, flexibility, competence, teamwork, and selling the change were always included in the list developed by the managers. A meaningful discussion typically followed as to whether or not these expectations were reasonable. In most cases the group members felt that they were.

Each group designed its own change implementation guide. One that stood out as being particularly interesting was one that was developed around the acronym PROACTIVE.

Managers felt that first people need to be prepared for the change and that high activity should take place around getting prepared. Then the manager should rally with a vision. What are all of the exciting possibilities that this change will make reality? Operating as a team is extremely beneficial as is acknowledging the uncertainty that some people may be feeling. Communicating what is happening at every available and appropriate moment will build trust and telling all you can from an honest perspective is essential to a smooth change event. Involving others to the extent that that is possible is important to gaining commitment, and visibility of the manager to answer questions also gains 
commitment.. Lastly, the emphasis of caring can not be overlooked in a turbulent time such as a merger or acquisition.

The acronym reads:

P Prepare people

R Rally with a vision

O Operate as a team

A Acknowledge uncertainty

C Communicate what is happening

T Tell all you can, be honest

I Involve others

V Visibility is vital

E Emphasize caring

This particular summary that one group developed was then shared in every other session because this researcher thought that it was an excellent conclusion for a long and substantive day.

During the debriefing sessions, the objectives of the intervention were once again reviewed to ensure that all the planned material had been covered. Then, each manager expressed his or her thoughts about what was learned and what would be done differently as a result of the program. An example of a typical closing remark was: "I believe that I have such an advantage now because we have taken the time today to talk about the change that is happening. I have learned so much that I can apply this material not only to the PSA-USAir merger, but to any other change that 
may happen in the future. The part that was most meaningful to me was the fact that the company cared enough to allow us to attend this program and the fact that I now feel equipped with information, understanding, and knowledge about the complex subject of change in organizations."

Another remark that was representative of the reaction to the program was: "This is information that I can use. I have learned it here today, and I can go out and use it tomorrow. The fact that there was so much interaction, discussion and practical application made this program especially helpful to me. I have changed as a result of attending this course on change."

Another response was: "The fact that this seminar took place has an impact on this merger. We will now be able to more fully and consciously facilitate the change while simultaneously getting to the end result; as opposed to just getting to the end result without facilitating the change in the process. Because of our facilitation of the change, our employees will be better managed and, therefore, more productive."

One last response that was quite interesting for this researcher was the following: "It seems as if this course is a part of something bigger that PSA is trying to do to help all of us make the transition more smoothly into USAir. I think that the level of communication about what is happening has been stellar, and now with this program 
being available to all PSA's management, it seems like many efforts are taking place to help us. It's almost as if this is only one part of a change implementation strategy designed from a leadership which intentionally and strategically is leading in changing times."

The programmatic process that was initiated at PSA was based on some basic beliefs that this researcher held. After the needs analysis was conducted, the program content was developed. The program was instrumental in assisting PSA managers to maintain the productivity levels required to run the airline.

This third leg of the overall five legged change strategy was both systems organic and personal therapeutic in nature. The lens that was used predominantly came from these two models of change.

By using the "Leading in Changing Times" program, the managers clearly understood that multiple lenses of viewing the merger were created. This sudden jolt of USAir purchasing PSA required a higher level thinking process to ensure acceptance and understanding. Multiple views of the change assisted the managers in their higher level thinking.

\section{The Impacting Leader Actions}

The fourth category of the overall change strategy deals with the actions that were taken by President and Chief Operating officer Russell Ray. The actions that were taken during the specific time of this qualitative 
case study were the ones that will be described in the section of this chapter.

This segment will first look at Russell Ray as President, followed by a description of his commitment to the development and execution of the change strategy, and then, the specific actions he took to help facilitate the change event. Each of these areas will be linked to the applicable models of change as warranted.

A Look at Russell Ray

In the summer of 1985, Russell Ray joined Pacific Southwest Airlines as President and Chief Operating Officer reporting to Paul Barkley, Chief Executive Officer of PSA. Previous to his position at PSA, Ray spent the majority of his career with Eastern Airlines, headquartered in Miami, Florida. At Eastern, Ray was involved in nearly every aspect of airline operations during his career. As a senior executive there, reporting to Frank Borman, Ray had an array of experiences from a variety of different disciplines including marketing, station operations, inflight service and flight operations. Previous to his work at Eastern Airlines, Ray also spent time at McDonnell Douglas Corporation and in the United States Navy. He was a proven manager with an extensive background in aviation and airline operations. Along with a full resume of skill, experience, education and background, Ray was highly charismatic. He had a decisive style which advocated hard work, long 
hours, focus, direction setting, goal setting and achievement and bottom line results. Simultaneously, Ray modeled team work, fair play and above all, communication.

Four significant examples that best describe Russell Ray will now be discussed. These examples will help to paint a picture of the way in which this man tended to operate.

First, Ray deliberately created stories so that they could be told within the organization. He specifically believed that stories were symbols of how a culture could be built within a company. As such, during the first week of Ray's employment with PSA, he started a ritual of going out onto the airport ramp during the very early hours of the morning to talk with the aircraft mechanics. He would walk around, introduce himself, shake hands, and ask questions of this particular work group. This visibility was atypical at PSA and so the stories began of how the President had morning coffee out on the ramp instead of in his plush office. On one occasion employees told the story that Ray even handed out baseball tickets to mechanics while saying thanks for getting the aircraft prepared to ensure the on time performance of the airline. Another story that was lived and created by Russell Ray was when he actually helped sky caps tag passenger bags at the San Diego, California airport. This particular event was even covered by the press and ended up being spread throughout the organization as a symbol of 
doing what it takes to make the customers happy.

Russell Ray used his charisma to his advantage to engage organizational stories. Frequent tales were told of Ray popping into a particular office, crew lounge or break room when it was least expected. He would shake hands, ask questions, give updates on issues of particular importance at that time and then move on.

From a cultural symbolic perspective, Russell Ray used these types of events as vehicles for conveying meaning. Those aspects of an organization that its members use to reveal or make comprehensible the unconscious feelings, images, and values that are inherent in that organization are called organizational symbolism. Ray used planned sets of activities such as the ones exemplified, to consolidate forms of cultural expression. Second, Ray was compelled to develop a specific focus and direction for the organization. As such, he and his direct reports spent a great deal of time and energy trying to determine what rally points would exist for the organization. An outside consultant was contracted and came in to spend several days with senior managers as a group to agree upon a framework that would define the focus for the upcoming year. In essence, a mission statement was being developed.

Laboriously, and only after several months of discussions with employees, focus groups, and more discussions among senior managers, three "rally 
points" were created that became the mission of the organization. They were:

1. Generate superior return on investment each year.

2. Operate on time.

3. Dominate our markets.

A communications blitz took place after these points were established and an entire plan was put in place in order to ensure that the points were remembered and realized by all employees of PSA. Clarity and focus within the company had finally taken place.

Third, Russell Ray had the belief that internal communication was paramount to the organization. Accordingly, a comprehensive communications plan was developed, communicated and implemented. Figure 42 reflects the belief in internal communications as the brochure highlighting PSA's communication strategy was exemplified.

In the cover letter to all employees, Russell Ray communicated this focus:

The commitment to open communication is a top priority with PSA's management team. In the past, Employee Forums, newsletters, advisory groups, and several other techniques have been used to help keep the lines of communications open. We have since added, deleted, revised, and fine-tuned some of those elements to make communications more efficient and 
Oommunication is what transforms a promise into reality. It is the words that speak boldly of our intentions and the actions which speak louder than our words. Communication is the power of change. It is the daily triumph of integrity over skepticism."

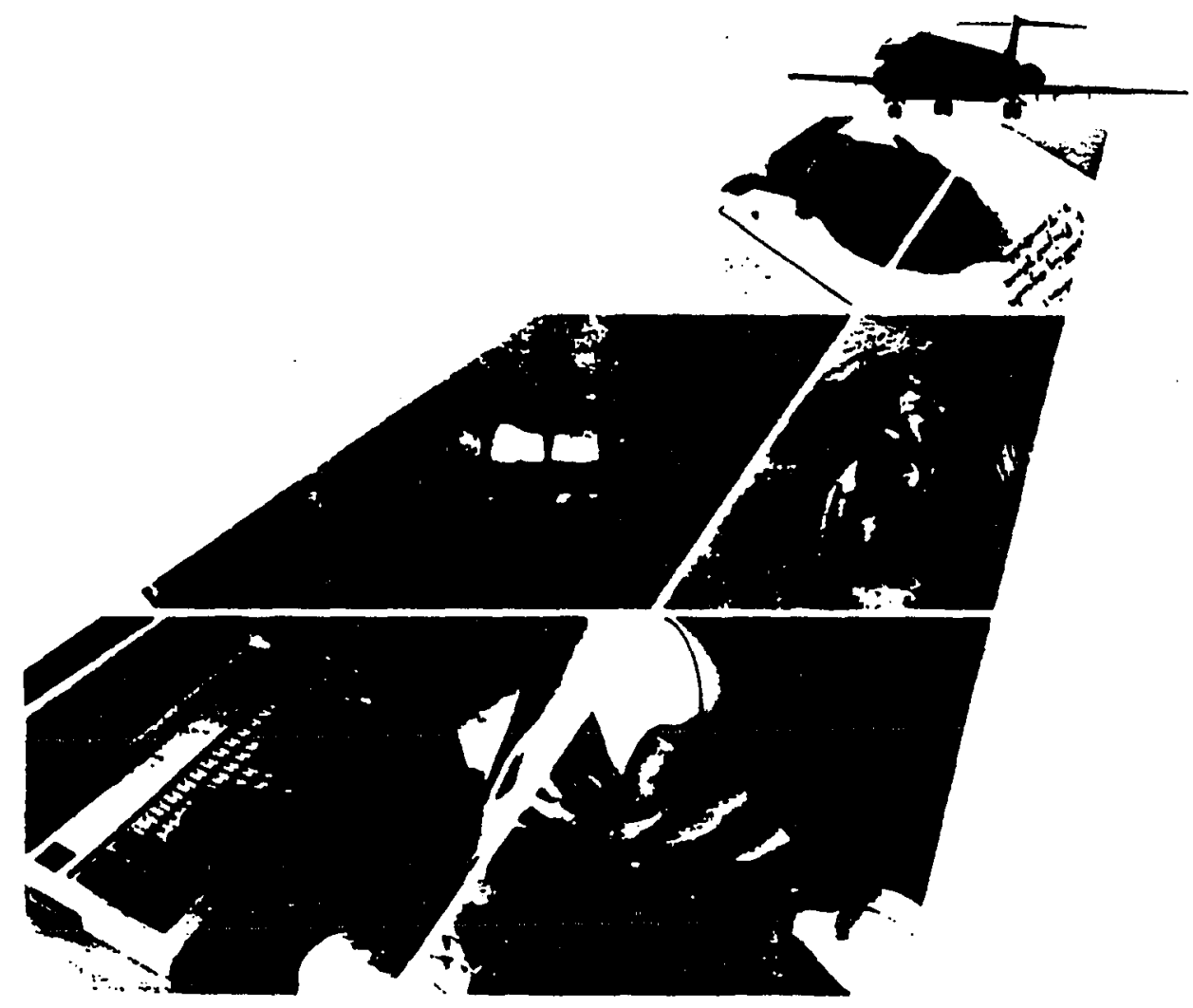

PSA'S COMMUNICATION COMMITMENT

Figure 42. Cover of PSA's communication strategy brochure. 
effective. - We know you want company information on a regular basis; you see the importance of meeting with management; and you want updates from your own supervisors. In other words, you want to hear accurate information directly from management and not through the grapevine or on the evening news. We agree!

The communications brochure described the specific communication vehicles which PSA would inaugurate and the purpose of each:

1. PSA New Update: This publication capsulized both PSA news and external news of interest to employees using an unbiased, straight news approach. The content included personnel changes, news about the airline industry, competition, and relevant national new items.

2. Perspectives from the President: PSA President Russell Ray relayed new messages editorially to all PSA employees on pertinent topics.

3. Perspectives from the Chairman: Paul Barkley, PSA's chairman of the board and chief executive officer, provided editorial information to employees regarding capital asset purchases, long term goals and broad issues relating to PSA and PSA, Inc.

4. PSA Progress: This publication conveyed information and educational issues of interest to all PSA employees. Generally, topics included PSA Profit sharing and Stock Plan, the $401(\mathrm{k})$ Plan, financial conditions, and 
information. from the Employee Forums. One member of each employee group served on the Progress Editorial Advisory Board to provide input before publication.

5. Management Forum: Paul Barkley, Russell Ray and executives officers met with the managers of all departments twice each year to address important issues facing the company.

6. Employee Owner Forums: These meeting enhanced two way communication between corporate officers and all employees on a variety of issues concerning PSA. They were conducted twice each year.

7 PSA Training and Education: This activity provided the opportunity for employee to enhance and develop skills. Over 400 programs were offered each year.

8. Employee Recognition Lunches: These monthly luncheons recognized PSA's peak performers and provided a direct communications link between Russell Ray, corporate officers, and employees to informally discuss current issues affecting the airline.

9. Departmental Advisory Groups: These groups provided an opportunity for employees and managers to address specific problems and recommend solutions within each department of the company. It was employee ownership in action.

10. PSA News Hotline: This was a one minute news update provided to employees. The Hotline was handy for mobile employees such as flight attendants and pilots. 
11. Telephone Blitz: If urgent news of interest to all PSA employees was about to break prior to the release of other communication vehicles, each department was phoned with the news.

12. Special Videos: Employee informational video programs were distributed to provide educational support and special messages on an as needed basis.

13. Employee Representative Briefings: PSA Vice Presidents and employee representatives, including key union leaders, met together to review PSA's financial performance on a quarterly basis.

14. Shareholders' Report: These brochures released financial information to stockholders and employees regarding the state of the company.

The investigator reviewed the elements contained in the communication plan of PSA to highlight the view that Russell Ray, who initiated the design of the plan, was indeed an advocate of honest and consistent communication to the employees of PSA.

Fourth, Russell Ray, along with his senior management team, established the corporate goals for the organization. These goals were crisp, concise and very clear. They were:

1. Strengthen PSA's dominance in the traditional California markets.

2. Increase PSA's presence in higher yield interstate markets. 
3. Utilize the BAe 146 aircraft's unique characteristics in size, unit cost, and noise control.

4. Hold PSA's presence in low fare markets until profitable expansion could be achieved.

5. Flow new traffic into the PSA system via the Los Angeles and San Francisco hubs.

6. Maximize station productivity by selective expansion to underserved and new cities, tying them together.

7. Improve system productivity by increasing aircraft utilization, improving flight length, pursuing off peak charters and cargo revenues.

In just a very short period of time, Russell Ray managed to express stories in a way that created symbolism for the company, create a mission which employees could rally around, design an aggressive communications plan which set the tone toward a new way of doing business at PSA and establish corporate goals.

These four examples are illustrations which describe the kind of emphasis that Russell Ray wanted to take during his time as President of PSA. The initiatives describe the kind of values that were held by Ray as well. Since each of these actions were initiated by President Ray in a highly charismatic and persuasive style, they tend to paint a picture of the man as they represent the activities that he held in high esteem. They also reflect his belief system. 
Development. and Execution of the Change Strategy

In early December of 1986, just after it was announced that PSA and USAir had entered into the merger agreement, a meeting was called for the purpose of addressing a change strategy. The participants of the meeting were from line operations and staff functions and included this researcher who was then Staff Vice President of Human Resource Development. Ray's objective was communicated as follows: "It's too early to have answers to all of the questions that are now rampant, but it is not too early to come up with a plan as to how we will communicate the answers once we have them. Our employees need to be kept up-to-date. In order to keep the airline running, we should have a thorough change strategy that includes a lot of communication to employees so that everyone knows what is going on. It's a difficult time for us and our employees. The only way to help ease the turmoil will be to consistently and accurately communicate. We must pay attention to the care and feeding of our employees."

In the days that followed that meeting, a number of senior managers spent a lot of time designing a strategy that would:

1. Constantly and consistently inform all employees of the news of the merger.

2. Continuously educate employees about all facets of the acquisition. 
3. Assist employees to be well read and knowledgeable about the change.

4. Provide practical tools to the managers on how specifically to manage through the change.

5. Ensure that senior managers were visible to employees as well as supportive.

The managers made a deliberate attempt to ensure that employees had the opportunity to view the change event from as many different perspectives as possible. The managers consciously thought and believed that if multiple views of the change could be presented and facilitated as part of the overall change strategy, then more understanding and less resistance to the change among employees would result. The managers further thought and believed that the creation of multiple views could be stimulated through a deliberate change strategy as opposed to assuming that employees themselves would naturally create their own multiple views. In essence, multiple views could happen by design, instead of by accident, if the change strategy incorporated the construct that multiple views were more valuable than single views.

Most importantly, Russell Ray and the entire group that worked on the change plan operated from the basic notion that PSA employees needed to be attended to. This basic notion stemmed from a genuine concern and care about the employee population as human beings. The more smoothly the change could occur, the more likely it 
was that the employees would be free of the excessive stresses and pressures that change and uncertainty often cause.

So, Russell Ray had a deep commitment, both from a personal as well as a professional level, toward the development and execution of a comprehensive and high caliber change strategy. As such, this commitment permeated the organization as an expression of care and concern. That commitment alone was a significant element in the success of the change during this slice of time in which this case study took place. Actions Taken to Facilitate the Change

The two most significant actions that were taken by Russell Ray which helped to facilitate the change and which had an impact were a special video taped message to all employees and a series of management meetings where other messages were delivered. Both of these actions originated from Ray's consistent and intense belief that communication was paramount.

First, the video taped message will be described, followed by critical points made from management meetings. Shortly after the announcement was made that USAir and PSA had entered into a merger agreement in early December of 1986, and before the year ended, Ray met with this researcher to express his desire to send a message to all of the employees of PSA. He indicated that he was especially concerned that the news of the potential 
acquisition. could cause some employees to be disturbed over the holidays. He was genuinely concerned about that. Equally important, Ray expressed his concern that all the news would create an unsettled feeling among employees and he feared that productivity would suffer. He wanted the airline to run in a highly efficient and productive fashion, not only over the peak holiday travel period, but on into the following year. There was also an expression made that captured his sense of sadness that the PSA era may be ending. He had started his career with PSA less than two years before the merger announcement and he would be unable to bring forth the kind of expansion and profitability that he had hoped for. The dream of remaining an independent carrier had vanished.

Ray wanted to be video taped the next day so that his message would get to PSA employees quickly and before the holidays. He indicated that no one would write his script, that he would prepare his remarks that night, and that he would simply speak his thoughts to the camera the following day.

The message was taped in Ray's office as he sat at his desk and it began as follows:

Well, now is a good time to communicate with the employees of PSA. We're into the holiday season, and obviously the events of the past week or so have caused a need for the sharing of at least my thoughts. I guess the only thing that's missing is 
the roaring fire behind me for this little chat.

Ray used an analogy relating his remarks to those of the fireside chats that have been associated with the President of the United States.

Next, Ray spoke about the state of the airline, reporting that it would not be likely that profit sharing would occur for the year 1986 .

1986 has almost ended. It's been an interesting year. They all have been since your careers started. This particular year started with a little bit of momentum. That is to say we came into 1986 out of a fare war in 1985, causing us losses at the end of 1985 and the beginning of 1986. But then the momentum picked up and a great deal of credit goes to each of you for the past marvelous summer where we set all kinds of records, ending with that momentous occasion in July and August when we started to board a million passengers per month. Sad to say, right after Labor Day the traffic started to subside, and it continues to be soft even though the prospect of the next two weeks remains strong and I'm optimistic about that. But there's a strong unlikelihood that we'Il make profits for 1986 , I'm sorry to report. I don't think we'll have losses but it will be close to break even, and that will have an effect on profit sharing, as you know.

The bad news had been communicated. The fact that no 
profit sharing was likely was a disappointing factor to all the PSA employees who have previously given up $15 \%$ of their pay for $15 \%$ of the company.

Next, the news of the merger agreement had to be addressed, which at this point in time was also bad news for the majority of PSA employees who were still in shock about the announcement. Ray went on to deliver his message:

As for the situation of the past week... I entered my employment with PSA, as you know, in the middle of last year with strong thoughts about the dream I had of independence for us. And although I maintained those thoughts, and so did my fellow managers, throughout this past summer and into the fall, those dreams of independence became farther and farther away as the mergers took place in our area of the market. Delta and Western being one, and culminating on that day four or five weeks ago when American Airlines announced the acquisition of Air Cal; all but shattering PSA's hopes for independence. And on that day, the telephones began to ring, and all I can say about that is we weren't doing the dialing. Ray began to use emotional language during this part of his message through the use of words such as independence, dream and shattered. That emotionalism was being picked up in the tone of Ray's voice during the video tape as well. This emotional description set the 
stage for the next segment of his speech when a tendency toward the cultural symbolic tone prevailed.

And that put us into an interesting position because what you know, and what the consumer knows and what the other airlines in the country knew and still know, is that there's a treasure out here on the west coast called PSA. A treasure of 38 years, a treasure of customer loyalty, a treasure in its people and a treasure in its smile. I look back on the 18 months I had with you, and I could say to you and say to a customer that PSA has more personality than any company in the United States. And those treasures and that personality is not lost on our competition. The best way to appeal to the hearts of any PSA employee was to capitalize on the symbolic PSA smile. To allude to the fact that PSA's smile was a treasure on the west coast and treat it as if it was suddenly going away pulled at the heart strings of many PSA employees.

The next part of the message dealt with expressing a vote of confidence in USAir:

USAir has bought a business. It has bought a business of people and machines . . and a reputation on the west coast. This move has tremendous value to you, because the airline that we are joining has financial strength. It has a track record of years of profitability and the ability to grow in the years ahead with all the prospects of job 
security that go with it. It brings to the west coast the synergies of the east. It reduces for you the likelihood of personnel reductions. A track record at USAir of very generous wages and benefits, and to each of us, to you, a windfall in terms of your stock at PSA, when you consider that just 4 months ago we created a public market for the PSA stock at $\$ 7$, and today the price is $\$ 17$. This was the hard part for PSA employees to swallow. Even though many employees recognized that rationally the USAir merger would be good, they had difficulty dealing with the emotional side of the merger that the "treasure" that they had helped create and build would be drowned. However, the consequences of USAir not being in the picture were significant. Russell Ray continued:

The alternatives to the USAir merger are not happy ones. As I mentioned just a minute ago the telephones that were ringing came from all kinds of people in the country, some of whom you've read about and perhaps would rather not want to be associated with.

This statement hinted at the fact that Frank Lorenzo of Texas Air Corporation had been one of the people interested in taking over PSA. Lorenzo's reputation in the industry was not one that tended to focus on the human element. In fact, his reputation was that he was a union buster and a wage and salary slasher. 
Russell Ray continued his message in a way that once again tended to focus of the cultural symbolic factors. I can pledge to you that in the weeks and months ahead that you are going to have accurate, timely information that will affect you individually. And you can count on that accuracy because you need to know the truth for your own welfare and for your own peace of mind. As for me, I'm intending to eat, drink, sleep, think PSA every minute. I'm committed to that, and I've been committed to that since I walked in here in August of last year. I intend to run it harder and more aggressively than we ever have before, given the fact that we have 2,000 more employees than we had two years ago and we're half again as big.

The use of words such as pledge, truth, welfare, peace of mind, and committed once again bring out symbolic expression. Ray concluded his remarks.

I'm committed. And when that day come, I'm committed to the prospect that this airline will be as good as it was, if not better than it was the day the acquisition was announced. And all I can do is ask from you that same commitment to excellence. That same degree of enthusiasm that put the PSA personality in front of everyone else. The retention of customer confidence is so important. You know, somehow, I believe that whether it be in the hearts 
of our.employees, or on the minds of our customers, or on the noses of our airplanes, there will always be a smile.

Again the word committed was used, along with excellence, enthusiasm, PSA personality, confidence, hearts, and smile. Ending the message with the cultural symbolic tie to the PSA smile gave the message a very dramatic point of view for many PSA employees.

Russell Ray's message was an extremely critical element in the communications strategy of PSA after the announcement was made that PSA had been acquired. The complete transcription of this message shows the reader that Ray was deeply attached to PSA, even though his length of time employed with the carrier was less than two years. This deep attachment was also felt by many PSA employees and was the reason why the emotions were so high about the fact that PSA would dissolve. The organization lived in its symbols, stories, rituals, myths and, in its smile.

The manner in which this particular communication addressed the cultural symbolic aspects of the change event is evidenced by the content, style and language used by Russell Ray in this extremely important and highly visible video taped message. The fact that Ray took action in a way that produced a video taped communication is also illustrative of his strong belief and practice in communicating with the employees. 
Shortly after the announcement was made that USAir and PSA had entered into a merger agreement in early December of 1986, Ray initiated a series of meetings with his key management team to discuss the progress of the acquisition exclusively. Furthermore, these meetings would strengthen the communication that Ray felt was so essential during times when ambiguity was so high. of particular interest were the themes that were developed during these meetings. As reflected from this researcher's field notes, two predominant trends or areas of emphasis emerged from the perspective that Ray took in the meetings.

Over the six month period, Ray held nine such meetings. In attendance were his officer team; inclusive of this researcher. Typically the meetings followed a similar agenda. The operation of the airline was usually discussed in terms of schedule reliability, weather, on time performance and so on. Then, a brief update was usually given as to the status of the merger including a review of key open issues that were taking place as a result of the labor negotiations, plans for integrating the two carriers, a request list for materials that USAir needed to properly review the operation and any other significant points regarding USAir in general. Iast, a discussion usually began around some principle that was introduced by Russell Ray. It is this area that is of particular interest because it reflects the thinking of 
Ray and his.cabinet during the change cycle.

The first theme or area of emphasis that came out of the meetings was symbols to the customer. Ray had a deep concern during this time of transition that PSA not lose the confidence of our customer base. Because turbulent times were beginning and were likely to continue for awhile, he wanted PSA customers to know that they could continue to rely on the airline for their transportation needs. As such, Ray began discussions around the following idea: "Just because we are going through some uncertain times, it does not mean that our customers will have go through uncertain times. All of our customers need to continue to have confidence in PSA. I suggest that we create some symbols to emphasize this as we move through the next several months. Greater attention is going to need to be paid to ensure customer loyalty. This type of transition is the kind of thing that could substantially influence our passenger loads. We all have to be aware of that. Particularly our ground handling personnel, our inflight personnel and our reservations personnel. We need to come up with ideas on how best to maintain customer confidence."

As a result of these meetings, several activities to develop customer confidence were, in essence, blitzed throughout the company.

The first example of an action taken related to all of the ways in which the PSA smile could be capitalized 
on. Inflight employees were given buttons to wear as symbols of the change being an advantage to the customer. These buttons simply said, "Our smiles are getting bigger." Announcements were made over the public address system in the aircraft indicating that PSA and USAir were teaming up and that the PSA smile was spreading to the east. Inflight napkins were printed which expressed the growing smile idea. Even gate agents eventually wore buttons and made similar announcements to customers.

Stories were told during these meetings with Russell Ray about specific customers who had written or called saying that they were shocked about the PSA smile possibly going away. One customer had evidently called in and said that to take PSA out of California was like taking Mickey Mouse out of Disneyland. This story became one that was told over and over again in the halls, offices, break rooms, and crew lounges. In fact, there was a kind of -uprising that emerged about preserving the PSA smile.

Customers who were loyal to PSA were concerned about whether USAir could measure up to the standards they had come to enjoy as frequent PSA flyers. In the meeting in late January of 1987, Ray said: "Our customers for now must believe that the PSA smile is not going to vanish. If anything it's just going to get bigger and better. Somehow customers have a tendency to equate their confidence level in the organization with the symbol that they identify with, and that's the smile on the nose of 
our aircraft. Our customers identify with the PSA smile." The next radio and television advertising spots for PSA captured the idea that PSA and USAir had teamed up and that the smile was going coast to coast. The symbol of retaining customer confidence had landed in the smile.

In another meeting with Ray and his officer team, he expanded on the idea that a smooth operating airline, one that was on time, was also going to lend value to customer confidence. "If our customers suddenly notice that our product quality has slipped during this time of transition, they will be very likely to go elsewhere... to another airline that is not going through the kinds of changes that we are currently experiencing. On time performance was never more important than it is now. The integrity of our product, the schedule, must be upheld. We must ensure that our passengers remain loyal to PSA." In another management meeting, the message of maintaining customer service was spotlighted: "The best way to ensure that our customers continue to have confidence in us is to continue to provide them with the kind of service they have grown to expect. Our reservation lines should be answered quickly and courteously. Reservations agents should go about their business in a positive way, serving the customer with his travel plans. Ticket and gate agents should be friendly and efficient, always keeping the customer informed if irregular operations occur. And, our flight 
attendants should continue to show their personalities in the same way that put PSA on the map. Customer service, along with on time performance, and along with protecting the image of our smile should be the key to maintaining customer confidence."

Another theme that was prevalent in the content of the meetings that Ray had with his directors dealt with what could be done symbolically to ensure that PSA employees remained committed to the airline. Just as customers needed to see that there was no need to lose confidence in the airline, so the employees needed to understand the same point. Discussion took place around this theme in several meetings.

Obviously, the entire communications plan was an integral part in maintaining employee confidence, as best as they could, during this time of turmoil. However, Ray capitalized on the word pride: "Our employees have always had a sense of pride toward the company and that shows. If we can help employees understand that the PSA smile will never go away, as a matter of pride it will always be within us, then maybe they will still feel that sense of pride in their jobs. Our employees, just like our customers, identify with the PSA smile."

As a result, the company store was stocked with PSA paraphernalia. Employees were buying up everything they could with the PSA logo on it. Everything from PSA t-shirts, to coffee mugs, clocks, duffle bags, and 
umbrellas were being consumed as never before. Even a poster was printed which pictured all of the different types of aircraft that PSA had flown during its history. These were bought immediately and orders were taken for more.

Stories were told about the good old days and a new kind of camaraderie was developing. During the later months of March, April and May of 1987, a farewell to PSA idea grew. Ray indicated in one of his meetings: "There is a kind of energy that is happening about all this farewell to PSA stuff. Many employees want to hold a big farewell party. I think it is something that we should think about endorsing. The more our employees can be open about PSA dissolving, the better it will be for all of us."

Employee confidence was built by encouraging employees to take time to end their relationships with PSA, not just begin with USAir. By fostering a kind of mourning and taking time to feel their loss, the employees of PSA were building confidence because they banded together in this ending or mourning process.

Many critical points were made from the messages given by Russell Ray to his key management team. It should be noted that Russell Ray himself used the term symbol very frequently. It was almost as if he knew he was operating from a cultural symbolic lens because he freely used the language that is often associated with 
that frame of change. Words such as stories, rituals, symbolism, and culture were all consciously used by Ray.

So the themes that were predominant from the series of management meetings with Ray were the strategic use of symbols to facilitate customer confidence and the strategic use of symbols to foster employee confidence. The meetings, then, are important because they show an obvious cultural symbolic emphasis that is insightful to this research.

In looking at Russell Ray as President, four examples were used to paint a picture of actions taken which reflected the internal values of Ray. These examples can be summarized as follows: (1) the way in which Ray expressed stories to create symbols for the company, (2) the actions taken to develop a mission for PSA, (3) the aggressive communications plan that emerged even prior to the merger announcement, and (4) Ray's insistence that corporate goals be established and articulated.

The actions that were taken by Russell Ray when he initiated the idea that a change strategy needed to be developed and executed, demonstrated his commitment to communication.

The video taped message to all employees and the series of management meetings show the influence that Ray had with regard to facilitating the change event.

These actions distinctly reveal a cultural symbolic lens. Although this model of change and the events 
described here will be analyzed in more detail in Chapter $V I$, it is safe to say that the cultural model was operationalized during the change, predominantly in this fourth leg of the overall change plan.

Being a facilitator of change in a culturally symbolic way involves the creation of a vision and then engaging others to pursue that vision. In doing so the recognition of symbols and language becomes a very integral part of organizational change itself. Additionally, if we study organizations and organizational change, we must examine how we think and talk about them, what we use as symbols for expressing meaning within the organization, and if a social world been created. All of these issues are necessary in any endeavor to study organizational change in action.

Essentially, the impacting leader actions in this portion of the case study bring to life a kind of awareness of the importance of this role in a major organizational change such as the merger of USAir and Pacific Southwest Airlines. Change itself requires a new vision, new symbols and new language. The ones that existed before, however, can not be totally erased because they form the basis for comparison of cultures. We gain our understanding of a culture only by comparing it with other cultures.

If all of this can be effectively facilitated along the way, followers can be cared for in a way that nurtures 
commitment, respect and most importantly, smooth transition from the old to the new.

The Grass Roots Movement

The fifth and last category of the overall change event deals with the feedback that was captured from PSA and USAir front line employees. The type of feedback that was collected by the researcher was specifically in written form from the computer communications network. Because these messages were unsolicited commentary, they became raw data that was very pure. The purpose of the computer network was to communicate operational information among employees in various different cities, not to communicate individual views. The PSA and USAir networks linked together in April of 1987; as a result, messages could be sent back and forth between companies.

Whenever communications messages were sent from one station to another, a printed copy was released for posting if appropriate. Essentially the computer communications network was electronic mail. The pieces of mail, however, were sent to every location on the network as opposed to one specific mailbox.

During the months of April, May and June of 1987. after the PSA and USAir computer systems were linked, the computer print-outs contained a voluminous amount of employee expression.

This computer chatter was actually against company policy, as the purpose of this sophisticated computer 
network was to ensure that the airlines were running smoothly. It was not to be used by employees for their own expression of thought. However, because the merger was such an important change in the lives of the employees, the two companies did little to stop this computer chatter.

The grass roots feedback and expression for both PSA and USAir employees that occurred during April through June of 1987 will now be described.

On April 21, 1987, Vice President of Labor Relations Paul George sent a letter to the Teamsters union representative, Marvin Griswold. This letter got into the hands of some employee who then sent it over the computer network. The letter triggered a flood of employee comment on the network, and the grass roots communications movement began.

The letter read:

"Dear Mr. Griswold:

"Your April 17, 1987 letter to me was hand delivered to my office on the afternoon of April 20. Your letter contains a number of inaccuracies and misconceptions. Therefore, the following is being offered in the interest of clarifying the record and in the hope that Teamsters Local 2707 will reconsider its current negotiating position, including its decision not to allow its members to vote on the company's fully integrated 4/10/87 final offer. 
"PSA's proposals were hand delivered to your office on April 16 along with my letter to you of that date. On that day and before PSA's press release the Teamsters chose to publicly disclose the specific status of our negotiations, including the nature of the proposals then pending at the bargaining table. The PSA press release you complained about was disseminated in response to the actions of your local and was consistent with what I advised you of in my hand delivered letter. Since April 9, 1987 when you first presented me with a last minute proposal calling for wage, benefit and work rule snap backs, I have consistently emphasized both verbally and in writing that issues concerning post merger wages, benefits and work rules, like representation, were subjects that PSA neither had authority to negotiate, nor an ability to control. During our meeting in Washington D.C. on April 10, and in my letter to you of the same date, I made it clear that unless the Teamsters were prepared to withdraw its demand for wage, benefit and work rule snap backs, in any form, further negotiations would be fruitless. You have always known that PSA could not negotiate on the post merger issues contained in the Teamsters April 9 demands.

"When we spoke by telephone on April 13, you indicated that Local 2702 had a new proposal which solely addressed supplemental severance outplacement trust fund issues. On at least two occasions during that telephone call, you assured me that the new proposal which you 
wanted to present contained no snap back demands. Based on your representations, I agreed to fly to Los Angeles to meet with you the next morning. Despite your representations, when we met in Los Angeles you presented a proposal that not only contained snap backs, but also contained an obvious substitute for wage snap backs in the form of a demand that, upon the merger, all PSA Teamster represented employees be immediately paid on the basis of the USAir wage scales. During our meeting of April 14, I rejected the Teamsters' proposal and again reiterated that PSA has never had the authority to negotiate concerning the wages, benefits or work rules that would be applicable to PSA's current employees after the merger with USAir. PSA's rejection of the proposal was confirmed in my letter to you of April 16, 1987 which was hand delivered to you. "Your letter of April 17 expressly stated that the Teamsters will not submit the company's fully integrated $4 / 10 / 87$ proposals to the membership for a ratification vote. PSA is obviously disappointed that the Teamsters have decided not to allow the individuals whom it represents to have a voice in determining their own future. As I have indicated on numerous occasions, the $4 / 19 / 87$ proposal represents one of the strongest employee protection packages ever offered in the airline industry. PSA believes that your members should be given the opportunity to vote on PSA's final offer.

"Finally, with respect to your requests that PSA 
return to the bargaining table in order to resolve the remaining few outstanding issues, I will reiterate that PSA has, at all times, been willing to return to the bargaining table to discuss any issues pertaining to the supplemental severance outplacement trust fund. PSA's willingness to return to the table was, and continues to be, conditional on the Teamsters' withdrawal of the demands that (1) PSA Teamsters represented employees receive the USAir rates of pay immediately upon the date of the merger, and (2) that other benefit and work rule snap backs be implemented immediately upon the merger. If I receive a new written proposal from the Teamsters which eliminate these two demands, and assuming you can assure me that there would still be sufficient time to complete the ratification process prior to April 30, 1987 so that PSA can satisfy the condition set forth in the agreement and plan of merger with USAir, I would be more than willing to meet with you for the sole purpose of discussing and resolving the sole remaining issue--the supplemental severance and outplacement trust fund.

- Paul George Vice President, Labor Relations" The release of this letter was the green light that accelerated the grass roots communication movement. The computer chatter that followed was like a dam breaking. Just as the water would surge from the breaking cement so did the expression and communication from both PSA and USAir employees. The first computer message that 
immediately followed from a PSA employee was, "Please be advised the previous message did not come from the main office." The employee who sent this message wanted to state that this letter was confidential and the employee had taken a bold risk to send it over the computer network.

The next message read, "I don't think anyone cares who the message came from, only if the information is valid."

Another employee wrote, "The last telex by Paul George, Vice President of Labor Relations, is a phony. Paul George is on his honeymoon. Call his office and ask."

Anger was beginning to be a common emotion which could be sensed in numerous messages. One such message is typical of them, "PSA employees want to vote. If the Teamsters won't let us, then let's do something about it. This is not the time to sit back and wait to see what will happen. We have bastards dictating our futures. Any USAir employees out there willing to give us some advice?"

At this point, the USAir employees began to get involved in this communications fervor. On May 6, 1987 the first message was sent from a brave USAir employee. "I've been employed with USAir for about 20 years and never have I seen anyone or heard of anyone getting the shaft from my company. USAir treats all of us outstanding. We get the same as most carriers and more 
than others. I grant you some airlines need a union but we are not one of them. Why pay for something when you have a company that is willing to give to you for free. Well not totally free, you have to give them a honest day's work. Let's all just get together and make one strong airline that can not just survive but prosper, and we will all have a secure job for the future."

Another USAir employee expressed these thoughts: "We all hope that your frustrations with the union will turn out successfully. . . From those of us that have worked for an airline represented by the Teamsters-Braniff--let me tell you that USAir management takes better care of its employees. - . You have much to gain and little to lose by opting out of the union."

On May 7, 1987, a USAir employee advised, "Don't let the guys in the black hats feed you a lot of lies. This is a great company and one I'm sure you would be proud to work for."

Still another USAir employee reported, "Ed Colodny is the best airline president in the industry--bar none--do you really think we're lyin'?"

A USAir employee named Dave from Boston sent a message that said, "After working with Lake Central, Allegheny and USAir, you couldn't find a better employer to work for anywhere. They will listen to anything you have to say or ask and find the answer if they don't know. Go with USAir. You won't regret it." 
On May 7, 1987, a PSA employee sent part of Chairman Paul Barkley's letter to all PSA employees over the wire, "There is no turning back the clock. Our future is here, now, in the form of a beneficial merger with USAir. Without the merger, PSA could survive only by cutting costs through station closings, aircraft sales and layoffs. Almost every financial analyst who has recently studied PSA has reached the same conclusion based primarily on the growing presence and strength of United, American and Continental in PSA's traditional markets and the continued expansion of low cost competitors. At the same time PSA does not have the financial resources or computer marketing support possessed by the major airlines competing in our marketplace. We find ourselves caught between two sets of equally aggressive competitors without the tools necessary to compete. Without this merger with USAir, our future as an independent airline would be bleak because our independence in the new reality of our industry is under attack. Life as usual at PSA is not an option. We can't risk losing this merger. We must make the merger with USAir happen."

The word was out that voting on the proposal was ready to happen. One desperate PSA employee wrote, "This vote we will cast will probably be the most important decision we may be faced with in our lives. What we do now will not only affect our own bargaining unit but the other three units as well. Let's face it, no agreement can 
be perfect. I think our union reps have done their very best for us at the table. The agreement has been signed by the company and union, a no vote will not send them back to the table, it will terminate the chance we have to survive. If PSA is forced to compete on its own, it will have to restructure in a drastic way. Layoffs would be a result. Five or ten years ago we could use leverage to force an issue. If we didn't like the way things were going, we could work for the airline next door. . . Not so anymore, those airlines have been a part of the merger mania we are experiencing. Good jobs are a very precious commodity. We all have mortgages to pay, kids to feed, and pension plans to lose. Please, let's consider that we also hold the futures of many other employees in our hands."

Many PSA employees were lobbying for a yes vote on the contract, as exemplified by the previous quote. It was a strenuous time, and USAir employees continued to promote their company to PSA employees, "Just for the record, I've been with this ol' company for close to 22 years. I've seen strikes come and go, seen this outfit handle some pretty gnarly situations but never have I heard of it being unfair or not caring about its people. Not saying it don't make mistakes, it has, but it tried to rectify them when discovered. If you folks can get the problems straightened, we are waiting to welcome you." Messages at this point, from May 7, 1987 on, were 
actually beginning to clutter the system. It was like the airline operation shut down. The number of operationally related messages compared to the messages that were part of the grass roots movement was quite small. The communications movement essentially took over the network, despite PSA managers' attempts to at least lessen it. Stopping the message sending completely was not possible at this time.

USAir employees continued to articulate their views about USAir. "A very warm hello to all the folks at PSA. We are aware that you are holding ratification proceedings of the merger proposals. To let you know the way we feel, we are excited and happy that you have the right to choose to be a part of USAir. USAir has been good to me for 21 years. As with any merger there will be some rough spots, but I believe you will find the USAir management fair and honest with you. True some companies need union representation, however, it is my belief that USAir is not one of them. True my view is slanted but try USAir without a union. Give us a chance, I do not think you will be sorry. Best of luck and get out and vote." PSA employees were trying to set the record straight. There was a lot of conflicting information as to the status of their jobs. One PSA employee encouraged voter turnout: "We have been advised by the Teamsters that in order to vote, you must attend a ratification meeting. I urge you to attend a meeting and vote in favor of the 
agreement to allow the merger to go forward. In order for the merger to go forward, each of the four Teamster represented groups must vote in favor of ratification."

One PSA employee indicated that she was not in favor of the merger by sending a message that said, "Rambo woman says if you're scared, buy a dog."

The response to that message from another PSA employee who obviously disagreed with that message was, "Attention Rambo woman: We can save our money . . you are tough, you can protect us. Get ready to pay all our bills for us when we don't exist."

USAir employees continued to send encouraging messages across the computer network.

"To the Teamsters who are recommending a no vote. stop. We have a round table policy and a grievance system second to none plus a pay scale and benefits package close to the top in the industry. We also enjoy an open door policy both at the station level on up. Big daddy looks out for us workers so we really do not need representation."

"From a 36 year employee of USAir, there is no better piace work. Very employee oriented."

"The only thing you folks could lose would be the right to pay union dues."

"Hope the ratification process is going well. We hear that Teamsters are recommending a No vote. That's up to you, but UsAir is the best there is in the airline 
industry for the way they treat their employees. I say this as a Teamster employee from USAir in Buffalo, Pittsburgh, Philadelphia or Boston."

"We have been at the mercy of USAir from the start and what has it gotten us? We are among the highest paid in the airline industry."

"Ed Colodny is a man of his word and well respected by all of the USAir employees."

"I really believe the PSA people will get a good deal and we will all end up with a strong company. Believe me we don't need unions. Looking forward to meeting and merging with our western allies."

"I have worked for 7 managers in 4 cities in the last 22 years. Looking forward to the next 22 years. Don't worry."

"It sounds like the union is telling you horror stories about other mergers. The fact is that you will be part of one big family. I was with Mohawk Airlines and we merged in April of 1972. We had very strong feelings with Mohawk and were deeply hurt with our loss. It was a loss. But it was for the best. We are all proud to be a family member of USAir and look forward to you, PSA, as a family member. With a strong and fair company like USAir, a union is not needed, it can just confuse the issues. Hope my comments help."

"I was one of the union organizers for Allegheny in 1976 and voted No too. But that was 1976 and this is 
1987. I wouldn't vote for a union here at USAir because the company has been a lot fairer in recent years. Not just Teamsters, any union. True, there are a lot of things that we have no say in, such as the annual raises, when other airlines took cuts, and the Christmas bonuses we have received the last 3 years. We understand there will be no raise this year, but then again, PSA and Piedmont are not cheap properties. A combined PSA/Piedmont/USAir will be a strong airline to be contended with by the biggies. Come on over. We want and need PSA."

"USAir is a great company to work for, and I might add, with. We have always been treated fairly which goes right along with our success. Obviously some work rules are bound to change as we change and the industry changes. But we will be stronger than ever with PSA and Piedmont and will be a competitive force to be reckoned with."

"Just thought I'd chime in. I've been a part timer with USAir for over a year now and really believe that I couldn't be treated any better. I have full insurance benefits, two weeks paid vacation a year and a whole bunch of great coworkers throughout the system. To all PSA part timers, hope to be working together soon."

"To all concerned PSA employees. You can be advised that the only way you could be treated as well as USAir employees is to work for yourself. USAir's equation for success is success divided not only by management but 
employees as well. The employees at USAir are as important as anyone else and all are made to feel that appreciation. You can look forward to working as USAir employees with anticipation, not consternation. Welcome aboard to all at PSA."

Several messages made comments on wage issues. "I don't know much about it. I have real empathy for you folks as you know what you have now but have to look into the unknown. It must be very difficult to make a decision. It's easy to give advice to a person when you're not wearing their shoes. The only way to look at it is what do you have now. A job and a pay scale. What will you have with USAir - a job and a pay scale. I can tell you would like a little more but from what little I know they aren't taking anything away."

"From 15 years experience with USAir and 10 years with an airline which needed a union, I can't see that USAir would pitch you a raw deal. The majority here have the utmost respect and confidence in Mr. Colodny. We have under his leadership become a Cinderella airline in the industry. I like playing on a winning team."

"Many years ago a union was trying to unionize the customer service agents. The union signup forms, with a letter telling us of the benefits, were given to us as we picked up our paychecks. The waste basket in that office had to be emptied several times as most agents threw them away. Over half the basket was filled with envelopes that 
had not even been opened and read. Some were torn to shreds which reflected the vehement opposition to the union drive. These were agents from the two merged airlines and Allegheny. Except for some ramp agents, we felt no need for a union while working for a company which treats us like real people."

"Over twenty years with the company and I can truthfully say they have never done me dirt. If you feel you do a good job for your company, then you can be proud of your work and let it do the talking for you, and USAir will listen. Very anxious to meet our friends out on the coast. Really looking forward to getting to know people that think like we do."

"I've been with USAir 14 years. We are the best. Our president is the best and our managers are the best. It seems like every decision is done with regard not only to the company but to all the employees. USAir has treated us like kings and queens. We are the best."

"In response to the PSA Phoenix operations request for comments, I have 25 years with Lake Central, Allegheny and USAir. Before that 7 years with Ozark. After going through 2 mergers and a name change, I firmly believe all employees were treated fairly and at this time I can think of no company I would rather work for than USAir."

Interspersed with the raving reviews about USAir from USE:Ir employees, there were occasional remarks from some PSA employees that were pointed and somewhat creative. 
An example is this message about one of PSA's Teamsters union representative, "If bullshit was electricity, Ed Rubano would be a powerhouse."

Messages from USAir employees around May 9, 1987 were actually getting a bit dramatic, as exemplified by these remarks.

"You remember the song I have never been loved so much in all my life? They may not please all the people all the time but they try. Most of us have been around 20 to 30 years and hope to be around for awhile yet. We went through mergers with Lake Central, Mohawk and Allegheny, then a name change and everybody pulled together and the results have sure pleased us. Welcome aboard. If you want to complain, you can. If you want to make things better, you can do that also."

"Joining USAir over 10 years ago was one of the best moves that I ever made in my life. This airline is fair, high paying and has been developing in such a positive way over the past few years that I am proud to call myself a USAir employee."

"I was with the company for 3 months when I got cancer and spent many weeks in the hospital and treatments. I had two days of sick time and had many expenses from just moving to take the job. USAir explained that each situation was reviewed individually and if they could they would make a sick time advance. They advanced me 6 weeks plus. When I did come back they 
worked with me for over 3 months to help me back onto the job because I had limited stamina. Without all this I would have been hurting. It was almost 4 years before I got back to normal, USAir working with me all along the way. No one could ask for more."

"What are your options? A buyout from a less sympathetic carrier like Northwest or TWA. Certainly going it alone doesn't look real promising right now." Starting on May 11, 1987 the results of clusters of votes were filtering in. These results were informally communicated over the computer network by employees of PSA. Some of these messages are given below.

"Pasco voted all yes. That's 100\%. Everyone is in favor of the merger."

"Way to go Phoenix. Your YES votes are in. We love you. Any more precincts in yet?"

"Do they count the votes right at the meeting? How did you find out the results?"

"Seattle voted by a show of hands and then called in the vote to Local 2707. Out of $60 \%, 120$ YES, 0 NO."

"Portland votes are in. Even though we're small, we sure are mighty. 20 FOR and 0 AGAINST."

In the middle of these voting results, someone scolded a fellow PSA employee who had complained that he or she was tired of all this computer chatter about the voting. "My dear complainer of Santa Ana. I know of no better way to turn the vote against this merger than by 
your constant complaining. Please stay off the wire... for the merger's sake."

Another PSA employee spoke out about the rumor that some people were voting no because of pressure. "We've been hearing rumors that some agents have voted no after a three hour meeting and very negative presentations given by the Teamsters. Then they regretted their last minute change of mind after it was too late. Unless you are truly, firmly committed to a no vote, don't be influenced by fatigue and a very slanted presentation. Think twice before you cast your ballot. All our futures are at stake."

Interestingly, on May 15, 1987, Vice President of Labor Relations Paul George sent a message over the system which said, "The contract modification ratification vote by the four Teamster represented PSA employee groups will conclude sunday. The votes will be counted the same evening. USAir previously agreed to extend the deadline for completion of the PSA USAir acquisition agreement to May 17 to allow for the vote."

Since it was impossible to stop the communication from front line employees over the computer network, Paul George decided that he too would do some communicating over the wires. He essentially joined the grass roots movement. From May 15 on, various senior managers of PSA began to use the network as an update device, similar to the purpose of the PSA USAir Merger Update. 
On May 17, 1987 the Public Relations Office of PSA released this message over the network. "PSA today announced it has been informed by the International Brotherhood of Teamsters Local 2707, that the agreement between PSA and the Teamsters has been ratified by each of the four Teamster represented bargaining groups in voting which concluded yesterday. 'We are very pleased with the support shown by our employees for this acquisition,' said Paul Barkley, PSA Chairman and Chief Executive officer. 'The acquisition of PSA by USAix is a tremendous opportunity for PSA and its employees to be a vital part of a major carrier in this industry.' Results from Reservations: 350 YES, 67 NO. Flight Attendants: 621 YES, 10 NO. Maintenance: 388 YES, 377 NO. Stations: 934 YES, 155 NO."

The messages continue even after the voting was over. There were expressions aimed at the employees in the Maintenance Department because the vote was so close in that particular work group. "Anybody anywhere know anyone in the auction for a couple west coast maintenance bases - . or perhaps 377 aircraft mechanics . . mentality not guaranteed . . but the price . . cheap - . cheap . . cheap."

Most of the communications at this point were expressed in a tone of celebration. "Tell Ed thanks for his patience. Speaking for Redmond, we are damned happy to be on board. Congratulations, and a huge thanks to all 
who put us here."

Other messages of this sort included, "Well, we did it. We can now be more secure about our jobs and our livelihood. As for me, I'm proud to be a part of USAir, and I think we'll all be the better for this fantastic day."

On May 18, 1987, Vice President of Station Operations Al Crellin released his message, "During the recent months we have had voluminous unauthorized messages generated by station agents. While I understand some of the motivation behind these messages, we cannot continue using the twix for this purpose. Any further unauthorized use of the company computer system will subject you to discipline. So let's get back to running the airline."

This message still did not stop the employees of PSA from sending unauthorized communications. Some of the continued views were, "We hope that the 377 mechanics that voted No have kidney stones that pass as hard as they vote."

Another employee wrote, "Not 11 votes, but 6 . If 6 votes went the other way, we would have been history. Nice to have knuckleheads holding our future."

The last part of May, 1987 passed with a significant decrease in the amount of computer chatter over the wires. As June of 1987 began, so did the escalating number of messages from employees on the network that were not work related. The messages now dealt with how USAir would 
begin integrating the pass and free travel benefits to all employees. As this message exemplifies, "I know we're not suppose to be sending messages over the wire, but look what happened before when we started this. We got the whole darn country involved, including PSA and USAir employees talking to one another. It made checking the print out load more fun. I think we can use this vehicle to be heard. Let's put some pressure on for finding out what is going to happen to our pass benefits. After all that's why many of us are in this business. Let's see what we can do to generate some ideas on this. Let's talk some more."

The first response was, "I'm a USAir employee from the south. I never been west of the Mississippi. Anyone in Bend, wherever the hell that is, want to have lunch?"

"I'm a PSA employee in Fresno. Bend is in Oregon. You know that state near Washington... and I don't mean D.C. If you come on over to Fresno, you'll have an entire station ready to take you out to lunch and show you our splendid city. What are your pass benefits like?"

And, so the fervor began again. From coast to coast, employees were now mischievously and energetically chatting with one another. As one USAir employee said to PSA, "Your pass benefits are better than ours. We have to pay a higher amount and our parents and dependents only have a limited amount that they can use each year. Yours are all unlimited and the fee is less. As far as I know, 
USAir would like to incorporate some of PSA's ideas on this one. We could use a better system."

A flight attendant from PSA got on to the network and said, "What about commuting? I commute from seattle, Washington to Los Angeles. So far, so good. Anyone out there a commuter? Hope it's as easy on USAir as it can be here at PSA?"

The senior managers of PSA were once again concerned, in a light way, about all the chatter that was continuing to happen. They decided that they might be better off adhering to the old cliche, "If you can't lick 'em, join 'em." As such, Morton Rible, Vice President of Administration, released the following message in order to address the views and questions of employees: "Beginning July 1 and continuing through the effective date of the merger, PSA employees and eligible family members (spouse, unmarried dependent children under 21, and parents) will have the opportunity to experience the route system of USAir and Allegheny commuters on an unlimited, space available basis, and no charge." The message went on to read, "USAir employees and their families will be traveling with PSA under similar conditions. After the merger is completed, all PSA employees and retirees will adhere to USAir's existing pass policies."

Employees showed their delight as evidenced by this statement: "PSA passes will be honored on USAir and USAir passes will be honored on PSA. That's the very best news 
I've heard all year. This merger is already unbelievable. Pinch me. Surely, I'm dreamin'."

Morton Rible further communicated: "All PSA personnel should request PSA trip passes through their department head as they currently do. Silver pass holders should obtain trip passes from PSA prior to proceeding to a USAir gate. PSA trip passes will be honored at USAir gates. PSA employees will be boarded after USAir employees in the order of arrival at the gate."

More and more employees sent their views of support over the wires. To get to the heart of an airline employee, the best factor to introduce is pass benefits. However, there were some differences in USAir's rules from PSA's rules. Those rules were described by senior managers over the twix: "There are some differences between PSA's policies and those currently existing at USAir. No companion passes are available for travel on USAir. No positive space vacation passes are available for travel on USAir. USAir's dress code does not allow boarding of anyone dressed in jeans or denims of any kind."

Employees of USAir retorted by sending messages such as: "BOY, PSA should have bought USAir. At least we would have a better pass benefit package."

Employees of PSA responded by saying: "It's not very appealing to be last on the list. The fact that USAir will place us on the aircraft only after USAir employees 
makes us feel like step children. Where's all this talk about camaraderie and teamwork. In fact, I thought I heard Ed Colodny even call it family."

In the midale of June of 1987, an employee of PSA was disciplined for using the computer network for personal views. At that point, all computer chatter ceased. What continued were messages pertaining the operation of the airline and on some occasions there were condensed versions of the PSA USAir Merger Updates and other memorandums and letters. Just as dramatically as it started, the expression of opinions ceased.

This fifth leg of the overall five legged change strategy was both personal-therapeutic and political-economic in nature. The lenses that were predominantly used came from those two models of change. The grass roots movement was essentially part of the unfreezing process which is strongly linked to the personal-therapeutic model. The fact that this unfreezing led to the emergence of an extremely strong interest group unveils the political-economic model in action. 


\section{CHAPTER VI}

SUMMARY, CONCLUSIONS AND DISCUSSION

The purpose of this study is to determine the degree to which the organizational actions of Pacific Southwest Airlines exemplify the predominant models of organizational change. In order to fulfill the purpose of this study and to sufficiently answer the associated research questions, this researcher described the change process involved in the acquisition of PSA by USAir. The following segment of this report presents a summary of the significant points associated with each of the five change actions. Since each of the five change actions are essentially a different pair of eyes viewing the change event, a review of the critical points as to how those eyes saw the world are important. From those significant points, conclusions will be drawn by the researcher as to the relationship between the change action and the dominant models of change. When specific conclusions are drawn one at a time for each change action and the associated models of change, then some overall conclusions will be drawn with regard to the collective view of the case study. The latter is the heart of this research. It is here where the four research questions which were part of the purpose of the study will be once again asked and 
answered. Furthermore, this segment of the report will discuss the implications for future research in the area of organizational change and the strengths and weaknesses of this particular case study.

Summary and Conclusions

Each of the five change actions will now be discussed, consecutively so as to build a point of view which ultimately will synthesize the actions taken with each respective relationship to the models of change. First, a summary and conclusions will be drawn about the internal mechanisms for articulating change (PSA News and PSA USAir Merger Update). Next, conclusions will be discussed about the external mechanisms for articulating change" (newspaper articles). Then, a summary of the programmatic processes" (the workshop entitled, "Leading in Changing Times") will be developed. Next, conclusions will be presented about the impacting leader actions of President and Chief Operating Officer Russell Ray. Finally, conclusions will be drawn from the grass roots movement or the employees' views of the change.

\section{Internal Mechanisms for Articulating Change}

The primary conclusions that this researcher has developed from the information gathered from the internal mechanisms for articulating change evolved from the systems-organic and the political-economic models of change.

The fact that the PSA USAir Merger Update was even 
developed, written and disseminated clearly demonstrates the view that communicative intervention was necessary in order to educate the members of the organization about the change event. This is evidence of organizational development. The goal of the internal mechanisms for articulating change, like the overall goal of organizational development, was to link conceptual framework and strategy while renewing the organization through a process of having people within the organization learn and interact through a set of interventions. This change action was a process involving change on the interpersonal level, the subsystem level and the overall organizational level.

Specific examples of when the internal mechanisms for articulating change reflected the systems-organic model of change include the following.

1. Immediately after the December 8, 1986 announcement of the agreement to acquire PSA, an intervention was planned and communicated. The December 9, 1986 PSA News Update announced that USAir's Chairman Edwin Colodny would be at PSA headquarters to interact with seven different work groups in six separate interventions.

?. The first issue of the PSA USAir Merger Update was symbolic of the company's desire to not only communicate to employees, but to get feedback from employees as well. The question and answer format of the 
communications vehicle shows the interplay.

3. Interaction, intervention and feedback played a vital role in the change actions viewed from a systems-organic lens. Only four days after the announced agreement to merge with PSA, the company had blitzed the PSA system with several communications in this question and answer format, which in itself implies interaction, and which had the intent of helping the people in the organization learn.

4. The December 19,1986 release of PSA USAir Merger Update spotlighted the videotaped message from PSA President Russell Ray. The message was to communicate and educate employees on the background of why the merger happened.

5. A communications hotline was created and communicated. The hotline was evidence of the executives' continued efforts to demonstrate that the company was there to listen. PSA cared about what the employees needed to ask and insisted that communication responses would be accurate, honest and consistent.

6. Throughout the change cycle, the managers of PSA continually reminded employees that there were numerous vehicles available to get information, learn, and give information about the change. This constant and consistent message of PSA managers wanting to communicate with employees is noteworthy.

7. On January 30,1987 , the PSA News Update 
announced that nine meetings would be set up in many geographic locations so that employees could get answers to their questions regarding the profit sharing plan and the labor protective provisions. The meetings were intended to be open forums where employees could express their views as well as request information they needed in order to vote for or against the merger.

8. In March, 1987, when TWA and Piedmont entered the picture, right in the middle of an already highly ambiguous time, the news and communications vehicles published by PSA focused on those events, so again employees and the overall organization could learn the issues.

These examples reflect the predominance of the systems-organic model of change. Of all of the models of change, this model stands out as one which clearly prevailed during this part of the change action.

The internal mechanisms for articulating change were primarily systems-organic in the early stages and became increasingly political in the later stages. Like any organization, PSA was political in nature; and like any organizational change of this depth and breadth, political behavior was paramount. Specific examples of when this change action reflected the political-economic model of change include the following.

1. The political view became evident in the January 13, 1987 PSA USAir Merger Update. A variety of different 
questions pertaining to special interest groups emerged. The different groups or people mentioned were the Department of Transportation, the Teamsters, PSA company officers and USAir President Ed Colodny.

2. On January 22, when the PSA pilots union announced that an agreement had been reached, political behavior was set in motion. The fact that PSA had successfully concluded contract negotiations with this employee group, a group that is known for its leadership and policy setting initiative, and that the pilots' contract was the first such agreement, was intended to shift any anti-agreement thinking and any tactical delays in negotiating.

3. When the noncontract employees followed with their agreement to the provisions of the merger, the special interest groups in favor of the merger were growing, but thexe were still opposing coalitions with which the managers had to deal. Nonetheless, a political focus was emerging as the voting groups aligned in favor of the merger.

4. On February 17, 1987, information was released that still another group had joined the pro merger coalition--the PSA dispatchers. This action was significant since three groups had now approved the merger.

5. As of March, 1987, the question and answer format of the PSA USAir Merger Update subsided. Instead, 
a more narrative style was used which seemed to focus on the groups that approved the merger. Certainly that change in style reflected that a more political lens was viewing the world.

6. On March 5, 1987, the directors of PSA communicated that the United States Department of Transportation approved the merger.

7. On March 11, 1987, the managers of PSA communicated that the PSA crew controllers approved the merger.

8. On March 16, 1987, the shareholders of PSA voted to approve the acquisition.

9. The Teamsters were holding out. In a tactic designed to put pressure on PSA and USAir and to stall the agreement process in the hope of gaining more power, the Teamsters filed a lawsuit against PSA.

10. PSA declined to arbitrate, which was the essence of the lawsuit, and the federal court ruled in favor of PSA and dismissed the teamster lawsuit.

11. In an effort to put pressure back on the Teamsters, the senior officers communicated on March 24, that the date for the acquisition to be completed had been moved forward.

12. The Teamsters resisted this pressure. They continued to hold out. As a result they regained some power and influence as the feasibility of the merger occurring as planned became vulnerable. 
13. The Teamster resistance allowed the union officers to mobilize resources as they gained the kind of publicity they wanted by resisting USAir's demands for immediate concurrence.

14. Between April 20 and 28 of 1987, PSA employees, a special interest group of their own, began to manifest their anger. This anger put the ultimate pressure on the Teamsters, and the officers finally agreed to put the agreement up for vote. The favorable vote secured the merger.

The shape of this change action evolved out of the special interest groups and the coalition forming process. The very essence of the political-economic model of change was in such actions.

The systems-organic and the political-economic models of change best summarize the internal mechanisms for articulating change. The first conclusion regarding the change action as it relates to the models of organizational change is visualized in Figure 43 . The darkened cells represent those models of change that best explain why certain internal mechanisms were used by PSA to articulate the change event. The undarkened cells represent those models of change that may have some explanatory power, but far less than the two models that are dominant.

\section{External Mechanisms for Articulating Change} The main conclusion that this researcher has with 


\section{Dimensions of Planned Organizational Change}

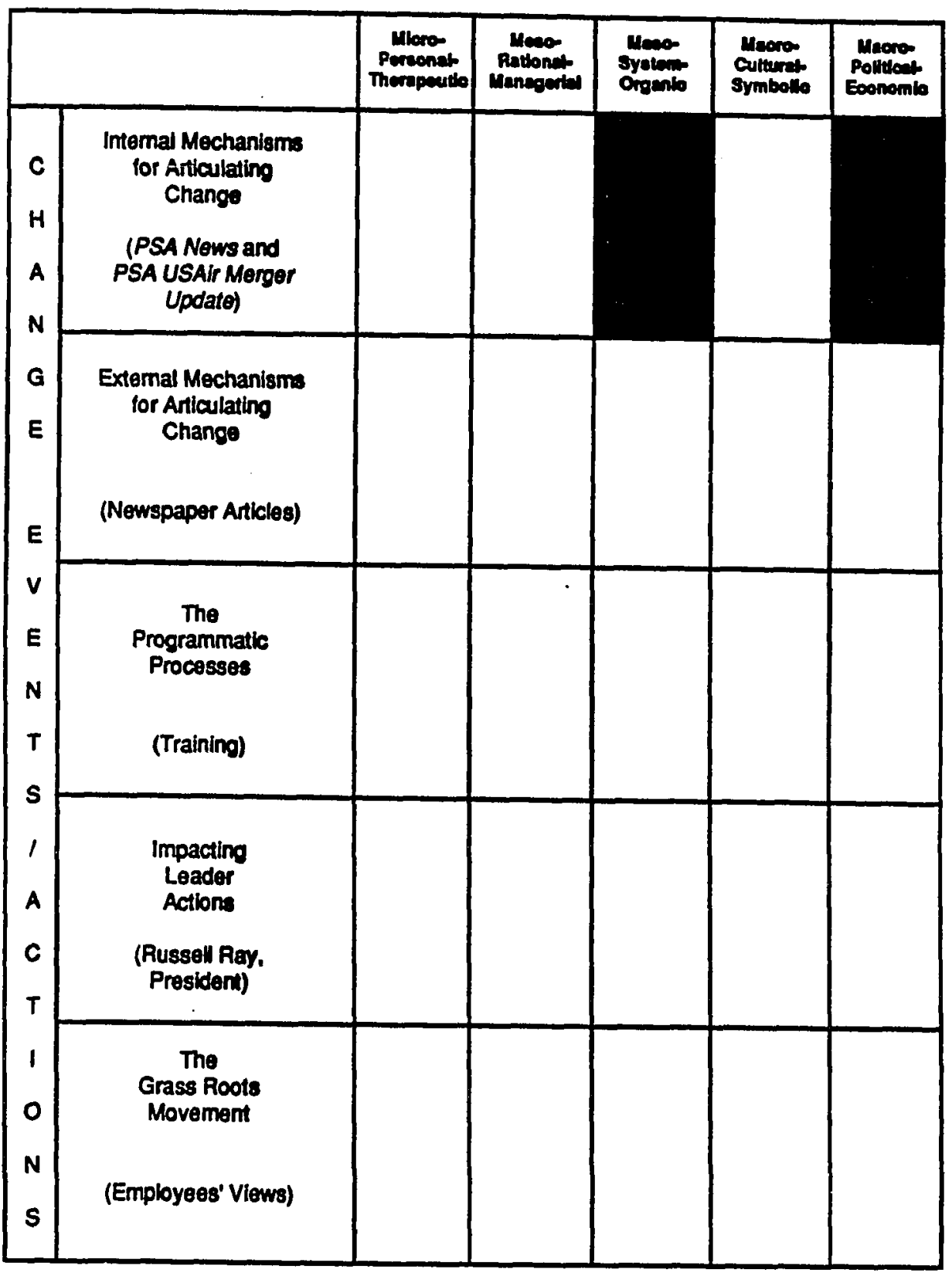

Figure 43. Systems-organic and political-economic models of change are predominant when viewing the internal mechanisms for articulating change. 
respect to the external mechanisms for articulating change is that the lens for viewing evolved from the cultural-symbolic and the political-economic models of change.

The recognition of symbols, rituals, language and other cultural aspects of an organization cannot be ignored when an organizational change is in action. Such is the case with PSA's symbols, rituals, language and other cultural aspects. Of particular relevance here is the extent to which the members of the press capitalized on the PSA smile as a major story during the acquisition process.

Specific and significant examples of when the external mechanisms for articulating change reflected the cultural-symbolic model of change include the following.

1. On the morning of December 8,1986 in the hometown of PSA, the press announced the intended merger of PSA by USAir in a highly emotionalized and culturally symbolic way. Words chosen for the headlines capitalized on the symbolism of PSA growing up and flourishing in southern California, as if the airline were a person that had just died.

2. In mid-December, the save-the-smile movement began. The press captured and sensationalized the smile of PSA as a major story. The question, of course, was would the PSA smile stay and be painted on all USAir airplanes too, or would it be painted over and die some 
culturally agonizing death?

3. The identity of an era was correlated to the PSA smile. The identity of that era was sweeping the press in stories such as "Please Don't Stop Smiling, PSA" and "USAir May Catch PSA's Smile and Keep It."

4. In January of 1987, the story of the symbol of PSA, the PSA smile, continued to be a dominating news story. The history of the PSA smile was told, the marketing analysis of the effectiveness of the PSA smile as it related to consumers was described, and the various predictions as to the disposition of the PSA smile were rampant.

5. The PSA BAe 146 aircraft was an object of the symbol of PSA since it was named, "Smiliner." This airplane was written about in newspapers as if it were a person. The "Smiliner" was a protagonist in the continuing story of the PSA smile. The antagonist was USAir.

6. Many newspapers featured pictures of the PSA smile in the form of photos of airplanes, employees, documents, such as the PSA schedule and buttons.

7. Even in the months of May and June of 1987 writers for the press began expressing that the PSA smile was in the hearts of the passengers of PSA and employees of PSA. The story of the smile moved from literal to highly symbolic. Like the concept of dignity or respect, the smile was something that was within people. 
8. Finally, the members of the press revealed that PSA would lose its corporate identity, effective January, 1988, but that the grin would remain for awhile on the airplanes and would last forever in people's hearts.

These examples reflect the dominance of the cultural-symbolic model of change. Of all the models of change, the cultural-symbolic model stands out as one which directly prevailed with the external mechanisms for articulating change.

Even more dominant was the political-economic model of change. This model sees organizations as political systems with political actors. The actors have their own interests and stakes and stands. Coalitions are framed within a political environment and the organization changes as a result of shifts in rewards, supply and demand, interest groups, negotiation and bargaining. Clearly, this view was exemplified by the writers of the numerous newspaper articles that reported the PSA-USAir merger development. Hard hitting instances of when this change action reflected the political-economic model of change include the following.

1. In late December of 1986, the San Diego Union broke the story about the potential conflict between PSA and the Teamsters' Local 2707.

2. The first pro merger coalition was formed when the pilots of PSA agreed to the provisions of the merger, and the story began. The pilots' agreement represented 
the first consensus in favor of the merger.

3. In January, 1987, the United States Department of Transportation gave tentative approval to the merger. Simultaneously, the press editors were stirring up a story by suggesting that there could be mid-merger turbulence as PSA employees who belonged to the Teamsters union found themselves in the powerful position of being able to stall or possibly block the proposed acquisition.

4. In February, 1987, the thrust of the news focused around two primary issues. The first was the continued resistance on the part of the Teamsters coalition to reach an agreement regarding the contract provisions for the proposed merger. The second was the fact that the PSA dispatchers had reached agreement on the contract changes.

5. Pressure on the Teamsters from its members began. The Teamsters' position was being opposed as exemplified by this headline: "PSA Attendants Urge Teamsters to Agree to Contract Changes." The Teamsters responded by telling the press that the petitions were based on erroneous assumptions about USAir's proposed acquisition of PSA. Clearly, a division between groups had taken place.

6. Action groups formed consisting of PSA employees against the Teamsters. The groups were designed to publicly pronounce their collective views against the opinions of the Teamsters. 
7. The Teamsters took action too. They sued PSA in an attempt to force arbitration. The press summarized this struggle for power and influence in an article entitled "Teamsters Suit Could Peril PSA Merger."

8. The Southwest Dispatchers Association was the second of four major unions representing PSA employees to agree to the merger provisions. This story was sensationalized.

9. The four dominant news issues in the month of March, 1987 were TWA's play for USAir and USAir's bid for Piedmont, the PSA Crew Controllers contract agreement, the shareholders approval of the merger and more unrest between the Teamsters union and its membership.

10. A grass roots effort to replace the Teamster had begun when PSA employees were unable to get detailed information about the negotiations to modify labor contracts. The Teamsters were being ousted!

11. During the month of April, 1987, the press presented the PSA-USAir merger like a highly political suspense movie. The events that were published were reaching a climax. PSA as an independent carrier was weakening. Time was running out, and the Teamsters represented employees of PSA wanted to vote on the issue.

12:- With only one week left until the merger deadine, employees of PSA were in a turmoil that moved them to anger over the Teamsters' actions. The members placed constant pressure upon the Teamsters through 
aggressive communication and picketing.

13. Voting for the merger provisions finally happened. The press waited. On the morning of May 18, 1987, the news revealed that the Teamster members voted in favor of merging with USAir.

14. Once the highly political activities of the change event subsided, so did the press coverage.

Like a pair of eyeglasses, the external mechanisms for articulating change were political-economic as evidenced by the previous key points. The very essence of the political-economic model of change was once again evident in the actions of various groups and individuals as they participated in the change event.

The cultural-symbolic and the political-economic models of change best explain the external mechanisms for articulating change. The second conclusion regarding the change action as it relates to the models of organizational change is visualized in Figure 44. The darkened cells represent those models of change that best explain why certain external mechanisms were used to articulate the change. The undarkened cells represent those models of change that may have some explanatory power, but far less than the two models that are dominant. The Programmatic Processes

The primary conclusions that this researcher has developed from the information gathered from the programmatic processes evolved from the systems-organic 
Dimensions of Planned Organizational Change

\begin{tabular}{|c|c|c|c|c|c|c|}
\hline & & 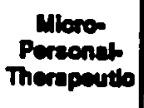 & $\begin{array}{c}\text { Macon } \\
\text { Rattonat } \\
\text { Menegerter }\end{array}$ & $\begin{array}{l}\text { Meso- } \\
\text { Syptemb } \\
\text { Oreanto }\end{array}$ & 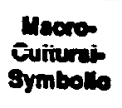 & $\begin{array}{l}\text { Meoro- } \\
\text { Polldiout } \\
\text { Eoconomile }\end{array}$ \\
\hline $\begin{array}{l}\text { C } \\
\text { H } \\
\text { A }\end{array}$ & $\begin{array}{l}\text { Intermal Mechanisms } \\
\text { tor Articulating } \\
\text { Change } \\
\text { (PSA Nows and } \\
\text { PSA USAir Merger } \\
\text { Update) }\end{array}$ & & & & & \\
\hline$E$ & $\begin{array}{c}\text { Extemal Mechanisms } \\
\text { for Articulating } \\
\text { Change }\end{array}$ & & & & & \\
\hline $\begin{array}{l}V \\
E \\
N \\
T\end{array}$ & $\begin{array}{l}\text { The } \\
\text { Programmatic } \\
\text { Processes } \\
\text { (Training) }\end{array}$ & & & & & \\
\hline $\begin{array}{l}\mathrm{C} \\
\mathrm{T}\end{array}$ & $\begin{array}{l}\text { Impacting } \\
\text { Leader } \\
\text { Actions } \\
\text { (Pussel Ray, } \\
\text { President) }\end{array}$ & & & & & . \\
\hline $\mathbf{s}$ & $\begin{array}{c}\text { The } \\
\text { Grass Roots } \\
\text { Movement } \\
\text { (Employees' Viows) }\end{array}$ & & & & & \\
\hline
\end{tabular}

Fiqure 44. Cultural-symbolic and political-economic models of change are predominant when viewing the external mechanisms for articulating change. 
and the personal-therapeutic models of change.

The fact that the senior managers of PSA approved, endorsed and fully supported a formal intervention for the entire management team of the company, certainly suggests a deliberate organizational development or systems-organic perspective. The intervention in this case was a one day management development workshop. The intervention was designed to address the problems inherent in the change event from a systems-organic framework. At a time when change and corporate life are synonymous, human resources executives must learn to support their clients in understanding the dynamics of change. While there are many well developed approaches to managing complex change on a rational or systems level, what was missing were equivalent actions from other change models that help affected people stay on track in an efficient and productive way.

This researcher deliberately initiated the intervention called "Leading in Changing Times" to capitalize on the value of the systems-organic lens and to blend it with the personal-therapeutic model of change. Specific examples of when this change action reflected the systems-organic model of change include the following.

1. The researcher believed that a seminar intervention would be vital for managers of PSA so that development, knowledge, education, skill building, 
technique building and understanding of the change would occur. Without this learning, the operation of the airline during the transition could be in jeopardy, productivity could sufficiently decline and the merger could be thwarted.

2. The intervention was designed to support PSA managers not only so that the business would run normally, but so that managers would not feel the stresses and frustrations which are associated with the type of change that a merger process inevitably causes.

3. Spending a full eight hour day with colleagues in a structured intervention was necessary to encourage managers to help themselves and their employees to see the change from as many lenses as possible.

4. A series of informal discussion groups were formed so that feedback could be received and ultimately incorporated into the design of the workshop.

5. Functioning in an advisory capacity, the group members openly expressed their views regarding the questions asked by the researcher. The feedback 1oop was in place.

6. Feedback was also received from senior vice presidents about what they expected from the management team during the transition period of the acquisition.

7. The program, "Leading in Changing Times" was a specific systems-organic action which PSA executives took to help facilitate the change event at PSA. 
8. The content of the entire program meant that individuals had to learn, thus allowing the organization to change and shift. The interpersonal, the subsystem, and overall organizational levels were impacted by the way this intervention affected the participants.

These examples reflect the predominance of the systems-organic model of change in the programmatic process. Considering all of the other change models, this model stood out as obviously one best explained this change action. Since the change action was in itself an intervention, the program automatically blended with the systems-organic paradigm.

Equally as obvious was the personal-therapeutic model of change. Changes that originate at the individual or personal level are crucial if resistance to a merger is to be eventually overcome. The internalization of change at the interpersonal level is essential. Organizational change results only when individuals believe and value the change. This model of change gets to the very root of the change itself. The personal-therapeutic model focuses on the psychological implications of change and shifting the personal views and ways of thinking of the participants from old to new constructed realities.

A synthesis of the more pertinent examples from the programmatic processes which clearly reflect the perspective of the personal-therapeutic model of change follow: 
1. The researcher determined from the needs analysis she did in preparation for the intervention that a personal-therapeutic emphasis was necessary. From a program design point of view, the researcher discovered that managers needed to feel more prepared, have a better understanding of what was expected of them during the change cycle, experience the loss, learn how to overcome resistance to change, help employees evaluate conflicting information and basically learn about the reasons why people react to change the way they do.

2. The workshop began at the interpersonal level. A discussion took place which focused on questions about how the managers themselves were dealing with the change and how they felt their people were dealing with the change. Heated discussion ensued wherein deep seated emotions were vented. The discussions were debriefed on an individual level.

3. The intervention was designed to unfreeze the participants by getting at the deep issues concerning each person.

4. The fact that the natural human resisters to change were part of the curriculum demonstrates the personal-therapeutic focus in the content of this program.

5. The program cointent dealt with the idea that managers needed to learn not only how people react to change, but also to learn how to recognize the reactions of people having difficulty going through change. 
6. Listening can make the road through a change event, if not free of bumps, at least smoother than it might be otherwise. This was a major premise modeled, talked about and encouraged during the intervention.

7. People involved in the change need personal attention as well. Their tensions and fears may increase as the change moves forward. If not caught early, these behaviors can create new obstacles to achieving a successful implementation of change. The fact that the workshop occurred is evidence that this kind of personal attention occurred.

8. A personal-therapeutic view would require the manager during any change to focus not only on getting to the end result, but to also focus on facilitating the change while simultaneously getting to the end result. This premise was the backbone of the intervention.

The personal-therapeutic lens provided a crystal clear explanation during this third leg of the overall change strategy. It is a lens that can often be overlooked, and it is a lens that is absolutely necessary if a change can be real.

The systems-organic and the personal-therapeutic models of change explains much of what happened during the programmatic process. The other models of change were represented to some extent as well but were less pronounced. The third conclusion is illustrated in Figure 45. Once again, the darkened cells represent those models 


\section{Dimensions of Planned Organizational Change}

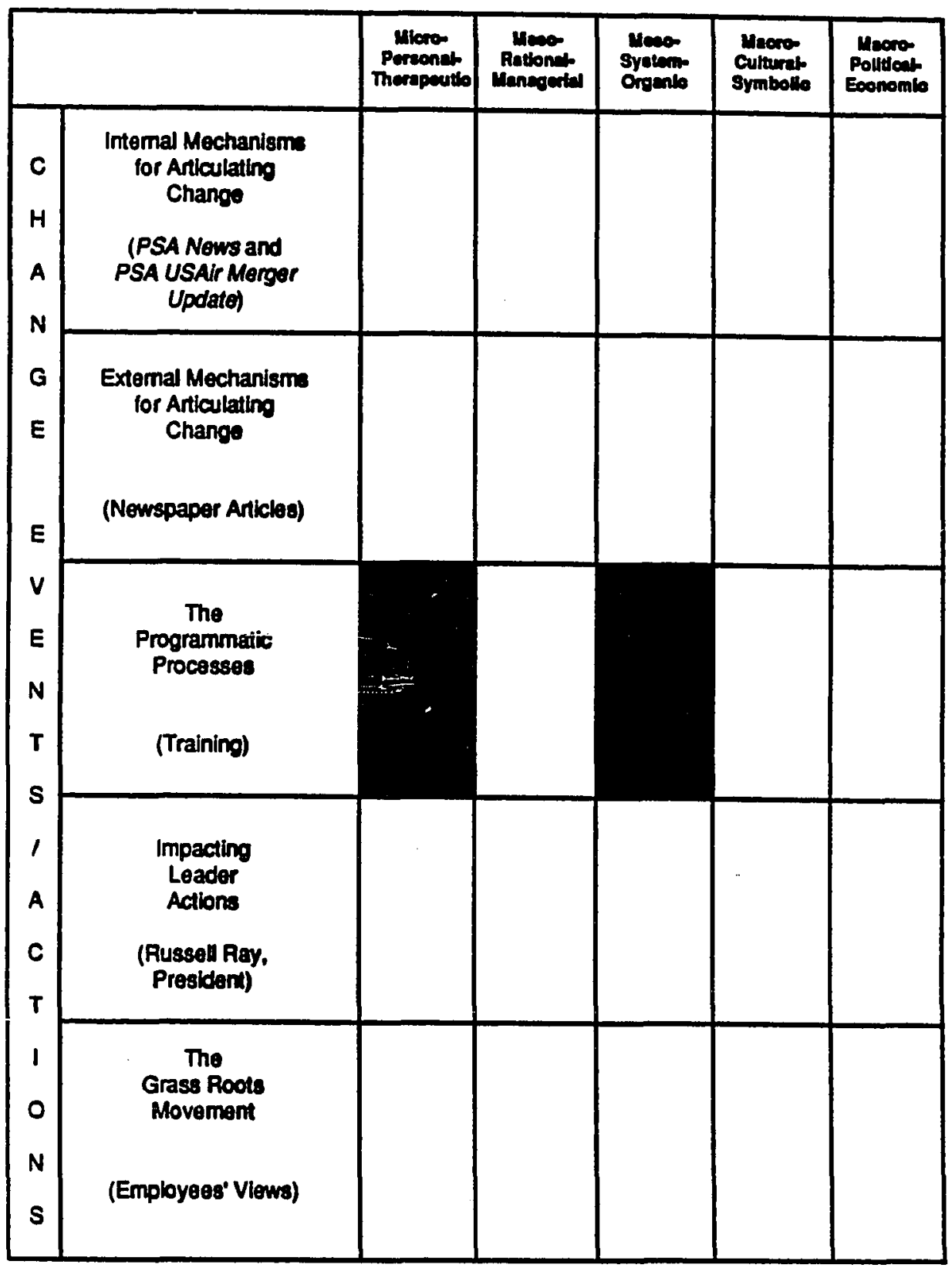

Figure 45. Systems-organic and personal-therapeutic models of change are predominant when viewing the programmatic processes. 
of change that were more apparent for the programmatic process. The undarkened cells are intended to make the point that those models of change provided little explanation on the programmatic processes.

The Impacting Leader Actions

The main conclusions that this researcher has developed from the information gathered from the impacting leader actions evolved from the cultural-symbolic and the systems-organic models of change.

Change within organizations requires new visions, new symbols and new language. The visions, symbols, and language that existed before, however, cannot be totally erased because they form the basis for comparing cultures. The members of the organization gain insight and a deeper understanding of a culture when it is compared with other cultures. Being a facilitator of change in a culturally symbolic way involved the creation of visions and then engaging others to pursue those visions. In doing so the recognition of symbols and language becomes a very crucial part of the organizational change process itself.

The actions taken by the perceived leader of the organization bring to life a kind of awareness of the importance of this role in a major change such as a merger or acquisition. Specific examples of when this change action reflected the cultural-symbolic model of change include the following.

1. Russell Ray deliberately created stories so that 
they could be told within the organization. He specifically believed that stories were symbols of how a culture could be built within a company.

2. Ray used his charisma to his advantage and told organizational stories. Frequent stories were told of Ray popping into a crew lounge or break room when it was least expected. Ray used these types of events as vehicles for conveying meaning.

3. The best way to appeal to the hearts of any PSA employee was to capitalize on the symbolic PSA smile. To allude to the fact that PSA's smile was a "treasure on the west coast" and treat it as if it were suddenly going to go away, pulled at the heart strings of most employees. Ray did this as an expression of the importance of the smile as a symbol.

4. The constant and consistent use of such words as pleige, pride, truth, commitment, excellence, enthusiasm, PisA personality, hearts, and smile suggests that Ray could use a language that was culturally symbolic in nature.

5. Employee confidence grew as Ray encouraged employees to have time to end the idea of PSA. Like a kind of fostered mourning, or a time span to feel 1oss, the employees of PSA banded together in the ending or mourning phases. Ray facilitated these transitions.

6. Ray had a deep commitment, both from a personal as well as a professional level, toward the development and execution of a change strategy. As such, this 
commitment permeated the organization as a symbolic expression of care and concern.

7. Ray also facilitated the use of the PSA smile to create stories. A story was told during a meeting with Ray of a customer who had written and indicated that taking the PSA smile out of California was like taking Mickey Mouse out of Disneyland. Ray told this story over and over again in the halls, offices, and lounges. In fact, there was a kind of uprising that emerged shortly thereafter about preserving the PSA smile.

These specific summary points are representative of the dominance of the cultural-symbolic model of change in Ray's action as a leader. Of the five primary models of change, Ray favored words and actions that reflected the cultural-symbolic model of change.

Another model of change that appeared to be equally dominant was the systems-organic model of change. Ray's actions tended to be intervention oriented. His primary purpose was to facilitate learning on the part of the members of the organization. The communications and feedback processes were so intricately designed and fostered, as were the deep belief system surrounding the ideal of honest and open communication. Specific examples of when the impacting leader actions evidenced the systems-organic model of change are:

1. Ray was compelled to develop a specific focus and direction for the organization. As such, he initiated 
a process or series of interventions, coordinated by an outside consultant, to mutually develop the rally points for the organization.

2. The strong belief in communications was paramount to Ray. As such, he initiated a comprehensive communications plan which consisted of several components, most of which involved interventions, feedback, learning forums, and more.

3. Through another series of interventions, Ray, along with his senior management team, established the corporate goals for the organization.

4. Ray fully recognized, in a classic systems-organic way, that the PSA organization had to renew. Like an organism, PSA had grown, developed, was now changing and would ultimately, die. Like any system, the interrelated and interdependent parts needed to be internalized in order for a massive change such as the merger to successfully happen. This systems-organic view of organizations was the basis from which Ray initiated the overall change strategy team.

5. A deliberate attempt was made to ensure that employees had the chance to see the change event from as many perspectives as possible. This would create the learning that is so valued in the systems-organic mode.

6. Ray and the entire change strategy team operated from the basic belief that PSA employees needed to be attended to. This belief stemmed from a genuine concern 
and care about the employee population as numan beings.

7. A minimum of nine interventions were planned and implemented for the purpose of ensuring that the senior management team of PSA had the information the executives needed to manage effectively. Ray structured his managers' meetings in a way that allowed for an open and honest information flow.

8. Ray was available and visible. He was approachable by employees and he frequently engaged in informal interventions in the lunch room with small groups of employees.

The cultural-symbolic and the systems-organic models of change can best summarize the impacting leader action segment of this research. The fourth conclusion regarding the change action as it relates to the models of organizational change is visualized in Figure 46. The darkened cells represent those models of change that best explain why the impacting leader actions were used by PSA to articulate the change event. The undarkened cells represent those models of change that may have some explanatory power, but far less than the two models that are dominant.

The Grass Roots Movement

The primary conclusion made by this researcher is that the grass roots movement viewed the change from a personal-therapeutic and a political-economic lens.

The personal-therapeutic model of change suggests 


\section{Dimensions of Planned Organizational Change}

\begin{tabular}{|c|c|c|c|c|c|c|}
\hline & & 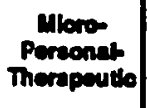 & 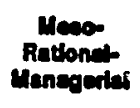 & $\begin{array}{l}\text { Monor } \\
\text { Syyolem: } \\
\text { Orgento }\end{array}$ & $\begin{array}{l}\text { Mecoro- } \\
\text { Chilevert. } \\
\text { Symbollo }\end{array}$ & 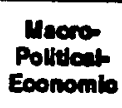 \\
\hline $\mathbf{H}$ & $\begin{array}{l}\text { Internal Mochanisms } \\
\text { for Articulating } \\
\text { Change } \\
\text { (PSA Nows and } \\
\text { PSA USAAr Merger } \\
\text { UPdate) }\end{array}$ & & & & & \\
\hline E & $\begin{array}{l}\text { Extermal Mechanisms } \\
\text { for Articulating } \\
\text { Change }\end{array}$ & & & & & \\
\hline $\begin{array}{l}\mathbf{E} \\
\mathbf{N} \\
\mathrm{T}\end{array}$ & $\begin{array}{c}\text { The } \\
\text { Programmatlc } \\
\text { Processes } \\
\text { (Training) }\end{array}$ & & & & & \\
\hline $\begin{array}{l}\text { I } \\
\text { A } \\
\text { C }\end{array}$ & $\begin{array}{l}\text { Impacting } \\
\text { Leader } \\
\text { Action } \\
\text { (Russell Ray. } \\
\text { Presiderin) }\end{array}$ & & & & . & \\
\hline 1 & $\begin{array}{c}\text { The } \\
\text { Grass Roote } \\
\text { Movement } \\
\text { (Employees' Vlows) }\end{array}$ & & & & & \\
\hline
\end{tabular}

Figure 46. Cultural-symbolic and systems-organic models of change are dominant from viewing the impacting leader actions. 
that change originates at the individual or personal level. It focuses on the psychological perspectives of the change and the movement of personal views and ways of thinking from the old to new constructed realities. Never was this more prevalent in this case study than in the grass roots movement. The grass roots movement itself began as a result of an individual need to express individual views. A summary of some of the more pertinent examples from the grass roots movement which clearly represent the perspective of the personal-therapeutic model of change are as follows.

1. The feedback data collected was in the form of unsolicited commentary from a sophisticated computer network which the PSA and USAir employees used in an unauthorized way to express individual thought.

2. The release of a letter to the union from vice President of Labor Relations Paul George was the green light that accelerated the grass roots movement. The messages sent after the Paul George's message expressed a lot of anger.

3. PSA and USAir employees voiced their concerns, their worries and their frustrations over the wire. Such messages were equivalent to the classic unfreezing process in the personal-therapeutic model. Employees initiated a communications movement which essentially took place over the network, despite some attempts by PSA managers to stop it. 
4. Every message was individualized. Message after message appears on the printouts. Suffice it to say that each person, either from PSA or from USAir, felt that he or she had something of value to say. The network suddenly provided a framework for them to speak out.

These statements are illustrations of the predominance of the personal-therapeutic model of change in the grass roots movement. The fact that the messages occurred, occurred in such volume, and occurred without authorization and against policy is representative alone of the need that each individual had to contribute his or her view.

The political-economic model of change was equally important to the grass roots movement. The employee group had become a powerful coalition in the merger process. Political behavior became evident in the context of the messages that were sent over the computer network. The network itself became an action channel for employees to be heard. Some specific examples of when this change action evidenced the political-economic model of change are as follows.

1. On April 21, 1987, the message from the Vice President of Labor Relations triggered a surge of employee messages because the employees were outraged with what the letter said: that the union was holding up the merger deal. Employees began to speak out and join in the change process more and more. Suddenly, a large and powerful 
coalition had developed.

2. One employee said, "If the Teamsters won't let us, then let's do something about it." This message united the employee group, and followers began speaking out.

3. Even USAir employees joined the coalition. On May 6, 1987, the USAir employees began to get involved in the communication fervor. Statements such as "Don't let the guys in the black hats feed you a lot of lies," were not uncommon. The coalition had support.

4. The computer network became a political focal point for articulating voting strategy. The word was out that voting on the proposal was ready to happen. PSA employees expressed their concern, and it was a stressful time. USAir employees continued to promote their company to PSA employees thereby influencing the thinking of PSA employees.

5. The network was used as an information data base. If conflicting information was received, an employee would simply ask someone to set the record straight and usually someone who knew the answer would respond with accurate data. If that did not occur, then views would be expressed until accuracy was determined.

6. Like the national voting polls over the national television network, voting polls were taken over the computer network as to those who were for or against the merger. 
7. When voting did commence, the network was used to communicate the disposition of the vote for each individual geographic location.

8. Since it was difficult to stop the communications of front line employees over the wires, the Vice President of Labor Relations decided that he too would communicate over the network. He essentially joined the grass roots employee coalition.

The personal-therapeutic and the political-economic models of change best summarize the grass roots movement. The fifth conclusion regarding the change action as it relates to the models of organizational change is visualized in Figure 47. The darkened cells represent those models of change that best explain why the grass roots movement occurred at $P S A$, which further articulates the change event. The undarkened cells represent those models of change that may have some explanatory power, but far less than the two models that are dominant.

Overall Conclusions

Now that each of the five individual change actions have been summarized and conclusions have been drawn as to their relationships to the specific models of change, a collective view can now be discussed as it pertains to the big picture of this case study and the specific research questions that the study was chartered to address.

This section of Chapter VI focuses on the four research questions that need to be addressed in this case 


\section{Dimensions of Planned Organizational Change}

\begin{tabular}{|c|c|c|c|c|c|c|}
\hline & & 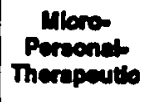 & 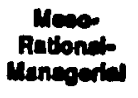 & 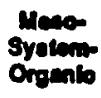 & $\begin{array}{l}\text { Meoror } \\
\text { culturat } \\
\text { symbolto }\end{array}$ & 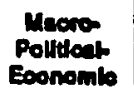 \\
\hline $\begin{array}{l}\text { H } \\
\text { A }\end{array}$ & $\begin{array}{l}\text { Internal Mochanisms } \\
\text { for Articulating } \\
\text { Change } \\
\text { (PSA Nows and } \\
\text { PSA USAir Merger } \\
\text { Update) }\end{array}$ & & & & & \\
\hline$E$ & $\begin{array}{l}\text { External Mechanisms } \\
\text { tor Articulating } \\
\text { Change }\end{array}$ & & & & & \\
\hline E & (Newspaper Anticles) & & & & & \\
\hline$E$ & $\begin{array}{c}\text { The } \\
\text { Programmatic } \\
\text { Processes } \\
\text { (Training) }\end{array}$ & & & & & \\
\hline C & $\begin{array}{l}\text { Impacting } \\
\text { Leader } \\
\text { Actions } \\
\text { (Russell Ray, } \\
\text { Presidenil) }\end{array}$ & & & & & \\
\hline 0 & $\begin{array}{c}\text { The } \\
\text { Grass Roote } \\
\text { Movement }\end{array}$ & & & & & - \\
\hline
\end{tabular}

Figure 47. Personal-therapeutic and political-economic models of change are predominant from the viewing the grass roots movement. 
study so that the researcher can effectively accomplish the purpose of the research.

The answer to the first question is embodied in the the context of this chapter but can now be summarized. The first research question asked: "What specific actions were taken by PSA to deliberately facilitate the change, who initiated these actions, and why?"

The actions that were taken to facilitate the change were internal mechanisms for articulating change, external mechanisms for articulating change, the programmatic processes, the impacting leader actions and the grass roots movement. These actions were fully initiated by President and Chief Operating officer Russell Ray and the change strategy team, consisting of selected PSA executives including this researcher. The PSA USAir Merger Update was specifically initiated by change strategy team member, Morton Rible, because the team agreed that consistent and honest communication in written form must take place during the transition period of the merger. The newspaper article collection and distribution was initiated by change strategy team member, Bill Hastings, because the team agreed that the media offered another view of the change that may be helpful to the employees. The programmatic processes were initiated by this researcher, and the team agreed that a structured intervention would significantly complement the other measures which were taken to ensure that productivity did 
not plummet. The impacting leader actions were initiated by Russell Ray, and he team fully concurred that his actions were critical in his role as President and Chief Operating officer of PSA. The grass roots movement was initiated by the employees of PSA and USAir, and from this movement messages were collected by this researcher for the purpose of providing still another lens from which to view the change event.

The second research question is: "To what extent does this case exemplify and operationalize the five primary models of organizational change?"

Figure 48 is the heart of this case study. Some observations that can be concluded from viewing this figure are:

1. People viewed the merger differently because in part there were five distinct change activities that helped them view the process through five different pairs of eyes.

2. The systems-organic and the political-economic models were the most common frames for viewing the change. The systems-organic model explained three of the five change events: the internal mechanisms for articulating change, the programmatic processes and the impacting leader actions. This demonstrates the overall dominance of this model. Additionally, the political-economic model explains three of the five change events: the internal mechanisms for articulating change, the external 
Dimensions of Planned Organizatlonal Change

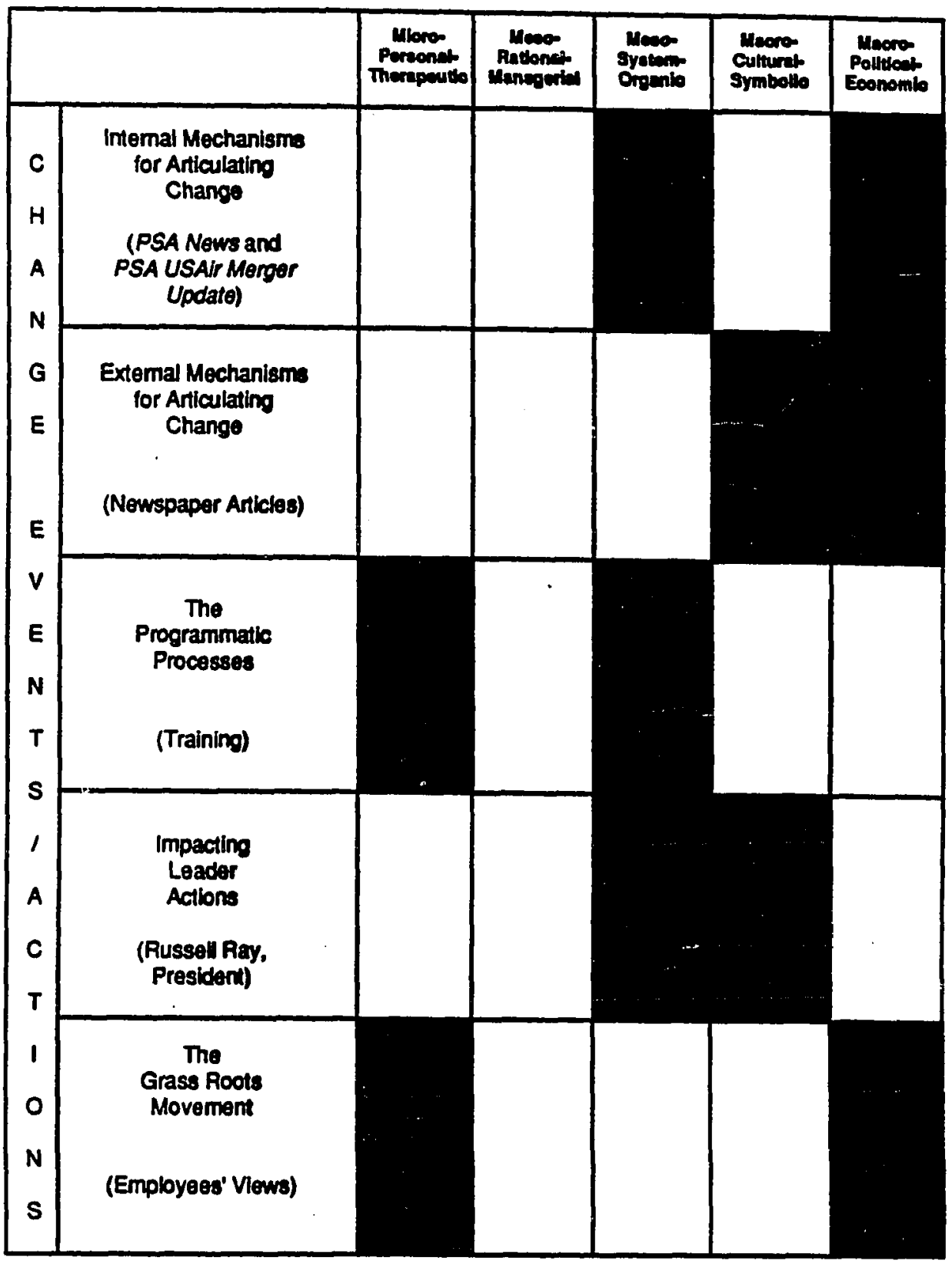

Figure 48. The extent to which the case study exemplifies and operationalizes the five primary models of organizational change. 
mechanisms for articulating change and the grass roots movement. This, too, demonstrates the overall dominance of this model.

3. The rational-managerial model of change did not prevail as a model which explained the change event. In fact, in none of the five actions did this model provide an explanation.

4. Even though the change strategy was designed to provide different lenses for viewing the change, the change strategy team had no idea which lenses would emerge as dominant. Based upon this point, the change strategy team members did not meet their objective as fully as they had wanted since none of the five change actions had the rational-managerial as a dominant pair of eyes. The intent of the change strategy team was to build a plan which would incorporate the explanations of all change models.

5. The fact that a change strategy team was created to facilitate the change determined ahead of time that the systems-organic model would be a dominant model. The thinking that was required to even initiate a change strategy team comes from a systems-organic domain, and hence the systems-organic explanation stemmed from the vision of Russell Ray to create the team.

The third research question is: "To what extent was the implementation of this organizational change skewed toward one single paradigm of change or to a more 
multidimensional paradigm of change?"

The answer to this question is that neither one single paradigm of change nor a fully multidimensional paradigm of change explains the merger of PSA by USAir. The paradigm is, however, more multidimensional than it is singular.

The multidimensional aspects of the explanation of the change are evident in that the personal-therapeutic model explained two of the five change actions, the systems-organic model explained three of the five change actions, the cultural-symbolic model explained two of the five change actions and the political-economic model explained three of the five change actions.

The implementation of this organizational change was not skewed to only one paradigm of change. If that were so, one model would have had to have explained all five change actions. This did not occur. As a result, the single frame answer has to be rejected.

The emphasis of the explanation was multidimensional but not fully multidimensional. The rational-managerial model was not used to explain any change action. The other four models, however, did provide explanations in two or three of the change actions.

Overall, the systems-organic model emerges as dominant for two key reasons. First, Russell Ray had a systems-organic mindset and as a result he initiated and created the change strategy team. Second, once created, 
the change strategy team was naturally inclined to do systems-organic activities both because of the mission passed down by Ray and the mindsets of its members (including this researcher). Systems-organic activities are what change strategy teams do. It is inherent to their function. If they did not do systems-organic activities, they would be dysfunctional.

The last research question: "What conclusions can be drawn so that scholars and practitioners of organizational change can gain from the thick description of this case study and its relationship to the predominant change models?"

In addition to the conclusions offered, scholars and practitioners should draw some of their own specific conclusions after reading this case. That point is important because this researcher hopes that the readers would take responsibility to generate ideas and issues that directly relate to their change events that are not known by the researcher. The reader is asked to take responsibility by seeking applications from the qualitative data presented.

Along with that notion, the researcher believes that there are many conclusions that can be drawn.

First and foremost, we as scholars and practitioners, must change our thinking about how we think about change. As the analysis of this study reveals, change is a complex process which requires multidimensional views in order to 
better facilitate understanding on the part of the organization's members. The tendency of some organizations might be to initiate a change strategy plan, as in the case of PSA during the acquisition period. The tendency of most organizations, however, is to focus on the end result, not a change strategy plan. Typically, the attention that a change usually receives is based upon all the ways in which the end result can be achieved, void _. - of how the change is facilitated while getting to the end result. Getting to the end result often becomes our framework instead of getting to the end result and facilitating the process along the way to the end result. second, change is multidimensional. The more singularly a change is viewed, the more myopic our vision is, thus shrinking our understanding. The more multidimensional a change is viewed the more broad our vision is, thus expanding our understanding. The fact that this case study was explained from the perspective of four of the five models of change supports the idea that change is multidimensional. If only the internal mechanisms for articulating the change were used to describe and explain the change that was happening, for example, clearly a narrow view of the change would have resulted. Combining the description and explanation of the change from the lens of other models added dimensions to the change.

Third, a multidimensional view of change does not 
happen coincidentally. It happens through a deliberate effort to blend change theory and organizational change strategy. It happened in this case study by this researcher having knowledge of the models of organizational change and then transferring that knowledge into the development of a change strategy that would deliberately incorporate multiple explanations of the change through the use of multiple change actions. Fourth, one way to determine whether or not a change was successful is to pay attention to the degree to which resistance occurs and how long it takes until the change is accepted. This can be done only if an effective change strategy is in place that encompasses feedback loops. The grass roots movement is an example in this study of one such feedback loop. This principle has value because of the belief that resistance to change can be correlated with declines in productivity and acceptance to change can be correlated with stability or inclines in productivity.

Fifth, the people involved with the change strategy team influenced the way in which the change was facilitated. The tendency of those involved to facilitate change from a systems-organic and political-economic lens impacted the outcome.

Sixth, even though this change is viewed as successful (the merger did take place), the specific actions taken cannot necessarily be replicated in any organization, because PSA tends to be a systems-organic 
and political-economic culture. In essence, the darkened boxes reflect the culture of PSA as well as the outcome of the change.

Last, more qualitative research is needed in the area of organizational change in action. Taking a slice of time and holding it still so that is can be thickly described contributes to the literature if only to see change theory come alive. This case study is an example of change theory in action.

\section{Strengths}

The strength of this investigation lies in the fact that it puts the various elements of scholars' modeis of organizational change to the test in the life of one change event. It answers the questions: "Can these change theories and models be applied in the life of a real change event in the corporate arena, and if so, how was it operationalized?" This study builds upon the work of other researchers by describing how one change event exemplifies each of the major components in the various change models. That is, the models are legitimized by the fact that they are being operationalized in an organization that experienced a major change.

This investigation also contributes to our understanding of organizational change by offering a more indepth description of how organizational change can be facilitated. The study enables researchers and practitioners to examine the actions and behaviors of one 
organization which was engaged in a transformation that merged one company into another one. Iike a cocoon that changes to a butterfly, the social realities of that existence change. In providing a thorough, descriptive analysis of USAir's acquisition of Pacific Southwest Airlines, this study moves both scholars and practitioners to an increased understanding of the nature of organizational change.

The fact that this researcher was a participant observer, a member of the change strategy team, an employee and an officer of PSA, and the investigator is a strength to this study. Immersing oneself into the very fiber of the change event is at the core of the ethnographic research practice.

The essential strength of this investigation then is that it provides researchers with an operational model of a theoretical construct. This is valuable because it shows that while the concept of organizational change is sometimes difficult to grasp and often appears to be ideal, organizational change models can be put into practice. Thus, for scholars interested in expanding the field of organizational change as an academic discipline, the models presented in this study serve as a starting point for conducting future investigations that examine other organizational changes in action. For practitioners, this study is rich with examples that can be used as tools in developing different processes of 
organizational change. If, as the concept suggests, educating members of the organization is a key ingredient in how social realities are constructed and reconstructed, then future facilitators of change must have a variety of indepth examples that show how education can be used to facilitate organizational change.

Weaknesses

Perhaps the most significant weakness in this study is that the researcher was unable to observe the organizational change under investigation for a long period of time, or at least until the integration of the two airlines was complete. Obviously, in the spirit of true participant observation, it would have been optimal to follow the change event through the year 1987 and on into 1988. Assuming that would have been possible, the time and expense involved in such an extended method was beyond the scope of the resources available to this investigator.

Another weakness is the study stems from the fact that the observations made during this organizational change are vulnerable to certain elements of distortion. With the exception of first hand observations through long term residence in the organization, there is no simple way to account for the inherent, subjective views that seep into research of this nature.

Still another weakness is the researcher's own selection of material to be presented in this study. That 
selection is another basis for some distortion. As the research progressed it became increasingly difficult for the researcher to remain untouched by the events that were happening. As is their natural tendency, the people of PSA were extremely committed to the organization and had a way of expressing that commitment in a meaningful and caring way. Since the researcher was a part of what each employee was feeling, it influenced how the study is presented, the data collected and the analysis of the data. Unfortunately, it is difficult to avoid this kind of human limitation.

A distortion also emerges in this study as a result of the researcher's biases about organizational change. It may be argued that a researcher seeking to uncover a given specified concept such as organizational change in action could create a self-fulfilling prophecy in which she constructs a distorted image of the event that is consistent with the concept under investigation. However, this argument is weakened as it relates to this study by several factors. First, the researcher set out to develop a line of research that sought to examine many organizations in the midst of change. Through an initial examination of these organizations, it became apparent that one emerged as not only the best example of organizational change in action, but indeed as a potentially true example of organizational change in action. Thus, rather than entering this research with an 
a priori assumption that this organizational change would be more multidimensional in nature than the next, the researcher critically compared what was actually happening with the theoretical constructs that had been internalized in her education.

\section{Future Research}

With the strengths and weaknesses of this study in mind, there are several areas in which future research is warranted. While this study presents a starting point for conducting qualitative investigations that examine organizational change in action, the models offered should be applied in their entirety to other change events. This will enable future researchers to describe in more detail if and how the models can be operationalized. Obviously, a concept as broadly based as organizational change will not be operationalized in the same manner by different organizations. Therefore, future studies that focus on how the concept is being operationalized in other organizations would also serve to confirm or not confirm the utility of the models as descriptions of the nature of organizational change.

Methodologically, future researchers could build upon this work through participant observation for an extended period in an organization where organizational change is happening. Moreover, these researchers should attempt to examine organizational change in as many different contexts as possible. By investigating events in a 
variety of contexts over time, these researchers would be able to determine the consistency with which these events demonstrate organizational change in action and whether or not such consistency is essential to being a facilitator of change.

An argument could be made for investigating particular aspects (e.g. power and politics, symbolic leadership, organizational systems) of organizational change more thoroughly. However, this approach may be premature given that the frameworks have yet to receive widespread validation so that the theories can be translated in action. If researchers and practitioners are going to conduct studies that truly further our understanding of organizational change, they must engage in broad based studies that transcend singular views of change. Thus, future studies that incorporate all of the models of organizational change and examine the concept holistically will contribute to a new and growing paradigm that will enhance our understanding of organizational change in action.

\section{Concluding Remarks}

Along with modern life has come the change revolution. The magnitude and amount of change that is all around us, and within us, often create difficulties among organizations, communities and even countries. Change in organizations is common and constant. From an organizational perspective, the idea of seeing, creating 
and facilitating change is one of the most difficult, perplexing and challenging opportunities faced by organizational theorists, managers and leaders.

There is a change crisis facing American business and the world today. It is, therefore, vital that we as scholars, practitioners, managers and leaders confront the problems associated with narrow views or single models of change and develop a new understanding of change as a constant, fluid, ongoing, dynamic, always present and evolutionary process which moves individuals and organizations.

It is the hope of this researcher that the story of USAir's acquisition of Pacific Southwest Airlines will inspire readers to examine the potential for facilitating change for themselves and their organizations and encourage them to realize that intended, real change in organizations does not happen by coincidence. It happens by members of the organization taking initiative to develop comprehensive change strategies that attend to people and, in the process, keep their organizations productive. 


\section{REFERENCES}

Abernathy, W. J. (1981, September/October). The new industrial competition. Harvard Business Review, pp. $42-58$.

Alderfer, C. P. (1977). Organization development. Annual Review of Psychology, 28, 197-223.

Allison, G. T. (1971). Essence of decision: Explaining the Cuban missile crisis. Boston: Little, Brown, and Co.

Allison, G. T. (1984). Public and private administrative leadership: Are they fundamentally alike in all unimportant respects? In T. J. Sergiovanni \& J. E. Corbally (Eds.), Leadership and organizational culture (pp. 214-239). Chicago: University of Chicago Press.

Argyris, C., \& Schon, D. (1978). Organizing learning: A theory of action perspective. Reading, MA: AddisonWesley.

Bantz, C. R. (1983). Naturalistic research tradition. In L. L. Putnam \& M. E. Pacanowsky (eds.), Communication and organizations (pp. 55-66). Beverly Hills, CA: Sage.

Bastien, D. T. (1987, January). Common patterns of behavior and communication in corporate mergers and acquisitions. Human Resource Management, pp. 17-33.

Bennis, W. (1984). Transformative power and leadership. In T. J. Sergiovanni \& J. E. Corbally (Eds.), Leadership and organizational culture (pp. 64-71). Chicago: University of Chicago Press.

Bennis, W., \& Nanus, B. (1985). Leaders: The strategies for taking charge. New Yor

Bensahel, J. G. (1981, September). Why employees should be involved in change. International Management, pp. 41-42.

Bertrand, K. (1987, February). When silence isn't golden. Business Marketing, pp. 62-69. 
Bloomquist, R. (1986). Action research on change in schools: The relationship between teacher morale/job satisfaction and organizational changes in a junior high school. New Hampshire University, Durham.

Bolman, L. G., \& Deal, T. (1984). Modern approaches to understanding and managing organizations. San Francisco: Jossey-Bass.

Bridges, W. (1988, October). Managing organizational transitions. Organizational Dynamics, pp. 36-47.

Burns, J. M. (1978) - Leadership. New York: Harper \& Row.

Burns, J. M. (1984). The power to lead: The crises of the American presidency. New York: Simon \& Schuster.

Child, J. (1972). Organizational structure, environment, and performance: The role of strategic choice. Sociology, 6. $1-22$.

Cole, R. (1982). Diffusion of participatory work structures in Japan, Sweden, and the United States. In P. Goodman, et al. (Eds.), Change in organizations (pp. 166-225). San Francisco: Jossey-Bass.

Deal, T. E., \& Kennedy, A. A. (1982). Corporate cultures: The rite and rituals of corporate life. Reading, MA: Addison-Wesley.

Feyerabend, P. (1975). Against method. London: Verso.

Foster, W. (1986). Paradigms and promises. Buffalo, NY: Prometheus Books.

Friedlander, F., \& Braun, L. D. (1974). Organization development. Annual Review of Psychology, 25, 313-341.

Geertz, C. (1973). The interpretation of cultures. New York: Basic Books.

Gerard, K. N. (1986, July). After the merger comes the bad part. Across the Board, pp. 50-54.

Goodman, P., et al. (Eds.) (1982). Change in organizations. San Francisco: Jossey-Bass.

Graham, R. J. (1981, March). Understanding the benefits of poor communications. Interfaces, pp. 80-82. 
Havelock, R. G. (1973). The change agent's guide to innovation in education. Englewood Cliffs, $\mathrm{NJ}$ : Educational Technology Publications.

Howard, E. (1986, February). Merger communication: What can you do? Communication World, pp. 29-30.

Kanter, R. M. (1983). The change masters. New York: Simon \& Schuster.

Kanter, R. M. (1983). Power failure in management circuits. In E. G. C. Collins (Ed.), Executive success: Making it in management (pp. 249-266). New York: Wiley.

Katz, D., \& Kahn, R. L. (1976). The social psychology of organizations. New York: John Wiley.

Kotter, J. P., \& Schlesinger, I. A. (1978, March/April). Choosing strategies for change. Harvard Business Review, pp. 106-114.

Levinson, H., \& Rosenthal, S. (1984) . CEO: Corporate leadership in action. New York: Basic Books.

Lewin, F. (1951). Field theory in social science. New York: Harper.

Licata, B. J. (1984). New technology implementation and use: Workers' attitudes and behaviors. Presented at the American Society for Training and Development Conference, Dallas, TX, May 20-25.

Lowan, R. I. (1980). Constructing relationships from which to change organizations. Paper presented at the Annual Convention of the American Psychological Association, Montreal, Quebec, Canada, September 1-5.

Lund, R. T., \& Hansen, J. A. (1986). Keeping America at work. New York: Wiley.

Mead, M. (1959). Apprenticeship under Boas. In W. Goldschmidt (Ed.), The anthropology of Frans Boas, memoir 89 (pp. 29-45). Washington, DC: American Anthropological Association.

Merrel1, D. W. (1986). The impact of restructuring on employees. Journal of Buyouts and Acquisitions, 4 (1), pp. $60-62$.

Pelto, P. J. (1973). Anthropological research, the structure of inguiry. New York: Harper \& Row. 
Peters, T. J., \& Waterman, R. H. (1982). In search of excellence. New York: Harper \& Row.

Pondy, L. R. (1978). Leadership is a language game. In M. W. McCall \& M. M. Lombardo (Eds.), Leadership: Where else Can we go? Durham, NC: Duke University Press.

Price, P. (1985). Managing people problems in deals that don't close. Journal of Buyouts and Acquisitions, 3 (7), pp. 35-38.

Putnam, L. (1982). Paradigms for organizational communication research: An overview and synthesis. Western Journal of Speech Communication, 46, 192-206.

Quinn, L. R = (1987, March). Making a mess out of merging. Executive FinanciaI Woman, pp. 7-15.

Reich, R. B. (1983). The next American frontier. New York: Times Books.

Rost, J. C. (1982). The politics of leadership. Paper presented at the Annual Meeting of the American Research Association, New York, NY.

Ruch, R. S., \& Goodman, R. (1983). Image at the top: Crisis and renaissance in corporate leadership. New York: Free Press.

Sanday, P. R. (1983). The ethnographic paradigms. In J. Van Maanan (Ed.), Qualitative methodology (pp. 19-36). Beverly Hills, CA: Sage.

Sergiovanni, T. J. (1984). Leadership as cultural expression. In T. J. Sergiovanni \& J. E. Corbally (Eds.), Leadership and organizational culture (pp. 105-114). Chicago: University of Chicago Press.

Soukup, P., \& Boone, M. (1983). Negotiation through power, ideology and technology in the local development of the Catholic Telecommunications Network of America. Paper presented at the Annual Meeting of the International Communications Association, Dallas, TX, May 26-30.

Staff. (1987, March). Understanding the human side of mergers. Executive Financial Woman, pp. 25-30.

Thorrow, I. (1981). Revitalizing the U.S. economy. California Management Review. 
Trice, H. M. (1984). Rites and ceremonials in organizational culture. In S. B. Bacharach \& S. M. Mitchell (Eds.), Perspectives on organizational sociology: Theory and research (Vol. 4). Greenwich, CT: JAI Press.

Ulrich, D. O. (1987). Competitive advantage through organizational capability: The central role of human resource management. Working paper, University of Michigan.

Van Maanan, J. (1983). The facts of fiction in organizational ethnography. In J. Van Maanan (Ed.), Qualitative methodology (pp. 37-55). Beverly Hills, CA: Sage.

Ward, B. (1987, July). Managing change. Sky Magazine.

Whorff, B. I. (1979) . Language, thought and reality. Cambridge, MA: Addison-Wesley.

Wilson, S. (1983). The use of ethnographic techniques in educational research. Perspectives on Case Study: Ethnography, 5, 1-22.

Wolcott, H. (1983). Criteria for an ethnographic approach to research in schools. Perspectives on Case Study: Ethnography, 5, 23-56.

Zald, M. (1968). Organizational change: The political economy approach. Paper presented at the Annual Meeting of the Southern Sociological Society, Atlanta, GA.

Zald, M. (1970). Political economy: A framework for comparative analysis. In $M$. Zald (Ed.), Power in organizations (pp. 221-261). Nashville, TN: Vanderbilt University Press.

Zaleznik, A. (1983). Managers and leaders: Are they different? In G. C. Collins (Ed.), Executive success: Making it in management (pp. 123-139). New York: Wiley. 